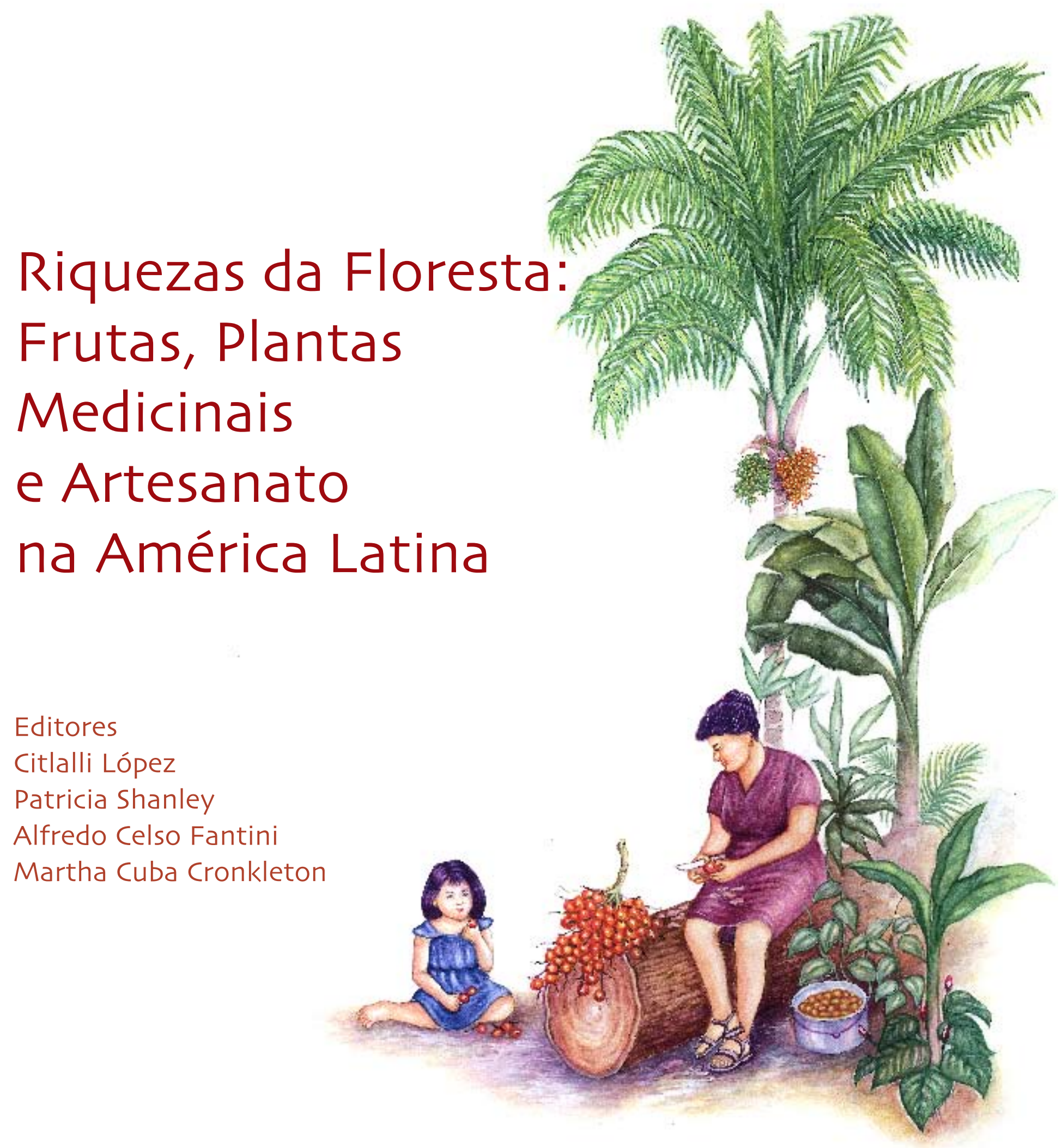


O Centro de Pesquisa Florestal Internacional (CIFOR, sigla em inglês) é uma organização internacional de pesquisa florestal, criada em 1993 em resposta às preocupações globais acerca das consequências sociais, ambientais e econômicas da perda e degradação das florestas. 0 CIFOR se dedica à formulação de políticas e de tecnologias para o uso e gestão sustentável de florestas, e a melhoria do bem-estar dos habitantes dos países sub-desenvolvidos cujos povos dependem das florestas tropicais. O CIFOR é um dos 15 centros de pesquisa do Grupo Consultivo em Pesquisa Agrícola Internacional (CGIAR). A sede do CIFOR está localizada em Bogor, na Indonésia. O Centro conta também com escritórios regionais no Brasil, Burkina Faso, Camarões e Zimbábue, e trabalha em mais de 30 países do mundo. 


\author{
Riquezas da Floresta: \\ Frutas, Plantas Medicinais \\ e Artesanato na América Latina
}





\title{
Riquezas da Floresta: Frutas, Plantas Medicinais e Artesanato na América Latina
}

\author{
Editores \\ Citlalli López \\ Patricia Shanley \\ Alfredo Celso Fantini \\ Martha Cuba Cronkleton
}
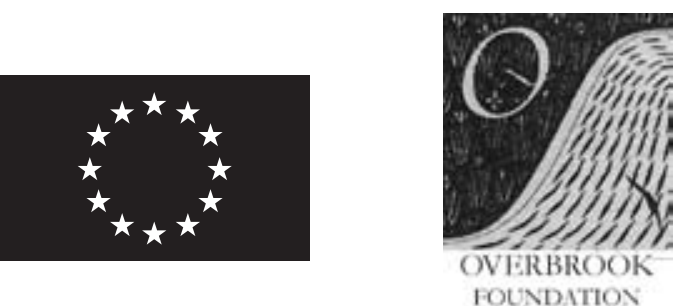
Tradução de Alfredo Celso Fantini

Titulo Original: Riches of the forest: fruits, oils, remedies and handicrafts in Latin America

López, C., Shanley, P. e Fantini, A. (Editores) 2004. Riches of the forest: fruits, oils, remedies and handicrafts in Latin America. CIFOR / DFID / EC / Overbrook Foundation. Indonésia.

Revisor científico: Miguel N. Alexiades

Revisão de texto em português: Alfredo C. Fantini e Juliana P. Alves

Iustração dos estudos de caso e da capa: April Mansyah

(exceto ilustrasões do caso Wareque, ilustrado por Dadi Sungkowo)

Desenhos botânicos: Silvia Cordeiro

(exceto Sabal yapa e Pouteria sapota ilustrados por Ishak Syamsudin e Ibervillea sonorae por Alifie Rojas)

Lay-out: Eko Prianto e Yani Saloh

Diagramação:

(C) 2008 por CIFOR - Centro para Pesquisa Florestal Internacional

Todos os direitos reservados. Publicado em 2008

Impresso em SMK Grafika Desa Putera

ISBN 979-24-4623-0

Endereso:

Centro de Pesquisa Florestal Internacional

Jalan CIFOR, Situ Gede, Sindang Barang

Bogor Barat 16680, Indonesia

Tel.: +62 (251) 622-622; FAX: +62 (251) 622100

Email: cifor@cgiar.org

Website: www.cifor.cgiar.org 


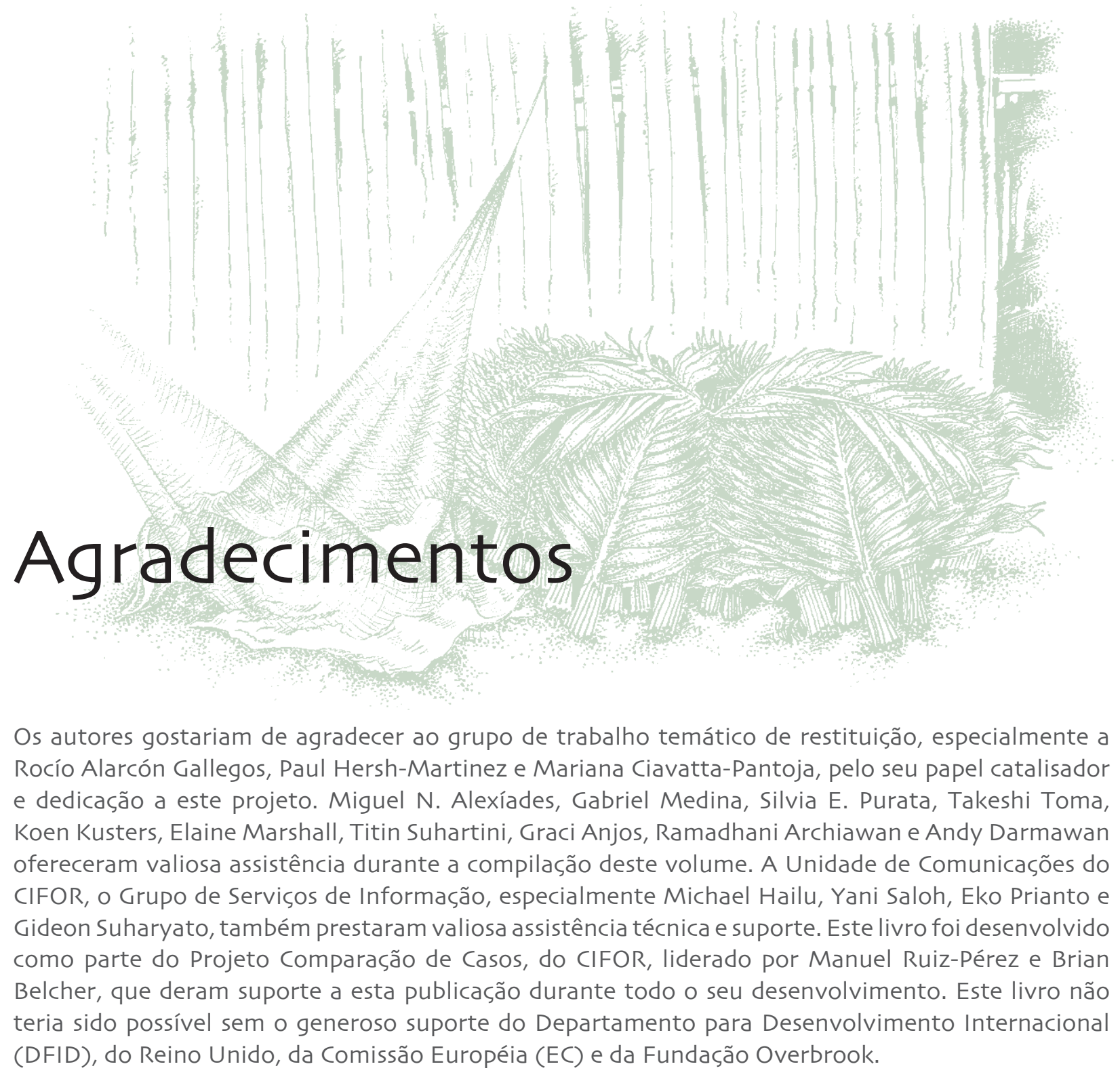




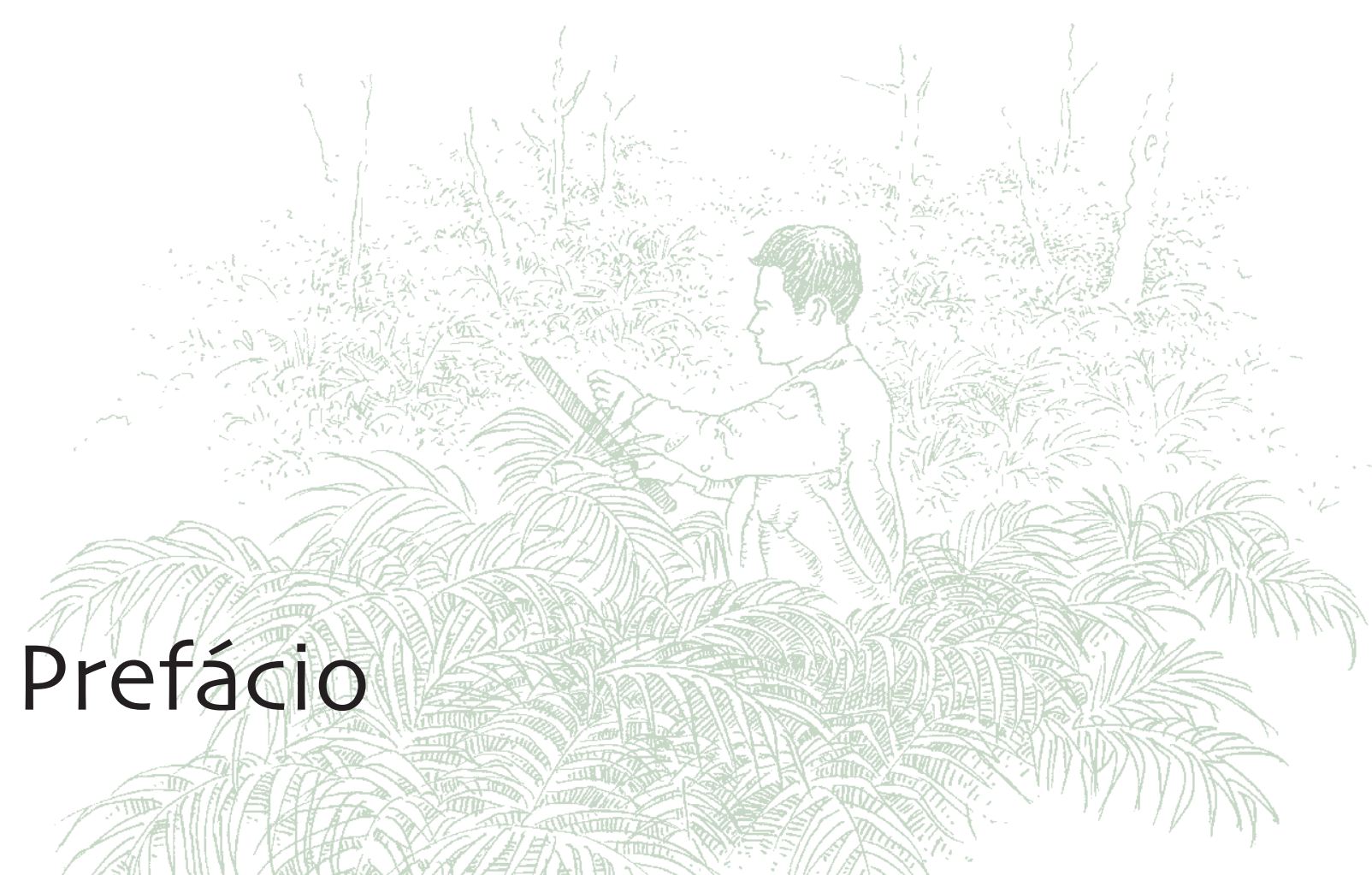

Os humanos sempre foram dependentes das plantas para a sua sobrevivência bem como para o seu bem-estar físico, estético e espiritual, e as ligasões entrelas pessoas e as plantas se tornaram crescentemente vastas e complexas. Muitos produtos vegetais ainda são consumidos e trocados fora do sistema monetário, próximos das florestas onde os mesmos produtos são coletados ou produzidos. Outros produtos, entretanto, são transformados de tal forma que se tornam irreconhecíveis e transportados para o outro lado do mundo, gerando milhões de dólares em moeda estrangeira e criando considerável número de empregos entre coletadores, processadores, comerciantes e revendedores. Essa tendência, por outro lado, reflete um processo histórico fundamental: as crescentes interconexões - econômicas, sociais e culturais - que ligam ambientes, povos e lugares totalmente diferentes.

Os capítulos deste livro narram ao mesmo tempo uma só e muitas histórias. Acima de tudo, a mensagem mais importante é que as florestas da América Latina contêm uma extraordinária diversidade de plantas e animais que, ao longo de milhares de anos, os humanos têm aprendido a explorar, apreciar, manipular e, em alguns casos, promover, enquanto em outros - tristemente destruir. Esta diversidade continua a manter a promessa de desenvolvimento social, embora não sem desafios. Um dos muitos temas deste livro ressalta a engenhosidade e a adaptabilidade humanas. Os produtos florestais não-madeireiros têm servido historicamente como redes de proteção para os 
agricultores e extratores que os coletam e vendem e, como tais, são parte de sistemas complexos de manejo e de respostas a flutuasões ambientais, políticas e econômicas.

A demanda internacional por produtos florestais da América Latina, por exemplo, tem historicamente sofrido ciclos de explosão e declínio. A explosão da demanda tem tipicamente seguido a descoberta de um produto florestal e sua posterior integrasão ao mercado mundial. Por sua vez, essa situaşão às vezes tem levado ao desaparecimento do produto ou da planta, através da superexploração ou substituição por uma alternativa mais abundante ou barata. Outro tema das narrativas deste volume diz respeito à história social, política e econômica dos trópicos latino-americanos, como revelada através das histórias sobre os produtos das plantas da floresta e os povos que os coletam e vendem. Ainda outros temas se relacionam à maneira como a mudança do destino de diferentes plantas da floresta está ligada à mudança do destino de diferentes grupos de pessoas. Qualquer mudanşa, seja em termos de oferta, demanda, ou qualquer dos seus fatores condicionantes, está ligada a alteracões na eqüidade entre os diferentes envolvidos ao longo da cadeia de produção.

Os leitores deste livro podem, então, tirar algumas lições importantes - advertências e inspiracões - dos produtos e povos retratados nestas páginas e das curiosidades descritas nos estudos de caso individuais. Acima de tudo, os leitores podem admirar e ponderar as maneiras com que as vidas e fatos de uma miríade de pessoas, plantas e lugares estão ligados pelos produtos da floresta e por aqueles que os coletam, processam, transportam e consomem.

\section{Miguel N. Alexiades}

Departamento de Antropologia

Universidade de Kent

Canterbury, U.K. 


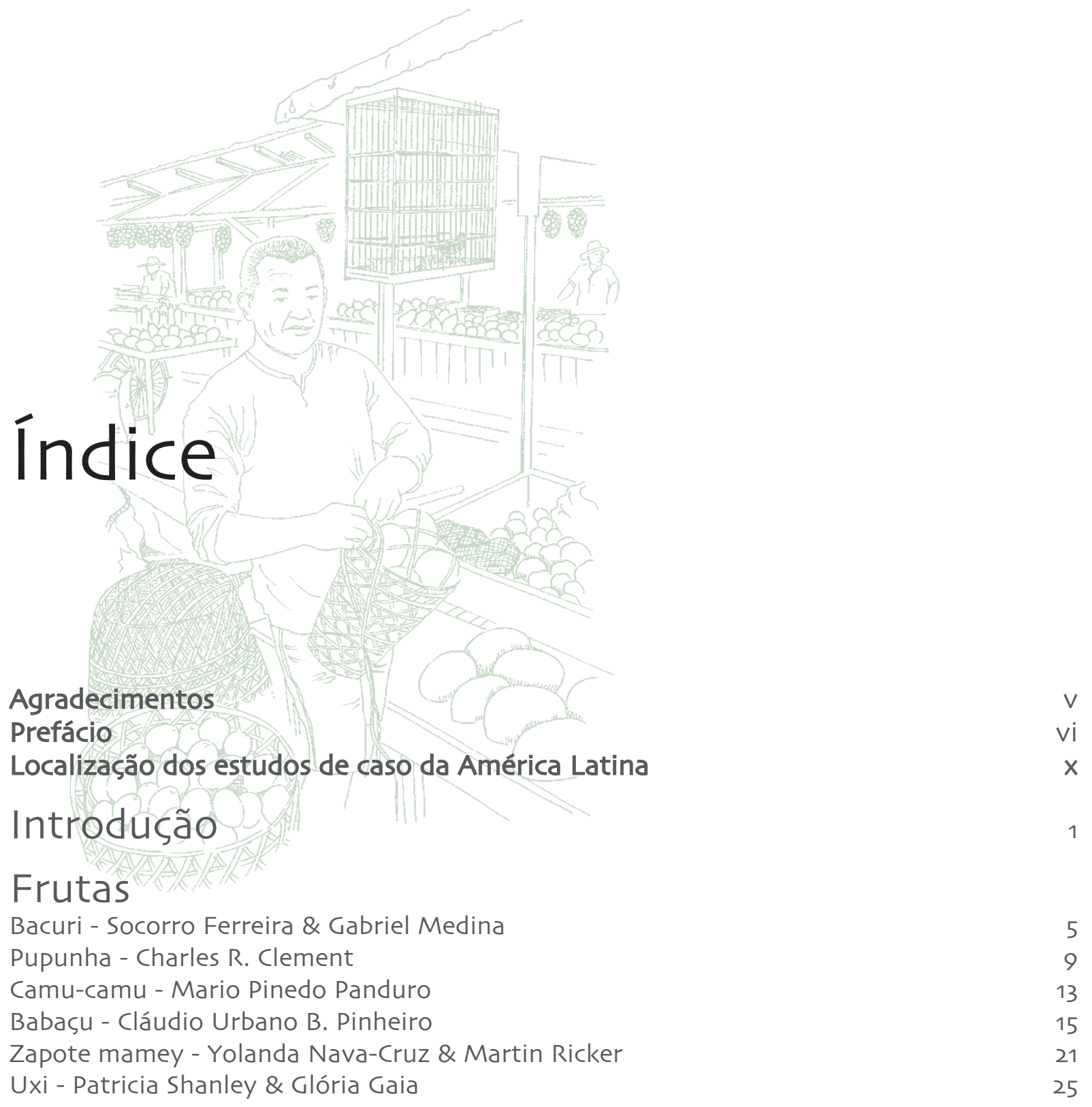




\section{Folhas}

Espinheira-santa, folhas medicinais - Marianne C. Scheffer 29

Palmeira camedor, planta ornamental / folhas decorativas - César Carrillo Trueba 33

Fibra toquilla, chapéu panamá - Rocío Alarcón Gallegos 37

Fibra Jipijapá, artesanato - Erik Arancibia \& Fausto López 41

Fibra de pita, bordados - Fabrice Edouard $\quad 45$

Carqueja, folhas medicinais - Walter Steenbock 49

Palmeira de guano, folhas para telhados - Javier Caballero, María Teresa Pulido

\& Andrea Martinez-Ballesté

\section{Sementes, Raízes e Brotos}

Pimenta-da-Jamaica - Miguel Angel Martínez Alfaro,

Virginia Evangelista Oliva, Myrna Mendoza Cruz, Cristina Mapes

\& Francisco Basurto Peña

Fáfia, ginseng brasileiro - Cirino Corrêa Júnior \& Lin Chau Ming 61

Ipeca, raiz medicinal - Rafael A. Ocampo Sánchez 65

Palmito - Alfredo Celso Fantini $\quad 69$

Andiroba, óleo medicinal - Patricia Shanley 73

\section{Casca e Madeira}

Alebrijes, esculturas - Silvia E. Purata, Berry J. Brosi \& Michael Chibnik 77

Unha-de-gato, cipó medicinal - Wil de Jong \& Walter Nalvarte 81

Amate, papel de casca de árvore - Citlalli López $\quad 85$

\section{Exsudatos}

Resina de pínus - Ynocente Betancourt Figueras \& Maria Josefa Villalba Fonte 89

Linalol, artesanato / óleo essencial - Paul Hersch-Martínez 93

Seringa, couro vegetal - Mariana Ciavatta Pantoja 97

Conclusões: Licões aprendidas 101

Referências 109

Glossário $\quad 122$

Detalhes do contato com os autores 131

Fonte do material usado para as ilustrações 138 


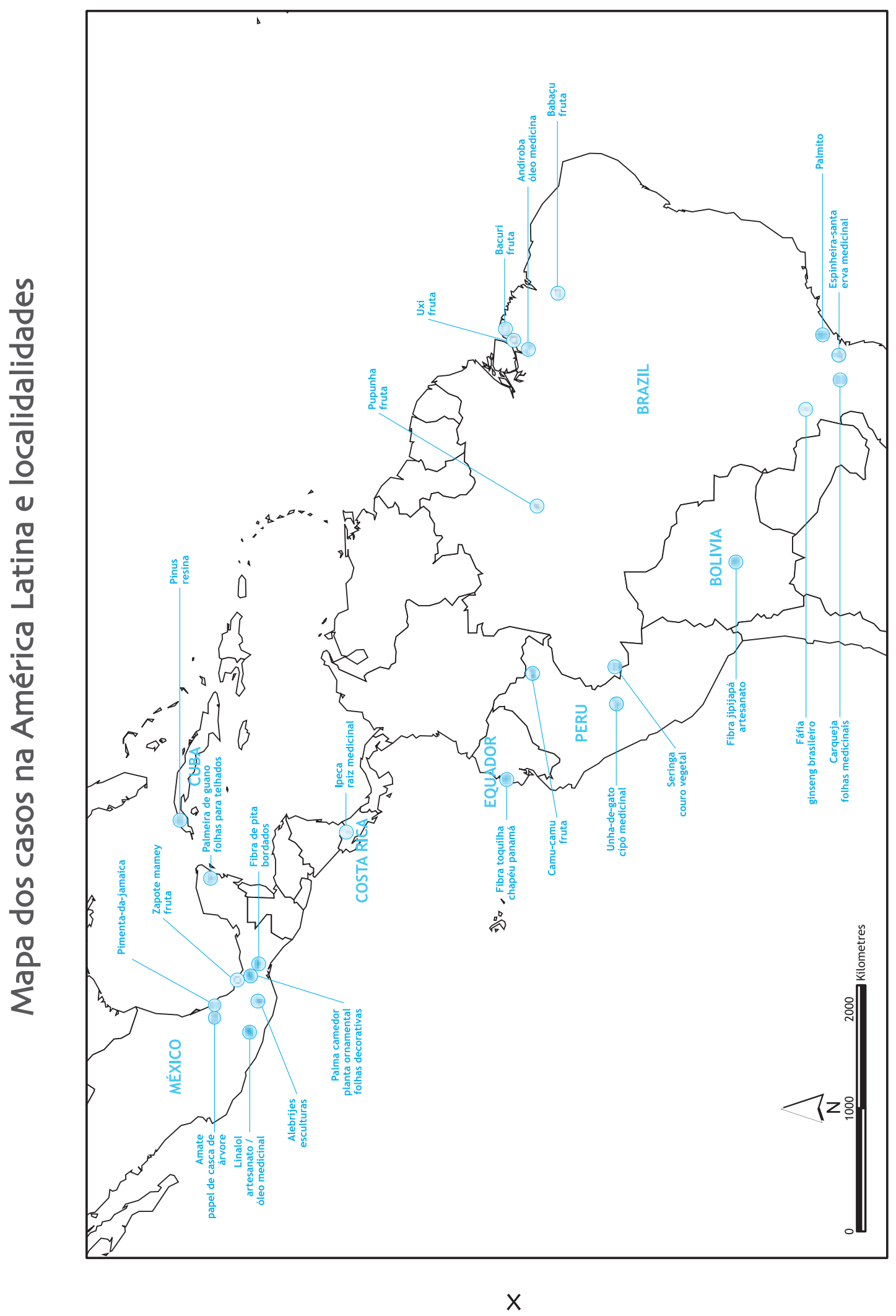




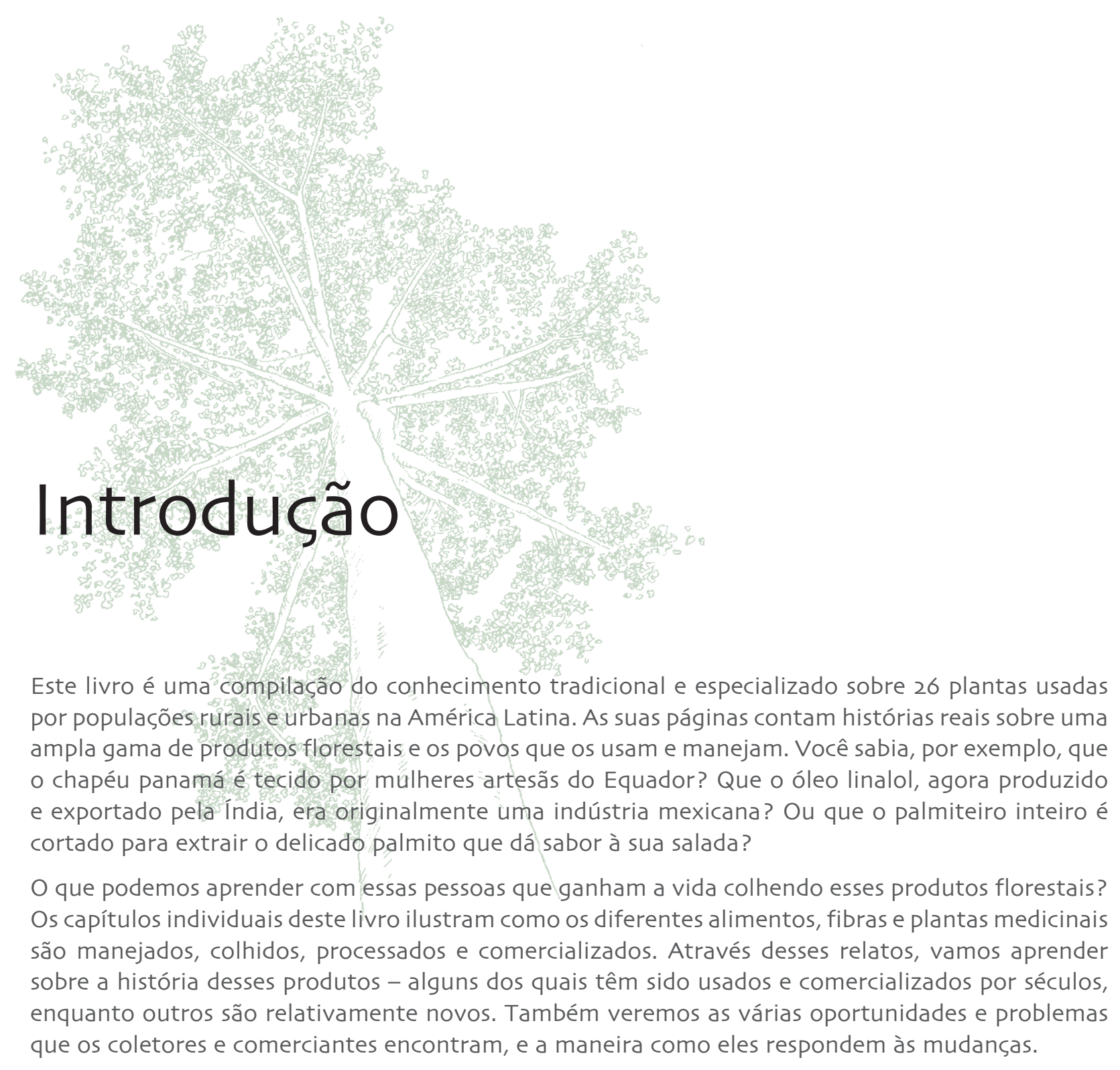

\section{Auges e declínios: Ciclos históricos do comércio de produtos florestais}

A história dos habitantes da América Latina está intimamente ligada à história dos produtos florestais. Por séculos, um intenso intercâmbio comercial e cultural tem conectado as diferentes regiões das Américas. Na era pré-colombiana, os povos indígenas trocavam mercadorias como as frutas mamey 
e o papel amate, de casca de árvore. Entre os séculos XVI e XIX, os colonizadores europeus erradicaram muitas das redes de troca e costumes comerciais que uniam as pessoas às suas plantas e terra. Paradoxalmente, entretanto, à medida que as redes locais e regionais eram desarticuladas, o comércio global de plantas tropicais da América Latina floresceu. Baunilha, quinina e raízes medicinais de ipeca foram os primeiros produtos comercializados. Um amplo intercâmbio cultural é evidente hoje no uso e processamento de várias espécies. No México, por exemplo, a madeira de linalol, obtida de espécies do gênero Bursera, tem sido entalhada desde os tempos pré-hispânicos, mas a sua decoração incorporou uma combinaşão de técnicas mexicanas, espanholas e asiáticas.

Durante a era industrial, avansos tecnológicos envolvendo a mecanização, urbanização e transporte, permitiram uma ampliação do comércio de produtos florestais, lavando a sua extração ao auge em todo o mundo. A América Latina tornou-se uma fonte mundial de borracha, raízes de ipeca, látex de chicle, raízes de barbasco com propriedades inseticidas naturais e chapéu panamá. Essa explosão de interesse foi seguida pela moderna era do declínio do comércio de produtos florestais. Em meados do século $X X$, as florestas começaram a ser valorizadas principalmente por seus recursos madeiráveis e pelas fibras usadas na fabricação de papel. Mas, ao mesmo tempo, o interesse comercial e científico por outros produtos florestais decaiu. Os substitutos químicos e sintéticos se generalizaram:0 barbasco foi substituído pelo DDT, o chicle por borracha sintética e as fibras naturais por plásticos.

Mas, em nova reviravolta renasceu o interesse nos alimentos, artesanatos e medicamentos naturais, uma mudança que provocou um aumento no comércio de uma gama de produtos florestais. Vários dos casos descritos neste livro, como a unha-de-gato, o camu-camu, a borracha e o ginseng brasileiro ingressaram na economia mundial somente nas duas últimas décadas (Alexiades e Shanley 2004).

O recente aumento no interesse por esses produtos tem sido acompanhado pela atenção das agências de conservação e desenvolvimento. No comeşo da década de 1980, o reconhecimento das rápidas taxas de desmatamento e o renovado reconhecimento sobre as dificuldades enfrentadas pelas pessoas que vivem em áreas rurais despertou a atenção sobre os produtos florestais que não implicavam a exploração da madeira. Os especialistas nesses temas começaram a avaliar o papel comercial e de subsistência desses produtos e a compará-los com as possíveis rendas que geram o aproveitamento de madeira e outros usos da terra. A investigaşão tem possibilitado o aparecimento de uma nova onda de interesse no grupo de produtos chamados produtos florestais não-madeireiros (PFNMs), que inclui uma grande variedade de recursos florestais utilizados tanto propósito doméstico como comercial. Esse recente interesse proporcionou um aumento da consciência da sua importância para comunidades das florestas bem como das cidades. 
Durante os últimos 15 anos, organizacões governamentais e não-governamentais (ONGs) têm dedicado atenção e apoio a diferentes atividades relacionadas aos PFNMs com o propósito de melhorar os meios de vida das famílias que vivem nas florestas e nas suas proximidades. Algumas dessas iniciativas têm obtido êxito em atingir objetivos sociais, econômicas ou de conservação. Os resultados gerais, entretanto, têm sido mistos, em parte devido à grande diversidade de condicões e às diferentes circunstâncias sob as quais os recursos florestais são coletados, processados e comercializados. Além disso, o curto prazo de duração de muitos projetos não permite o aprofundamento no conhecimento necessário para uma grande gama de produtos tão complexos como os PFNMs e para a elaboração de intervencões efetivas.

\section{Compartilhando o conhecimento sobre produtos florestais}

Muitos pesquisadores tem estudado produto florestais em diferentes partes do mundo utilizando métodos de várias disciplinas, incluindo silvicultura, economia e antropologia. Embora esses estudos tenham aumentado o nosso conhecimento sobre os recursos florestais, eles também têm formulado importantes perguntas. Por causa da ampla variedade de métodos utilizados nesses estudos, entretanto, tem sido difícil comparálos e tirar conclusões gerais. Para resolver esse problema, um grupo de pesquisadores de vários países uniu esforsos para comparar e contrastar estudos de casos individuais. Este projeto conjunto de pesquisa, coordenado pelo Centro de Pesquisa Florestal Internacional (CIFOR), com financiamento principalmente do Departamento para o Desenvolvimento Internacional do Reino Unido (DFID), incluiu 61 casos de comercialização de produtos florestas da Ásia, África e América Latina. O CIFOR trabalhou com pequenos grupos e pesquisadores individuais que representavam 47 universidades, instituicõos de pesquisa governamentais e organizações não-governamentais de 27 países. Os pesquisadores, que incluíam ecologistas, engenheiros florestais, agrônomos e antropólogos, queriam aprofundar o conhecimento sobre a grande amplitude de condições que determinam se o comércio de PFNMs beneficia a população rural e permite a conservação das florestas e, se assim o faz, como isso acontece.

O CIFOR já publicou uma coleção de três volumes científicos com enfoque na Ásia, África e América Latina, intitulados Produtos Florestais, Meios de Vida e Conservação: Estudos de caso de sistemas de PFNMs. Mas os pesquisadores também tinham vontade de compartilhar o seu conhecimento sobre os produtos florestais com um público mais amplo, para além dos cientistas e instituições financiadoras das pesquisas, utilizando uma linguagem mais simples e um formato ilustrado e reduzido. Para atingir esse objetivo, nós produzimos outros três volumes complementares: Riquezas da floresta: Alimentos, especiarias, artesanato e resinas da Ásia; Riquezas da floresta: Para a saúde, a vida e o espírito na África e Riquezas da floresta: Frutas, remédios e artesanato na América Latina. 
O livro que você tem em suas mãos é um dos produtos do esforço colaborativo desses pesquisadores. Os 40 pesquisadores que participaram dos estudos de caso da América Latina explicam como um grupo de recursos florestais é coletado, processado e comercializado. Os consumidores geralmente vão aos mercados e lojas onde escolhem e compram alimentos, produtos para decoração ou produtos de beleza sem saber muito, ou mesmo nada, sobre a história desses produtos ou as pessoas envolvidas na sua coleta e venda. Este esforso vem em boa hora, num momento em que a cobertura florestal no mundo vem diminuindo de forma muito rápida, e as florestas que dela dependem têm que se adaptar à mudança também muito rapidamente.

\section{Os estudos de caso}

Este livro aborda 25 estudos de caso sobre plantas e animais da floresta. Os casos botânicos são apresentados de acordo com a parte principal da planta que é usada - fruta, casca, raiz ou madeira. Algumas vezes, uma planta tem múltiplos usos, ou diferentes culturas podem usar a mesma parte de uma planta de maneiras diferentes. Em cada caso, os autores descrevem as principais características do produto florestal, sua história, colheita e manejo, e como é processado e comercializado. Ao final de cada caso, o autor comenta brevemente as tendências e questões atuais sobre os recursos. O capítulo final traz uma revisão de temas comuns e lições que podem ser tiradas dos casos apresentados.

Nos casos apresentados, um asterisco (*) assinala palavras cuja definição pode ser encontrada no glossário ao final do livro. No início de cada caso, é apresentado o nome científico da planta estudada. Uma explicasão detalhada sobre o uso de nomes científicos também pode ser encontrada no glossário. 


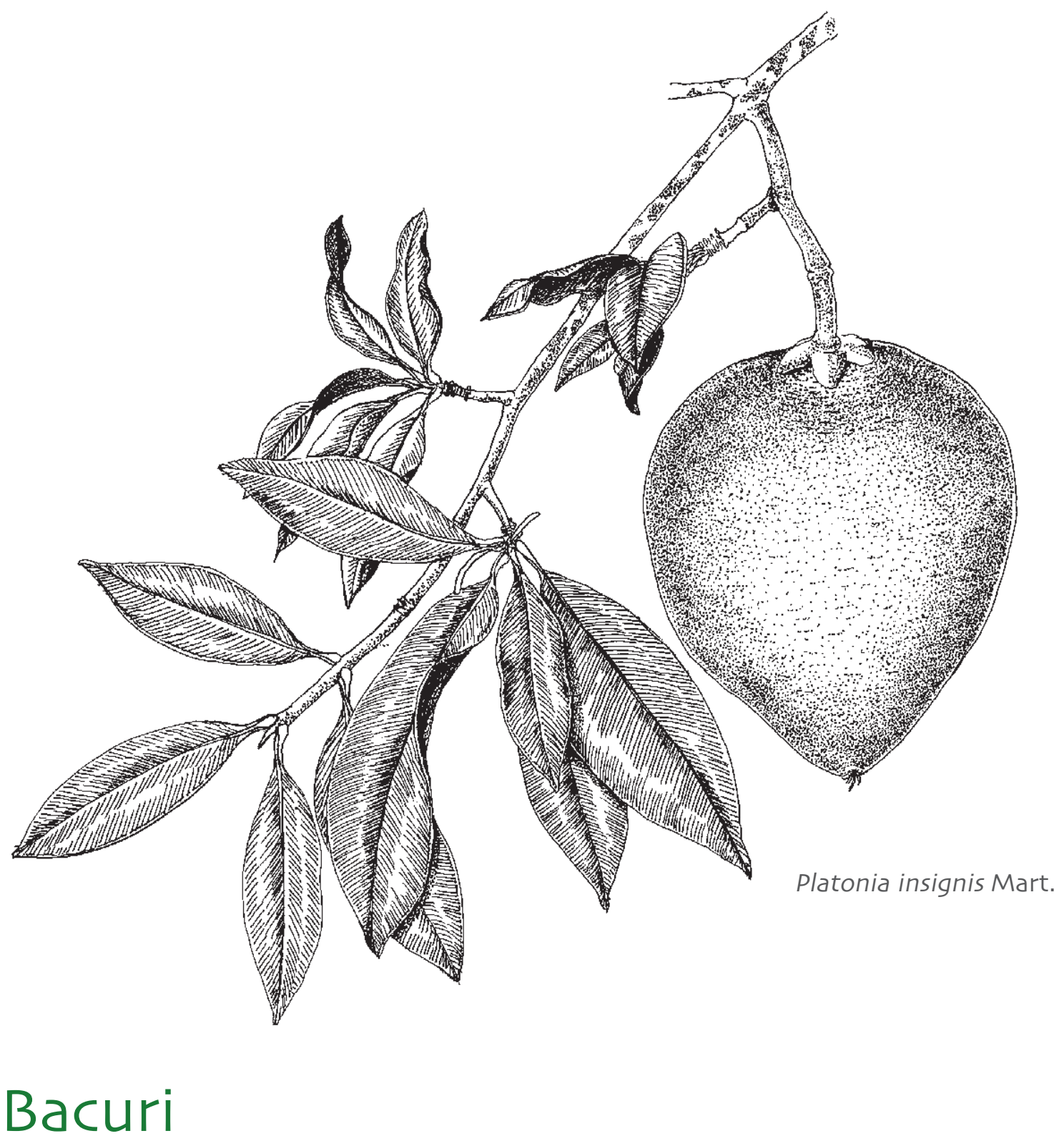

Caso brasileiro apresentado por Socorro Ferreira e Gabriel Medina 


\section{Bacuri: Ouro no mercado, delícia na boca}

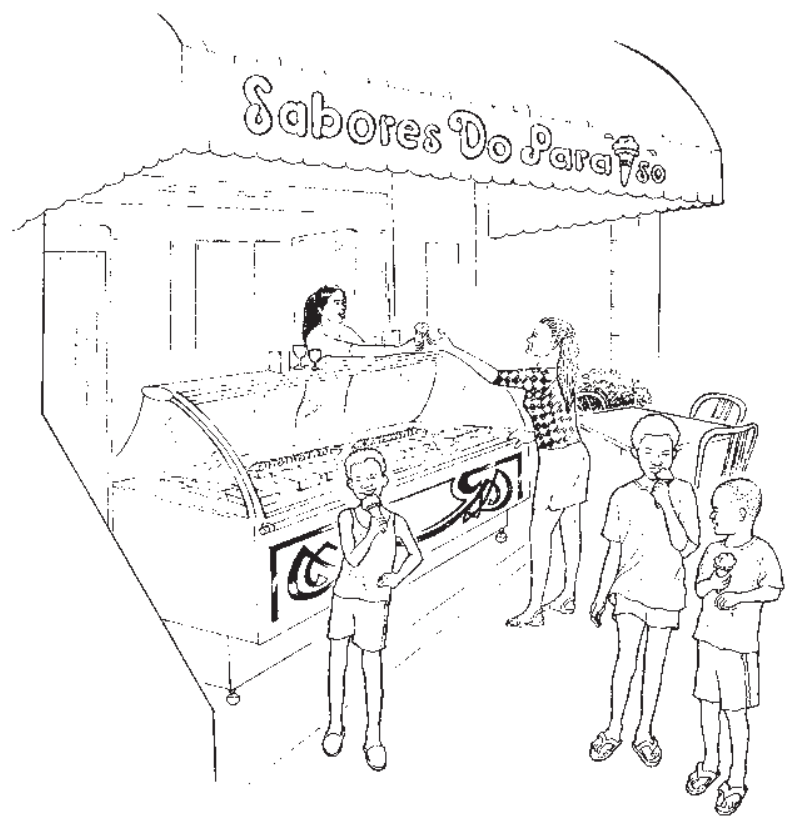

Crianças em Belém e outras cidades no norte do Brasil adoram os sorvetes com o delicioso sabor de bacuri.
Você já percebeu que cada vez que você prova uma nova fruta você tenta associar o seu sabor a algum outro que já conhece? Pois isso é quase impossível na Amazônia, porque a multitude de frutas da região têm sabores muito diversificados mas muito próprios da sua imensa floresta. Nas sorveterias e casas de sucos você pode encontrar mais de 50 sabores diferentes de frutas, o que prova a extraordinária biodiversidade* da região e a importância cultural dos seus produtos aromáticos e ricos em sabor. Das abundantes frutas, os habitantes locais sabem o que poucas outras pessoas não sabem: o bacuri (Platonia insignis), uma fruta nativa* da floresta, é uma das melhores.

O sabor da polpa* branca do bacuri é extremamente popular no norte do Brasil. No estado do Pará, algumas famílias rurais consomem mais de 600 frutas frescas durante os quatro meses da estação de frutificação do bacuri. O seu sabor diferente também está

presente em uma gama de produtos, como pudins, sorvetes, sucos, geléias, iogurtes e licores. Mas o bacuri oferece mais que somente frutas. Das suas sementes se produz um óleo, enquanto o látex grudento amarelo que brota dos ferimentos da casca do tronco é usado como cola e como emplasto para o tratamento do eczema, herpes e outras doenças da pele. Além de tudo isso, o bacuri também é cobiçado pela alta qualidade e durabilidade da sua madeira.

Até recentemente, poucas pessoas davam muita atenção ao bacuri apesar da grande gama de seus usos. Assim como a fruta do uxi (veja o caso do uxi, neste livro), sempre foi considerada uma "fruta de pobre" - barata e acessível aos habitantes da zona rural. Mas essa percepcão está mudando por conta da disparada da sua demanda nas cidades e do seu crescente valor de mercado. Como explicam os vendedores ambulantes: "O bacuri está virando ouro no mercado". Em resposta aos crescentes presos, outros dizem: "A fruta do pobre tornou-se a fruta do rico!" 
nos mercados próximos das cidades. Os intermediários vendem o seu estoque para os atacadistas, que processam a fruta para venda no varejo ou a vendem para as sorveterias. Nos centros urbanos, as mulheres separam as sementes manualmente, preparando a polpa fresca para venda ou a congelam para vendê-la mais tarde. O principal centro de comércio do bacuri está em Belém, a capital do Pará.

\section{Frutas deliciosas versus madeira durável}

Nas regiões de Salgado, Bragantina e Ilha de Marajó, uma fruta de bacuri é vendida por 4 a 6 centavos, mas em Belém, o preso de cada fruta é de 20 a 60 centavos. Esses presos podem dobrar no comeso e no final da estação, quando é mais difícil encontrar as frutas. Como cada árvore produz, em média, cerca de 400 frutas, o bacuri tem um significativo potencial para aumentar a renda das famílias em áreas próximas aos mercados. Isso é especialmente verdade se a venda das frutas for comparada à venda da árvore inteira para a indústria da madeira. O preşo de uma árvore de bacuri vendida para madeira pode ser de somente 4 reais. Os agricultores estão começando a notar o valor de suas árvores de bacuri e a reconhecer que elas produzem frutas e renda durante muitos anos, enquanto a venda da madeira traz renda uma vez só. Em áreas remotas, a opsão pelas frutas ao invés da madeira é ainda mais significativa porque o bacuri é matéria-prima para muitos produtos caseiros, e principalmente é uma importante fonte nutricional para os seus habitantes.

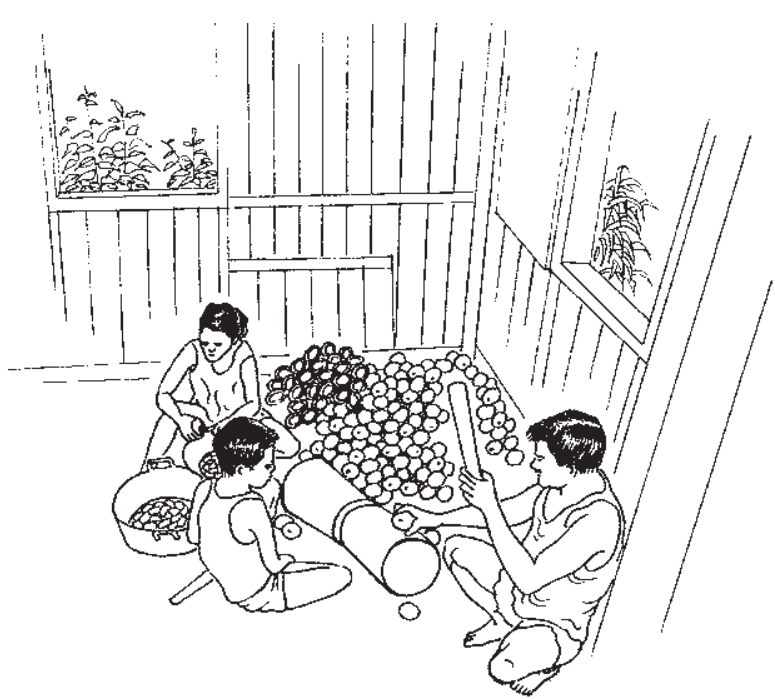

Uma família trabalha unida para partir as frutas de bacuri, batendo-as com um pesado pedaço de pau contra uma superfície dura.

\section{E daqui para adiante?}

Para atender à crescente demanda do mercado dessa fruta, os agricultores estão explorando práticas de manejo para aumentar a sua produção. No município de Bragança, por exemplo, muitas famílias estão deixando algumas áreas de roça em pousio para permitir a regeneração natural das árvores de bacuri. Depois de 12 anos, a recompensa é um pomar que pode render dividendos - deliciosas frutas e também dinheiro vivo.

A habilidade em rebrotar das árvores de bacuri nas áreas muito degradadas garante a sua sobrevivência. Entretanto, uma vez que as plântulas rebrotam das raízes da árvore mãe, grupos inteiros de plantas nessas florestas podem ser geneticamente idênticas*. Felizmente, quando se considera toda a Amazônia, pode-se observar que as frutas variam muito em quantidade polpa e sabor, indicando a existência de uma significativa variabilidade genética* e que é possível cruzar* árvores silvestres de florestas maduras com as plântulas de áreas manejadas para melhorar as características da fruta. Além de tudo, é importante lembrar também que mesmo aquelas árvores que produzem poucos frutos são úteis para muitos outros usos. 


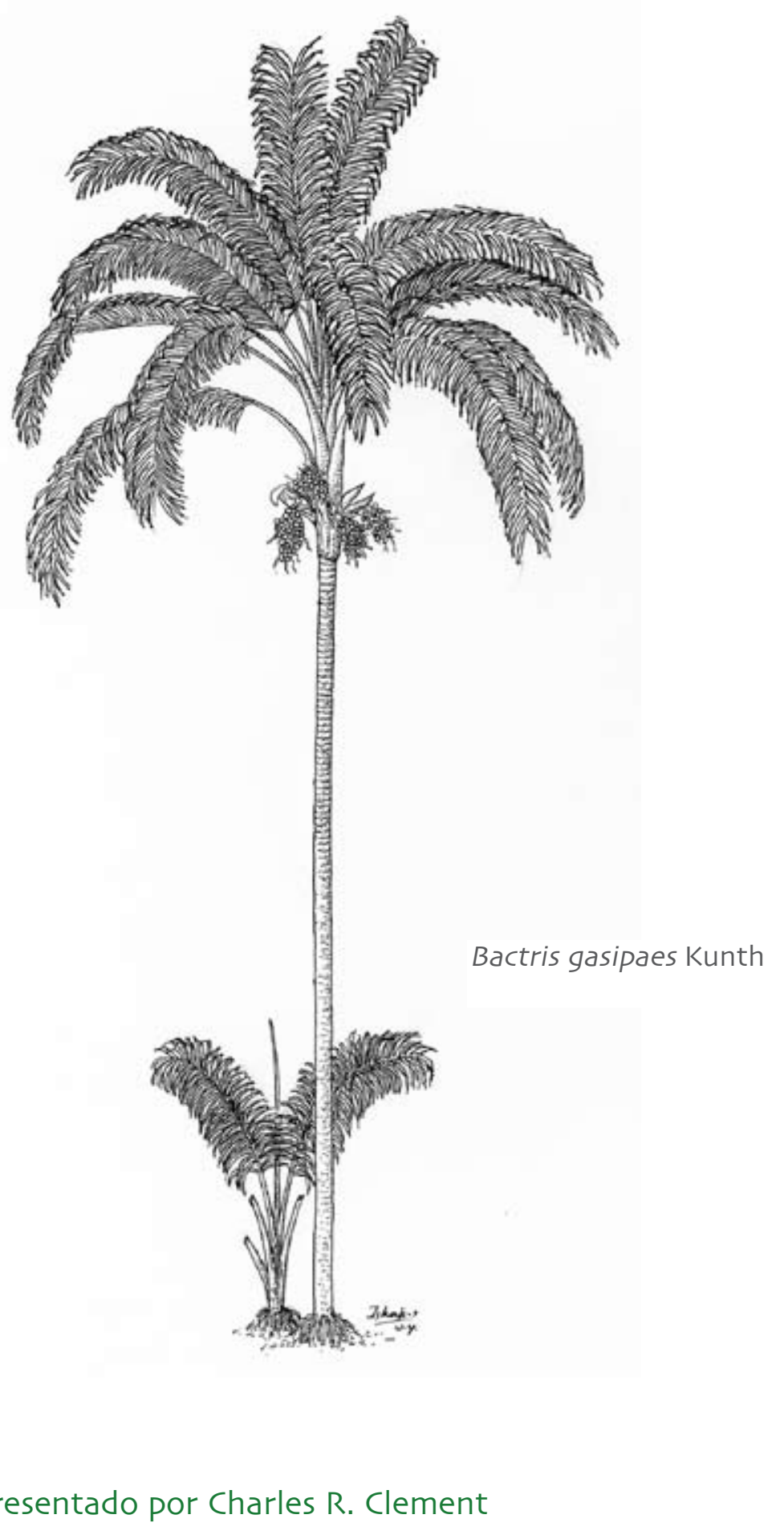




\section{Pupunha: De alimento básico a tira-gosto}

Os habitantes das zonas rurais e urbanas, da Costa Rica à Amazônia brasileira, sabem do valor da pupunha (Bactris gasipaes), pelos seus frutos ricos em amido, óleo e energia. Do tamanho de uma ameixa, os frutos apresentam todas as tonalidades de cores que vão do vermelho forte ao amarelo brilhante. Mas a colheita dos frutos pode ser bastante complicada porque o tronco dessa palmeira é coberto por espinhos que podem facilmente furar as mãos, pernas e mesmo as botas de borracha daqueles que se atrevem a subir nela.

O fruto da pupunha tem uma composição nutricional similar a do milho e os tipos vermelhos e alaranjados são ricos em vitamina A. Quando você dá uma mordida em um fruto cozido, a textura dele se parece muito com a da batata ou da mandioca; um sabor único que você logo aprende a gostar. Da mesma forma que a batata-doce, a pupunha deve ser cozida por 30 a 60 minutos em água salgada. Além de melhorar o seu sabor, o cozimento converte o

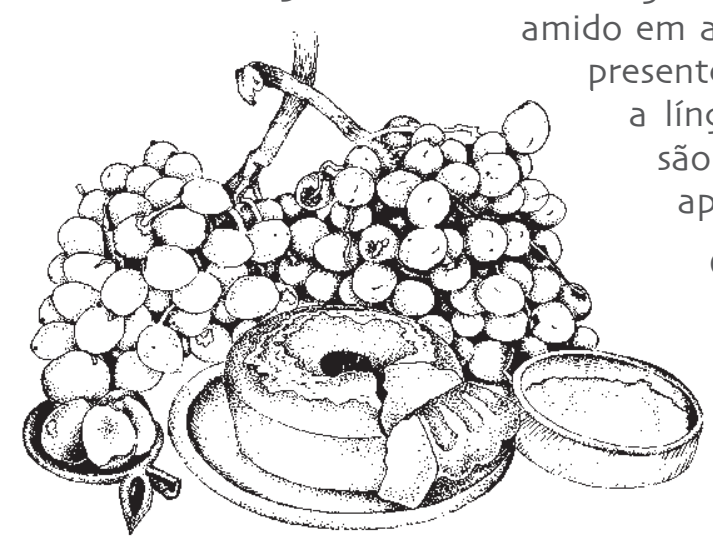

Além de ser cozida para consumo ou fermentada para a produção de cerveja, a pupunha tem sido tradicionalmente moída em farinha e usada em pães e bolos. esentes, e dissolve os cristais de oxalato de cálcio* que podem irritar

língua e a garganta. Depois do cozimento, a casca e a semente são retiradas e o fruto está pronto para ser saboreado como um aperitivo ou como acompanhamento do café da manhã.

O fruto cozido também pode ser seco e moído e transformado em uma farinha de cor alaranjada, usada para preparar pratos tradicionais ou, como no noroeste do Brasil, fermentado para produzir uma deliciosa bebida chamada caissuma. Dependendo do tempo de fermentação, o conteúdo de álcool varia de quatro por cento (menos que na cerveja) até dez por cento (como no vinho). Um pote de caissuma fermentando tem aroma de pêssegos e a bebida resultante tem um sabor mais parecido com fruta do que com amido. Foi o seu aroma que deu origem à tradução do nome pupunha como 'palmeira pêssego' para o inglês.

\section{Um afrodisíaco do campo}

A presença da pupunha em florestas abertas aparentemente maduras é um indicador da ocupação humana no passado. Há dez mil anos atrás, os primeiros habitantes da Amazônia comesaram a usar a madeira dura, durável e flexível da pupunha para fazer tigelas e arcos, arpões, lanças e outros objetos. Antes do aparecimento das ferramentas de metal, grupos indígenas* usavam facões de madeira de pupunha para cortar a vegetação mais 


\section{A venda nas ruas}

Os frutos frescos devem ser consumidos em até dois ou três dias após o processamento, uma vez que a sua durabilidade para armazenamento é muito curta sem refrigeracão. O principal mercado comercial para a pupunha exige simplesmente o seu cozimento, com os vendedores oferecendo os frutos em dúzias nas esquinas das ruas das cidades. Existe também um pequeno mercado para a madeira marrom com listras amarelas das árvores, usada para fabricação de móveis, artesanato e tacos de assoalho.

Os agricultores vendem a pupunha e outros produtos da floresta em mercados locais ou para intermediários, enquanto os grandes produtores suprem os mercados urbanos, especialmente na Colômbia e Costa Rica. Na maior parte da América Latina tropical, vendedores de rua com os seus carrinhos cozinham e oferecem a pupunha aos que passam. O processamento do fruto fresco em farinha está começando a atrair a atenção na Amazônia e já existe um pequeno mercado na Costa Rica. No norte do Brasil, uma nova moda são os 'cafés regionais', um tipo de restaurante em que se toma um café da manhã com comidas regionais, incluindo frutas da floresta, que se tornaram uma nova oportunidade de mercado para os grandes produtores e intermediários. Apesar da conhecida queda dos brasileiros pelas festas, os empresários da Amazônia ainda não despertaram para o potencial da caissuma, uma bebida que agradaria não somente aos brasileiros como também aos outros latino-americanos.

\section{Muita informasão; benefícios, nem tanto}

Assim como outras culturas secundárias, o preso dos frutos pagos na propriedade dos agricultores são baixos, oscilando entre 0,50 e 1 real (0,25 a 0,50 dólares) por cacho, chegando a 2 a 4 reais ( 1 a 2 dólares) no caso dos cachos grandes. Pequenos e grandes produtores que vivem nas proximidades de centros urbanos com forte demanda por frutos podem conseguir uma renda razoável com a venda da pupunha. Entretanto, longe dos centros urbanos, a pupunha é mais uma cultura marginal de subsistência, que lentamente yai perdendo terreno para os produtos amiláceos processados. Três décadas de pesquisa falharam em mudar essas tendências na América Latina tropical. Uma razão para o fracasso é que as instituições de pesquisa governamentais tendem a concentrar-se em produtos para os grandes mercados internacionais, ignorando as necessidades de subsistência. Como conseqüência, os pequenos lagricultores raramente se beneficiam da informação e da inovação.

Além disso, a pesquisa sobre culturas secundárias tende a ser conduzida sem um conhecimento adequado das cadeias de mercado, ou de barreiras à melhoria da producão e do comércio. Os pesquisadores precisam identificar e ter em mente as preferências dos consumidores em cada país e conseguir o tipo certo de sementes para os agricultores. A transformacão de uma cultura marginal em uma cultura comercial também requer empresários e, no caso da pupunha, eles ainda não identificaram as claras oportunidades que o potencial da cerveja, farinha e frutos de pupunha oferecem. 


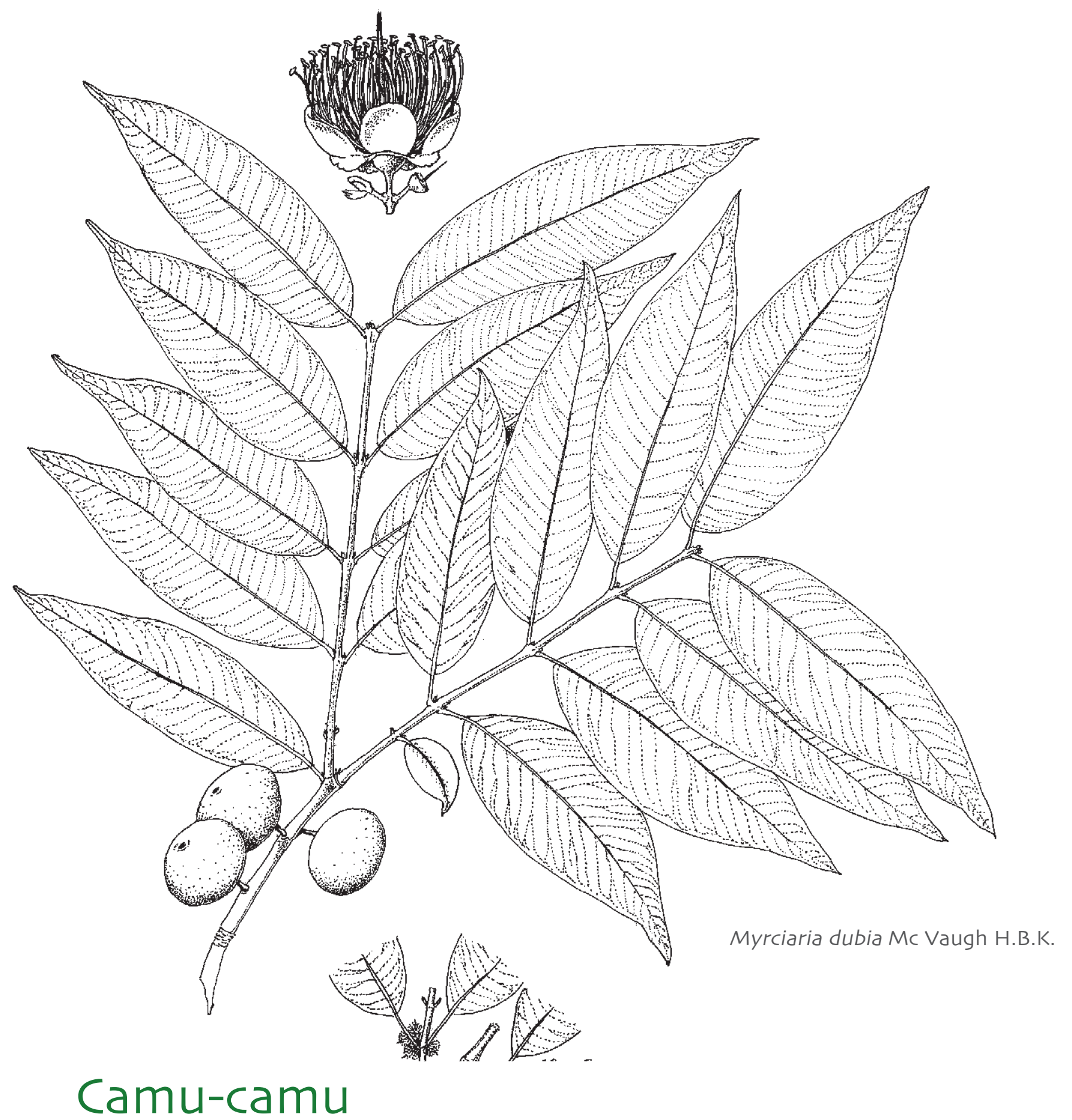

Caso peruano apresentado por Mario Pinedo Panduro 


\section{Camu-camu: A recordista mundial em vitamina $C$}

Cinqüenta anos atrás, as criancas do porto de Iquitos, no Peru, observavam curiosas os frutos de camu-camu (Myrciaria dubia) sobre as águas dos rios Itaya e Nanay, sob o olhar atento de suas mães, que desconfiavam da segurança em comer essa fruta pouco conhecida. E até não mais que dez anos atrás, as frutas do camu-camu eram consumidas somente pelos habitantes do nordeste do Peru. Hoje, porém, essas pequenas frutas de cor púrpura e forma de ameixa são apreciadas por um grande número de consumidores tanto no Peru quanto em outros países, e se converteram em uma das poucas opৎões para desenvolver a agroindústria na Amazônia peruana.

Na região nordeste do Peru, as ácidas frutas do camu-camu são comidas frescas, embora tradicionalmente elas tenham sido usadas para fazer sucos e licores. Da casca da fruta podese obter um corante de cor púrpura para tingir fibras e tecidos, enquanto a própria fruta pode servir como isca para pescar. Cascas, folhas e raízes são ainda usadas para fazer licores, xaropes medicinais e corantes.

Os habitantes da região esmagam as frutas em água com as mãos, separando a casca e as sementes. A polpa* resultante, que tem uma cor amarelo pálido e gosto de frutas cítricas, dá um refrescante suco depois de misturada com água. Na cidade de Iquitos, o principal centro de comercialização de camu-camu, a polpa da fruta é vendida fresca ou congelada, ou é transformada em sucos e sorvetes. Estudos realizados no Peru mostraram que essa nutritiva fruta tem uma concentração de vitamina C (3 017 miligramas por 100 gramas) de polpa, que pode ser considerada extremamente alta, aproximadamente 30 a 60 vezes maior que a encontrada nas laranjas. O camu-camu também apresenta

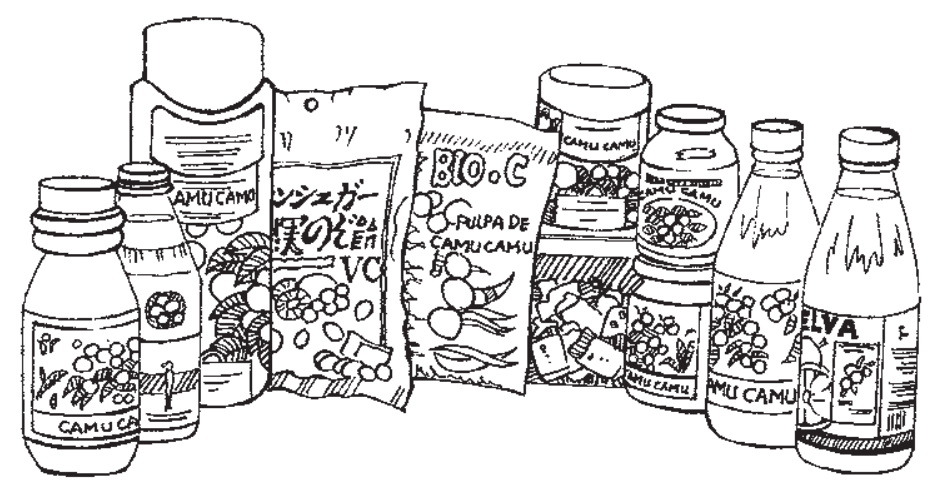

Do camu-camu se obtém uma variada gama de produtos como sucos, comprimidos, doces e xampus. benéficas fibras vegetais, que estimulam o correto funcionamento do sistema digestivo, e ainda significativos níveis de beta-caroteno, cálcio, ferro, niacina, fósforo, riboflavina, tiamina, flavonóides* e pectinas*, alguns do quais auxiliam na prevenção do câncer. Além disso, o camu-camu possui propriedades antioxidantes, antiinflamatórias*, emolientes e adstringentes*. No mercado internacional, há uma diversificada gama de produtos derivados dessa fruta, incluindo cápsulas e tabletes, e produtos alimentícios como néctares, geléias, iogurtes, sorvetes e balas. No Brasil, uma nova linha de produtos cosméticos, incluindo cremes e xampus, também está sendo produzida. 


\section{Um recurso das áreas alagadas}

O camu-camu é uma pequena árvore de quatro a oito metros de altura, que cresce nos trópicos úmidos, em altitudes de cerca de 100 metros acima do nível do mar. Ela é encontrada ao longo das barrancas dos rios e lagos, fortemente influenciadas pelo nível oscilante da água das várzeas". Essas pequenas árvores apresentam uma excepcional resistência a inundações, podendo sobreviver completamente submersas por até cinco meses.

A altitude tem importantes implicasões na determinação do retorno econômico da sua exploração. A colheita coincide com o início da estação chuvosa e com o aumento das cheias. Isso significa que nas terras baixas, onde as populações naturais ocorrem, uma grande percentagem das frutas é perdida. Tais perdas,

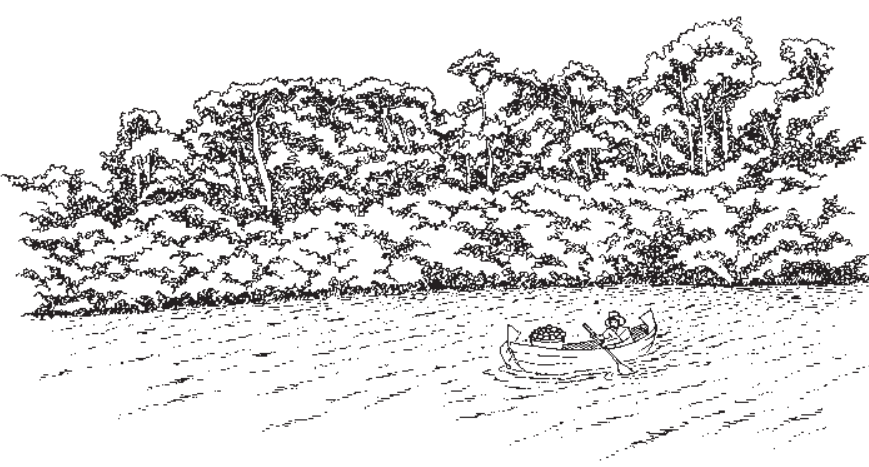

A quantidade de frutas silvestres de camu-camu que é colhida e os benefícios sócio-econômicos gerados dependem muito do nível das águas dos rios e das planícies inundáveis. entretanto, não ocorrem em regiões de maior altitude onde o camu-camu é cultivado, uma vez que as variações do nível das águas são menos drásticas.

A colheita, seja de plantasões ou de populações silvestres, não tem conseqüências detrimentais para as plantas ou para o seu ambiente já que somente as frutas são colhidas, sem causar danos para os ramos ou folhas da planta. As próprias plantas permanecem intactas e capazes de se recuperarem, garantindo os futuros suprimentos de frutas. Atualmente, mais de 90 por cento da colheita de camu-camu vêm de populaşões silvestres. Em média, cerca de cinco toneladas de frutas silvestres podem ser colhidas em um hectare. O cultivo em plantašões comesou em 1997, mas ainda não houve uma expansão continuada da área plantada para aumentar significativamente a oferta da fruta. Para todo o Peru, a safra anual de camu-camu é estimada em torno de 6760 toneladas de fruta fresca, e a extração da polpa representa uma renda anual de aproximadamente 11,8 milhões de dólares. O valor das exportações também mostra tendência de crescimento, passando de 1 377 dólares em 1997 para 73594 dólares em 2005. Neste último ano a demanda foi de 1800 toneladas de polpa* e o volume de vendas próximo a 250 toneladas, ou seja, suficiente para atender somente 14 por cento da demanda.

\section{A fruta colhida a bordo de canoas}

A renda obtida com camu-camu é importante para muitas famílias que vivem ao longo dos rios da Amazônia peruana. Uma família típica, formada pelos pais e três filhos, pode colher cerca de 200 quilos de frutas por dia, o que representa uma renda de aproximadamente 20 dólares, enquanto o salário de um dia de trabalho de um adulto é de somente 3 dólares. Os colhedores somente colhem as frutas de cor vermelho escuro, que têm as mais altas concentrasões de vitamina $C$. 
A colheita de populações silvestres normalmente é realizada dentro de canoas. Entretanto, nas plantacões das planícies ela é feita antes da cheia. A tarefa começa uns três dias depois que os frutos mudam da cor verde para rosado.

Os produtores de frutas vendem a sua colheita para intermediários que chegam às comunidades em botes equipados para processar as frutas. A polpa é separada da casca e das sementes e é imediatamente congelada. Às vezes, a polpa da fruta é desidratada, reduzindo o seu volume e peso em 50 a 90 por cento. O valor nutricional do camu-camu é alto na fruta fresca e o seu processamento imediato é fundamental para manter os seus benefícios. Quando a demanda diminui, os produtores da fruta transportam a sua mercadoria até Iquitos, onde é vendida diretamente para processadores, apesar da longa viagem de barco até a cidade poder demorar até dois dias.

\section{O futuro do camu-camu}

Apesar dos produtores não estarem organizados em associasões ou cooperativas, o que tem enfraquecido a sua capacidade de negociar melhores presos, a colheita do camu-camu ainda é uma das mais importantes opৎões econômicas para muitas famílias que vivem na Amazônia peruana. As frutas frescas e os vários produtos delas derivados têm demanda crescente tanto em nível nacional como internacional, principalmente no Japão.

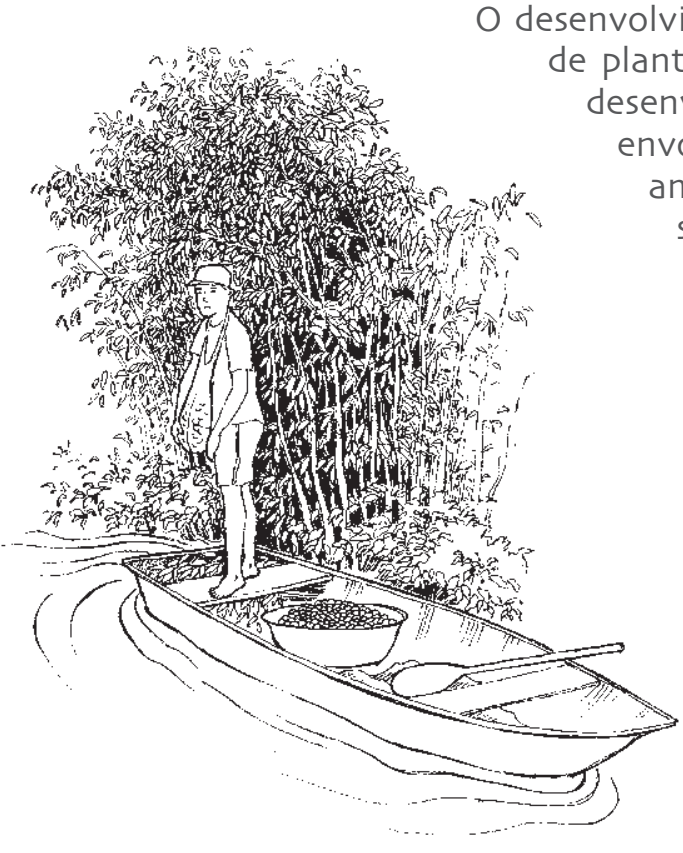

A colheita do camu-camu é feita manualmente em canoas e as frutas são colocadas em grandes bacias plásticas.
silvestres implica um alto nível de risco, particularmente por conta da impossibilidade de controlar as cheias. Ainda assim, para grande parte da Amazônia, o cenário preferencial pelos seus atributos de sustentabilidade são as planícies inundáveis.

Nos últimos anos, grande esforso tem sido feito para fortalecer o sistema produtivo e organizativo. Em 2005, por exemplo, se conseguiu a certificaşão* orgânica para produtores dos rios Ucayali e Napo, no estado de Loreto, e se iniciou um processo de normatização técnica para produtos prioritários. O Instituto de Investigasões da Amazônia Peruana (IIAP) continua desenvolvendo pesquisas sobre o camu-camu nas regiões de Loreto e Ucayali, dentro de um planejamento de longo prazo e abrangente, incluindo o manejo de populações silvestres, tecnologia de produção agrícola, manejo integrado de pragas e agregação de valor dos produtos finais. 




\section{Babasu}

Caso brasileiro apresentado por Cláudio Urbano B. Pinheiro 


\title{
Babasu: Uma palmeira colonizadora de múltiplos usos
}

\begin{abstract}
"Árvore da vida" é como poderia se chamar essa palmeira do nordeste brasileiro. Praticamente todas as partes dessa versátil planta podem ser usadas, seja como fonte de alimento, abrigo ou ingredientes para fabricar sabão e cosméticos. Deveríamos agradecer à natureza por concentrar essa grande combinação de características práticas e úteis numa mesma planta.
\end{abstract}

Por mais de um século as palmeiras babaçu (Orbignya phalerata) têm sido uma das bases da subsistência das populaşões rurais do nordeste do estado do Maranhão. O babaçu mostra todas as suas virtudes principalmente na economia das famílias rurais. Os frutos e amêndoas ainda são uma importante fonte de alimento para pessoas e para animais (como certos roedores, porcos, galinhas, etc.). Uma espécie de leite e um óleo comestível também podem ser produzidos a partir das amêndoas, enquanto da polpa dos frutos se produz a farinha de babaçu, usada como um substituto da farinha de mandioca ou como alimento para o gado. Se não bastasse tudo isso, a parte mais interna dos frutos, o endocarpo, ainda tem outro importante uso: pode ser queimado e transformado em carvão, uma fonte comum de combustível doméstico.

Além de produzir toda essa sorte de alimentos, várias partes da palmeira babaçu ainda fornecem abrigo do sol escaldante e da chuva. As casas dos agricultores e muitos dos itens nelas encontrados são feitos dessa palmeira. O tronco é um

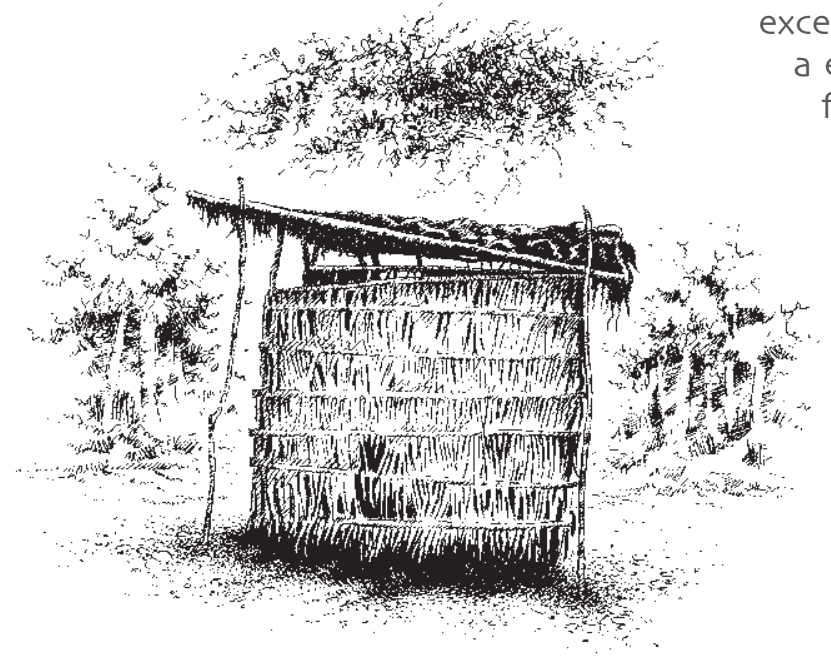

Uma planta de usos múltiplos. As frondes ou folhas da palmeira babaçu são usadas para fazer telhados tradicionais como os de quiosques. excelente material de construção, principalmente para compor

a estrutura das casas, enquanto as folhas são perfeitas para fazer os telhados. Dentro de casa, o babaçu é usado na confeção de cestos, vassouras, colchões, bancos e muitos outros utensílios domésticos.

Além dos usos que garantem a sua subsistência, o babaçu é também uma importante fonte de renda para as famílias da zona rural. Mais de um milhão de pessoas no estado do Maranhão estão envolvidas na coleta do coco de babaçu, na sua quebra para extração das amêndoas e na sua venda. Cerca de 60 por cento da amêndoa do babaçu é composta por óleos, usados industrialmente na manufatura de sabão e de produtos cosméticos. O óleo do babaçu é muito rico em uma substância chamada ácido láurico, que apresenta composição similar aos extratos de óleo de coco (Cocos nucifera) e de dendê (Elaeis guineensis). 


\section{Palmeiras babaşu: Crescendo selvagem}

O babasu é uma espécie nativa* agressiva que cresce muito bem e rapidamente em muitas condições ecológicas diferentes. Essas palmeiras cobrem extensas áreas no nordeste do Brasil, especialmente no Maranhão, onde formam vegetasões conhecidas como babasuais, semelhantes a florestas abertas, que se estendem por mais de 10 milhões de hectares. A primeira vista, um babaçual até parece uma plantação por causa do grande número de palmeiras crescendo juntas. Mas as palmeiras crescem espontaneamente tanto em terras degradadas quanto naquelas em que a floresta nativa foi derrubada, além de ser resistente ao fogo e capaz de crescer bem a pleno sol.

O seu rápido crescimento pode tornar mais difícil a vida dos agricultores que querem plantar as suas roças e dos pecuaristas que querem criar gado. Quando esses produtores começam a preparar a terra para uma nova roça, têm que trabalhar duro para abrir espaşo cortando as palmeiras. Os agricultores geralmente removem as palmeiras velhas ou improdutivas, normalmente deixando de 50 a 100 por hectare. Embora o babaçu ocupe uma grande área no nordeste do Brasil, a sua distribuição está na verdade diminuindo por causa da intensidade da mudança que vem ocorrendo no uso da terra, incluindo a sua conversão para pastagens.

\section{Um fruto duro de quebrar}

Uma floresta de babasu produz uma média de 1,7 toneladas de cocos por hectare a cada ano. Os habitantes locais juntam os frutos do chão, depois de derrubá-los com pedras ou pedaços de pau. Todos os membros da família ajudam na coleta dos frutos, mas são principalmente os homens que realizam essa atividade. Para as mulheres, tradicionalmente sobra a dura tarefa de quebrar os cocos. Essa atividade adquiriu significado especial para elas porque a venda das amêndoas representa a única fonte de renda gerada exclusivamente pelas mulheres. Conhecidas como 'quebradeiras de babasu', essas mulheres passam os dias sentadas no chão para dar conta da tediosa tarefa de remover as amêndoas dos cocos, duros como pedra, às vezes com ajuda de suas crianças. Elas colocam um coco no fio da lâmina de um machado virada para cima, e batem nele com um porrete de madeira para quebrar a casca. Normalmente são necessários dois ou três golpes para tirar as amêndoas de dentro do fruto, 
e depois de um dia inteiro de trabalho duro, 5 a $8 \mathrm{~kg}$ de amêndoas foram produzidos.

As amêndoas de babaşu são vendidas para comerciantes locais, que as revendem para processadores industriais de óleo. O processamento local, trabalho principalmente feito pelas mulheres, é restrito à extração das amêndoas. É nas fábricas que as amêndoas são prensadas ou os solventes são usados para extrair o óleo. Essa matéria-prima é então refinada e vendida como um ingrediente para a fabricação de manufaturados, como os produtos para cuidado com a pele.

\section{"Seguro verde"}

O Maranhão é um dos estados mais pobres do Brasil, e as perspectivas para desenvolvimento regional atualmente parecem ser limitadas. O babaşu é uma planta muito importante para a gente dessa parte do mundo, oferecendo uma fonte vital de renda e sustento para milhares de famílias pobres. O mercado do óleo e do amido de babaşu está consolidado e estável, enquanto o mercado do carvão está crescendo. Nessas circunstâncias, a colheita e a venda de produtos feitos com as amêndoas e frutos do babaçu continuarão a servir como um tipo de "seguro verde" contra as falhas das lavouras. Os usos de plantas para subsistência continuarão a desempenhar papel crucial para as famílias da zona rural. A importância sócio-econômica dos frutos do babaşu, juntamente com o fato de que a sua colheita não mata nem prejudica as palmeiras, ajuda a garantir o futuro desta versátil e útil espécie e, principalmente, o presente de muita gente do Nordeste.
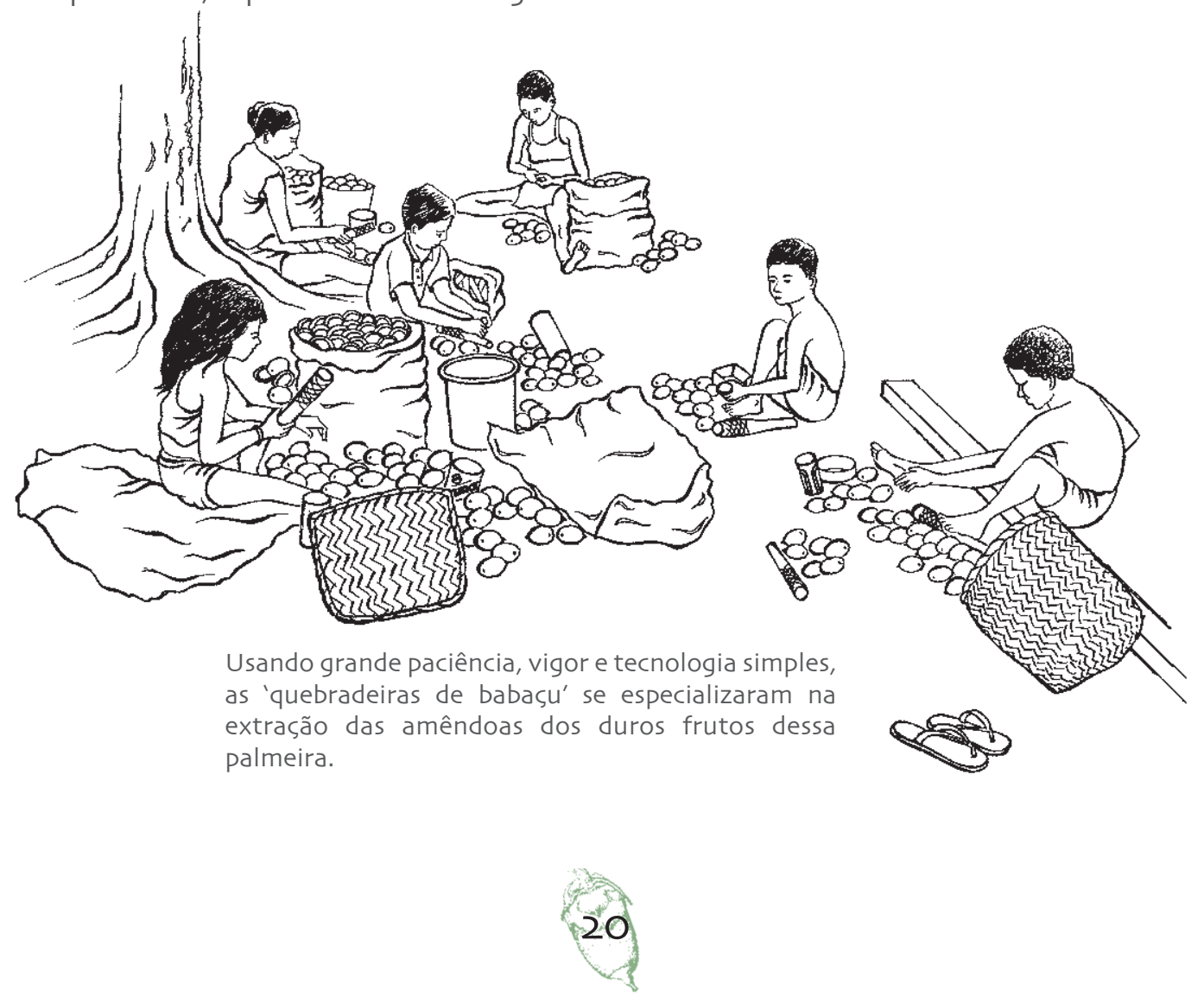


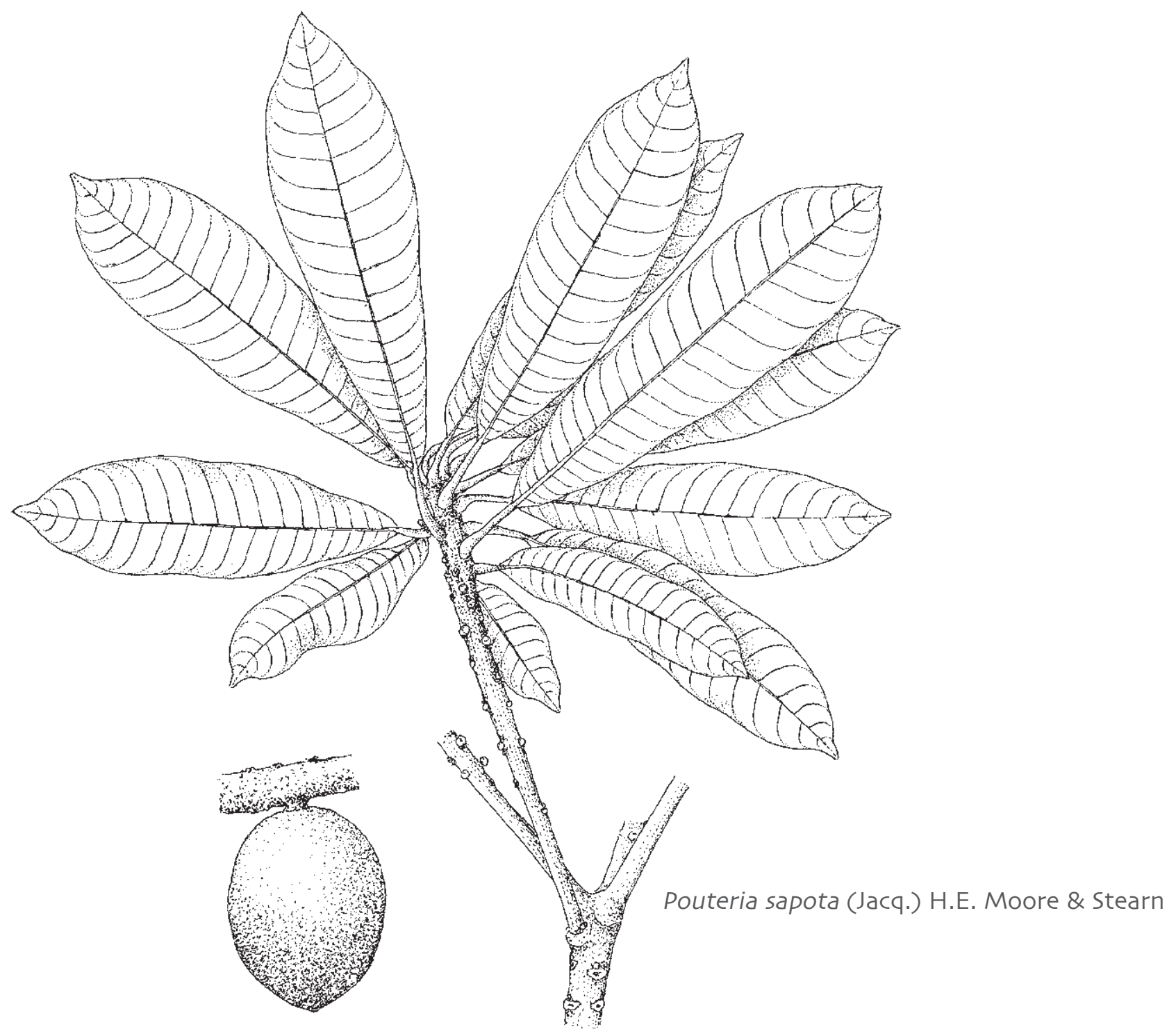

\section{Zapote mamey}

Caso mexicano apresentado por Yolanda Nava-Cruz e Martin Ricker 


\section{Zapote mamey: A doce fruta dos maias}

Muito antes dos espanhóis chegarem ao México, grupos indígenas* do sul do país, incluindo a antiga civilização Maia, tinham grande apreşo pelo 'zapote mamey' (Pouteria sapota), também chamado de 'sapota' em português. Suas frutas eram tão procuradas que os Maias a usavam para pagarem impostos. O cultivo do mamey e de outras árvores frutíferas era um componente tão forte da identidade cultural dos maias que os espanhóis decidiram eliminar os quintais das casas para exercer a sua autoridade e forçar os maias de Yucatán a deixarem a sua terra natal e se estabelecerem nos recém fundados centros missionários.

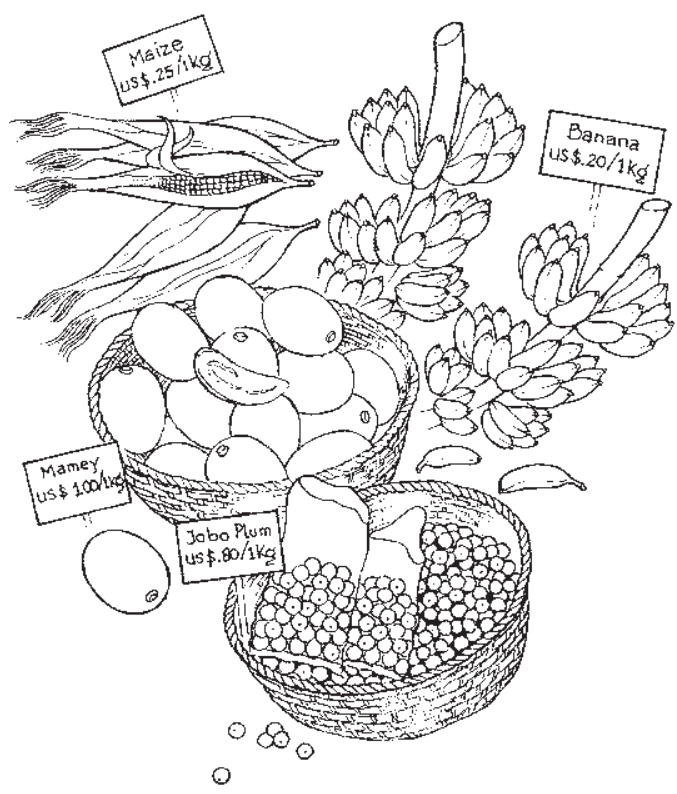

Com suas raízes na cultura indígena, os deliciosos frutos do zapote mamey tornaram-se um item de luxo nas cidades do sul e da região central do México.
Os espanhóis conseguiram expulsá-los de suas terras, mas mesmo assim os maias não perderam a sua ligação com o zapote mamey, e continuaram a aproveitar ao máximo essa versátil árvore.

Hoje, os produtos feitos como o fruto, as sementes, o látex* e a madeira dessa árvore nativa* podem ser encontrados na maior parte das casas no sul do México. O fruto tem cor salmão e sua doce polpa* é apreciada pelo seu suave e maravilhoso sabor. Os mexicanos o usam para preparar bebidas, gelatinas, sorvetes e tortas. O óleo extraído de suas sementes é usado na indústria cosmética e localmente serve como condicionador para dar brilho aos cabelos. A madeira, por sua vez, é utilizada na construção. Há ainda outros usos não tão nobres, como a mistura da seiva* do zapote mamey com o látex branco e leitoso retirado da árvore do chicle (Manilkara zapota) para adulterar a legítima goma de mascar. Por causa do seu delicioso sabor, o zapote mamey é muito mais caro do que outras frutas como a laranja e a manga, sendo por isso considerada uma fruta de luxo.

\section{Um potencial não explorado em casa}

Os botânicos não têm certeza da origem do zapote mamey, mas acreditam que ele seja nativo do sul do México e norte da América Central. A partir dessa região, foi introduzido 
em muitos países e hoje é cultivado em plantaşões tão distantes quanto os Estados Unidos, Filipinas, Indonésia, Malásia, Vietnã e Índia. Ao contrário do que ocorre nesses países, os mexicanos não distinguem diferentes variedades e não produzem as frutas em plantações. Os frutos são colhidos de árvores silvestres" ou de pequenos pomares caseiros.

No município de San Andrés Tuxtla, em Veracruz, as árvores de zapote mamey crescem nas florestas perenifólias* e mesmo em fragmentos dispersos dessa floresta. A sua distribuicão é muito esparsa, podendo-se encontrar talvez somente uma árvore por hectare, o que obriga os colhedores a percorrerem grandes distâncias para coletar a fruta. Com freqüência, duas ou três árvores podem ser encontradas entre outras espécies frutíferas nos pomares

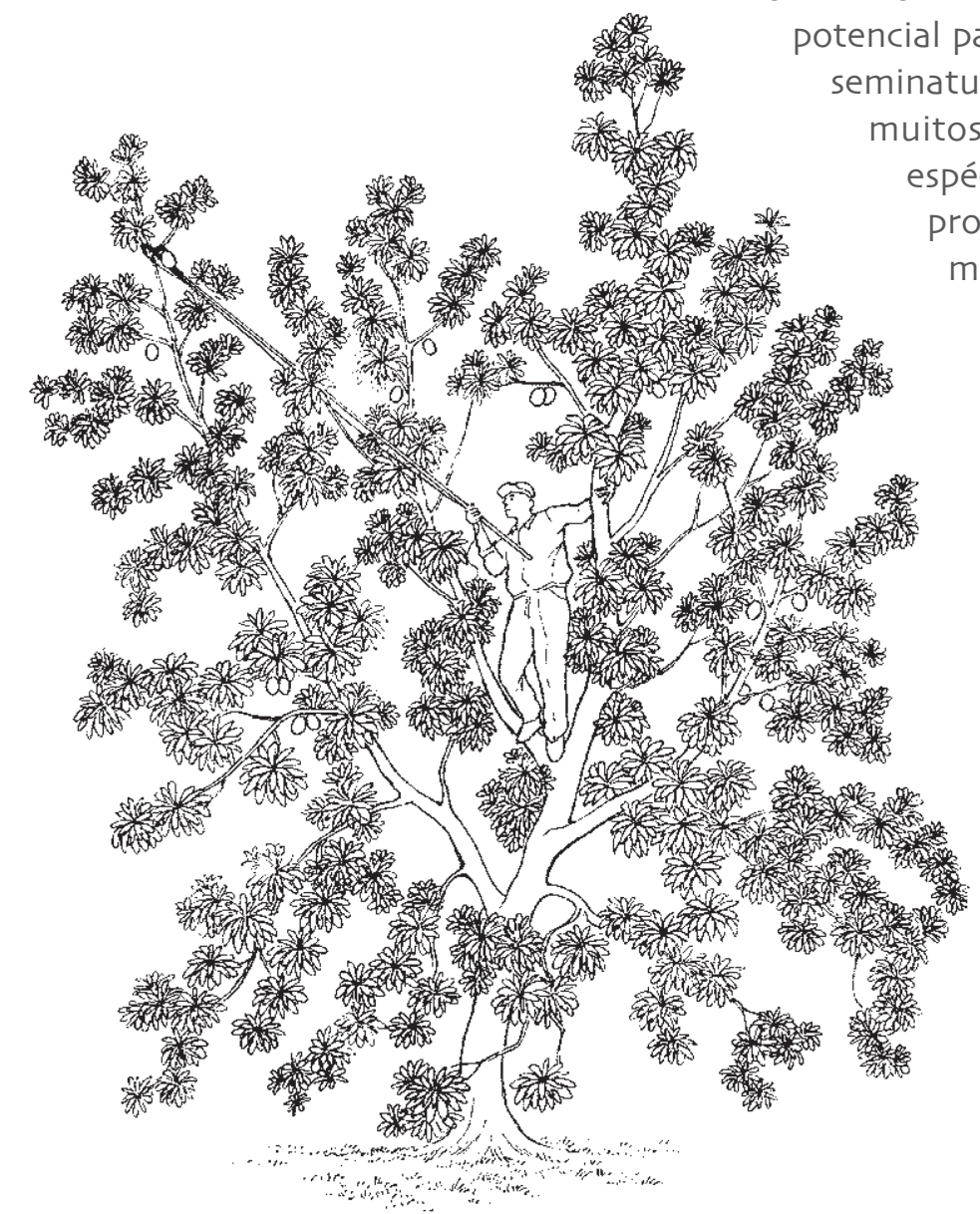

Os colhedores têm que subir nas altas árvores do zapote mamey para conseguirem colher os frutos.

\section{Pronta para a colheita}

O zapote mamey é uma árvore de grande porte que alcança os 40 metros de altura e começa a produzir frutos entre os 15 e 18 anos de idade. As frutas são colhidas normalmente entre maio e julho, quando começam a amadurecer. Durante esses meses os colhedores dedicam bastante tempo identificando árvores com um bom número de frutos aproveitáveis. Depois de negociar o preso com os donos das árvores ou da terra, retornam para colherem as frutas.

Os agricultores têm que percorrer em média uma distância de 30 quilômetros para obter uma tonelada de mamey. Em geral, visitam entre 10 e 25 árvores, que produzem entre 40 e 100 quilos cada uma. O número de frutos de uma árvore depende, entre outras coisas, da sua idade e diâmetro. Embora a renda proveniente da venda dos frutos seja mínima e esporádica 
para os donos das árvores, para os colhedores essa atividade pode representar entre 20 e 30 por cento da renda anual da família.

Para colher o zapote mamey, o colhedor sobe na árvore e, utilizando uma vara comprida com uma lâmina, corta com muito cuidado as frutas mais verdes, que vão amadurecer em poucos dias. Depois, coloca as frutas em sacolas de lona e as leva até a estrada mais próxima. Ali, ele utiliza cavalos, mulas ou burros para levar o produto até o local da comercialização. Às vezes, a fruta é transportada diretamente para os mercados locais de cidades próximas. Em outras ocasiões, é vendida para um intermediário, que a comercializa no mercado central da do México.

\section{Muito potencial, pouco apoio}

No município de San Andrés Tuxtla, os colhedores de mamey enfrentam vários problemas porque se vêem obrigados a investir muito tempo selecionando as árvores e colhendo e transportando a fruta até os pontos comerciais. Infelizmente, tanto as organizasões

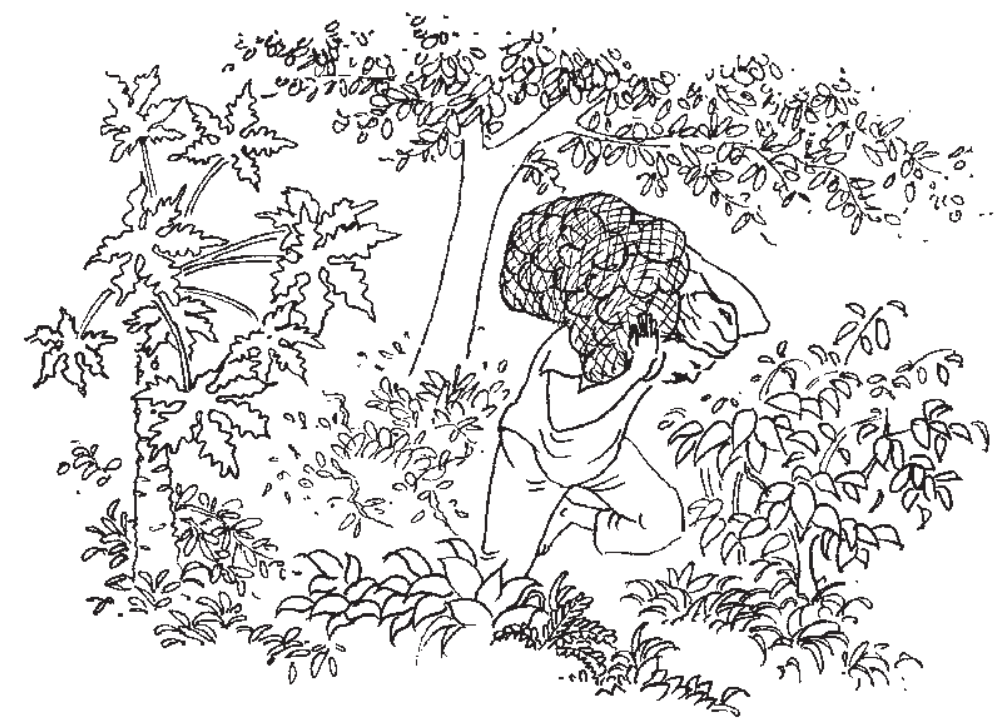

Um colhedor de zapote mamey leva uma carga de frutas até a estrada mais próxima. governamentais como as locais não têm incluído essa espécie em programas para promover cultivares de plantas frutíferas. Ao contrário, seus esforços têm sido orientados para a produção de carne, fumo e café.

Embora as perspectivas do zapote mamey como fruta de alta qualidade sejam excelentes, não há nenhuma instituição governamental ou não-governamental que incentive a procura das árvores mais promissoras para selecionálas para o cultivo em sistemas florestais seminaturais. Para realizar os benefícios potenciais do zapote mamey, está ainda por ser desenvolvido um programa integrado que permita organizar os produtores, promover o cultivo, identificar a cadeia de produção e melhorar os presos para produtores e colhedores. 


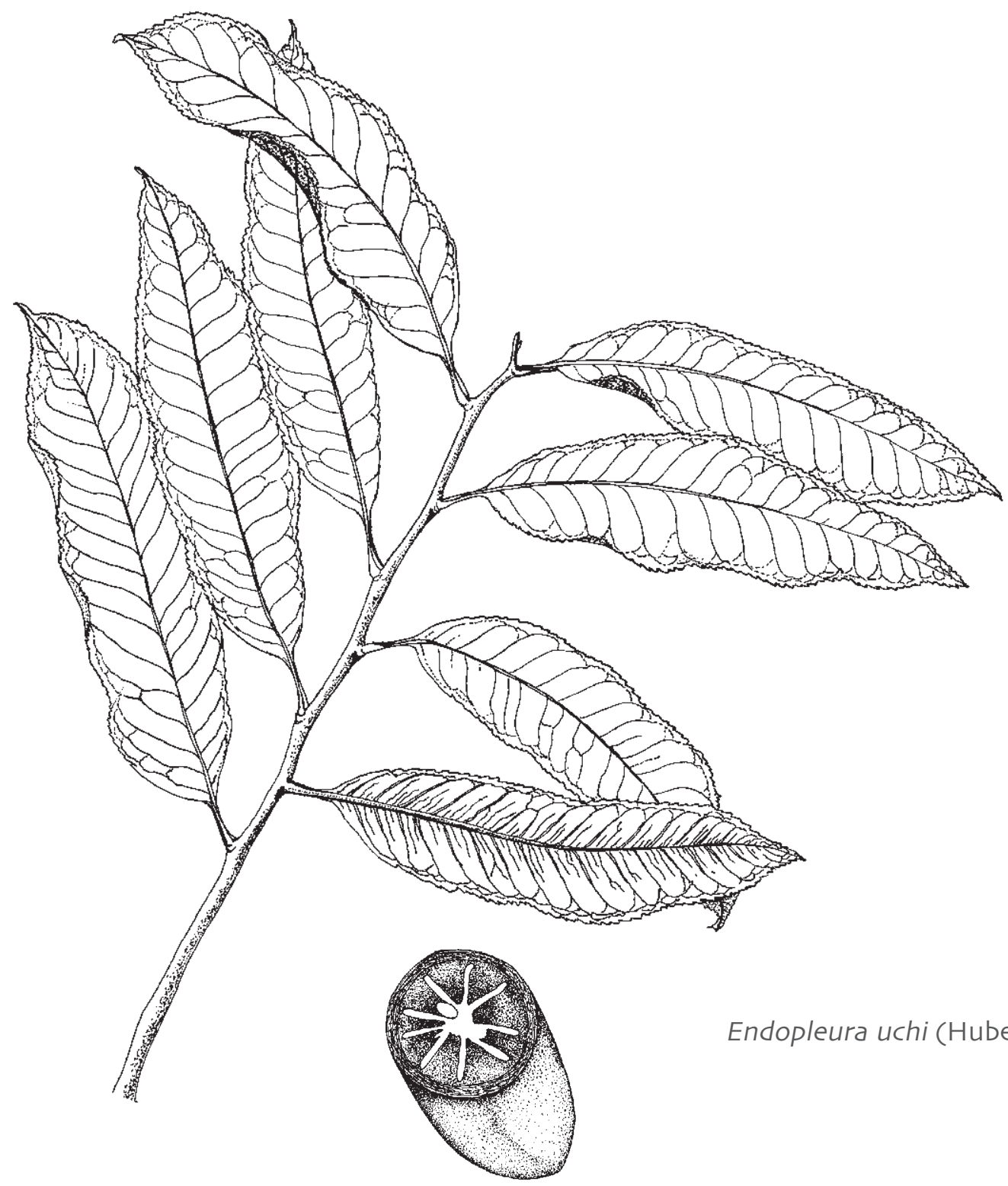

\section{Uxi}

Caso brasileiro apresentado por Patricia Shanley e Glória Gaia 


\section{Uxi: "A fruta de pobre" é um rico sabor da Amazônia}

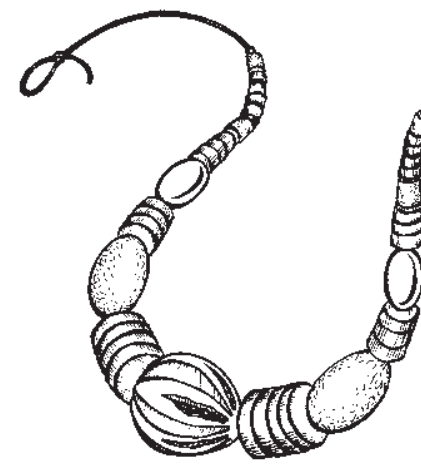

Biojóias confeccionadas com uxi são reminiscências de tempos passados, quando as cascas das sementes eram tradicionalmente usadas como amuletos.

Os habitantes da floresta que consomem uxi, uma fruta da Amazônia de cor verde-amarelada e marrom e com formato oval, dizem que nunca ficam doentes ou sentem-se fracos durante a época dessa fruta. Rico em vitaminas e minerais, o uxi era conhecido como a "fruta de pobre" porque era muito barato e acessível. Hoje, todos os amazonenses apreciam esta versátil fruta - fresca ou na forma de suco, picolés ou sorvetes. Além do alto valor nutritivo do uxi para os humanos, a fruta também alimenta uma grande variedade de animais da floresta Amazônica. A sua casca é usada para fazer um chá para tratar artrite, diabete e colesterol alto. Não bastasse tudo isso, a casca dura que envolve a semente das frutas (conhecida como endocarpo*) pode também ser usada como um poderoso amuleto na indústria de bijuterias.

Então por que o seu supermercado local não tem essa nutritiva delícia? Em primeiro lugar, porque não há quantidade suficiente dessas frutas para mandar para outros mercados. O uxi (Endopleura uchi) é geralmente colhido

de árvores silvestres, que crescem muito esparsamente, apresentando uma densidade média de apenas uma árvore a cada 1 ou 2 quilômetros. Embora os agricultores em áreas semi-urbanas próximas dos mercados estejam aumentando a produção com sucesso através do manejo das árvores, tudo o que é produzido é consumido na região. As sorveterias armazenam muito uxi na época da sua frutificação, mas geralmente o seu estoque de polpa acaba durante a entressafra. A polpa do uxi é rica em calorias e tem uma textura arenosa e oleosa. Essas são qualidades especialmente desejáveis para os habitantes da floresta que precisam de alimentos ricos em energia para sustentar o seu árduo trabalho.

\section{Os agricultores conhecem melhor que ninguém}

O uxi cresce nos estados brasileiros do Pará e do Amazonas. Ele tem sido muito pouco estudado, por isso os agricultores da floresta sabem mais que os cientistas sobre como plantar e manejar as árvores, como usar e vender a fruta. Nas florestas com pouco ou nenhum manejo, as árvores silvestres de uxi ocorrem em baixas densidades*, geralmente menos de uma por hectare e não dão frutas nos seus primeiros $15-20$ anos. Mas, no estuário amazônico próximo à cidade de Belém, os agricultores descobriram maneiras de estimularem as árvores a produzirem frutos já aos nove anos. Eles também realizam manejo para aumentar a densidade do uxi para mais de 30 árvores produtivas por hectare. Para estimular a produção e o crescimento de novas árvores, os agricultores realizam capinas, eliminando as plantas que competem com o uxi, colocam uma cobertura morta* debaixo 
das árvores, transplantam plântulas* e acabam com os ninhos de formigas usando o fogo. Em média, cada pé de uxi produz cerca de 2000 frutas durante a época de frutificação, que dura de três a quatro meses, mas algumas árvores produzem até 5000 frutas.

Se você quiser apanhar o uxi fresquinho diretamente do pé, ou colhê-lo para o mercado, você precisa passar pelas árvores com freqüência, antes das frutas serem comidas pelos seus apreciadores: porcos do mato, pacas, veados, tatus e esquilos. Um estudo em 24 árvores de uma área de 200 hectares realizado durante o período de frutificação revelou que os animais comeram 80 por cento das frutas! Algumas famílias da floresta, como a do Seu Chuva, no estado do Pará, entretanto, não se aborrecem com essa perda - aproveitam a atração dos animais pelo uxi como uma oportunidade para suplementar as suas próprias dietas: colocando armadilhas debaixo das árvores durante a época das frutas, a família do Seu Chuva e seus vizinhos saboreiam uma fonte de proteína animal diariamente, como se eles tivessem um mercado de carne fresca na porta de casa!

\section{"A fruta de pobre" vira lucro}

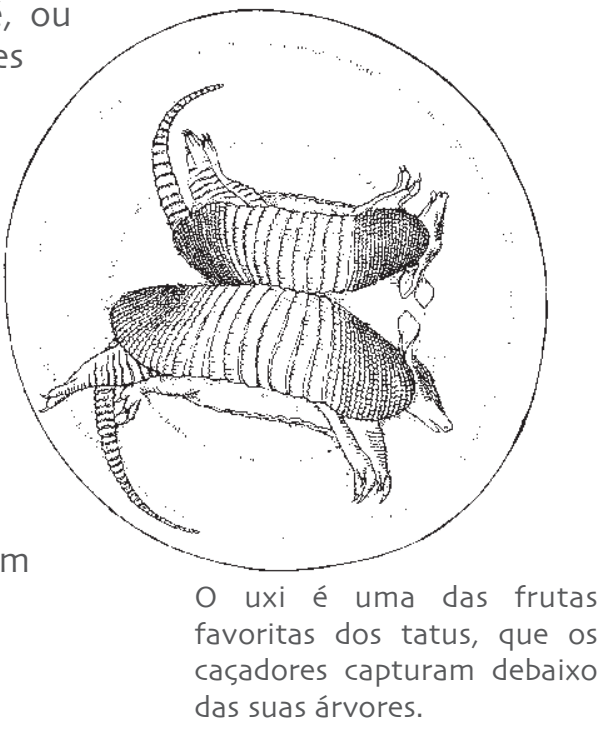

Um pequeno número de pessoas idosas que vivem em áreas remotas usa técnicas tradicionais para extrair do uxi um óleo de alta qualidade. Ele é usado para fritar peixe e fazer sabão e também como óleo para massagem ou para curar sinusite*. Além de fornecer proteínas e vitaminas extremamente carentes na dieta dos habitantes rurais da Amazônia, as frutas do uxi representam uma boa fonte de renda para um grande número de agricultores, transportadores e vendedores. Agricultores próximos a Belém que manejam os pés de uxi intensivamente juntamente com outras árvores frutíferas e palmeiras podem ganhar até 20 por cento da sua renda anual com a venda de frutas do uxi.

Enquanto os coletores ganham cerca de 1 real (0,50 dólares) por três frutos, o preso no varejo varia de 3 a 16 vezes esse valor dependendo do local da venda. No famoso mercado Ver-o-Peso em Belém, por exemplo, cada quilo de polpa congelada é vendido por cerca de 97 centavos ( 0,45 dólares). As vendas coletivas se somam: em Belém, a venda de frutas de uxi gerou um valor equivalente a mais de 384 mil reais (800 mil dólares) no ano de 2003.

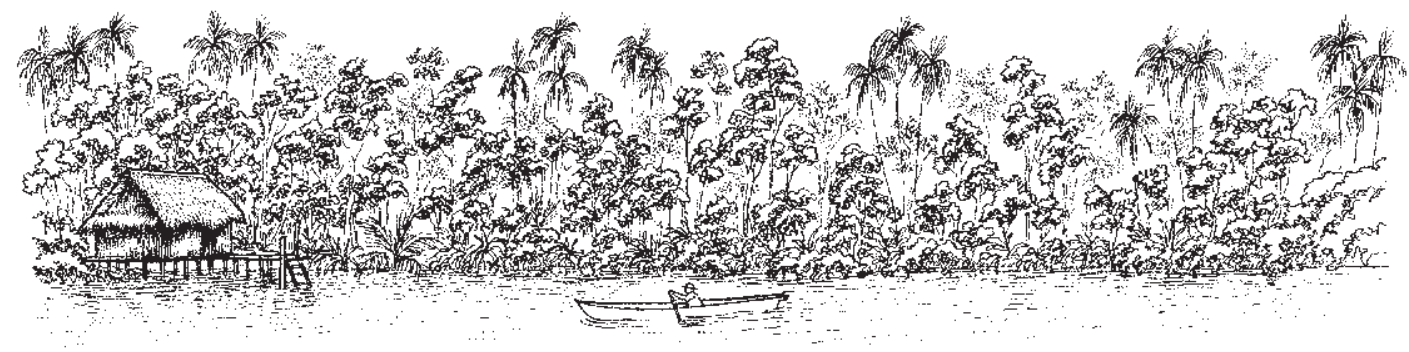




\section{Derrubando as árvores de frutas silvestres}

Além de produzir frutas nutritivas, as árvores de uxi também fornecem uma madeira de alta qualidade, e por isso é muito procurada pela indústria madeireira. Entretanto, a fina casca dessas árvores e a sua incapacidade de rebrotar após a passagem do fogo a tornam vulnerável aos efeitos de repetidos cortes e queimadas da floresta. Depois de um período de nove anos marcado por oito eventos de cortes consecutivos para produção de madeira, 19 das 24 árvores de uxi monitoradas em uma área morreram devido à combinação de corte de árvores, agricultura, ventos e fogo. Depois da derrubada, as famílias estavam consumindo em média 70 por cento menos frutas. As famílias rurais sentem a perda dessa fonte de vitaminas e proteínas tão acessível, barata e rica, e da renda que ela pode trazer.

Desatentos às conseqüências de curto e médio prazo para o seu modo de vida, e com poucas opsões de renda, as famílias geralmente vendem a madeira de suas florestas, por preços aviltantes de menos de 6 reais (3 dólares) por árvore. Os projetos que dão assistência às comunidades da floresta para que reconheçam o valor de espécies de árvores frutíferas, medicinais, oleosas e atrativas de animais de caça podem desempenhar um importante papel nessa situação, ajudando as famílias rurais a compararem os custos e benefícios do corte das árvores e a conservarem espécies de alto valor para o seu bem-estar. O uxi é uma dessas espécies; única dentro do seu gênero* e em toda a bacia Amazônica. Devido ao valor nutritivo do uxi, às propriedades curativas da sua casca e às propriedades protetoras das suas sementes, os agricultores que detêm o conhecimento sobre essa "fruta de pobre" merecem maior consideração e atenção.

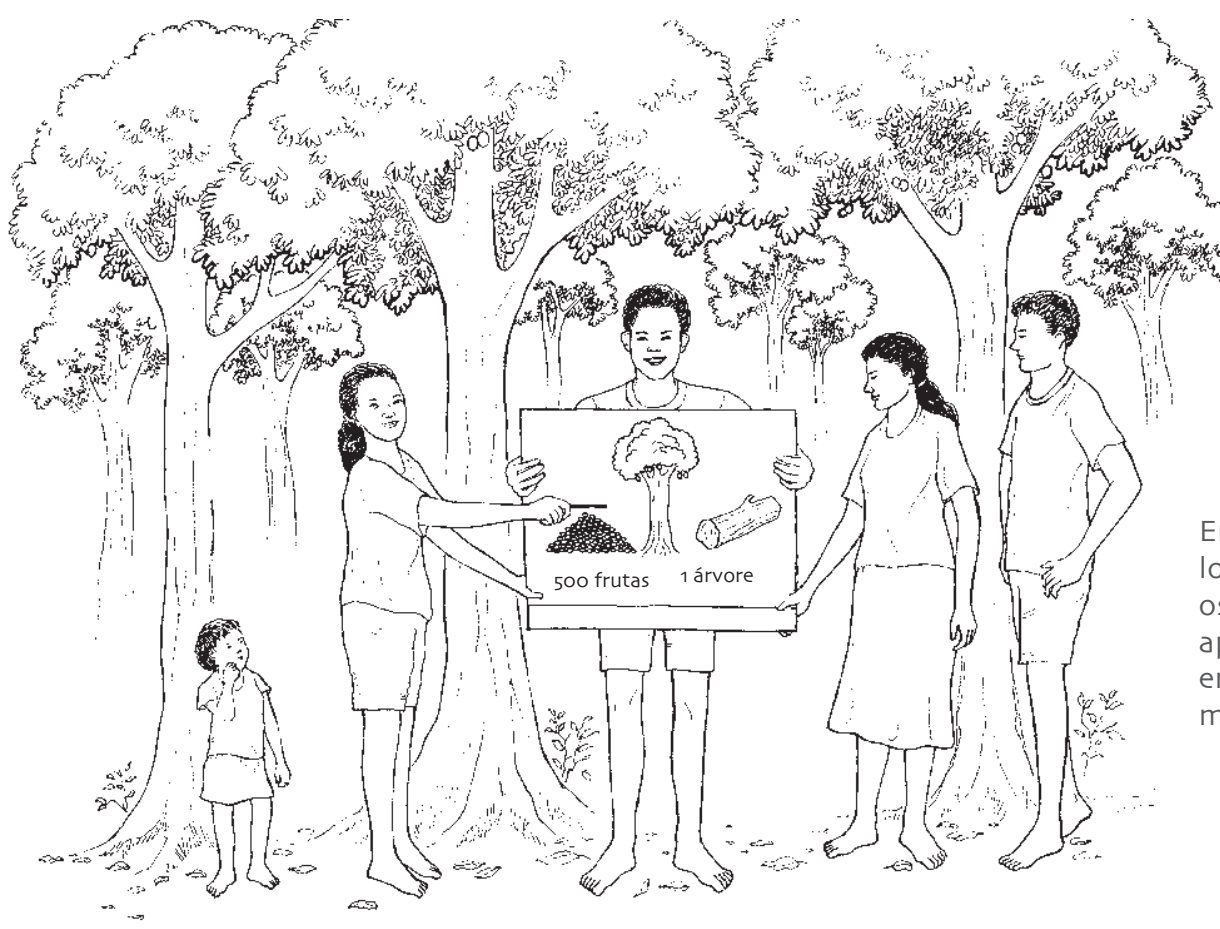

Em uma oficina sobre o valor local dos recursos florestais, os membros da comunidade aprendem o valor da fruta em comparação ao valor da madeira de uxi. 


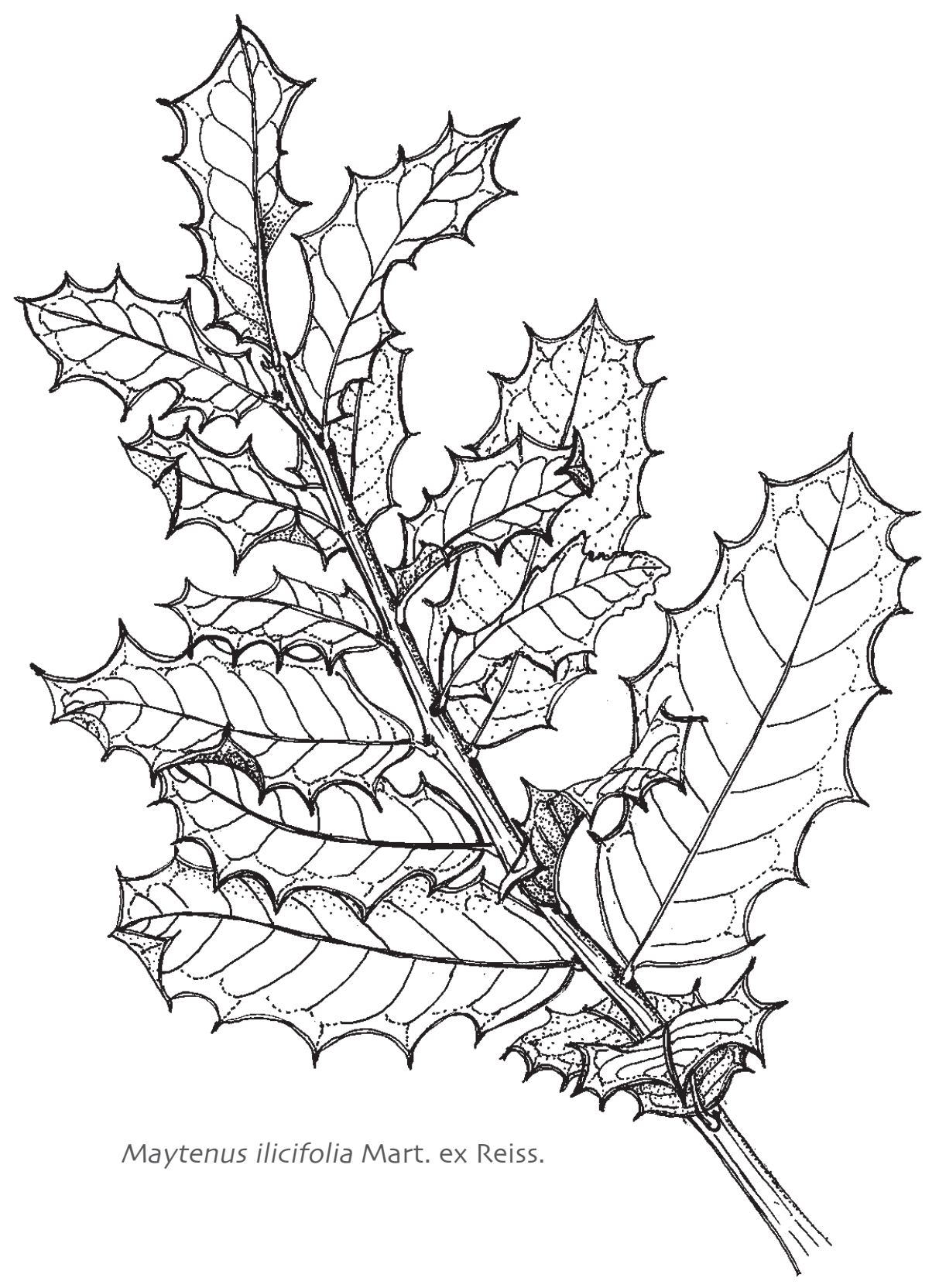

Espinheira-santa, folhas medicinais Caso brasileiro apresentado por Marianne C. Scheffer 


\section{Espinheira-santa: Folhas medicinais}

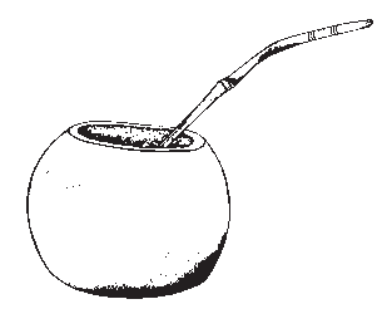

Bem antes da chegada dos europeus ao Brasil, o chimarrão, servido na cuia e com uma bomba feita de bambu, já era apreciado pelos índios guarani.

"Deus é o melhor médico, a natureza é a melhor farmácia", diz a frase na parede de uma cooperativa de agricultores no estado do Pará. Nenhum outro pensamento poderia traduzir melhor a ligaşão entre o povo e os recursos naturais no Brasil, especialmente em relação às plantas usadas tradicionalmente como remédios. A espinheira-santa (Maytenus ilicifolia) é o testemunho das propriedades curativas da natureza, com extratos de folhas sendo usados como analgésico, tônico, desinfetante, no tratamento de úlceras gástricas e na cicatrização de ferimentos.

O nome local das plantas medicinais geralmente reflete a sua importância para as pessoas que vivem longe do acesso fácil às farmácias, ou pessoas cuja renda não é suficiente para comprar remédios de laboratórios. Por exemplo, você pode adivinhar de onde vem o nome 'espinheira-santa'? 'Espinheira', é lógico, se refere aos espinhos, que crescem na borda das folhas da planta. O segundo nome, 'santa', é atribuído aos poderes curativos dessa planta e revela a devoção que as pessoas têm por ela.

Os poderes terapêuticos da espinheira-santa e de muitas outras plantas são muito bem conhecidos pelos povos do sul do Brasil. Esse conhecimento popular é um valioso presente dos índios Guarani, que habitavam a região antes da chegada dos colonizadores Europeus. Recentemente, as propriedades medicinais da espinheira-santa tornaram-se também reconhecidas no exterior, e ela tornou-se conhecida e apreciada em muitas partes do mundo.

A espinheira-santa é um arbusto atrativo que cresce naturalmente no subbosque* das florestas com araucárias* e nos campos nativos" do sul do Brasil, Paraguai, Uruguai e Argentina. Cada um dos seus frutos alaranjados contém de uma a quatro sementes, cobertas por uma mucilagem* branca. Os pássaros gostam de comer esses frutos, dispersando as suas sementes e garantindo a regeneração natural da espécie.

\section{Um poderoso chá curativo}

As folhas geralmente são misturadas com as folhas ricas em cafeína da erva-mate (Ilex paraguariensis). A mistura tem sido apreciada pelos guaranis por séculos. A infusão da ervamate, o chimarrão, em algumas partes do sul do Brasil é mais popular que o café, e muitas pessoas o tomam durante todo o dia. Assim, a quantidade total de espinheira-santa que consomem pode ser muito grande.

Sabe-se que as folhas da espinheira-santa podem prevenir e curar doenças estomacais, especialmente as úlceras gástricas. Mais recentemente, também foi demonstrada sua efetividade no tratamento de certos tipos de câncer. As vendas internacionais de espinheirasanta para países como o Japão e os Estados Unidos tiveram um enorme crescimento na 
década de 1980, logo depois que uma série de estudos documentou o seu valor medicinal.

Dez anos depois, entretanto, o mercado internacional para o produto estabilizou.

\section{O declínio dos estoques silvestres incentivam o cultivo}

Cerca de 90 por cento das folhas de espinheira-santa são extraídas diretamente das florestas. Tradicionalmente, os colhedores faziam a colheita das folhas durante o outono, quando a concentração de taninos* é mais alta e a planta não está com flores ou frutos. Seguindo o seu conhecimento local sobre o manejo da espécie no seu habitat* natural, os colhedores quebravam pequenos ramos ao invés de podarem os ramos maduros, evitando reduzir a capacidade de rebrote da planta. Além disso, a colheita das folhas feita somente uma vez a cada dois anos permitia que os ramos se recuperassem, florescessem e frutificassem. Assim, essas práticas de colheita permitiam às plantas produzirem sementes e regenerarem naturalmente as suas populasões. Nos dias de hoje, entretanto, os colhedores estão colocando uma pressão cada vez maior nos estoques naturais ao fazerem uma superexplorasão das plantas e desconsiderarem o tempo necessário para que elas se recuperem da poda.

Outro agravante da situação é o desmatamento que continua ocorrendo na região, causado por fatores como a expansão agrícola e urbana, contribuindo para o declínio da diversidade genética* e dos estoques naturais da espécie, que se tornam cada vez mais escassos enquanto a demanda pelo produto continua crescendo. Essa combinação de fatores tem levado alguns agricultores e programas de extensão governamentais a plantarem mudas de espinheira-santa nas florestas da região. Também está sendo encorajado o cultivo de espinheira-santa em campos abertos e os institutos de pesquisa, por sua vez, começaram a estudar técnicas de cultivo que possibilitem atender à demanda futura de matéria-prima.

Atualmente, as plantašões produzem somente 10 por cento da espinheira-santa colhida para comercialização. Essas plantaşões não somente reduzem a pressão sobre as populasões silvestres da espécie como também produzem folhas de melhor qualidade, principalmente com menor incidência de fungos. Os preşos das folhas refletem a diferença da qualidade entre as plantas silvestres e as cultivadas. Enquanto as folhas secas colhidas dos estoques silvestres são vendidas por 2,50 a 3,50 reais (1,25 a 1,75 dólares) o quilo, aquelas produzidas em plantacõos chegam a alcançar 8 a 12 reais (4 a 6 dólares).

No mercado, a espinheira-santa é vendida na forma de folhas picadas ou misturadas com outras ervas, chás ou tinturas. Algumas companhias farmacêuticas no Brasil também estão usando extratos dessa planta para produzir medicamentos, principalmente para tratar problemas gastrintestinais.

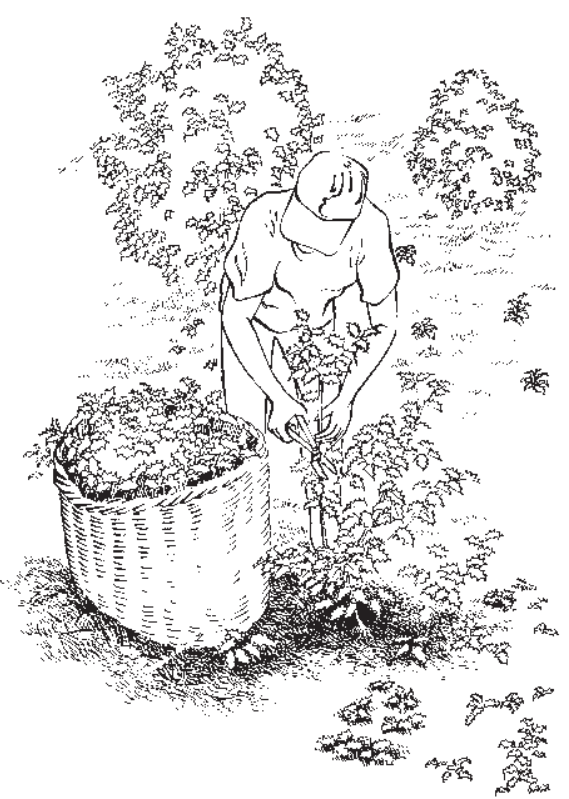

Folhas deespinheira-santageralmente coletadas pelos homens. Alguns plantas medicinais além de outras que produzem alimentos. 


\section{A demanda comercial crescente}

No passado, quando você precisava comprar espinheirasanta para prepará-la como chá ou medicamento, você simplesmente ia ao supermercado local. Essa facilidade acabou depois que as propriedades terapêuticas da planta foram confirmadas pelas pesquisas em 1988. No ano de 2000, a Agência Nacional de Vigilância Sanitária (ANVISA) reclassificou a espinheira-santa de alimento para produto medicinal. Desde então, de acordo com a lei, a espinheirasanta somente pode ser vendida como medicamento, nas farmácias. Mesmo assim, ela ainda pode ser encontrada como chá ou mistura de ervas em outros lugares, onde é vendida sem qualquer informação terapêutica. Entretanto, a maioria dos consumidores compra as folhas e medicamentos já preparados somente nas farmácias. A medida governamental não somente tornou mais difícil o acesso ao produto barato e eficaz, como também restringiu alguns usos tradicionais da espinheira-santa entre os brasileiros.

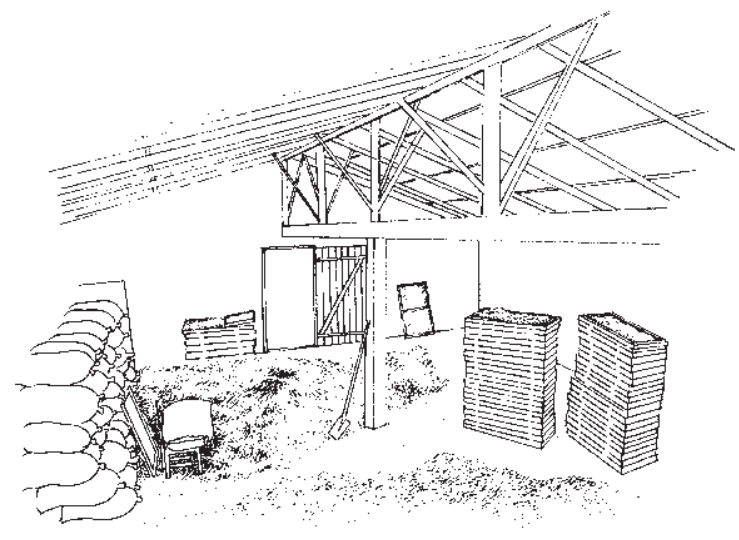

Quando as condições climáticas são boas, as folhas estão secas em dois ou três dias, completando a primeira fase do seu processamento.

Devido à longa tradição de seu uso e do recente crescimento do número de usuários e de aplicasões, o que tem estimulado a fabricasão de novos produtos, a demanda por espinheira-santa está em alta novamente. É o que confirma um recente estudo realizado no Paraná sobre as espécies medicinais registradas pela ANVISA e sobre os investimentos realizados pelos agricultores para o cultivo dessas espécies. Tendo em vista que a maior parte da oferta de folhas é ainda extraída de populações silvestres, é muito provável que estas continuem diminuindo.

Apesar de que os programas para estabelecer e expandir as plantações de espinheira-santa irão aliviar a pressão sobre as populações naturais da espécie, os seus impactos ambientais e sociais deverão ser avaliados. Por exemplo, os trabalhadores sem terra que ganham a vida coletando espinheira-santa de populações silvestres estão entre os que mais dependem dos benefícios econômicos da sua comercialização. Esses colhedores tradicionais, que não possuem terra própria nem acesso à informacão técnica sobre o cultivo, poderão ficar à margem dos benefícios das oportunidades econômicas das plantações dessa importante espécie medicinal. Assim, estratégias como o estímulo ao manejo sustentável das populaşões silvestres e a exploração de outras fontes de renda deverão fazer parte de um plano abrangente de manejo para a espinheira-santa e seus tradicionais colhedores. 


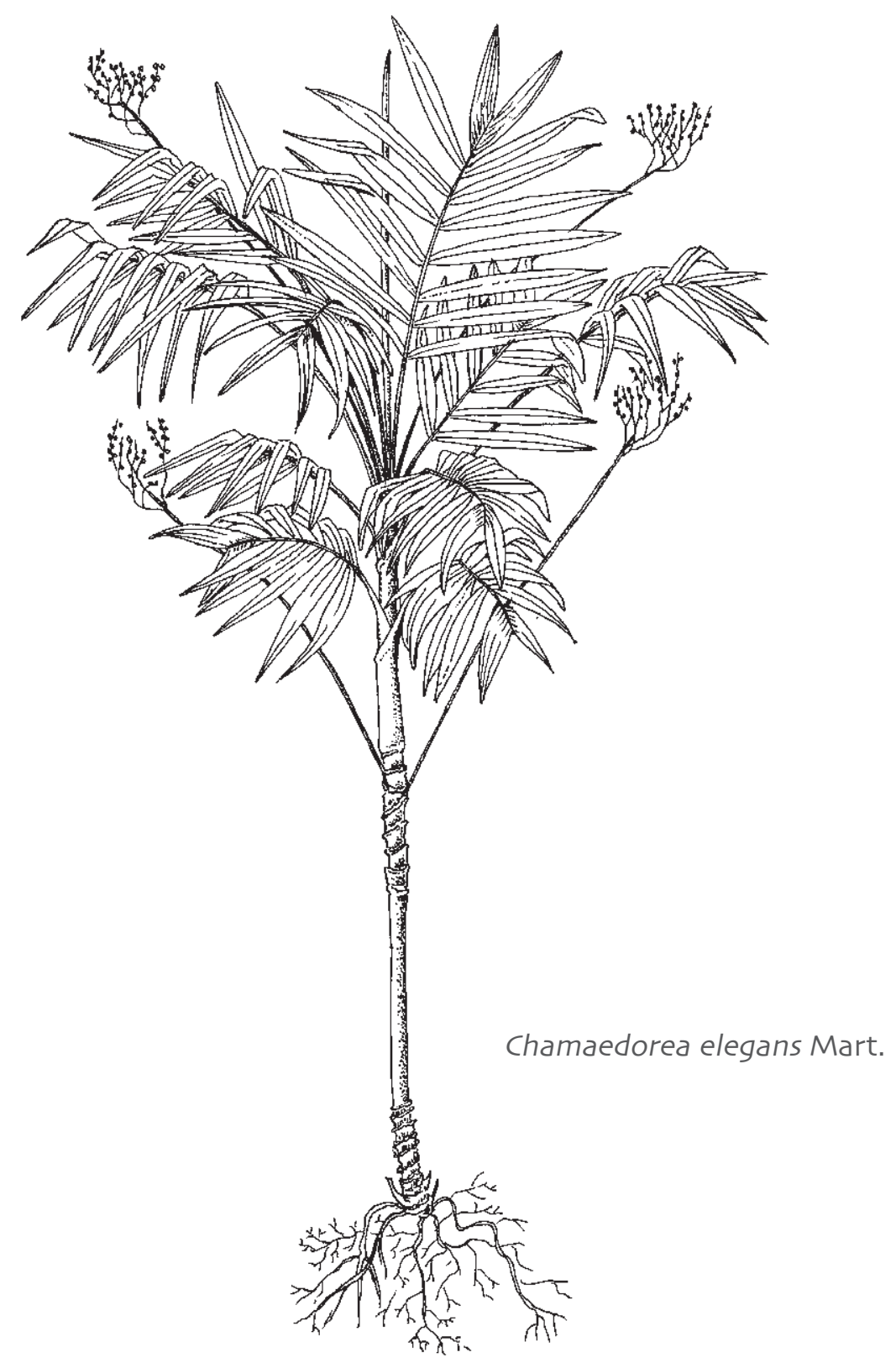

\section{Palma Camedor}

Planta ornamental, folhas decorativas

Caso mexicano apresentado por César Carrillo Trueba 


\section{Palma Camedor: Buquês de elegância}

Desde o século XIX, vasos com palmas camedor (Chamaedorea elegans) têm adornado o interior das casas e mais recentemente um novo mercado se abriu para as frondes* dessa palmeira, agora também utilizadas para compor buquês de flores. Conhecida no Brasil como palmeira-bambu e camedórea elegante e como palma xíate, no México, a palma camedor pode crescer até dois metros de altura, com troncos finos e frondes relativamente curtas de cerca de 30 centímetros de comprimento. As suas atrativas folhas depois de cortadas permanecem frescas por até um mês, característica que as tornam úteis para os floristas de todo o mundo.

A popularidade de plantas ornamentais floresceu na Europa durante a era Vitoriana, quando se tornou moda decorar as casas com plantas exóticas. Espécies da família Chamaedorea estavam entre as mais populares e eram bem conhecidas no Reino Unido pela sua capacidade de tolerar ambientes com fraca luminosidade e de manter uma folhagem verde continuamente. No final do século XIX, sementes e mudas de palma camedor podiam ser encontradas à venda em muitos viveiros de plantas em toda a Europa. Os cortes de frondes começaram a ser usados nos buquês florais nos anos 1940, quando um revendedor americano de flores de corte descobriu as folhas no México e passou a exportá-las. Desde então, comunidades indígenas* mexicanas têm colhido as folhas para exportação, juntamente com outras plantas do mesmo gênero*, principalmente C. tepejilote, C. concolor e C. oblongata.

\section{As palmeiras na floresta}

A palma camedor pode ser encontrada no sub-bosque das florestas úmidas do México e em parte da América Central. Ela cresce em solos rochosos e bem drenados com abundante quantidade de matéria-orgânica*. Em florestas virgens, podem ser encontradas até 6000 palmeiras por hectare. Como as plantas crescem naturalmente somente em florestas primárias", nunca em florestas secundárias*, a presença de palmeiras camedor é um indicador de que o ecossistema está bem conservado*. As sementes demoram cerca de nove meses para germinar" e a cada ano as plantas crescem pouco mais de 5 centímetros, produzindo cerca de quatro folhas e até seis inflorescências (grupos de flores). Até onde sabemos, as plantas que crescem em ambientes naturais não vivem mais que 20 anos, mas as plantas ornamentais podem durar mais tempo.

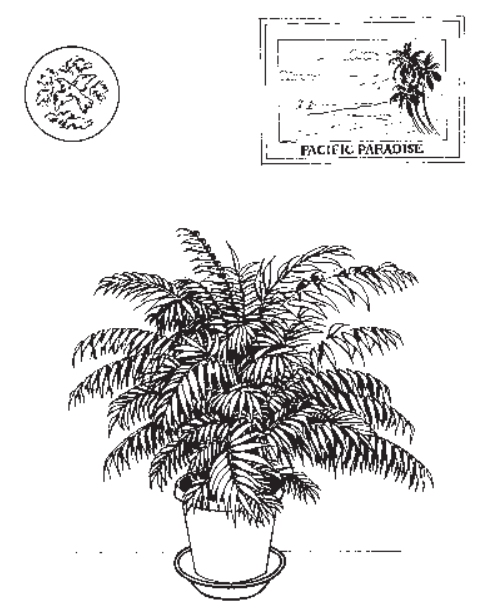

As lindas palmeiras camedor verdes são usadas para decorar o interior dos apartamentos e casas nas cidades.

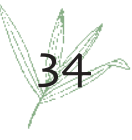




\section{Colhendo folhas e sementes}

Os colhedores geralmente trabalham em duplas ou em pequenos grupos. Eles comesam explorando as florestas conhecidas e depois avansam sobre novas áreas. Quando um colhedor chega a um novo local onde há um abundante número de palmeiras, ele pode cortar até 15 grosas (maşos contendo 144 frondes de palmas). Se as palmeiras são menos abundantes, os colhedores cortam somente de quatro a dez grosas. As palmas podem ser colhidas quando têm cerca de 4 anos de idade e começam a produzir sementes. O comprimento comercial mínimo das frondes deve ser levado em conta, mas cuidado e atenção também devem ser tomados para não cortar as folhas à altura demasiadamente baixa porque as flores podem ficar sem um suporte estrutural adequado. Devem ser deixadas duas folhas na planta e os brotos novos devem permanecer intocados.

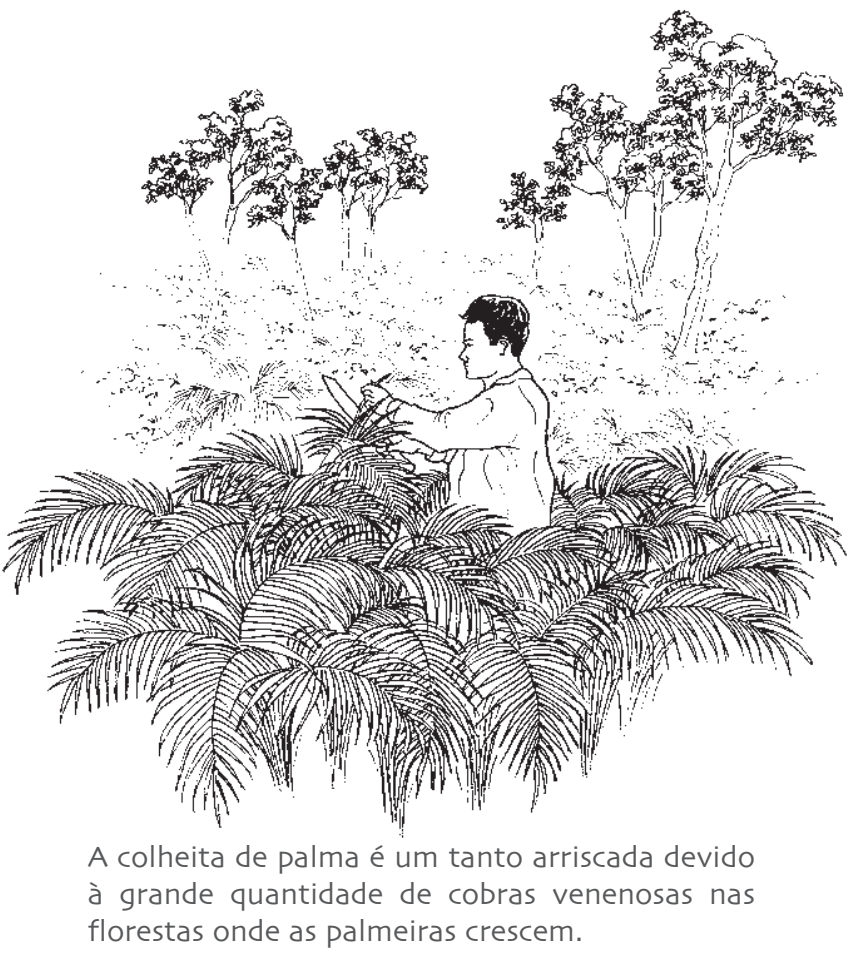

Os colhedores mexicanos recebem um dólar por cada grosa de frondes de palmas, o mesmo valor de uma única fronde vendida nos Estados Unidos. Uma comunidade pode extrair até 1000 grosas (144 mil folhas) por semana. A renda obtida pode ser relativamente pequena, mas a venda das folhas não é a sua principal atividade econômica. Os agricultores cortam as palmas como uma atividade complementar, uma fonte de renda extra, geralmente durante períodos de adversidades. O tempo que eles dedicam à colheita de palmas varia com a idade dos agricultores e com a intensidade de trabalho necessário na sua lavoura principal para subsistência, que chamam de milpa*, nos cafezais ou com a criação de gado.

Na região mexicana de Huastec, as palmeiras camedor são cultivadas nos campos, e se coleta não só as folhas, mas também as sementes. Várias décadas atrás, essas sementes eram coletadas na natureza, e apesar da nova lei florestal que proíbe essa prática, os campesinos continuam buscando as sementes nos meses de setembro a dezembro. Uma única planta produz cerca de 150 gramas de sementes, que são vendidas por quilo, cada um com cerca de 5000 sementes.

\section{A palma no exterior}

Os colhedores vendem as sementes e as folhas para intermediários locais, que por sua vez as vendem para duas grandes companhias intermediárias. Essas companhias exportam os produtos principalmente para os Estados Unidos, pequenas quantidades vão para a

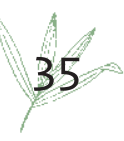


Europa e Japão. A demanda é tão grande que as companhias intermediárias começaram a estabelecer as suas próprias plantacões para aumentar a oferta.

Em 1998, o México exportou aproximadamente 225 milhões de folhas e quatro milhões de sementes para os Estados Unidos. As sementes são germinadas e cultivadas na Flórida, e as plantas resultantes são vendidas em várias partes dos Estados Unidos e Europa. Apesar das tentativas de produzir sementes nessas plantações, a palmeira cultivada não frutifica, talvez por falta de polinizadores* e ainda não se conseguiu realizar a polinização artificial* com êxito. Os povos indígenas Huastec que coletam as sementes no México têm um ditado: "Os indígenas do México dão muita alegria a Deus e por isso, Ele nos dá dois produtos - a folha e a semente. Onde estão os gringos", há somente folha."

\section{Folhas resistentes, preços baixos}

Longe de danificar a planta, a remoção de algumas frondes de fato estimula novas brotações; ao invés de produzir quatro folhas por ano, até seis novas folhas podem crescer em cada planta. Além dessa característica, a intensidade variável de colheita, juntamente com as práticas cuidadosas de manejo explicam por que, apesar do grande volume de folhas colhidas, as populaşões dessa espécie permanecem estáveis. Em áreas onde elas estão diminuindo, as principais causas são a destruição do habitat* e o declínio dos presos das culturas de grãos como o café, que motiva mais pessoas a colherem folhas da palma camedor como fonte de renda e cada vez mais com maior intensidade.

Reconhecendo essas ameaşas, várias comunidades estão empregando práticas de colheita que evitam a superexploração e protegem as palmeiras, enquanto outras estão cultivando as palmeiras camedor nas florestas locais, práticas que contribuem para a conservação desse recurso. Entretanto, os esforços de manejo das comunidades indígenas não tem tido um incentivo econômico proporcional, uma vez que os presos não têm aumentado e ainda não há esquemas de venda em sistemas de mercado justo ou certificação ecológica*. Apesar de tudo, a alta demanda internacional, o bom potencial para manejo e uma forte base de conhecimento local constituem bons fundamentos para promover programas de manejo da palma camedor.

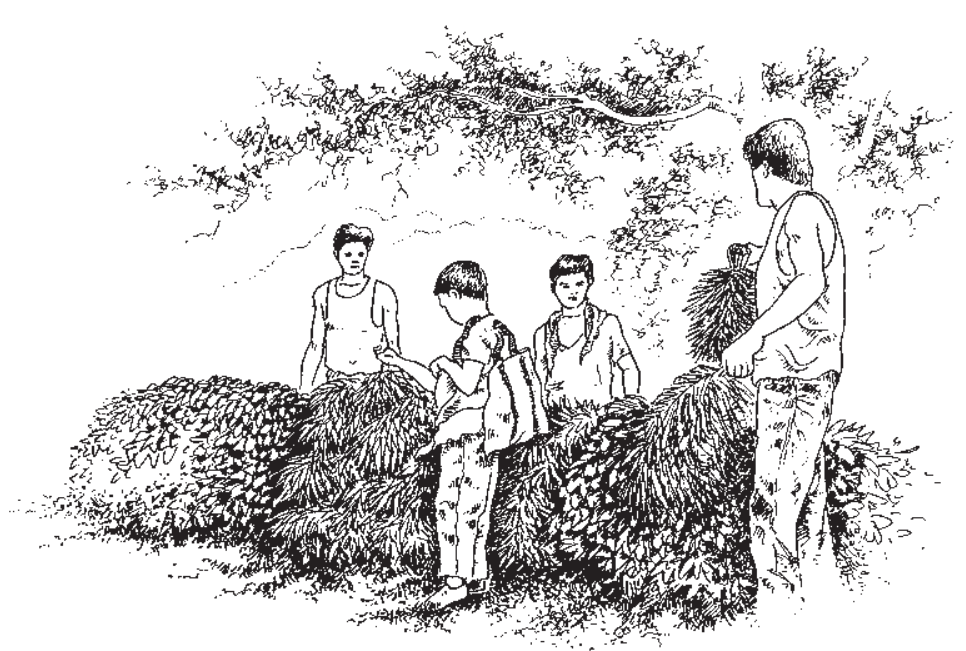

As comunidades indígenas organizam a colheita e a venda de palmeiras camedor coletivamente, o que Ihes permite conseguir melhores presos. 


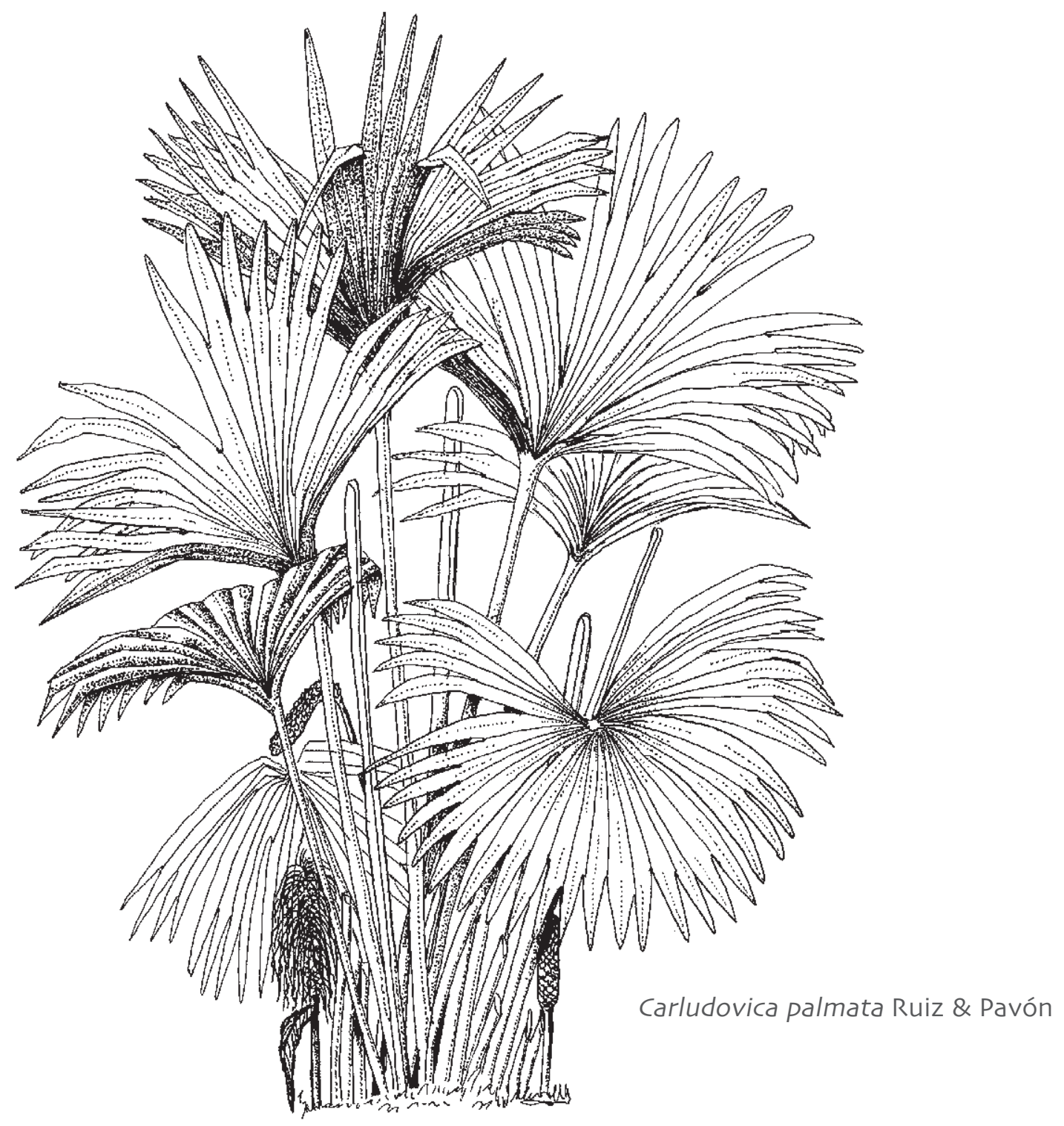

\section{Fibra Toquilha, chapéu panamá}

Caso equatoriano apresentado por Rocío Alarcón Gallegos 


\section{Equador: Berso do chapéu panamá}

Os 'chapéus panamá' são famosos em todo o mundo como um ícone da moda da América Central e do Sul, mas na verdade eles são originários do Equador, onde são fabricados com a fibra de uma planta chamada toquilla. Os povos indígenas" que viviam na costa do Pacífico do Equador têm usado essa fibra por cerca de 4000 anos e mesmo com a chegada dos conquistadores* espanhóis, os novos mesticos* continuaram a sua arte de tecer a fibra para fazer elegantes produtos. Durante os dois últimos séculos, a toquilha tem sido usada para produzir os mais finos chapéus feitos à mão do mundo - os chapéus panamá- conhecidos localmente como sombrero paja toquilla.

\section{Uma palmeira que não é palmeira}

A toquilla (Carludovica palmata) é uma planta perene* que cresce em áreas tropicais e subtropicais, do México e Panamá ao Brasil. É conhecida por diferentes nomes em diferentes países - como jipijapá na Bolívia (veja o próximo caso neste livro), onde é usada na produção de uma variedade de artigos tecidos à mão, como palma jipi no México, iraca na Colômbia, e junco em Honduras. As plantas parecem pequenas palmeiras, mas, diferentemente das palmeiras verdadeiras, os seus troncos não emergem do chão. Ao invés disso, as folhas brotam da base da planta.

A toquilha cresce em touceiras de 40 a 300 indivíduos adultos e pode ser encontrada em florestas e nas roşas. Originalmente, a matéria-prima para as fibras era coletada de plantas silvestres, mas a espécie não é mais abundante nos lugares onde foi intensivamente explorada. Atualmente, cerca de 90 por cento da fibra vêm de plantas cultivadas. Na província de Manabí, por exemplo, onde a maioria das florestas naturais já desapareceu, a toquilha é cultivada em pequenas plantasões chamadas de pajales, que começaram a ser estabelecidas há mais de um século atrás em resposta à demanda comercial daquela época.

Além do seu papel na tecelagem dos chapéus, as folhas da toquilha são freqüentemente usadas para construir telhados de casas, cozinhas e abrigo para animais, enquanto as fibras do pedúnculo das folhas são usadas para tecer cordas e barbantes. Alguns grupos indígenas na Amazônia também descobriram diferentes usos medicinais para partes da planta, como a aplicaşão de brotos e pedúnculos mascados sobre ferimentos, para evitar infeções. As plantas são ainda usadas como um presente barato e simbólico. Tradicionalmente, os filhos herdavam não somente terras de seus pais, mas também algumas touceiras de toquilla ou pajales, como um símbolo de garantia financeira para um futuro seguro.

\section{A história e comércio de chapéu}

A técnica da tecelagem do chapéu panamá é muito antiga, assim como o costume dos homens usarem esses elegantes chapéus brancos para se protegerem do sol. O comércio de 


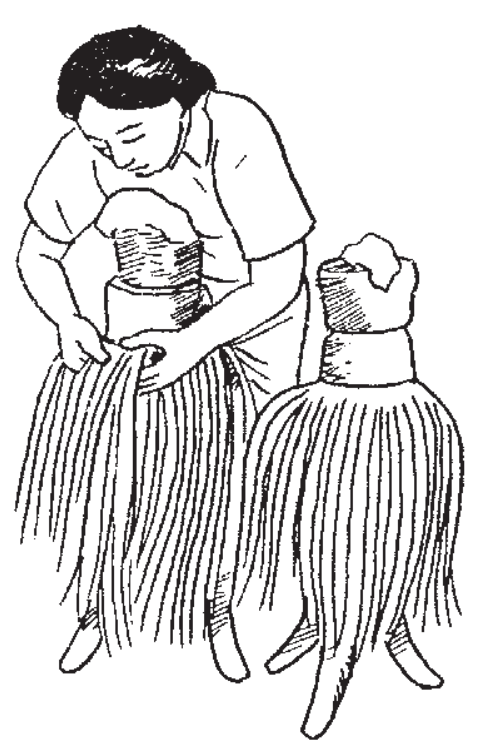

Mulheres artesãs permanecem de pé enquanto tecem, curvando os quadris e se apoiando sobre os blocos de redondos de madeira. chapéus, entretanto, comeşou somente durante o período colonial. Entre os séculos XVI e XVIII, os chapéus eram itens muito valiosos, somente usados pela elite. Por volta de 1810, o chapéu panamá tornou-se o mais importante produto exportado do Equador para a Espanha. Sabe-se que o rei Carlos IV da Espanha deu um desses chapéus como presente a Napoleão Bonaparte.

Durante os dois séculos seguintes, a demanda e a produção do chapéu panamá continuaram a crescer. Na América do Sul e Central, os chapéus eram muito populares. Eles se tornaram parte do uniforme dos trabalhadores do Canal do Panamá, dos militares da região equatoriana de Cuenca e dos guerrilheiros para a libertação de Cuba. Mas como a maior parte dos chapéus foi exportada para a Europa através do Panamá é daí que vem a sua identidade equivocada.

Na época em que a produção atingiu o seu auge, no século XIX, cerca de 88 ooo habitantes de Cuenca estavam envolvidos na confeç̧ão dos chapéus. A quantidade exportada atingiu meio milhão de chapéus por ano, fazendo deles o segundo item mais importante das exportaš̃es, depois do cacau. Mas a demanda comesou a cair pelo início do século XX, principalmente como resultado da competição dos substitutos asiáticos mais baratos. A produção estabilizou nas décadas recentes, devido ao crescimento do mercado de fibras naturais e de produtos artesanais tradicionais ou indígenas, apreciados por consumidores do Brasil, Europa e Estados Unidos.

\section{As mulheres tecem ao raiar do dia e ao anoitecer}

Nas comunidades de toda a província de Manabí, homens e mulheres compartilham o trabalho de produzir chapéus. Os homens vão em busca de plantas adultas adequadas, aquelas com os brotos das folhas centrais ainda por abrir e os colhem usando um facão. Em casa, as mulheres extraem as fibras, uma atividade árdua e morosa e que requer experiência. Elas removem a folha externa que protege o broto e separam os folíolos individuais da palma para obter as fibras. Essas fibras são então cozidas e branqueadas com ácido sulfúrico antes de serem penduradas para secarem.

Os chapéus panamá são feitos com fibras muito finamente tecidas, um trabalho que reflete séculos de conhecimento local passado de geração a geração. A tecelagem só é feita pela manhã bem cedo ou à noite, quando a umidade é alta e as fibras estão mais flexíveis. As mulheres tecem por aproximadamente seis horas por dia, permanecendo de pé enquanto trabalham para que consigam criar os mais finos tecidos. São

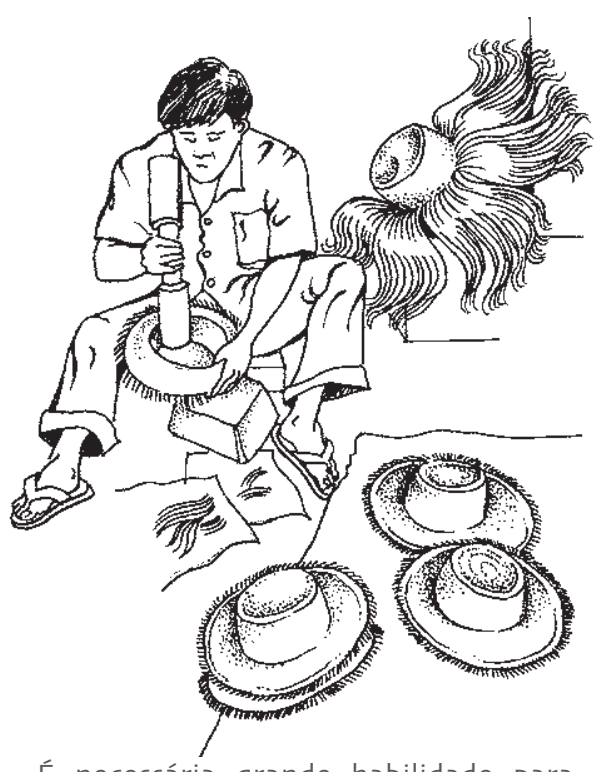

É necessária grande habilidade para bater os chapéus para amaciar sem danificar as suas fibras. 


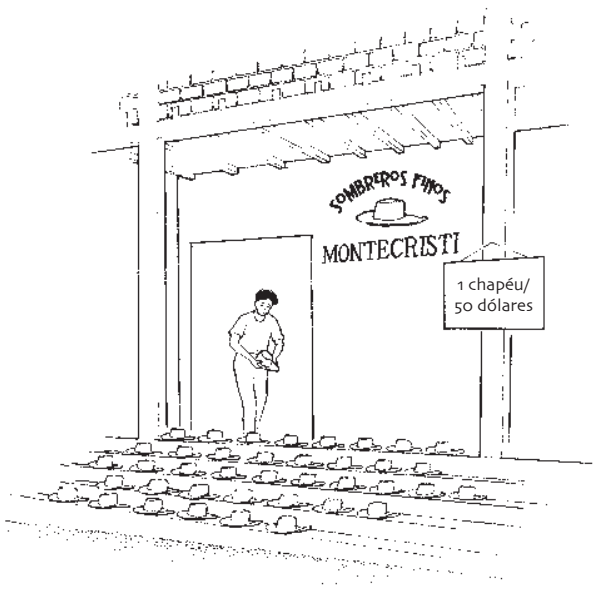

Os chapéus panamá são vendidos em pequenas lojas da província andina de Manabí, o coração da produção de chapéus, por cerca de 50 dólares cada.

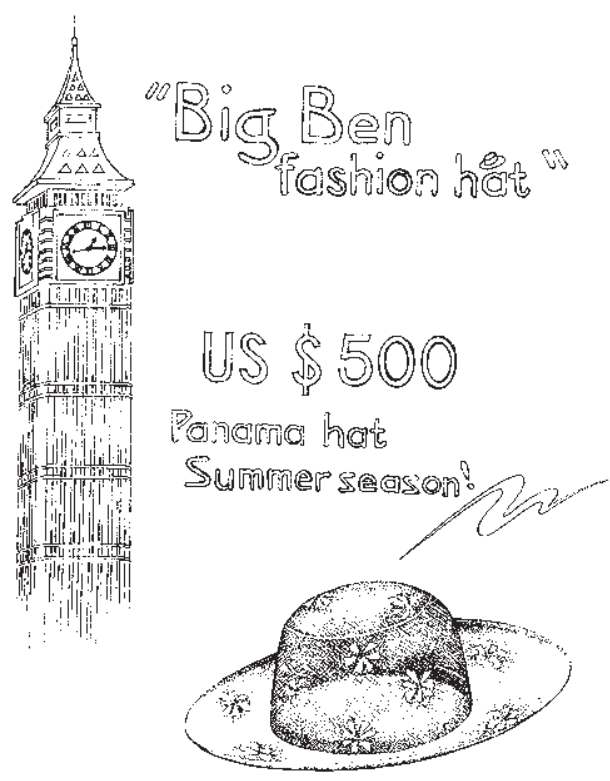

Exportados para países como a Inglaterra, os chapéus do Panamá viraram artigos da moda muito valiosos. necessários cerca de três meses ou 540 horas para confeccionar um único chapéu da melhor qualidade. Diferentes tipos de chapéus são produzidos, e os melhores são tão flexíveis que podem ser dobrados sem que as fibras se quebrem.

Os chapéus tecidos são acabados por especialistas, que transam as pontas soltas das palhas para formar uma borda resistente e aparam os excessos. Os chapéus são então macerados com um macete especial de madeira dura para amaciar a palha e finalmente são passados a ferro para criar a aparência lisa e lustrosa característica do produto.

Alguns artesãos compram fibras ao invés de cortar e processar eles mesmos a toquilha. Feixes de 96 folhas são vendidos por aproximadamente 1,20 dólares. Aos trabalhadores são pagos 2 dólares para separar as tiras e secar os feixes, e as folhas já preparadas passam a valer cerca de 3,85 dólares. Cada chapéu semi-acabado consome aproximadamente 24 folhas e é vendido localmente para os atravessadores por cerca de 15 dólares. Os atravessadores, então, dão o formato ao chapéu ou contratam especialistas para realizar o trabalho. Os chapéus acabados são vendidos nos mercados locais por presos tão baixos quanto 50 dólares, mas na Europa ou nos Estados Unidos os chapéus de melhor qualidade podem custar 500 dólares.

\section{A queda do chapéu panamá?}

A tecelagem de chapéus tem sido uma atividade tradicional secular, e na província de Manabí, no Equador, representa a única fonte de renda para muitas mulheres. Apesar da sua reputação mundial e dos altos presos que os chapéus atingem, o que os agricultores e artesãos recebem em troca é muito pouco. Essa situação está levando alguns colhedores de toquilla e produtores de chapéus a buscarem uma alternativa para ganhar a vida.

Ao longo do tempo, a qualidade dos chapéus tem declinado. Enquanto o chapéu de um coronel podia ser dobrado até ficar menor que uma bola de golfe, os chapéus de hoje são mais grosseiros e menos flexíveis. Poucas mulheres ainda têm a paciência e vigor para despertarem antes do amanhecer e tecer novamente depois do pôr do sol. Além disso, algumas jovens começaram a migrar da região em busca de trabalhos menos duros e mais rentáveis fora das suas comunidades. Se os presos permanecerem baixos, os agricultores podem passar a cultivar outros produtos ao invés de planta de toquilha. A continuar a situação que vivem esses agricultores, não há como salvaguardar o futuro dos famosos chapéus do Equador. 


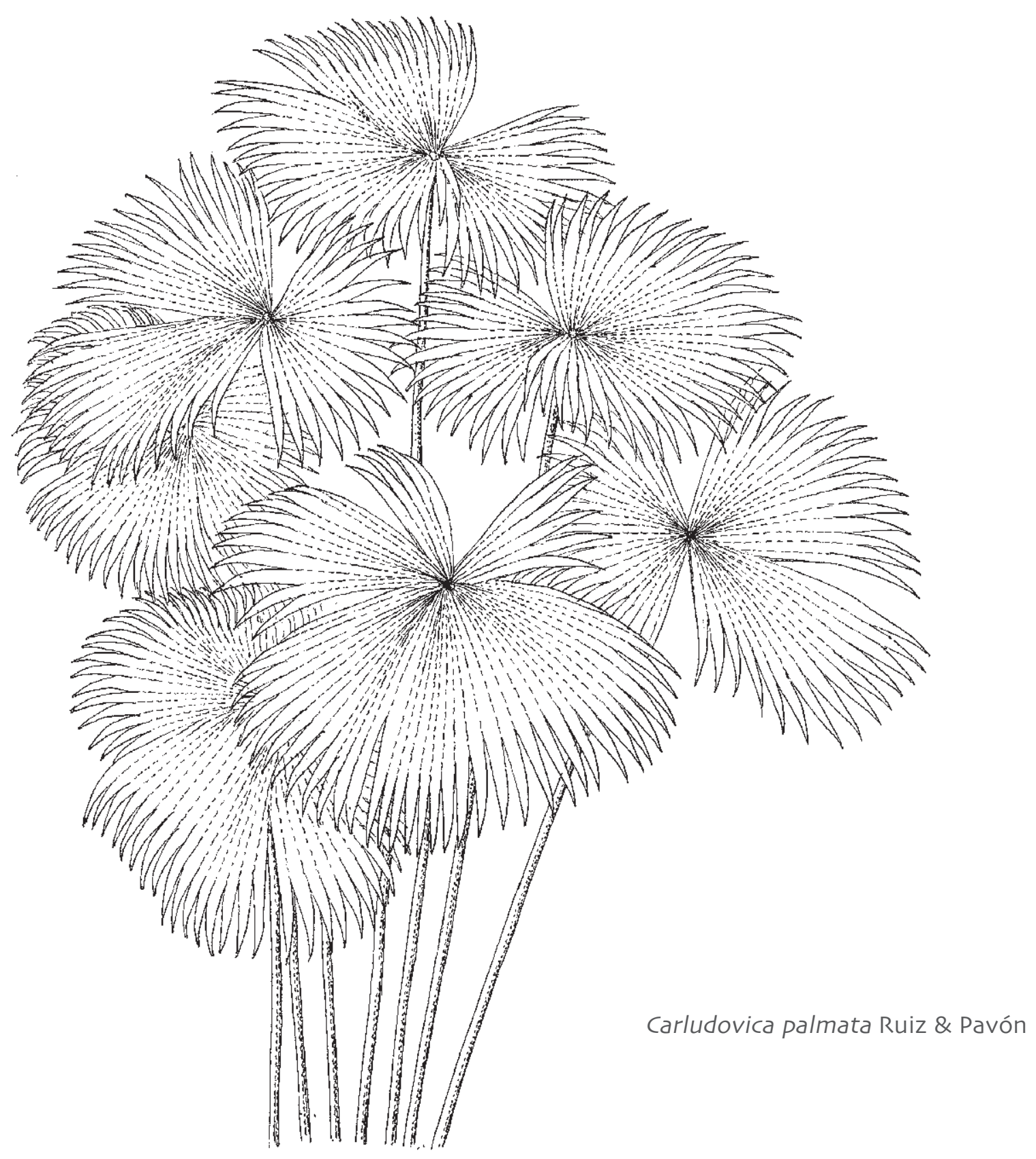

\section{Fibra de jipijapá, artesanatos}

Caso Boliviano apresentado por Erik Arancibia e Fausto López 


\section{A Bolívia tira o chapéu para a jipijapá}

Jipijapá (Caludovica palmata), uma espécie que parece uma palmeira e cresce silvestre* nas florestas tropicais e subtropicais da América do Sul e Central, tem se entrelaçado profundamente no dia-a-dia dos agricultores bolivianos. Das fibras brancas e finas dessa planta, também conhecida como bombonaça, se produz uma grande variedade de artigos incluindo o famoso chapéu panamá (veja o caso anterior sobre esse chapéu neste volume). Na verdade, o chapéu panamá surgiu no Equador, mas ganhou o seu nome da rota de comércio para a Europa, que passava pelo Panamá.

Os missionários jesuítas introduziram as técnicas de tecelagem para fazer chapéus e cestos na Bolívia em 1908. A iniciativa valeu a pena e, três anos depois, o explorador norueguês Erland Nordenskiold já observou um aumento da qualidade e dos modelos dos chapéus vindos da Bolívia. Com o tempo, os artesãos expandiram suas habilidades no processamento e manuseio das fibras da jipijapá e passaram a confeccionar também carteiras, pastas, figuras decorativas, e vários utensílios de mesa e cozinha.

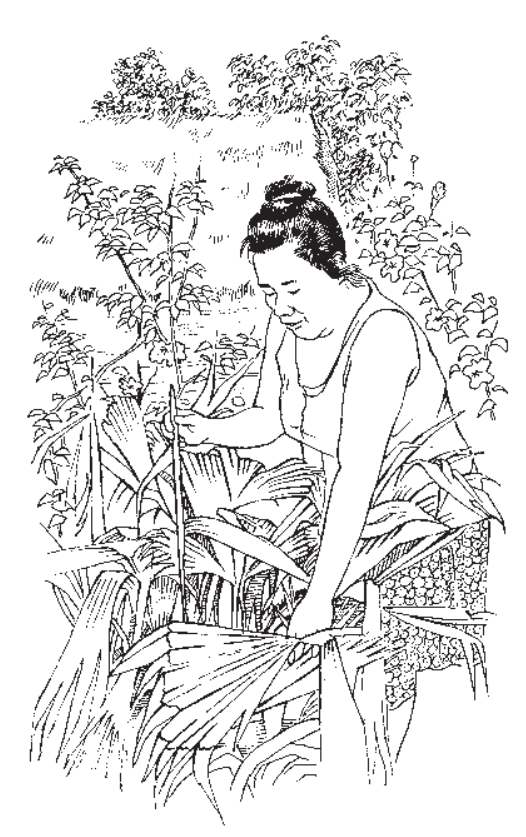

Mulher colhendo brotos ainda fechados de Jipijapá da base do caule da planta.

\section{O trabalho comunitário}

Hoje, o artesanato de jipijapá é produzido nas comunidades das planícies do nordeste da Bolívia por povos indígenas" nas cidades de Buenavista em Santa Cruz, San Borja em Beni e também por colonizadores em Buenavista e Chapare, em Cochabamba. Essas remotas comunidades vêm desenvolvendo relações mais fortes com o mundo exterior à medida que a manufatura do artesanato de jipijapá se expande.

Como resultado, alguns artesãos estão formando associaşões que dão suporte ao processo de comercialização. As principais incluem a organização Carmen Surutú, a Asociação de Artesãos de Galilea (Artegal) e a Associação de Tecelões de Palmeira de Ichilo. Esta última tem recebido assistência técnica do governo boliviano para a introdução de plantasões de jipijapá através do Centro de Investigaşão de Agricultura Tropical (CIAT). Carmen Surutú e Artegal são associacões de mulheres que produzem artesanato de jipijapá. A Artegal foi criada com a ajuda do Centro de Pesquisa Biológica de Beni, mas a Carmen Surutú não tem apoio externo e depende somente dos mercados locais para distribuir os seus produtos. Os tecelões de jipijapá têm apoio da Associação de Artesãos do Campo (Artecampo), uma organização nãogovernamental que dá apoio à manufatura de tecidos e outros artesanatos e proporciona diferentes canais de comercialização dentro da Bolívia. 


\section{A colheita dos brotos}

As plantas de jipijapá são nativas das florestas tropicais e subtropicais úmidas, mas também podem ser encontradas crescendo espontaneamente em lavouras, terras comunitárias, barrancas dos rios e ravinas. A jipijapá é geralmente colhida dos estoques nativos. A espécie raramente é cultivada na Bolívia porque os agricultores têm tido pouco sucesso em aumentar a baixa taxa de sobrevivência das plantas. Eles tentaram cultivá-las em plantacões, como monoculturas*, mas as plantas sentiram a falta de sombra e se desidrataram. Algumas plantas conseguiram se desenvolver, mas tinham folhas muito menores do que aquelas que crescem à sombra do dossel* da floresta. Os equatorianos, entretanto, tiveram mais sucesso no cultivo da jipijapá, conhecida naquele país como toquilha, e conseguiram estabelecer plantasões produtivas dessa planta.

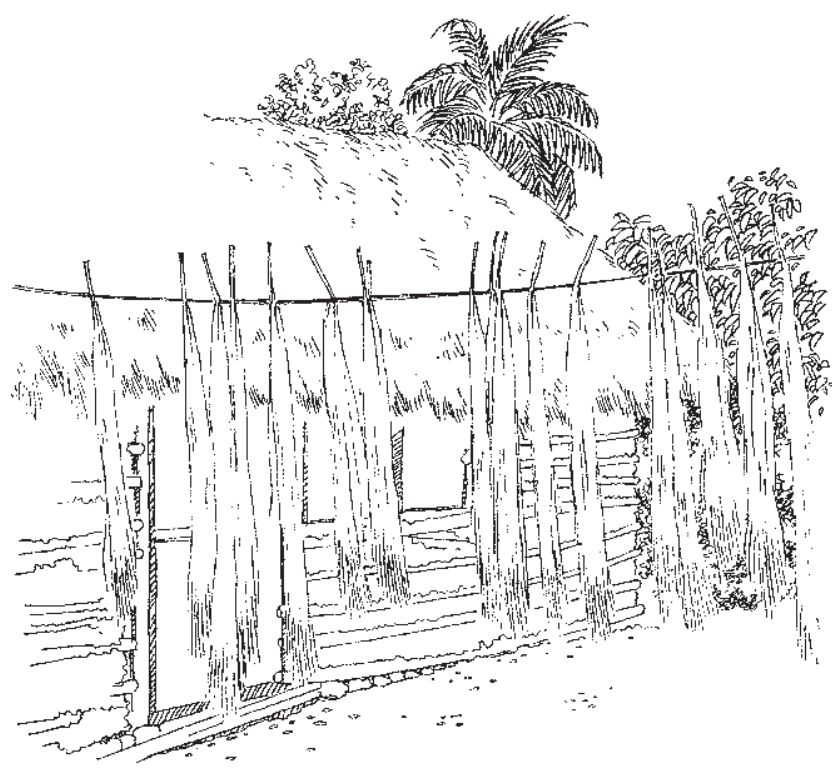

As fibras são penduradas ao sol por dois dias, e sua cor passa de amarelo para branco à medida que secam.

\section{Muitos passos até a perfeição}

O processamento das fibras de jipijapá envolve muitos passos. Os colhedores, em sua maioria homens, cortam os brotos nas plantações ou na floresta e os trazem em feixes para as suas vilas. Cada feixe pesa entre dois e três quilos e contém 12 a 14 folhas fechadas. O comprimento das folhas varia, mas a maioria tem cerca de um metro. As duas ou três folhas externas mais duras são separadas da parte mais grossa do broto e descartadas porque elas não servem para tecer. Um compasso de madeira, um osso fino ou uma agulha são usados para descascar essas camadas. O broto é então dividido ao meio, as folhas mais finas e estreitas são removidas, deixando somente as mais largas para tecer. Estas são fervidas por 10 minutos em um grande tacho com água contendo suco de limão e lavandina (um branqueador comercial). Depois, são penduradas ao sol por cerca de 20 minutos, antes de serem separadas umas das outras e permanecem penduradas durante toda a noite e o dia seguinte para assegurar que sequem completamente. Elas mudam de cor, de amarelo para branco, e nesse ponto estão prontas para serem tecidas. Recentemente, alguns artesãos passaram a tingir as fibras usando diferentes cores, que são combinadas durante o processo de tecelagem para conseguir lindos efeitos visuais.

Alguns colhedores de jipijapá também a tecem; outros vendem as fibras para artesãos, que com sua criatividade produzem vários artigos. Em San Borja, por exemplo, é comum 
os colhedores também tecerem as fibras, enquanto em Buenavista, em Santa Cruz, onde há cerca de 20 famílias produzindo artesanato de jipijapá, somente duas delas colhem os brotos, principalmente devido às longas distâncias que têm que vencer para chegar às florestas onde as plantas crescem.

A maioria do artesanato de jipijapá é vendida dentro da Bolívia, embora a associação de artesãos de Chapare, em Cochabamba, têm explorado o mercado de exportação. É difícil estimar o valor total da produção de jipijapá uma vez que a producão da matéria-prima é transformada em muitos produtos que são comercializados de muitas maneiras diferentes. Para uma família, a jipijapá pode representar entre 15 e 80 por cento da renda total, dependendo da distância ao mercado, do número de pessoas da família envolvidas na venda de jipijapá e se elas pertencem ou não a uma associação.

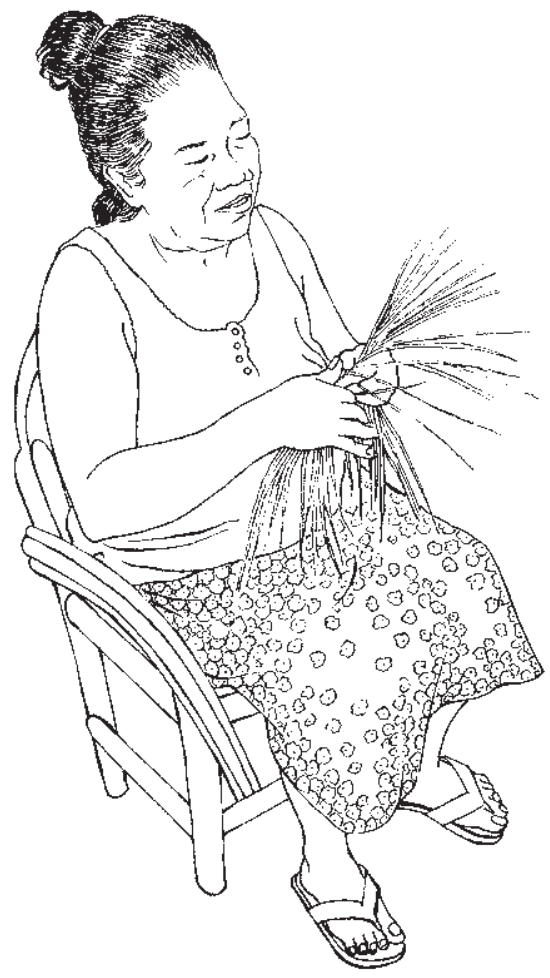

Uma mulher artesã começa a tecer as fibras secas de jipijapá para transformá-las em chapéus, cestos e muitos outros artigos de grande utilidade.

\section{Um futuro incerto}

Há dois fatores principais que afetam a produção de artesanato de jipijapá. Em algumas áreas, os brotos de jipijapá estão sendo colhidos mais rapidamente do que as plantas podem regenerá-los, o que está provocando a redução das populações nativas dessa planta na Bolívia. Além disso, quantidades muito grandes de brotos estão sendo removidas das plantas, diminuindo o número de folhas e conseqüentemente a quantidade de fotossíntese* que ocorre na planta, comprometendo a sua capacidade de se recuperar. Quase metade das populaşões originais de jipijapá bolivianas já desapareceu, principalmente devido às mudanças no uso da terra; as áreas de floresta estão sendo desmatadas para serem convertidas em pastagens para a criação de gado e em áreas agrícolas.

Outra ameaşa é a formasão de novas associasões criadas com apoio governamental ou externo. A capacitação para promover a produção de artesanato de jipijapá sem assegurar que exista uma demanda adequada para os artigos pode resultar em saturação do mercado e queda dos presos para colhedores e processadores. Esses fatores deverão ser levados em conta para garantir que as populacões de jipijapá possam sobreviver na Bolívia e continuem a fornecer benefícios para os colhedores e os tecelões que trabalham com essa fibra. 


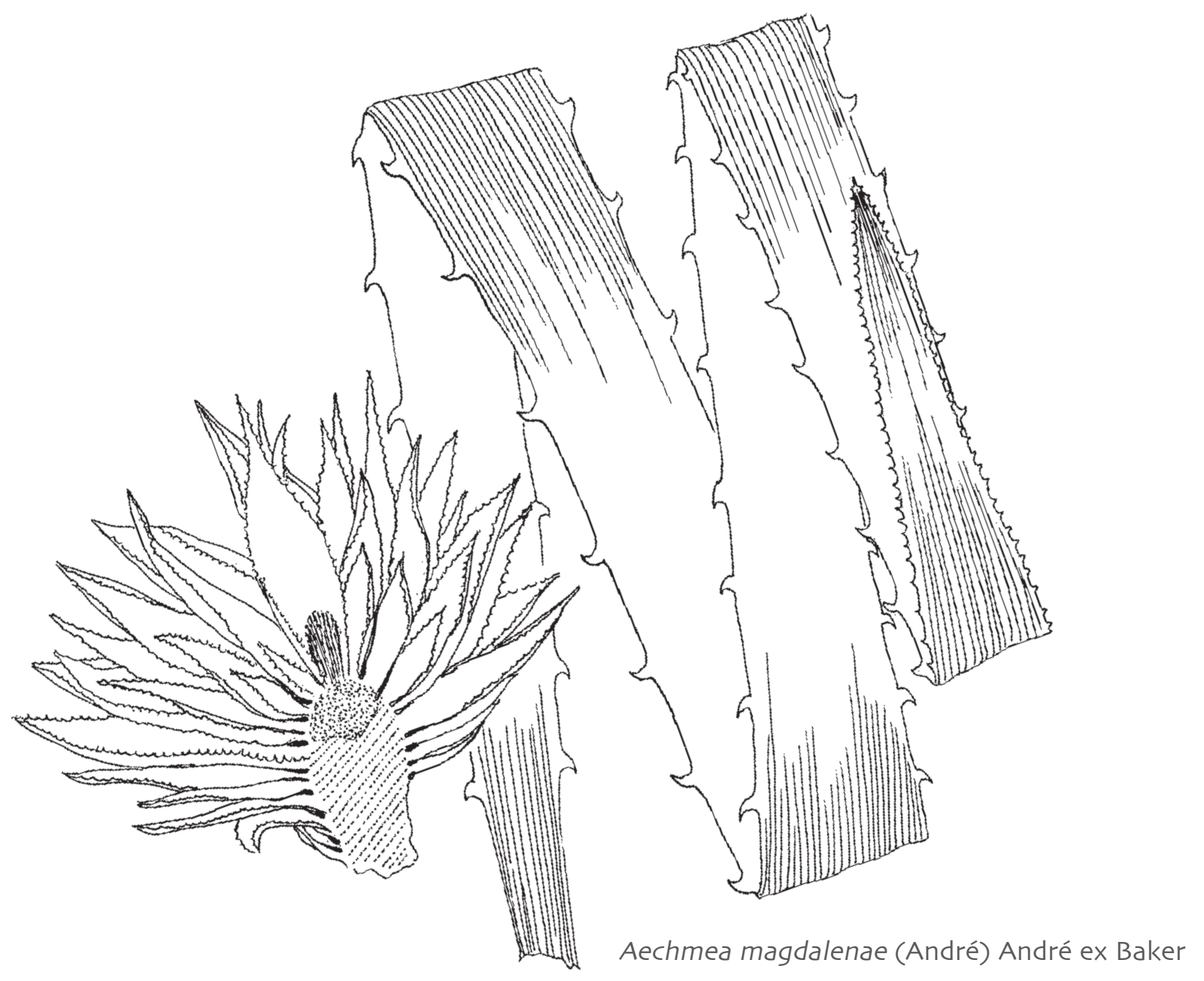

\section{Fibra de Pita, bordados}




\section{Pita: A fibra natural mais resistente do mundo renasce na onda da música}
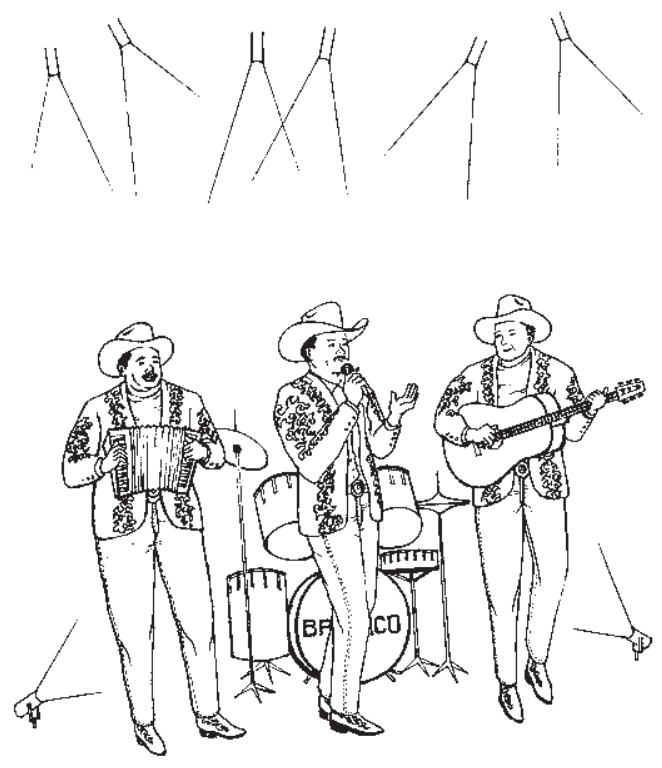

Acordeão e baixo a Onda Grupera, tocada por pequenas bandas que vestem lindas roupas e acessórios enfeitados com bordados de pita.

O renascimento da Onda Grupera, um fenômeno cultural e musical que se estende ao longo da fronteira entre o México e os Estados Unidos, tem preservado uma linha vital que conecta passado e presente: a arte secular do uso da pita, uma fibra vegetal tão brilhante e lisa como a seda, porém mais resistente e versátil e que estava em perigo de desaparecer. Uma reminiscência dos dias do charro (os cowboys mexicanos), os músicos da Onda Grupera vestem roupas de couro lindamente bordadas com pita. Antes substituída por outras fibras sintéticas, o fenômeno musical resgatou a importância da pita, que se tornou a mais valiosa e desejável fibra natural do país.

\section{Das redes de pesca para o mundo da moda}

A planta da pita (Aechmea magdalenae), uma bromélia também conhecida como ixtle, é nativa das florestas tropicais altas do sudeste do México. A fibra extraída das folhas espinhentas da (que podem atingir o comprimento de três metros) é excepcional por diversas razões. É comparável à seda em termos de tamanho, brilho e textura fina, mas tem maior resistência. Tradicionalmente, os grupos indígenas* chinantecos, lacandones e popolucas a usavam para confeccionar redes de pesca porque ela não encolhe nem perde a resistência na água. Tingida com índigo, era tecida para fazer redes duráveis que eram quase invisíveis debaixo da água. A fibra de pita também usada para amarrar pontas de flecha e confeccionar sapatos e objetos cerimoniais como abanadores de penas de faisão.

A partir dos anos 1960, no auge das fibras sintéticas, o uso da pita esteve a ponto de ser abandonado. Felizmente, alguns artesãos do norte do México continuaram a se especializar no uso da fibra para bordar artigos de couro como cintos, botas e selas de cavalo. Quando o estilo musical da Onda Grupera tornou-se popular, as jaquetas, chapéus, cintos de botas de cowboy encontraram um fabuloso mercado. Por causa desse renascimento cultural e musical, a demanda por pita aumentou dramaticamente, assim como os seus presos, que superaram o do linho e da seda, chegando a valer 1000 pesos mexicanos por quilo (93 dólares). 
A pita cresce principalmente nos três estados do sudeste do México: na região Chinantla de Oaxaca, nas florestas de Lacandona em Chiapas e em diversas e pequenas áreas de Veracruz, onde resistem os relictos de floresta. Existem também populascões silvestres na América Central e na Colômbia, mas essas populações ainda não foram exploradas para a produção de fibra. As plantas crescem em densos fragmentos de florestas perenifólias*, principalmente nos locais próximos aos córregos, rios e áreas alagadas. Quando atingem a _idade de seis anos, elas produzem lindas flores comestíveis e então produzem sementes, antes de morrerem.

\section{Mais lucrativa que café e gado}

Um colhedor remove as bordas espinhentas das folhas, preparando-as para as mulheres extraírem as fibras.
Antes dos anos 1990, comunidades indígenas e de mestizos* do sudeste do país extraíam a fibra de pita de populações naturais de plantas. O rápido aumento da demanda encorajou os agricultores a iniciarem a domesticaşão da espécie, colhendo brotos das áreas agrícolas em pousio*, plantações de café e fragmentos florestais. As folhas são colhidas de plantas com cerca de três anos de idade, um trabalho realizado pelos homens. Os colhedores recolhem até 250 folhas de cada vez, se eles têm animais para transportar a carga. Para obter 1 quilo de fibra são necessárias aproximadamente 250 a 350 folhas, dependendo do seu tamanho. Um hectare de floresta pode produzir 15 a 25 quilos de fibra por ano, que representam uma renda de 4500 a 10000 pesos mexicanos (430 a 930 dólares). Essa renda é superior àquela que os produtores de café e criadores de gado podem ganhar na mesma área de terra. A magnitude dessa renda também tornou a pita um elemento chave na conservacão dos remanescentes florestais e áreas de pousio do sudeste do México, ameaçados pela expansão das fazendas de gado e da agricultura. A produção anual de pita no país é estimada entre 30 e 40 toneladas.

A fibra de pita é extraída usando-se uma técnica indígena, raspando-se as folhas sobre um tronco de madeira com uma lâmina feita do caule de palmeira ou bambu. As fibras são então lavadas várias vezes com sabão e suco de limão, batidas para remover impurezas e secas ao sol. Nesse ponto, as limpas fibras brancas são meticulosamente penteadas e classificadas de acordo com o tamanho. O processamento de 10 quilos de fibra requer o trabalho de duas ou três pessoas durante 15 dias. Os seleiros transformam as fibras em fios enrolando conjuntos de fibra em volta dos seus joelhos. Com os fios, bordam à mão peças de couro com motivos pré-hispânicos e as usam para produzir cintos, selas, botas, carteiras e outros artigos masculinos e femininos.

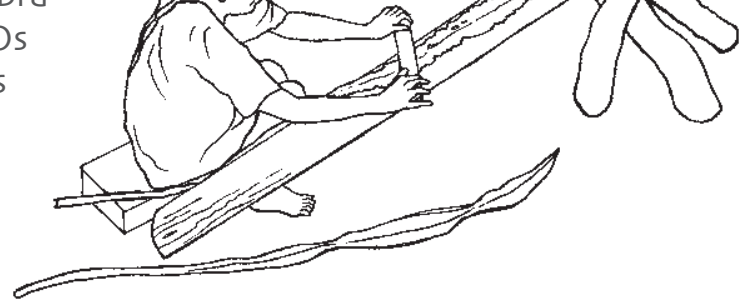

As folhas de pita são raspadas sobre um tronco para separar as fibras. 


\section{A arte dos seleiros e prisioneiros}

Os colhedores indígenas do sudeste do México vendem a pita bruta para os revendedores, que fazem o processamento da fibra. Eles adquirem a fibra pelo preso de 300 a 400 pesos mexicanos ( 28 a 38 dólares) por quilo e a revendem branqueada e penteada para os artesãos e seleiros do norte do país por 600 a 800 pesos mexicanos (55 a 75 dólares) por quilo. Embora exista um grande número de artesãos de pita, a maior concentração deles está na pequena cidade de Colotlán, no estado de Jalisco. Ali, as empresas altamente desenvolvidas de artesãos empregam mais de 1000 bordadores. Prisioneiros nas penitenciárias mexicanas também produzem muitos dos artigos comprados pelos fãs da música.

Os artigos de pita têm um alto preşo de mercado. Alguns cintos piteados são vendidos por mais de 3000 pesos mexicanos (280 dólares) e as selas bordadas à mão mais luxuosas podem custar mais de 9500 pesos mexicanos (900 dólares). Dos anos 1990 em diante, os artesãos também passaram produzir uma linha de produtos mais baratos, gerando vendas para um crescente número de consumidores no México, Estados Unidos e, mais recentemente, na Espanha. Hoje, existe um processo de organização da cadeia de produção e comercialização, entre fornecedores e consumidores, através da formação do Conselho de Organizacões de Produtores de Pita da Floresta (Conppita) em Oaxaca, Veracruz e Chiapas e do Conselho Regulador da Arte do Piteado, constituído por artesãos da região de Colotlán.

\section{Novos usos à vista}

A demanda por pita cresceu consideravelmente na década de 1990, mas os artesãos estão notando que o mercado declinou levemente por conta da competição dos artigos feitos com couro de avestruz e outras peles exóticas. Contudo, o uso dos cinturões "piteados" está relativamente bem consolidado no modo de vestir dos mexicanos que vivem no país e nos Estados Unidos, o que garante a preservação desse artesanato. Com o objetivo de desenvolver novos usos para a esta excepcional fibra, existe atualmente um processo de colaboração entre produtores, organizasões não-governamentais e o governo mexicano para identificar novas oportunidades, entre as quais se encontra a fabricacão de tecidos e papel com a folha raspada da pita.

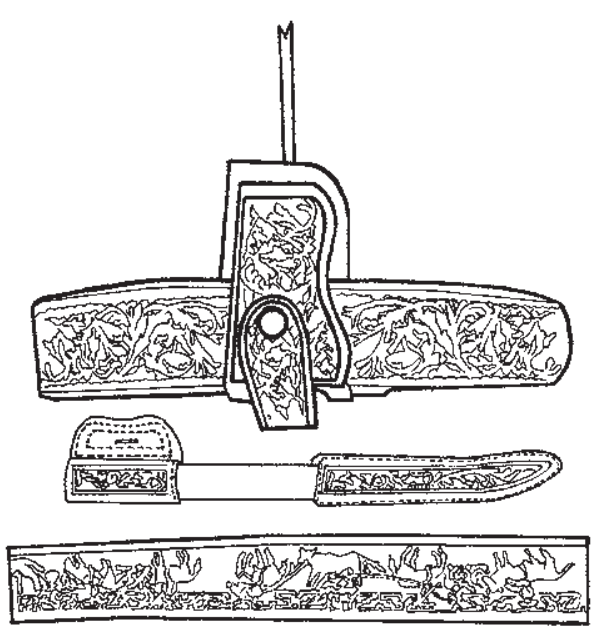

Charros (cowboys) do México vestem uma indumentária tradicional bordada com fibra de pita. 


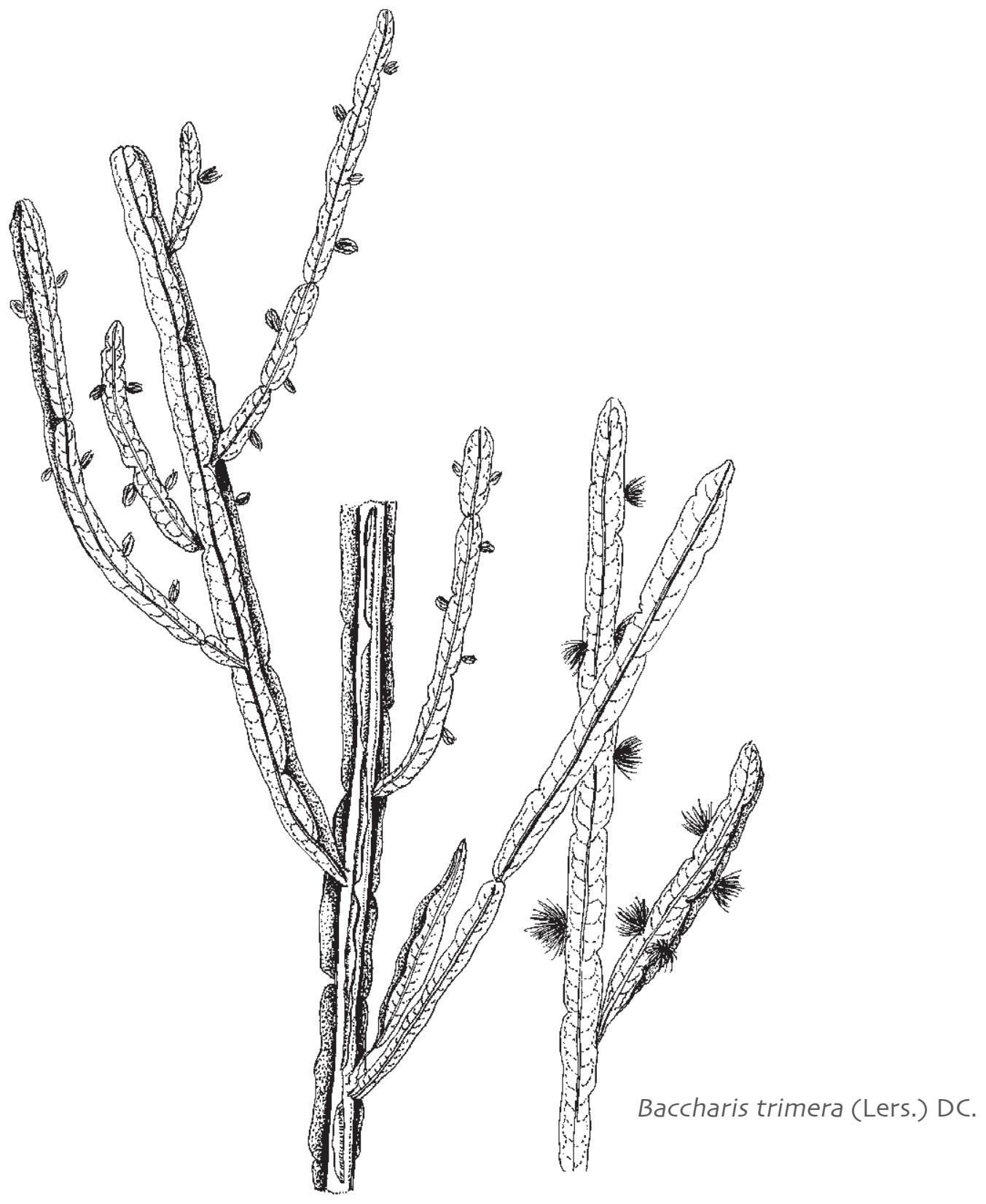

\section{Carqueja, folhas medicinais}

Caso brasileiro apresentado por Walter Steenbock 


\section{Carqueja: Remédio do planalto brasileiro}

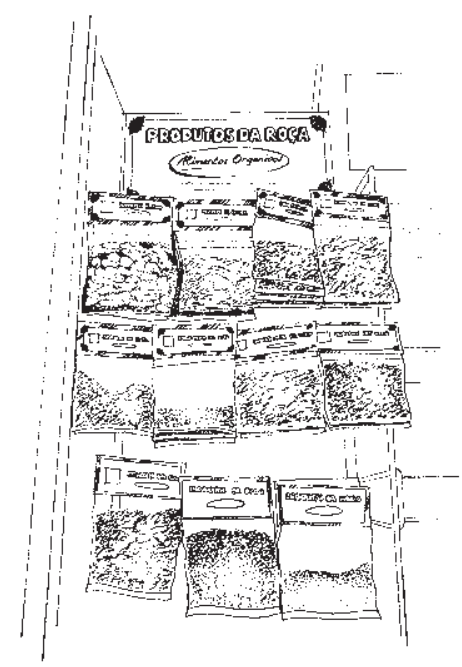

Diferentes ervas, incluindo a carqueja, são produzidas pela cooperativa de Banhado Grande, no centro do Paraná, e comercializados com o nome de Produtos da Rosa.

O planalto do sul do Brasil é uma região maravilhosa com as suas majestosas florestas com araucárias* e campos nativos*. A floresta emprestou esse nome do pinheiro brasileiro ou pinheiro-do-paraná (Araucaria angustifolia), uma árvore que atinge altura e diâmetro do tronco* impressionantes e que apresenta uma arquitetura muito particular. Mas o planalto é notável não somente pelas suas belíssimas paisagens onduladas - ele também abriga uma grande diversidade de espécies de plantas nativas, muitas das quais têm propriedades medicinais muito valiosas para as comunidades rurais da região.

O solo e as condições climáticas em grande parte dessa região são limitasões para a agricultura comercial. Em muitas das comunidades locais, a coleta de produtos florestais não-madeireiros (incluindo o pinhão, a erva-mate e as plantas medicinais) tornou-se uma atividade econômica importante. Entre as plantas medicinais, uma das principais espécies colhidas é a carqueja (Baccharis trimera), uma erva popularmente usada no tratamento de problemas digestivos e da obesidade.

O uso da carqueja tem sido estudado na região central do Paraná, no sul do Brasil, onde essa planta é abundante. Os habitantes da região constituem uma rica mistura cultural de povos indígenas*, caboclos e descendentes de imigrantes italianos, alemães e poloneses. Essa riqueza cultural é refletida no grande número de plantas medicinais usadas e na considerável base de conhecimentos relacionados às propriedades terapêuticas dessas plantas que eles desenvolveram ao longo dos séculos.

\section{As mulheres tomam a dianteira}

Nos anos 1980, grupos de mulheres associadas a organizações rurais na região central do Paraná organizaram uma série de reuniões para discutir o papel das plantas medicinais locais no tratamento de doenças. Elas trocaram idéias e receitas, e compartilharam o seu conhecimento sobre o uso das plantas como terapia alternativa. Logo reconheceram também que, além do seu valor medicinal, o potencial econômico dessas plantas representava uma grande oportunidade para suas famílias. Durante as últimas décadas, vários projetos nessa região buscaram proteger esse conhecimento tradicional e promover o manejo, cultivo e uso de espécies de plantas nativas".

Hoje, os produtos dessas plantas são bem mais conhecidos e mais populares tanto dentro quanto fora do Paraná. Além de tratar enfermidades, as plantas medicinais assumiram um 
novo papel no desenvolvimento local, tornando-se uma fonte de renda para muitas famílias rurais. Com resultado, novos mercados se abriram, e produtos derivados das plantas do Paraná são agora comercializados em todo o Brasil.

\section{O crescimento do comércio de chás medicinais}

Pelas leis brasileiras, cada produto derivado de plantas medicinais é classificado ou como alimento ou como remédio. A carqueja foi classificada como alimento, o que facilita o seu processamento e venda pelos agricultores. Na comunidade de Banhado Grande, no centro do Paraná, uma cooperativa foi formada na época dos encontros de mulheres dos anos 1980. Trabalhando com a Fundação Rureco, uma organização nãogovernamental que dá assistência a famílias de agricultores e associacões, criaram o Projeto Florestas Medicinais. Essa iniciativa multi-institucional, que tem recebido suporte financeiro do governo brasileiro e de organizacões externas, cresceu e envolveu cooperativas similares na região.

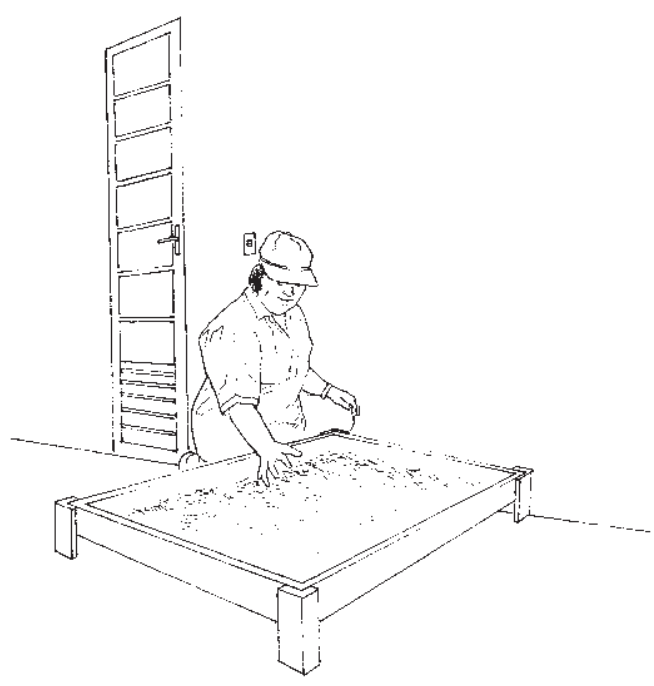

Depois que as folhas da carqueja são picadas e secas, elas são empacotadas em sacos plásticos e estão prontas para a comercialização.

Para as famílias rurais das comunidades envolvidas, a produção de plantas medicinais pode representar 30 a 40 por cento da sua renda total. Nessas comunidades, além da colheita de plantas como a carqueja, uma selecão de chás medicinais também está sendo produzida com o nome de Produtos da Rosa. Esses produtos são vendidos em supermercados, farmácias e outros pontos de comércio no Paraná e no restante do país. A profusão de chás começou com o modesto volume inicial de 200 pacotes por mês no início de 1999, e saltou para 15000 pacotes por mês no final de 2000 . Atualmente, a produção é de cerca de 25000 pacotes e a demanda continua a crescer constantemente.

A erva carqueja é um dos fitoterápicos de maior sucesso comercial do mercado de plantas medicinais do sul do Brasil. Esse pequeno arbusto é comum no centro do Paraná, onde cresce principalmente nos campos e na borda das florestas com araucárias, sendo encontrada em pequenas "ilhas de carqueja". Além de colherem as plantas na natureza, 17 comunidades rurais estão envolvidas no cultivo e processamento da carqueja e de outras plantas medicinais, usando técnicas da agricultura orgânica*.

\section{Colhendo para o futuro}

Tanto homens quanto mulheres colhem e processam a carqueja. As folhas são cortadas com faca ou foice, aproximadamente 5 centímetros acima do solo. As plantas crescem abundantemente e podem ser encontradas em densidades de cerca de 1 ooo plantas por

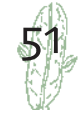




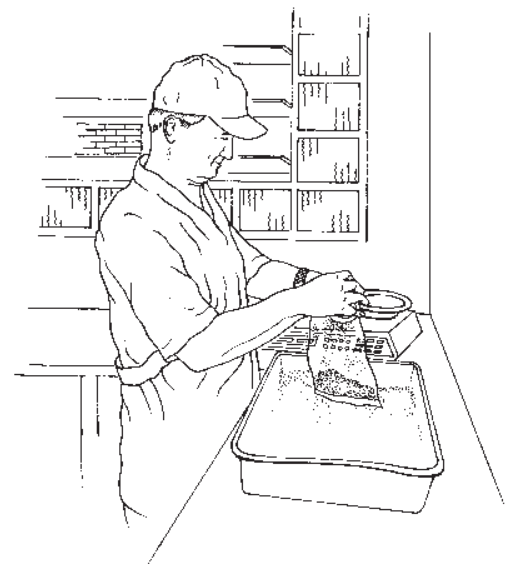

A carqueja e outras plantas medicinais são vendidas em mercados locais, bem como em drogarias e supermercados em todo o Brasil.

hectare. As famílias de agricultores locais geralmente têm propriedades com cerca de 40 hectares e a maioria delas colhe plantas medicinais de suas próprias terras.

Como o principal período de coleta de carqueja ocorre um pouco antes do florescimento das plantas, ou seja, antes da produção de sementes para a reprodução natural da espécie, a colheita excessiva pode ter um efeito negativo nas populasões dessa planta. Desde 1999, a cooperativa de Banhado Grande vem implementando diferentes estratégias, baseadas na participação dos agricultores, para proteger e estimular a regeneração de plântulas de carqueja. Essa medida está contribuindo para a manutencão de muitas plantas de diferentes idades, espalhadas em diversas áreas. Experimentos conduzidos em 1999 e 2000 mostraram que deixar "ilhas intocadas" de carqueja como uma forma de "banco de sementes" facilita a regeneração e ajuda a garantir os estoques futuros - uma iniciativa fundamental em face da crescente demanda.

Logo depois da colheita, as plantas são levadas para a cooperativa, onde são picadas em pequenos pedaços e secadas. A carqueja picada é colocada sobre panos de tule e secas ao sol, dentro de estufas construídas com madeira. Quando a intensidade da energia solar diminui, um aquecedor elétrico é usado para manter a temperatura perto de 35 ㄷ. Outras plantas medicinais também são processadas usando essa técnica simples. Depois de secas, as ervas são despachadas para uma unidade central onde são empacotadas. Essa associação de famílias de agricultores realiza todo o trabalho de produção e comercialização, evitando a intervenção de intermediários. Como resultado, os agricultores associados do Projeto Florestas Medicinais recebem precos três vezes maiores que os produtores de carqueja de outros lugares. As companhias atacadistas pagam aos outros agricultores, em média, um real ( 0,5 dólares) por quilo de carqueja seca, mas sem os atravessadores os agricultores que fornecem a erva para a cooperativa recebem cerca de três reais (1,50 dólares) por quilo.

\section{A participação da comunidade mostra o caminho}

Como a demanda por plantas medicinais continua a crescer, um dos desafios dos habitantes locais no centro do Paraná é manter uma produção sustentável de matéria-prima organicamente produzida. Outro objetivo é manter o controle local sobre o sistema de produção e comercialização. As comunidades estão percebendo quais são os fatores chaves para alavancar o desenvolvimento local. Os agricultores reconhecem que a participação das mulheres, o envolvimento da comunidade, a conservação dos recursos naturais, e a administração própria do processo de produção são elementos críticos do seu sucesso. 


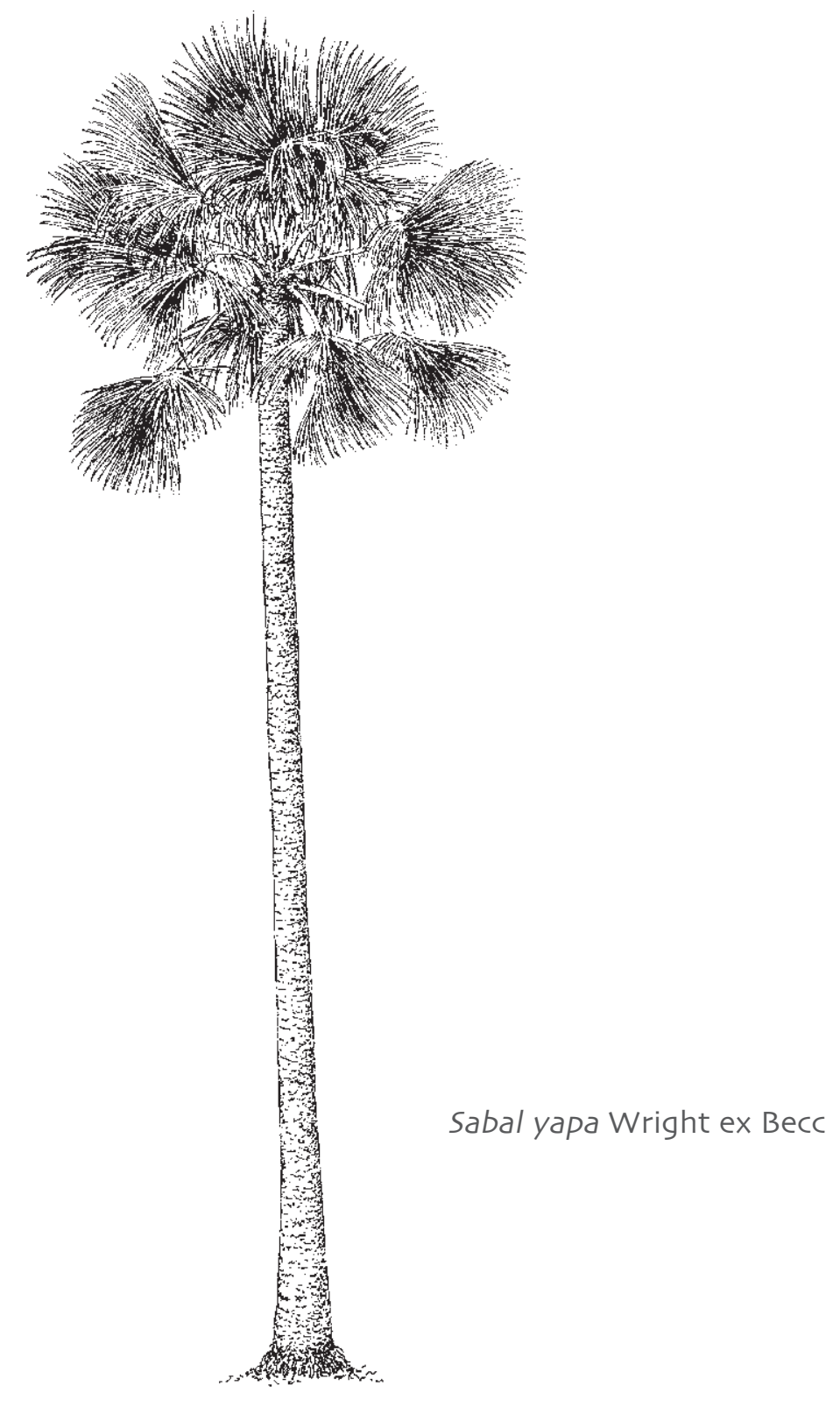

\section{Palma de Guano, folhas para telhados}

Caso mexicano apresentado por Javier Caballero, María Teresa Pulido e Andrea Martinez-Ballesté 


\section{Palmeira de Guano: Séculos de sombra, dos maias aos turistas de hoje}

Bem antes da chegada dos colonizadores espanhóis, a palmeira de guano (Sabal yapa) era fundamental na vida dos povos maia que habitavam o estado de Quintana Roo, no sul do México. Essa palmeira tem dado aos maias alimento, remédio, comida para os animais e um resistente material para a construção do telhado de suas casas. O nome maia para a palmeira (xa'an) quer dizer "aquela que dá sombra", talvez em alusão não somente à sombra que a palmeira dá, mas também uma referência à sombra dos telhados que são construídos com as sua frondes. Desde os anos 1970, as mesmas palmeiras que deram abrigo aos maias ancestrais têm fornecido refrescante sombra aos turistas que se confortam nos quiosques dos hotéis de luxo das praias de Cancún, Cozumel, Playa del Carmen e Tulum, no Caribe mexicano.

As palmeiras de guano são comuns em florestas tropicais áridas e também se desenvolvem bem em áreas onde a floresta original foi cortada. As palmeiras são deixadas para que cresçam nas terras que foram desmatadas para o cultivo do milho, de modo que os agricultores possam continuar a colher as suas folhas. Apesar das áreas serem queimadas para preparar o terreno para o plantio, sempre há palmeiras resistentes que sobrevivem. Permitindo que as palmeiras cresçam junto com as plantas cultivadas, os agricultores Ihes dão oportunidade

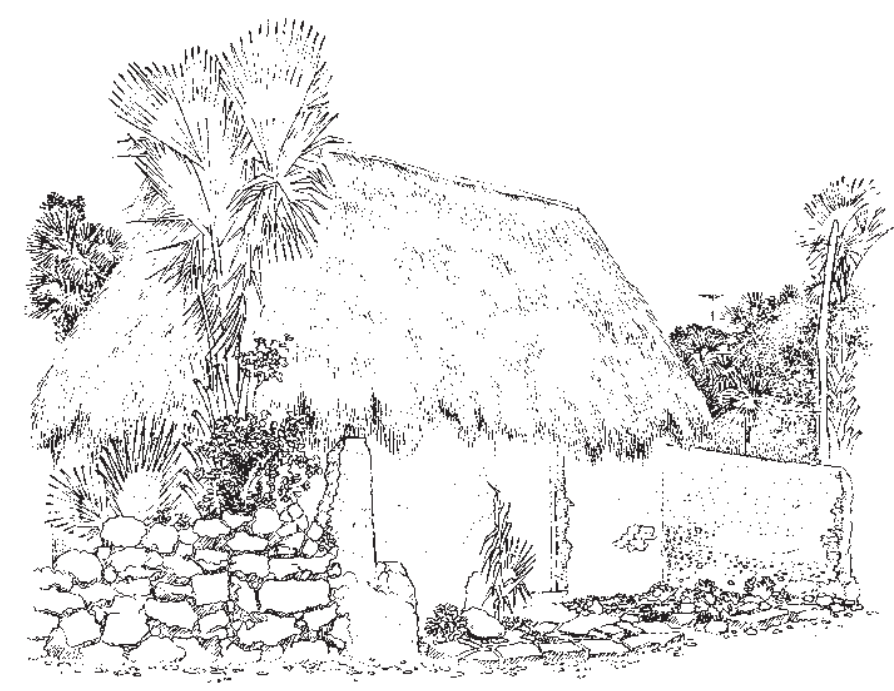

Uma típica casa rural com um telhado feito com folhas da palmeira de guano. para se desenvolverem permanentemente em áreas usadas temporariamente para agricultura. Essa prática é indispensável para o uso ecologicamente sustentável* da espécie, que pode viver até 100 anos.

\section{Os coletores ganham a vida com as palmeiras}

As palmeiras de guano podem ter uma altura de até 20 metros, mas por medida de segurança os colhedores somente colhem folhas daquelas que têm menos de oito metros. Para garantir a sobrevivência das palmeiras, os colhedores coletam suas frondes com sabedoria. Mesmo depois de uma suada escalada até o topo da palmeira, eles têm o cuidado de cortar somente três ou quatro folhas. 


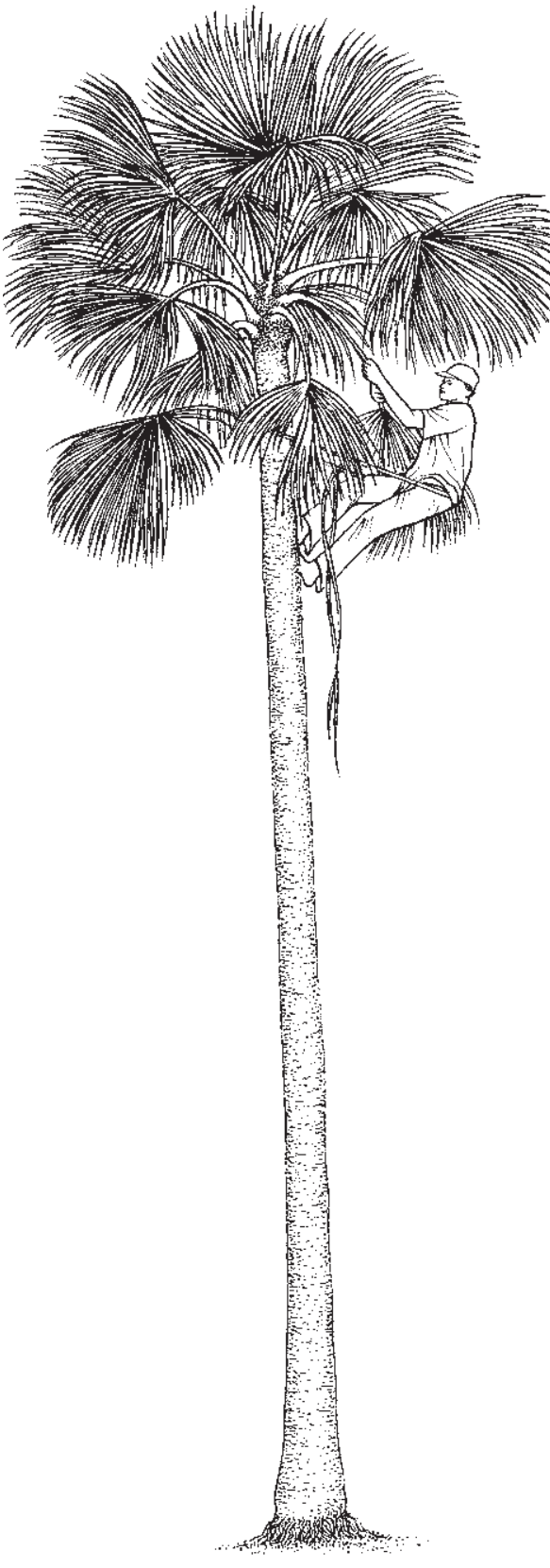

Um colhedor trepa numa palmeira de guano, com um corda em volta da cintura, e corta as três ou quatro folhas.
Usando um facão, cortam o pecíolo* das frondes da palmeira tão próximo quanto possível do tronco.

Trabalhando duro um dia inteiro um colhedor pode cortar cerca de 200 folhas. Quando a colheita é feita para fins comerciais, o trabalho é feito em grupos de quatro a dez pessoas. Após a colheita, as folhas são amarradas em feixes de 20 a 50 unidades, que são carregados nas costas ou em bicicletas até uma estrada, onde os transportadores ou intermediários as coletam.

As frondes de palmeira de guano podem ser colhidas durante todo o ano. Durante a estação seca as folhas podem durar até cinco meses antes de serem usadas nos telhados, mas na estação das chuvas elas precisam ser secas ao sol e usadas em até cinco dias. Por causa disso, a colheita é geralmente feita durante os meses secos, entre fevereiro e abril, coincidindo também com a época em que há menos atividades agrícolas. Entretanto, se um revendedor encomenda folhas em outra época do ano, os colhedores não rejeitam o trabalho.

\section{Novos mercados para um recurso tradicional}

As folhas da palmeira são vendidas de diferentes maneiras. Alguns comerciantes compram as folhas diretamente dos ejidos" e as vendem para as companhias construtoras que trabalham com turismo. Hotéis e restaurantes internacionais de luxo contratam empresas de construção para comprarem as folhas e construírem os quiosques e cabanas. Em alguns casos, os próprios trabalhadores especializados nessa arte, conhecidos como palaperos, vão até os ejidos e compram as folhas. Geralmente, eles também compram a madeira necessária para construir as tradicionais cabanas rústicas de palha ou palapas.

O preso das folhas varia com o custo do transporte e o pagamento da licença para a colheita. Nos ejidos, os colhedores recebem aproximadamente 1,50 pesos mexicanos ( 0,14 dólares) por folha, mas os consumidores finais podem pagar pelas folhas até três vezes essa quantia, ou seja, cerca de 4,50 pesos mexicanos ( 0,42 dólares). Em um único ano, um ejidatario* envolvido nesta atividade pode ganhar até 2100 pesos mexicanos (200 dólares) que embora seja uma modesta quantia é muito bem-vinda, porque chega numa época do ano em que as culturas ainda não estão prontas para serem colhidas. Na Península de Yucatán, a comercialização de folhas de guano dos últimos quatro anos gerou uma renda total perto de 2375000 de pesos mexicanos (226 190 dólares), incluindo a venda de folhas de Sabal yapa, S.mexicana, S. mauritiiformis e possivelmente S. gretheriae. 
No estado de Quintana Roo há cerca de oito ejidos que vendem folhas de guano. Esses centros são afiliados a organizações não-governamentais que fornecem assistência técnica e coordenam a exploração e comercialização das folhas. Entretanto, os ejidatarios necessitam maior orientação governamental para realizar um estudo técnico que Ihes permita obter as autorizações para exploração. Isso possibilitaria que uma maior parte do benefício econômico ficasse em suas mãos.

\section{Os ventos da mudança}

Como os povos maias antes deles, os agricultores em toda a Península de Yucatán continuam a usar as folhas de guano para fazer o telhado das suas casas. A demanda de folhas dos hotéis de luxo e a indústria do turismo, entretanto, têm decrescido recentemente. Em parte, isso pode ser devido à substituição das folhas de guano por gramíneas. Embora seja mais trabalhoso fazer coberturas com capins, os construtores gostam da aparência mais lisa que dão ao telhado; aos seus olhos, uma aparência de "paraíso tropical". Os palaperos notam que os telhados feitos de capim são mais caros tanto em termos trabalho quanto de dinheiro, e que eles não duram tanto quanto os telhados de guano. Os telhados construídos com as grandes frondes* ou folhas da palmeira de guano duram até 15 anos, embora os telhados na zona turística sejam trocados a cada três anos por razões estéticas.

Durante os últimos seis anos o governo mexicano aprovou novas leis ambientais para regular o manejo de recursos florestais, incluindo as folhas de guano. Essas regulamentasões são generalistas a ponto de dificultar a sua implementação. Entretanto, no caso da palmeira de guano, a regras oficiais poderiam contribuir positivamente para controlar a colheita e prevenir a superexploração desse valioso recurso.

Os telhados de folhas da palmeira de guano, tradicionalmente usadas para abrigar os povos maias, agora proporcionam sombra para os turistas do Caribe mexicano.

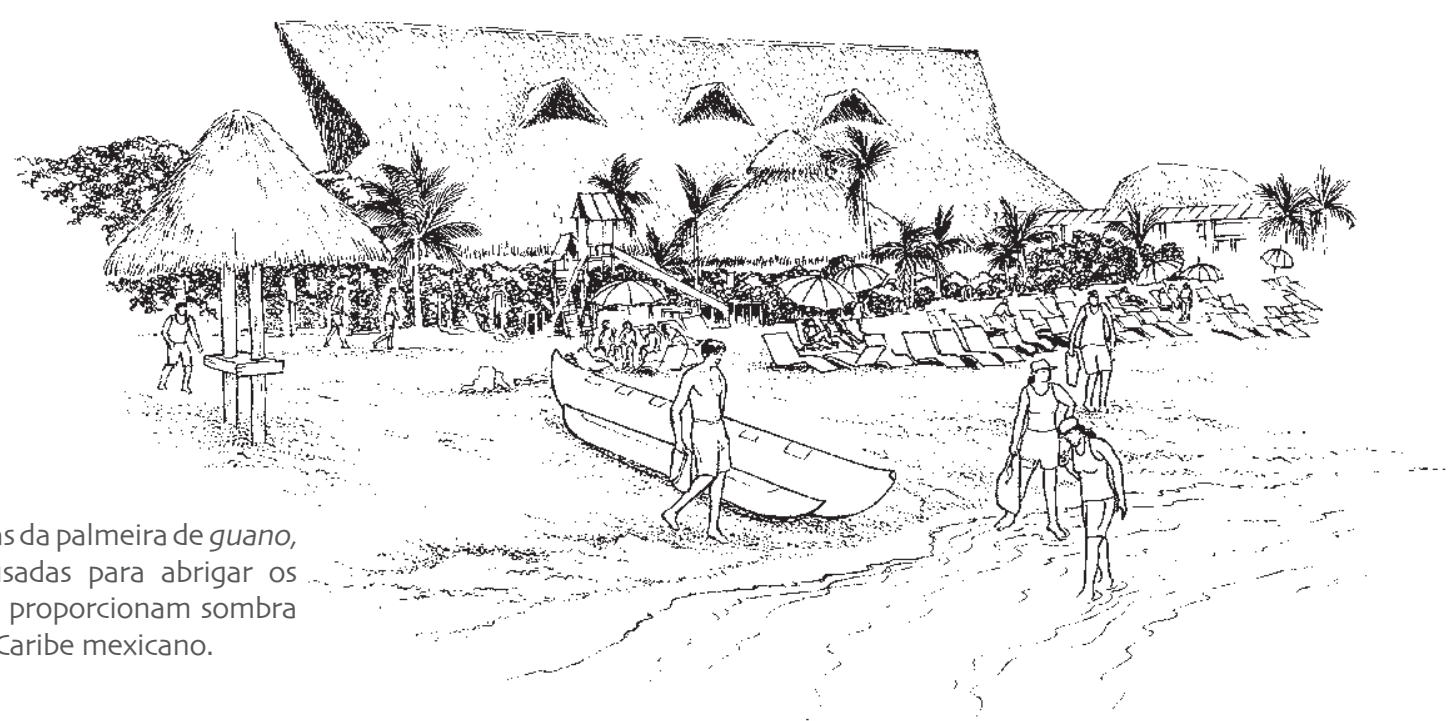




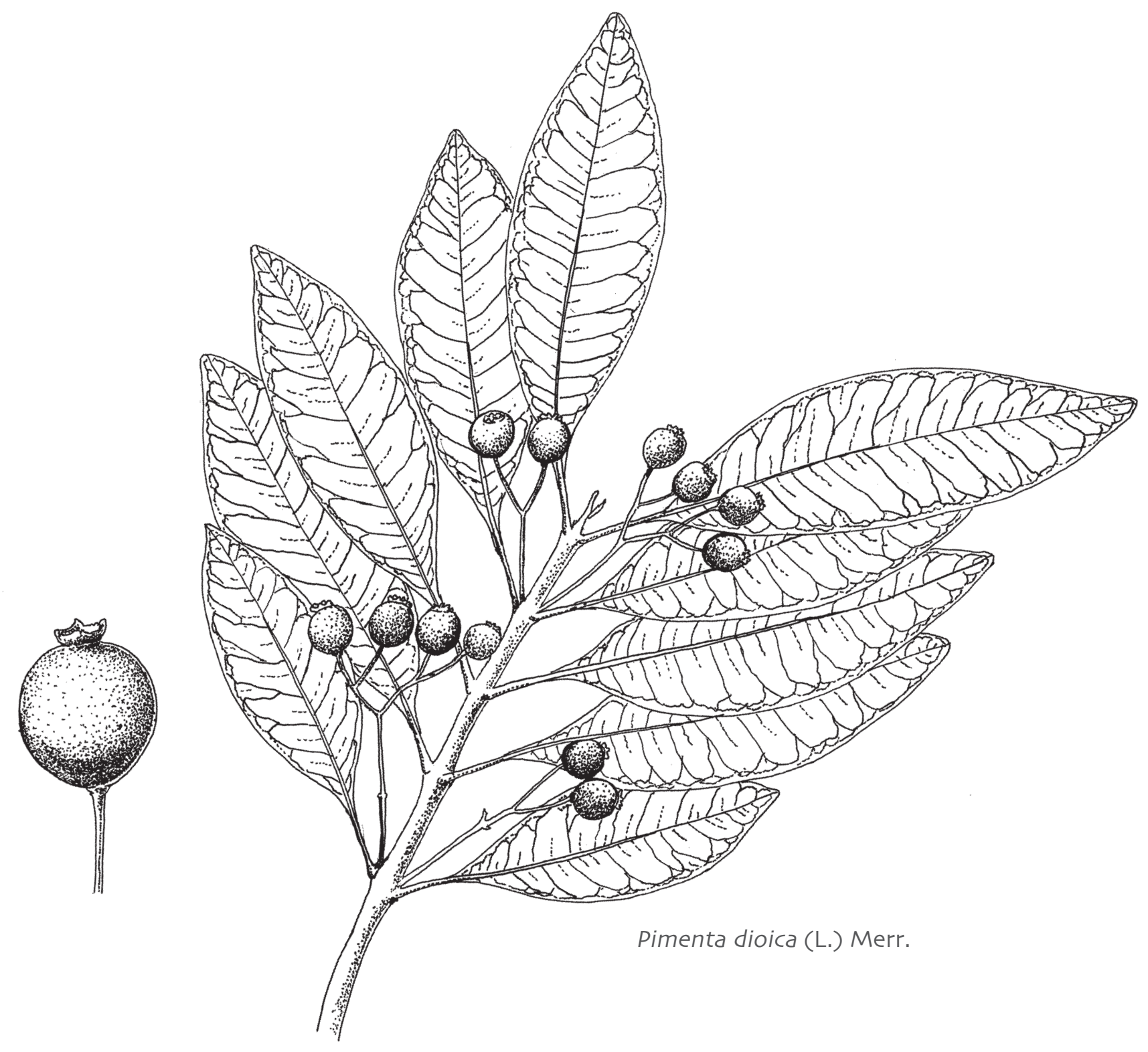

\section{Pimenta-da-jamaica, condimento}

Caso mexicano apresentado por Miguel Angel Martinez Alfaro, Virginia Evangelista Oliva, Myrna Mendoza Cruz, Cristina Mapes e Francisco Basurto Peña 


\section{Pimenta-da-jamaica: O sabor do México}

Você sabe de onde vem esse condimento que dá que à comida aquele distinto sabor picante e adocicado que delicia gente de todo o mundo? A pimenta-da-jamaica é similar à pimenta-doreino mas tem sabor e aroma mais doce. Tirado da pimenteira (Pimenta dioica), o sabor vem dos frutos secos e moídos, que à primeira vista parecem pequenas bagas verdes fortemente perfumadas. Além do condimento, das bagas secas também é extraído um óleo essencial usado na indústria farmacêutica, de cosméticos e alimentar.

\section{Uma longa história}

A pimenteira cresce em vários países da América Central e no México, onde a sua história de uso comesou muito antes da chegada dos espanhóis. Conhecida no México como pimienta gorda e como allspice em inglês, historicamente a pimenteira tem dado um extraordinário presente em termos de sabor, tanto ao velho quanto ao novo mundo. Nos tempos pré-hispânicos, os povos indígenas* do México usavam as "baguinhas" dessa pimenteira, que eram chamadas de xocoxóchitl, para temperar a sua comida, e como um ingrediente na sua medicina tradicional. Os colonizadores espanhóis rapidamente adotaram o tempero local e passaram a usá-lo na sua culinária também - misturando condimentos nativos*, cultivares* e frutas às diferentes plantas da sua terra natal. Eles chamaram a pimenta local de 'malagueta' ou 'pimenta tabasco', que num piscar de olhos tornou-se um dos principais produtos comerciais nessa nova colônia espanhola.

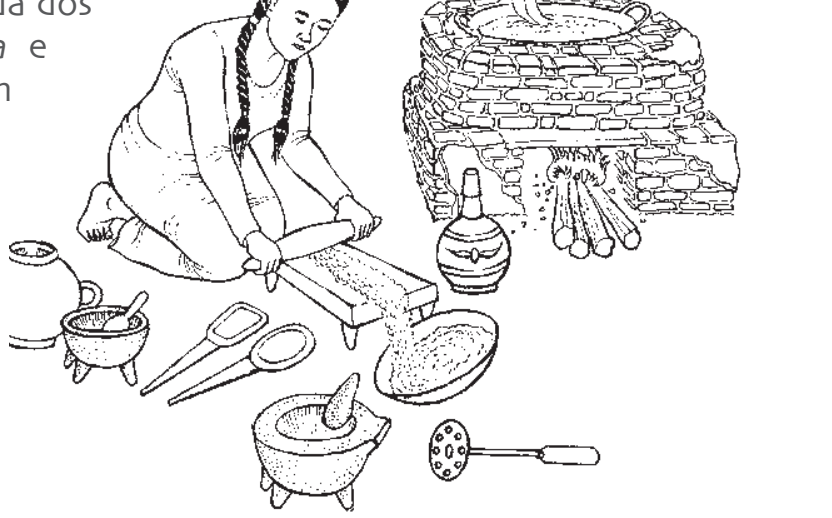

Durante o século XVII, essa pimenta era comercializada mundialmente pelos mercadores holandeses e ingleses. Desde o século XIX, os estados de Veracruz, Chiapas e Tabasco têm sido os principais produtores de pimenta-da-jamaica, acompanhados mais recentemente pelos estados de Oaxaca, Campeche e Puebla. A demanda por bagas secas e óleo essencial continua crescendo. Entre 1990 e 2000, a produção total mexicana de pimenta-da-jamaica aumentou de 868 para 4980 toneladas. A maior parte da producão é exportada para a América do Sul, Estados Unidos, Europa e Oriente Médio e somente 2,2 por cento é consumida no México. No ano de 2000, o valor total exportado foi de 12,87 milhões de dólares. 


\section{O cultivo do sabor mexicano}

A pimenteira, uma árvorequecresce até 20 metros de altura, é nativa* das florestas tropicais do México, Honduras, Guatemala, Belize e Jamaica. Ela já está se tornando escassa nas florestas da região da Sierra Norte de Puebla, leste mexicano, onde a crescente população humana tem causado cada vez mais desmatamento das florestas para a implantação de lavouras e criação de gado. Por outro lado, a crescente demanda internacional por especiarias tem sido um fator catalisador do cultivo de pimenteiras nessa região e arredores, e nas últimas duas décadas o número dessas árvores dobrou.

As pimenteiras podem ser encontradas principalmente nas plantasões de café sombreado de Sierra Norte de Puebla, juntamente com outras valiosas espécies tropicais como mamey, banana, laranja, mandarim, cedro, mogno e grandiúva (que é usada para fabricar papel de casca de árvore - veja o caso do amate neste volume). No município de Tuzamapan, cada hectare de plantação de café tem cerca de 70 a 100 pimenteiras produtivas, que produzem até 120 quilos de frutos verdes. Cada quilograma de pimenta é vendido por aproximadamente 2,20 dólares. Essas pimenteiras são valiosas não somente por razões econômicas, mas também porque ajudam a melhorar o solo através das folhas caídas, que formam uma camada que o protege da erosão nos terrenos montanhosos como os de Sierra Norte de Puebla.

Nas plantações de café, uma prática comum é a poda dos ramos das árvores vizinhas para aumentar a produção das pimenteiras. Além das plantações de café sombreado, as pimenteiras são cultivadas em quintais, milpas* (roças de milho) e potreiros* das pequenas fazendas de gado. Os agricultores também protegem a regeneração natural de pimenteiras nas áreas onde elas não são cultivadas. Quando fazem a limpeza do terreno os agricultores cuidam para não cortar as pequenas mudas de pimenteira. Alguns agricultores usam até cercas ou replantam as mudas dentro dos seus cafezais. Outros, ainda, estabelecem pequenos viveiros de mudas.

\section{Colhendo as fragrantes bagas verdes}

A colheita das bagas de pimenta-da-jamaica é feita pelos homens, nos meses de maio a agosto. É uma tarefa em que não faltam riscos já que os colhedores se equilibram em andaimes montados entre os ramos grandes das plantas. Para cortar os pequenos ramos com frutos, eles se amarram às arvores para não caírem e usam varas para coletarem os frutos dos ramos mais distantes, colhendo até 25 quilos de bagas por dia.

Quando os colhedores retornam para casa, as mulheres e crianças arrancam as bagas verdes dos pequenos ramos. Elas espalham as bagas sobre uma superfície plana de cimento ou sobre lonas 


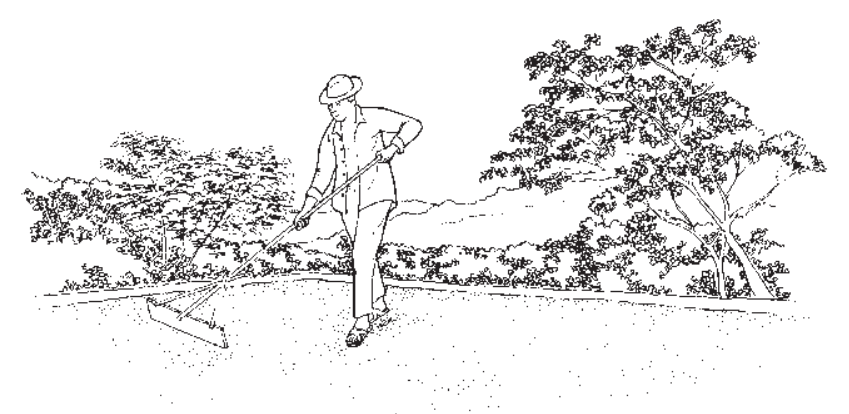

As bagas de pimenta são secas ao sol por até cinco dias. para secá-las ao sol. Um importante estágio no processo de secagem é tornar as bagas "doces" - o que requer um conteúdo exato de umidade na pimenta seca. O primeiro dia no sol garante que a pimenta adquira o seu aroma característico e cor negra, mas leva ainda quatro a cinco dias para os frutos secarem adequadamente. Alternativamente, as bagas podem ser processadas mais rapidamente em um período de somente nove horas, em um secador elétrico. Depois, os produtores usam peneiras para remover as frutas danificadas e classificar as bagas restantes por tamanho.

\section{O mercado de pimenta-da-jamaica}

No comeso dos anos 1970, comerciantes nômades visitavam a região para comprar pimenta e então seguiam para vendê-la nas cidades como Cuetzalan e Veracruz. Mais recentemente, os agricultores têm se organizado em associasões de produtores de pimenta-da-jamaica, assumindo maior responsabilidade tanto sobre a produção quanto as vendas. Com o apoio do Estado, essas pequenas cooperativas começaram a exportar a sua produção através de intermediários.

A colheita e o processamento da pimenta-da-jamaica representa uma importante atividade econômica para muitas famílias na Sierra Norte de Puebla. Em anos recentes, essa atividade foi a salvação de produtores de café, cujos preços caíram muito no mercado internacional. Na verdade, a pimenta-da-jamaica tornou-se uma fonte de renda mais importante que o próprio café. Para se ter uma idéia, em Tuzamapan, na Sierra Norte de Puebla, onde cerca de 56 por cento dos habitantes estão engajados na produção de pimenta-da-jamaica, 17 por cento da sua renda total vem dessa pimenta enquanto o café representa somente 11 por cento.

Embora os presos internacionais dos dois produtos sejam sujeitos à instabilidade e flutuasões de mercado, ambos continuam importantes para o sustento de muitos agricultores. A diversidade de cultivos dá certa proteção contra incertezas econômicas ou mudanças que podem afetar um deles em particular, como sofreu o café. Os agricultores locais se beneficiam muito das árvores de pimenta, que Ihes dão uma fonte direta de renda, bem como tempero para uso diário, folhas medicinais e sombra para as plantas de café. Os plantios consorciados* de café também trazem outros benefícios aos agricultores, fornecendo-lhes recursos valiosos como frutas, lenha, plantas medicinais e ervas.

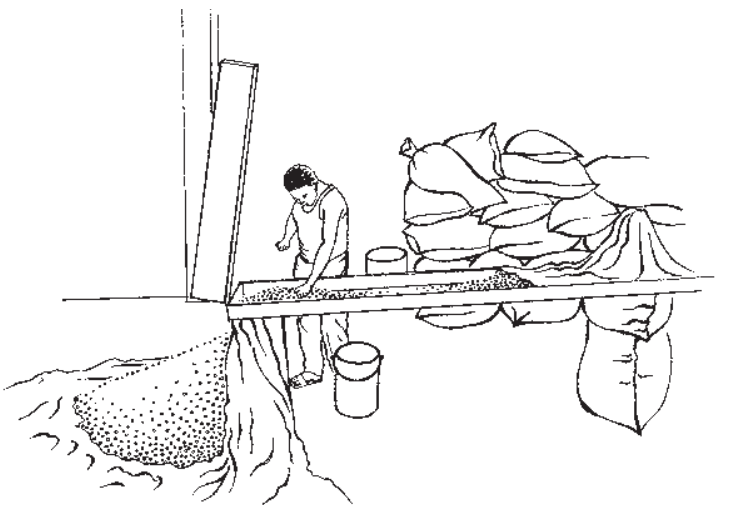

Peneiras são usadas no processo de classificaşão, ajudando a eliminar as bagas danificadas e a separar as restantes por tamanho.

\section{0}




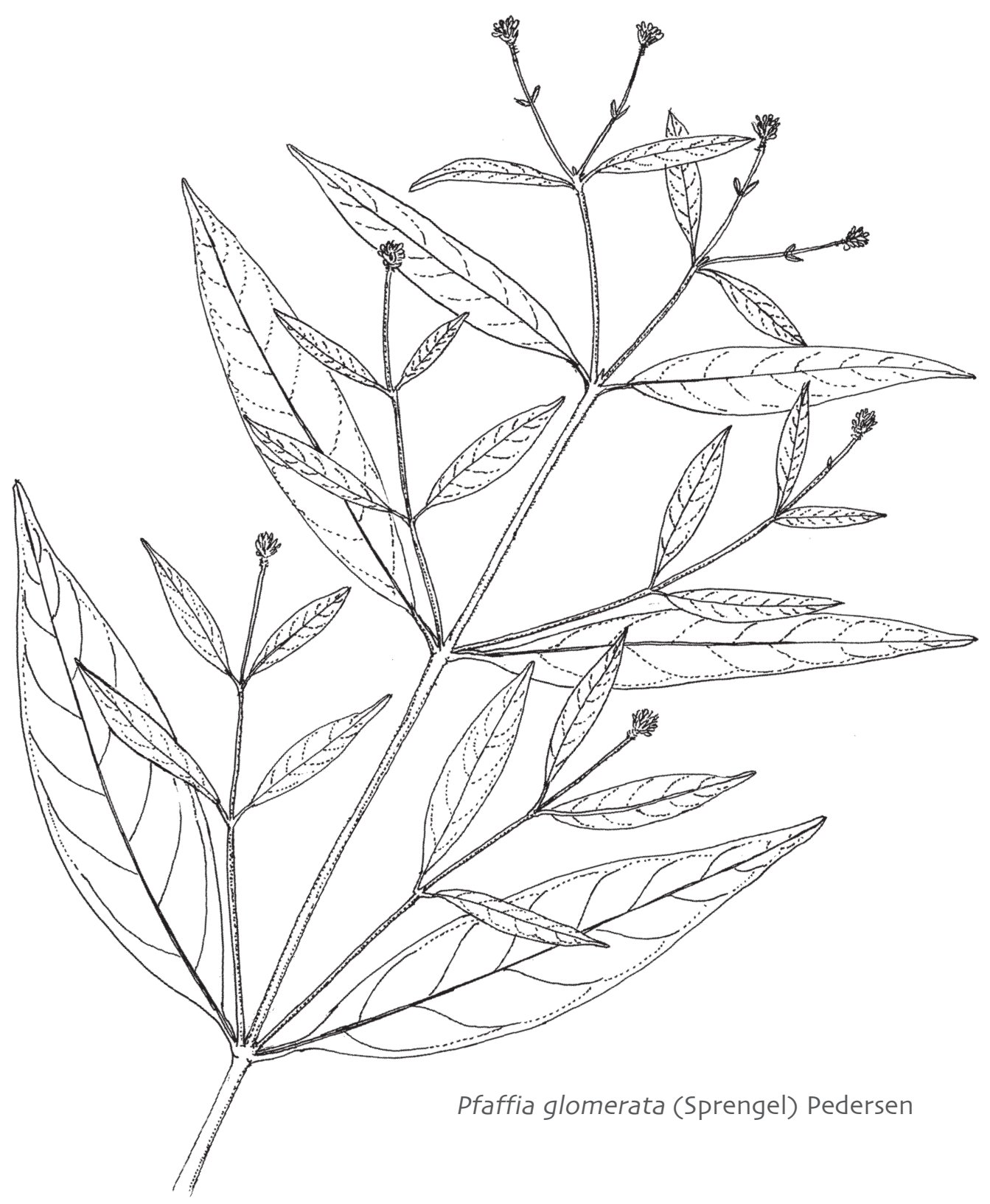

\section{Fáfia, ginseng brasileiro}

Caso brasileiro apresentado por Cirino Corrêa Júnior e Lin Chau Ming 


\section{Fáfia: A raiz que cura todos os males}

Pode existir uma planta medicinal que cure qualquer doença? Isso parece ser bom demais para ser verdade, mas muitos agricultores e habitantes das florestas no Brasil consideram que a fáfia (Pfaffia glomerata) é uma dessas plantas. Durante séculos, a erva conhecida como 'para-tudo tem', de fato, curado pessoas doentes e tratado enfermidades desde o diabetes até diarréia e hemorróidas.

Ansiosos por testar esse incrível fato do conhecimento local, pesquisadores mostraram que os extratos dessa planta têm propriedades analgésicas (capacidade de aliviar dores) e promovem a regeneraşão celular e purificasão do sangue. Podem também ser usados no tratamento de doenças da pele e tumores. Entretanto, a recente explosão da exploração da fáfia se deve mais à sua efetividade como tônico do que à sua capacidade de curar doenças. Os tônicos são amplamente usados no Japão, que geralmente têm o ginseng como principal componente. Tanto o ginseng (Panax ginseng e P. quinquefolim) como a fáfia são

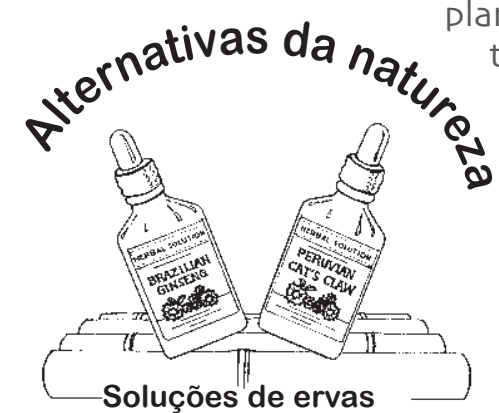

Hoje, você pode comprar produtos medicinais de fáfia via internet.

lantas herbáceas* e seus extratos medicinais são obtidos a partir de suas raízes

tuberosas*. As raízes de ambas as plantas têm aparência similar e como os extratos de fáfia têm efeitos similares aos do ginseng, grandes quantidades dela são agora exportadas para o Japão.

Embora ela não seja botanicamente relacionada como ginseng, osconsumidores japoneses associam as potentes propriedades da fáfia com o famoso remédio que Ihes é familiar, particularmente porque seu nome comercial é ginseng brasileiro. Na verdade, a fáfia se converteu em um substituto botânico, parte do grande mercado para os análogos* ao ginseng: além do brasileiro, existem também o coreano, o americano, o peruano e o da Malásia. Algumas dessas plantas estão relacionadas com a espécie original proveniente da Ásia enquanto outras levam o nome por razões puramente comerciais, tirando vantagem da reconhecida reputação medicinal do gingseng.

\section{As populaşões locais e a base de recursos}

A fáfia, também conhecida como batata-do-mato nos países de língua inglesa, é um arbusto nativo* do Brasil. Essa planta silvestre* cresce muito bem em solos úmidos, sob luz direta do sol e tolera até inundações periódicas. No planalto sul do Brasil, cresce nas várzeas e nas florestas de galeria*, ao longo das margens dos rios, onde pode receber grande quantidade de radiação solar.

A área de distribuição geográfica da fáfia é muito pequena, e está quase toda dentro do Parque Nacional da Ilha Grande, no Paraná. Os solos dessa região são arenosos e pobres, de baixa produtividade agrícola. Para os pequenos agricultores da região não é fácil ganhar a vida cultivando a terra e a coleta da fáfia tornou-se uma oportuna alternativa de renda, apesar da coleta dentro de uma área de preservação ser ilegal.

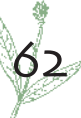




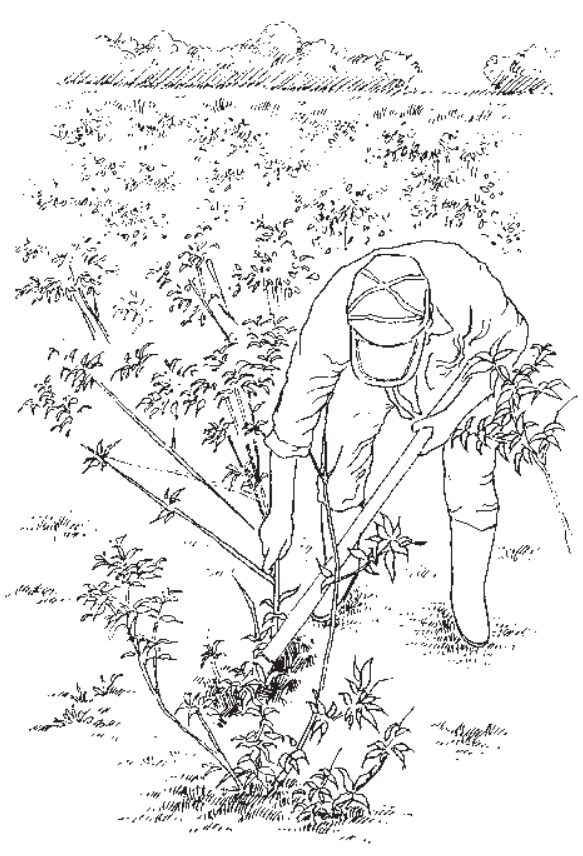

A colheita da fáfia é demorada porque as raízes têm que ser arrancadas manualmente.

\section{A extração da fáfia}

Os índios brasileiros e as populações locais utilizaram a raiz da fáfia por muitas gerações, mas a sua exploração comercial começou somente por volta de 1990. As raízes são arrancadas com uma enxada ou pá e em um dia de trabalho um coletador pode render até 84 quilos de raízes frescas. As plantas crescem agrupadas e as raízes extraídas de plantas individuais chegam a pesar entre 250 gramas e 1,5 quilos. A época de colheita da fáfia é bastante curta, de maio a julho, período em que as áreas em que cresce não estão inundadas. Para sorte dos agricultores, esse é o período de entressafra das lavouras, e eles podem dedicar todo o seu tempo à coleta das raízes.

Não é fácil encontrar as plantas de fáfia no meio da vegetação natural da várzea. Mas os agricultores sabem que ela é uma das primeiras plantas a rebrotarem após uma queimada, e usam o fogo como estratégia para facilitar a localização das plantas. O fogo é também uma prática de manejo usada para evitar o crescimento desordenado da vegetação e para eliminar animais peçonhentos. O uso do fogo é parte do repertório de conhecimento tradicional dos agricultores em muitas regiões do Brasil. Entretanto, quando usado sem controle pode causar grande dano ao meio ambiente, por isso é atualmente proibido como prática de manejo da terra pela legislação ambiental brasileira.

Os locais preferidos para a coleta da fáfia são as ilhas do rio Paraná, onde estão as raízes mais pesadas e consideradas de melhor qualidade, provavelmente devido aos solos mais ricos e úmidos que ali se encontram. Os coletores transportam as raízes até as suas casas com cavalos, bicicletas, carrosas ou barcos. Em pouco menos de uma década, a fáfia tornou-se uma planta muito importante não somente para os japoneses, europeus e americanos que a consomem, mas também para as famílias rurais do planalto sul do Brasil que a coletam.

\section{O processamento e a comercialização}

Os coletores vendem as raízes brutas para compradores locais a presos que variam de 0,20 a 26 centavos de real $(0,10$ a 0,13 dólares) por quilo, o que resulta para eles uma renda anual de cerca de 4400 reais (2 200 dólares) por família. Os compradores lavam, picam e trituram as raízes até obter uma pasta, que é então seca ao sol sobre lonas plásticas. Os intermediários compram a pasta, moem-na até que fique na forma de pó, e em seguida a esterilizam e embalam para exportacão. Os exportadores pagam em torno de 30 reais (15 dólares) por quilo, praticamente 150 vezes o preso das raízes frescas.

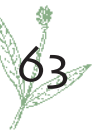




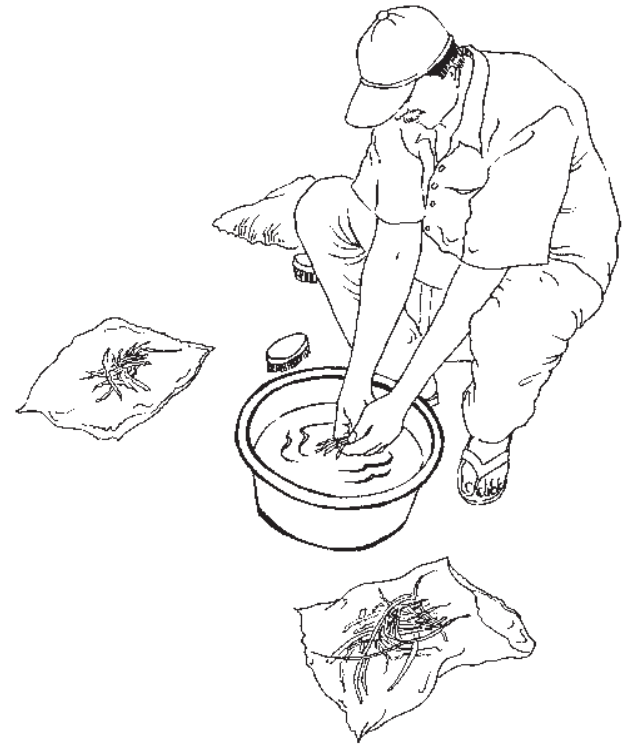

Os compradores locais lavam bem as raízes de fáfia antes de picá-las e amassá-las até formar uma pasta.

\section{Domesticação: Uma alternativa em que todos ganham?}

O ginseng brasileiro representa um fascinante exemplo de substituição global. Neste caso, o nome comum de outra planta (gingseng) foi utilizado para promover a comercialização da fáfia, que sequer tem qualquer parentesco botânico com o seu homônimo de renome internacional. Por séculos, da China às Américas, o nome 'ginseng' tem sido associado a um tônico saudável elaborado a partir de raízes com grandes propriedades regeneradoras. O truque do uso do nome funcionou: a demanda por raízes de fáfia, principalmente no mercado internacional, aumentou 10 por cento ao ano durante a última década. Por outro lado, esse crescimento implicou uma drástica redução das populaš̃es naturais da planta. Se nenhuma medida for logo implementada, apesar dos esforsos dos guarda-parques para controlar a colheita ilegal, é muito provável que nos próximos anos vamos testemunhar o desaparecimento da fáfia das áreas do Parque Nacional da Ilha Grande.

Para evitar que sejam surpreendidos pelos guarda-parques, os coletores ilegais exploram as áreas não fiscalizadas do parque ou fazem a coleta das raízes na escuridão da noite. A sua habilidade em driblar as medidas de controle e a falta de efetividade da legislação têm levado à degradação desse recurso. Em resposta a superexploração, pesquisadores e agricultores juntaram forças para cultivar e domesticar* a espécie, e tornar a fáfia uma cultura comercial potencialmente viável.

A domesticação da fáfia permite que os agricultores a cultivem em suas próprias terras, ao invés de dependerem da coleta de populacões silvestres. Eles produzem as próprias plântulas* através do uso de sementes ou estacas* de ramos. Os agricultores selecionam as plantas mais vigorosas para coletarem as sementes ou obterem as estacas, uma estratégia para aumentar o rendimento da cultura. As pesquisas têm mostrado um potencial de produtividade de duas toneladas de raízes secas por hectare por ano, para uma densidade de 20000 plantas por hectare.

Antes de colher as raízes, os agricultores extraem as sementes ou cortam as estacas para a próxima estação de crescimento. A produção da própria semente dessa maneira dá aos agricultores independência para continuarem o cultivo da fáfia, garantindo a oferta constante de produto e dos benefícios econômicos da sua coleta e comercialização. O recente êxito do cultivo da fáfia traz a esperança de que mais agricultores possam um dia colher raízes à luz do dia, sem ter que espreitar constantemente à sua volta à procura dos guarda-parques. 

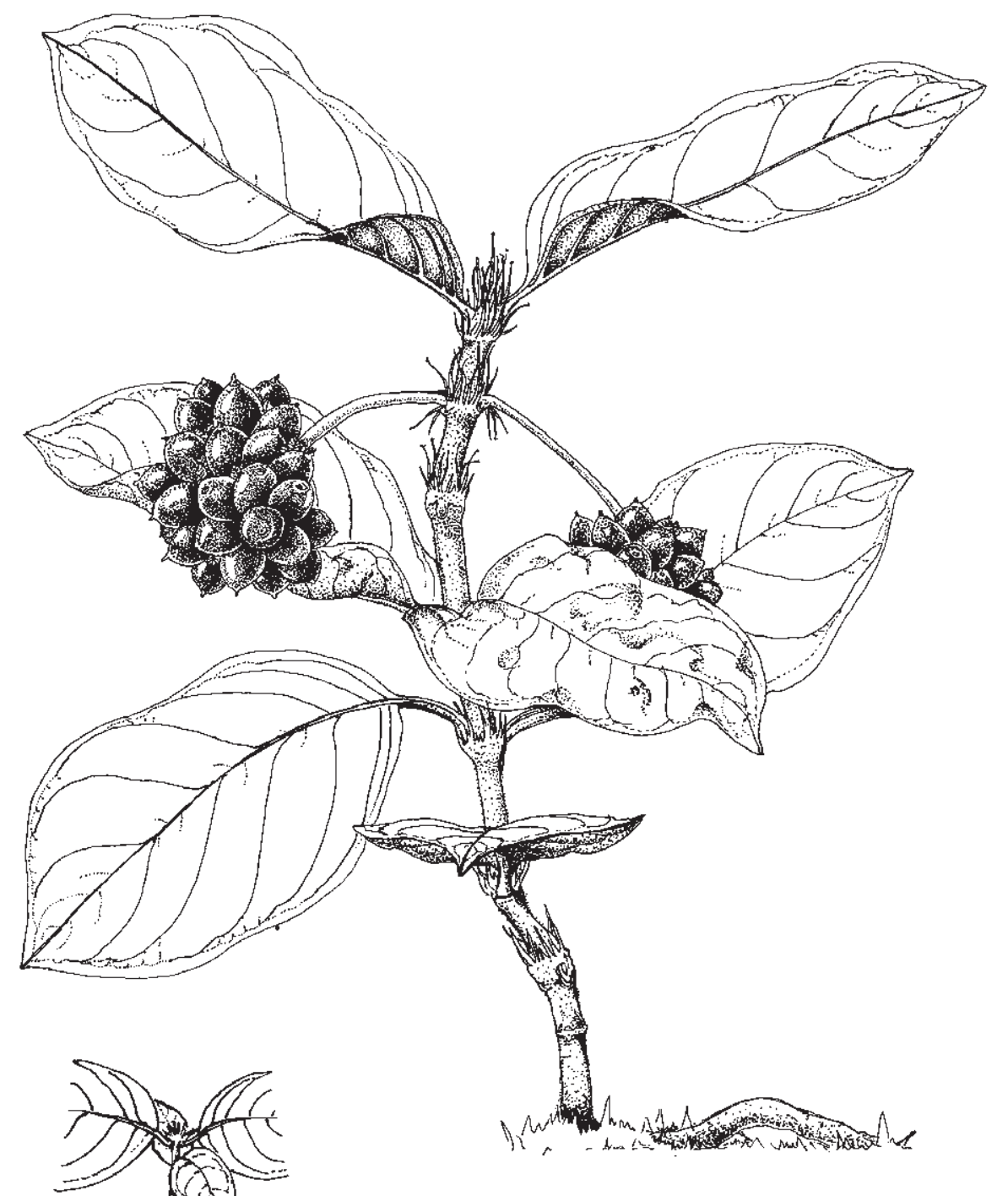

Psychotria ipecacuanha (Brot.) Stokes

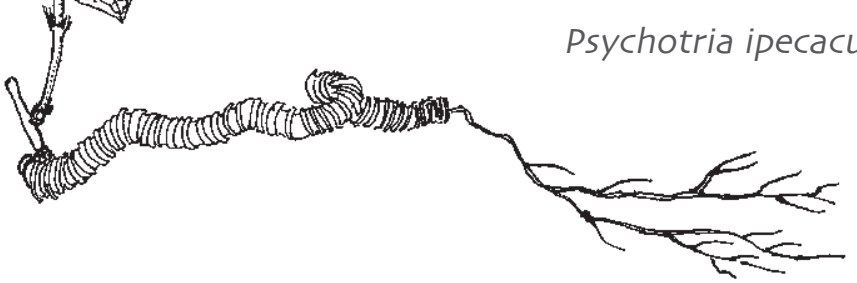

\section{Ipeca, raiz medicinal}

Caso costarriquenho apresentado por Rafael A. Ocampo Sánchez 


\section{Ipeca: Um remédio das florestas da Costa Rica}

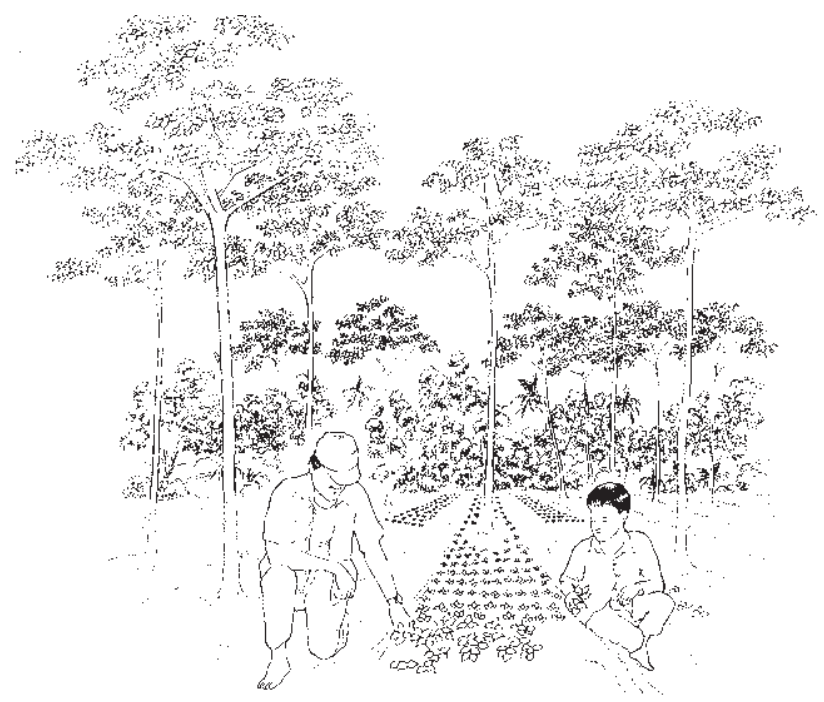

As mudas de ipeca são plantadas na sombra das árvores da floresta

O radiante governo de Luís XIV, mais conhecido como - Rei Sol da França, teria acabado bem mais cedo se não fosse por uma pequena planta das florestas úmidas do outro lado do mundo. Conta a história que a ipecacuana (Psychotria ipecacuanha), chamada em português de ipecacuanha ou simplesmente ipeca, uma planta nativa da América do Sul e Central, curou de uma disenteria o dito monarca no século XVIII. Desde a década de 1760 , essa raiz tem sido utilizada na Europa como amebicida (para matar parasitas intestinais), expectorante (para eliminar a congestão do trato respiratório) e como um poderoso emético (para induzir o vômito). Mas não há dúvida que os índios Guarani da América Central já tinham familiaridade com os poderes curativos dessa planta muito antes.

A indústria farmacêutica internacional comeşou a comercializar a raiz de ipeca no comeso do século XX, quando reconheceu os benefícios da sua aplicação medicinal. O nome moderno da planta ipecacuana provém da palavra indígena 'ipe-kaaguene', que significa 'planta que adoece à beira do caminho' apesar de ser conhecida na Costa Rica como raicilla (raizinha). Seus ingredientes ativos - os alcalóides* cefalina, emetina e sicotrina - são extraídos das raízes da planta. Na década de 1940, principalmente durante a Segunda Guerra Mundial, a ipeca era uma das plantas mais utilizadas na indústria farmacêutica dos Estados Unidos e Europa. Ainda hoje continua sendo usada no tratamento de parasitoses, tosse, bronquite e em geral como remédio homeopático*. Em muitas partes do mundo, muitas mães guardam no armário de remédios um pouco dessa raiz para fazer as crianças vomitarem quando elas comem ou engolem algo que não deveriam! Recentemente, também está sendo estudado o potencial da ipeca no tratamento do câncer.

\section{Tecnologia rudimentar, alta qualidade}

A ipeca é encontrada nas florestas desde a Nicarágua até a Costa Rica, na América Central, e do Panamá até o Brasil, na América do Sul. A planta pode atingir 20 a 30 centímetros de altura, apresenta pequenas flores brancas e produz abundantes sementes, que são dispersas por pássaros. A espécie cresce na sombra das grandes árvores da floresta e não tolera a luz direta do sol. 
As raízes de ipeca eram originalmente colhidas de populações silvestres* da espécie na América do Sul e Central, o que na verdade ainda ocorre no Brasil. Mas em países como a Costa Rica e a Nicarágua, a crescente demanda pelo produto estimulou o seu cultivo em plantasões dentro das florestas, onde o dossel* protege as plantas da luz direta do sol. Na Costa Rica, cerca de 35,5 hectares de floresta são utilizados para o cultivo de ipeca, produzindo raízes com boas concentrasões de alcalóides, principalmente quando as plantas estão floridas. Reconhecida pelas suas qualidades medicinais, a ipeca também foi introduzida na Índia, onde é produzida em grandes plantacões em sistema de monocultivo*. Entretanto, a qualidade dos extratos de alcalóides é baixa se comparados aos obtidos na Costa Rica, embora os avansos tecnológicos permitam contornar esse problema.

\section{O cultivo aumenta a oferta}

A diminuição dos estoques naturais obrigou empresários e agricultores a explorarem alternativas para sustentar a oferta dessa valiosa espécie medicinal. Na Nicarágua, o cultivo da ipeca nas florestas comesou na década de 1850 e se estendeu à região vizinha de Huetar Norte, na Costa Rica. Ali, os empresários usaram a habilidade e o conhecimento dos indígenas malekus para adaptar as práticas do seu cultivo em condições de floresta.

Em Huetar Norte, aproximadamente 48 famílias cultivam a ipeca, mas um grande número de imigrantes nicaragüenses que chegou à região nos últimos anos também passou a produzir a raiz. Um hectare cultivado com ipeca pode produzir cerca de 2,8 toneladas de raiz seca, que atingem um valor de mercado próximo a 5,4 bilhões de colones costarriquenhos (17 ooo dólares). Mas, somente cinco por cento dos agricultores se dedicam exclusivamente ao seu cultivo. A maioria deles cultiva uma diversa gama de espécies nativas*, incluindo o milho, feijão, mandioca e tiquisque* (uma espécie de inhame).

Um conhecimento ecológico sutil ajuda os agricultores a determinarem quais as árvores da floresta que devem ser eliminadas e quais as que devem ser mantidas quando preparam o terreno para o plantio das mudas de raicilla: as gotas de chuva que caem de folhas com diferentes formatos e tamanhos têm diferentes efeitos. Das árvores que têm folhas pequenas saem pequenas gotas, que não causam danos às plantas de ipeca que crescem abaixo delas e por isso são mantidas na floresta. Depois do plantio, a cada quatro a seis meses se eliminam as espécies que competem com a ipeca. As raízes são colhidas três a quatro anos após o plantio, geralmente na época das chuvas, quando a alta umidade do solo torna mais fácil o trabalho de arrancá-las, resultando também em menor número de raízes quebradas. A área colhida é então deixada descansar por cinco a seis anos antes que seja novamente plantada. 
Depois da colheita, as mulheres e as crianças secam as raízes ao sol, em local próximo às suas casas. Depois, as raízes são ensacadas e transportadas para uma das duas empresas privadas que se encarregam da sua exportação. Antes de serem mandadas para o exterior, ainda são picada em pequenos pedacos e embaladas. O restante do processamento ocorre nos países importadores, como Estados Unidos, México, Alemanha, França, Tailândia e Malásia.

\section{Um mercado muito volátil}

Nicarágua, Brasil, Costa Rica e Índia são os principais produtores de raízes de ipeca. A Nicarágua supre 32 por cento da demanda mundial e a Costa Rica, outros 20 por cento. No início da década de 1980, o governo da Costa Rica incentivou os agricultores a estabelecerem plantacões de ipeca como parte de um programa voltado para cultivos não tradicionais. Uma cooperativa foi formada 10 anos depois para tentar estabilizar os presos e padronizar as vendas através da centralização da compra de raízes, mas ela entrou em colapso poucos anos depois. A iniciativa privada

Flutuação dos preşos de exportação de ipeca

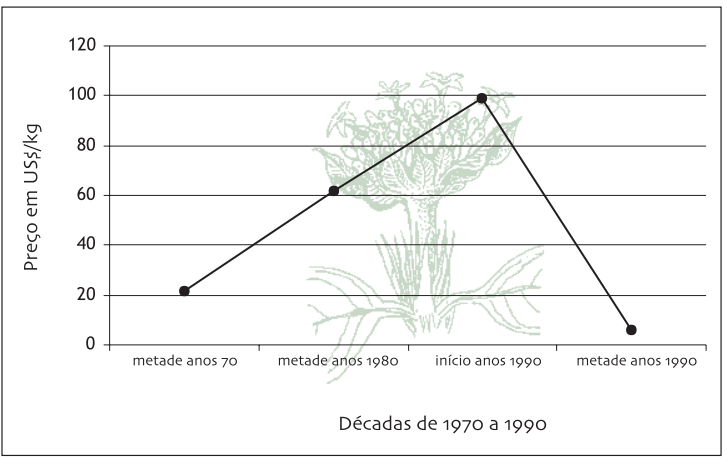

contribuiu em parte para esse fracasso, pelo abuso dos subsídios governamentais e ao superestimar o volume exportado.

As flutuasões do preşo e da comercialização têm sido desastrosos para a produção de raízes de ipeca, assim como para o meio de vida das famílias envolvidas nessa atividade. $O$ excesso de produção e a estagnação do mercado internacional causaram queda nos presos da raiz. Além disso, a especulação e abuso do programa nacional de subsídios, juntamente com as expectativas iniciais pouco realistas de altas receitas geradas pela exportação também contribuíram para o declínio. Apesar de tudo, atualmente se vive um renovado interesse pelo produto.

A produção de ipeca tem flutuado tanto quanto os presos mundiais. Entre 1961 e 1985, quando a producão era estável, a Costa Rica exportou uma média de 20 toneladas de raízes por ano. Esse volume atingiu as 100 toneladas em 1989, antes de despencar para 65 toneladas em meados de 1990. O volume exportado atingiu novamente as 100 toneladas em 1996, para sofrer uma nova queda para menos de 30 toneladas no ano de 2000.

Os produtores enfrentam uma série de problemas: baixos presos, estagnação do mercado, falta de apoio governamental, competição de outros países produtores como a Índia, e substitutos sintéticos. Outro problema é o desmatamento. O aumento na conversão da floresta para agricultura e criação de gado significa cada vez menos fragmentos de floresta primária* onde a raiz medicinal pode ser cultivada. Os agricultores têm conseguido superar essa limitaşão plantando ipeca em florestas secundárias", ou na sombra das plantasões de cacau. Até agora, a estratégia tem dado certo e eles têm conseguido manter um alto conteúdo de alcalóides nas raízes que produzem, o que lhes garante uma vantagem comparativa no mercado ao oferecerem um produto de alta qualidade. 


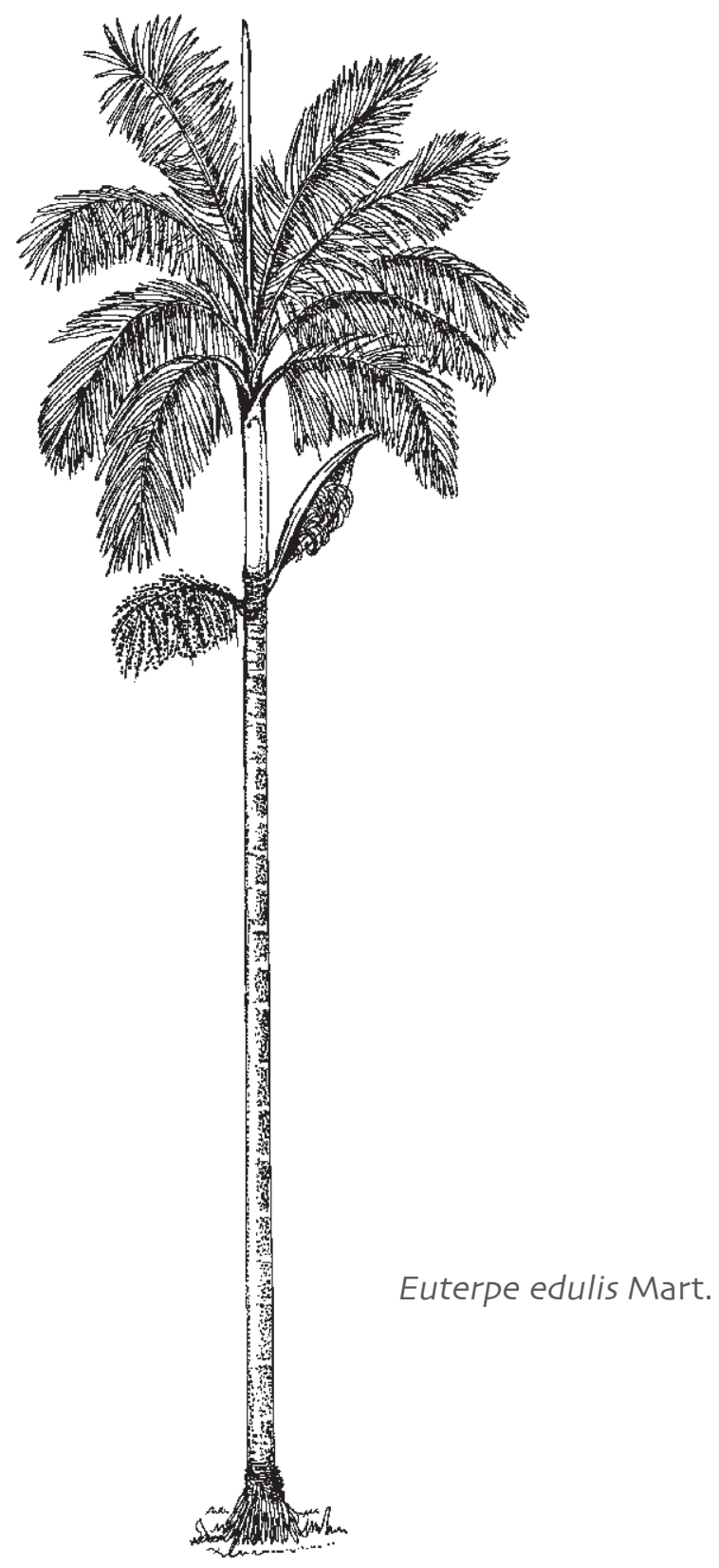

\section{Palmito}

Caso brasileiro apresentado por Alfredo Celso Fantinii 


\section{Palmito: Um sofisticado alimento das florestas}

O palmito é um produto da floresta muito especial, apreciado pelos povos indígenas* desde muito antes da chegada dos europeus à América. Hoje, é um dos produtos florestais mais conhecidos no Brasil. Consumido principalmente na forma de conserva, levemente salgada e ácida, o palmito é um excelente acompanhamento para qualquer prato. Embora alguns chefes de cozinha de restaurantes famosos insistam em cobrir o palmito com molhos sofisticados,
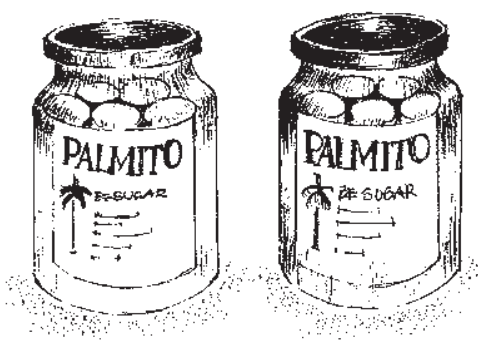

O palmito é um delicioso acompanhamento para qualquer prato. um verdadeiro gourmet não aceita mascarar o seu sabor natural.

Até recentemente, no sul do Brasil, o palmito era um item indispensável em festas importantes. Mais que isso, a abundância e o diâmetro dos palmitos servidos aos convidados era uma medida da significância e do sucesso do evento. Plantas inteiras de palmiteiro também serviam como elegante decoração das casas e ruas durante as festividades, uma tradição que praticamente desapareceu. Troncos e folhas desta palmeira também eram muito utilizados em construsões rústicas na zona rural. Entretanto, a urbanização da região da Mata Atlântica tornou disponíveis novos materiais de construsão que substituíram o palmiteiro.

\section{Uma palmeira abundante em florestas virgens}

Até 50 anos atrás, a palmeira Euterpe edulis ocorria naturalmente em toda a Mata Atlântica brasileira, em densidades de cerca de 350 plantas por hectare. Entretanto, o desmatamento na região e a superexploração dizimaram a espécie. O rápido declínio das populašões naturais do palmiteiro afetou não somente a ecologia das plantas da região, mas também a de muitas espécies de animais - incluindo grandes pássaros, mamíferos e roedores - que sempre dependeram da sua produção abundante de frutos como fonte de alimento durante vários meses do ano.

A "cabeça do palmito" é a parte verde apical ou a ponta do tronco do palmiteiro, formado pelas bainhas das folhas jovens da planta. As bainha mais internas, que são as mais jovens e tenras, representam o que chamamos de palmito ou o "coração da palmeira". A colheita do palmito geralmente ocorre quando a planta tem cerca de 8 a 10 anos, e infelizmente a planta tem que ser morta no processo de retirada desse delicioso produto. Um palmiteiro adulto pode atingir uma altura de 15 metros, mas somente uma pequena parte dele forma o palmito comestível. Um palmiteiro inteiro produz somente uma ou dois vidros de 300 gramas de

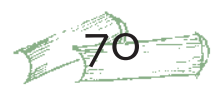


palmito. Praticamente todo o palmito produzido na região da Mata Atlântica é extraído da floresta e infelizmente o seu manejo sustentável da espécie é muito pouco comum.

\section{Produção legal e clandestina de palmito}

A produção de palmito contribui significativamente para a renda de muitas famílias da zona rural da Mata Atlântica. Uma das vantagens desse produto é que o corte do palmito pode ser feito em qualquer época do ano, e por isso o estoque de palmiteiros na floresta é considerado uma verdadeira 'poupança verde'. Até recentemente, quando os
agricultores necessitavam de algum dinheiro para uma emergência eles
iam até a floresta e cortavam um feixe de palmitos e o vendiam.

A industrialização (processamento e envasamento) em larga escala do palmito teve início da década de 1960, quando as fábricas passaram a ser as principais compradoras de palmito in natura. Hoje em dia, o palmito em conserva pode ser encontrado em qualquer supermercado. Outros importantes compradores são os restaurantes, especialmente as churrascarias, que servem grandes pedaços de palmito como atrativo.

No Brasil, a produção de palmito é regulada pelas agências ambientais federais e estaduais. A extração do palmito só é permitida em propriedades privadas, depois que o agricultor tiver o seu plano de manejo do palmiteiro aprovado por essas agências.

A aprovacão de um projeto, entretanto, pode demorar meses e custar caro para o agricultor. Esses obstáculos burocráticos e financeiros estimulam o agricultor a produzir palmito de maneira clandestina.

\section{Outras espécies entram em cena}

As populações naturais de Euterpe edulis, antes a principal fonte original de palmito, sofreram forte declínio durante décadas, devido à superexploração a que foram submetidas. Atualmente, uma grande fatia do mercado é capturada palmiteiro adulto é suficiente para encher somente um ou dois vidros de 300 gramas cada.

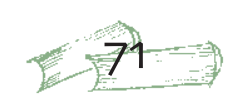


por palmito produzido a partir de espécies aparentadas como Euterpe oleracea e Euterpe precatoria, colhidos de florestas naturais da região amazônica. Mais recentemente, a pupunha (Bactris gasipaes) e as exóticas palmeiras reais (Archontophoenix cunninghamiana e A. alexandrae) começaram a ser cultivadas no Sudeste e Sul do Brasil, para suprir outra parte da demanda por palmitos. Essas espécies podem ser cultivadas em campo aberto uma vantagem sobre Euterpe edulis, que requer um ambiente sombreado durante a fase juvenil. A luz direta do sol também promove um crescimento mais rápido à pupunha e à palmeira real, outra grande vantagem destas palmeiras em relação ao palmiteiro. Mas a alta qualidade do palmito de Euterpe edulis tem motivado os agricultores a cultivarem esta espécie à sombra de culturas de porte alto como a bananeira. Entretanto, incentivos de agências governamentais serão necessários para esta prática tornar-se comum.

\section{De cortadores de palmito a produtores de polpa}

Outro produto obtido de certas palmeiras é o açaí, um suco grosso de cor púrpura extraído dos seus frutos. Na Amazônia, onde o açaí é muito popular, a polpa é extraída de Euterpe oleracea e Euterpe precatoria. Na Mata Atlântica, um açaí de mesma qualidade pode ser produzido dos frutos de Euterpe edulis - e embora esta prática ainda não seja comum, a demanda pela produto cresce rapidamente. A coleta de frutos para produzir o açaí não mata a palmeira - a maior vantagem da produção de polpa ao invés de palmito. Cada palmeira pode então gerar uma renda anual para os agricultores, ao contrário da única renda que cada palmeira dá quando é cortada para produzir o palmito. Além disso, depois de extraída a polpa, as sementes podem ser usadas para enriquecer a floresta com novas palmeiras.

O sistema viário do sul do Brasil é muito melhor que o da Amazônia, o que permite aos agricultores se envolverem mais facilmente na produção e comercialização do açaí. A crescente demanda e as oportunidades de mercado para esse produto estão estimulando muitos agricultores na região da Mata Atlântica a manterem os seus palmitais de pé, trazendo uma renovada esperança tanto para eles quanto para a conservação da espécie.
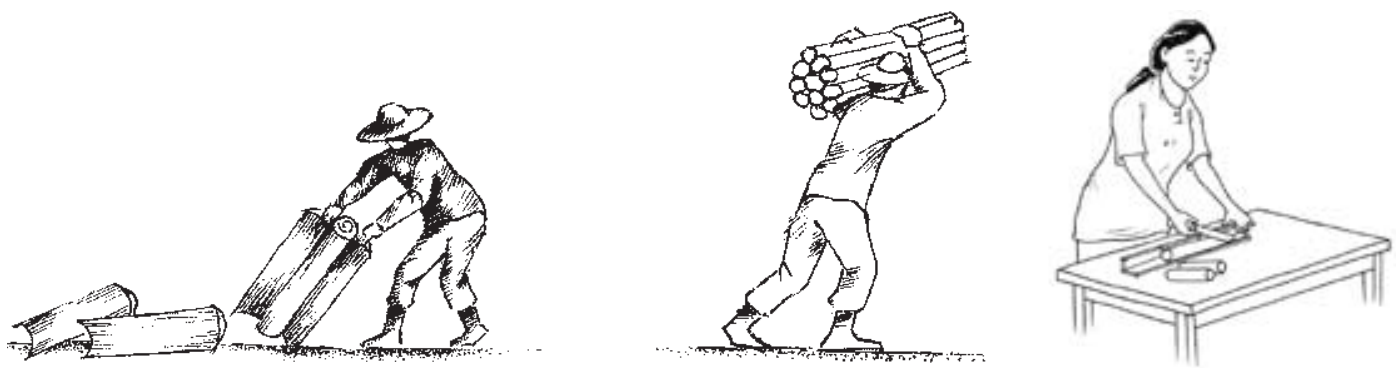

Durante o processamento industrial, as bainhas das folhas restantes são removidas para se chegar ao palmito, que é cortado em pedaços de 8 centímetros de comprimento, e cozido dentro dos vidros.

bainhas mais externas, deixando somente algumas para proteger o palmito macio.

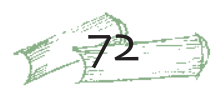



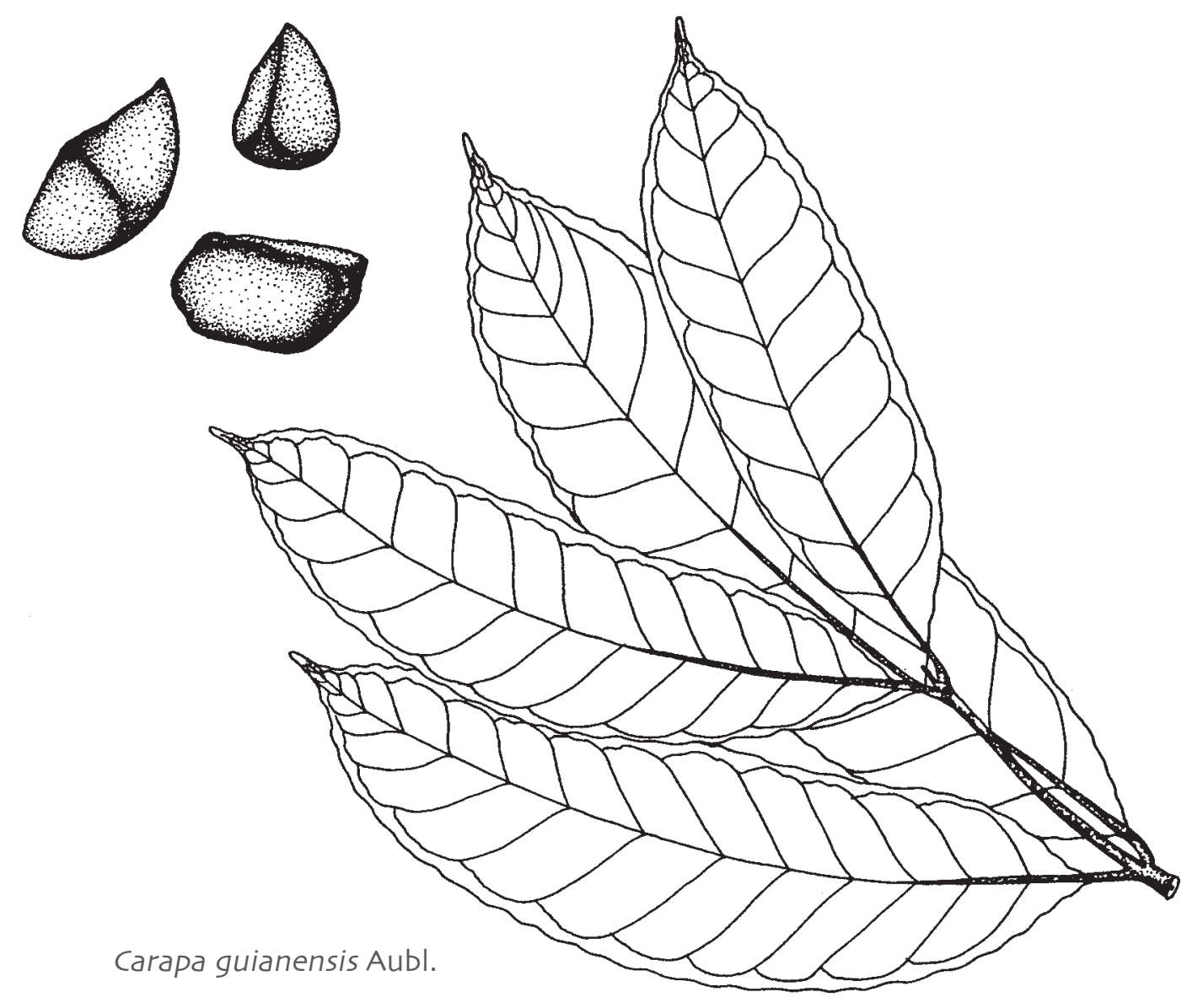

Carapa guianensis Aubl.

\section{Andiroba, óleo medicinal}

Caso brasileiro apresentado por Patricia Shanley 


\section{Andiroba: Um bálsamo para curar machucados, e nos livrar de insetos e da dengue}

Você está vendo o seu tornozelo torcido inchar e ficar roxo? Está aflito tentando matar os mosquitos da dengue, com medo de pegar a doença? Vai com freqüência ao banheiro com dor de estômago causada por parasitos? Está levando o seu bicho de estimasaão ao veterinário para tratar um ferimento infeccionado? Ou, quem sabe, você está procurando mesmo é um móvel bonito e durável? Se a resposta para qualquer dessas perguntas é 'sim', o que você deve procurar é a casca, o óleo ou a madeira da andiroba.

Conhecida como crabwood na Guiana e caoba bastarda na América Central devido à sua linda e resistente madeira de cor vermelha, a andiroba (Carapa guianensis) é uma árvore de tamanho médio e que apresenta sapopema (engrossamento do tronco próximo à base). Seu tronco reto pode atingir 30 metros e a espessa casca se desprende em grandes pedaços. Da casca pode-se preparar um chá amargo que, dizem

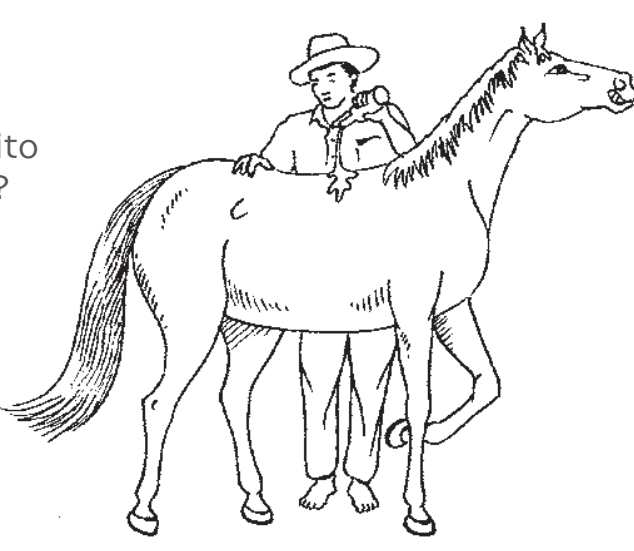

Além de ser amplamente usado pelos humanos, o óleo de andiroba também beneficia os animais domésticos ajudandoos a curar ferimentos e irritação da pele. os habitantes da Amazônia, é efetivo no combate aos vermes e à febre e é poderoso no tratamento de tumores. Também da casca se faz um pó que é usado para tratar vários problemas da pele. Além da sua casca e da excelente qualidade da madeira, a andiroba é principalmente procurada pelo óleo pegajoso que pode ser produzido das suas sementes. Usado por todos, do agricultor ao executivo da cidade, o óleo de andiroba é encontrado mais facilmente do que a aspirina no armário de remédios de muitas casas da Amazônia.

\section{Do nascimento à velhice: enfermidades do bebê, insetos e artrite}

Por séculos, os grupos indígenas* brasileiros tradicionalmente têm pintado a sua pele com uma mistura do aromático óleo de andiroba e do pigmento vermelho brilhante extraído das sementes de urucum (Bixa orellana). Ao mesmo tempo em que proporciona um cosmético decorativo, a mistura mantém os insetos bem longe. Esses práticos costumes da cultura indígena estão sendo redescobertos pela indústria internacional de cosméticos que, por exemplo, passaram a usar o urucum na produção de batons. Recentemente, as companhias brasileiras também já descobriram que as velas que têm cascas das sementes de andiroba na sua composição funcionam como repelentes de insetos, e podem manter afastado o mosquito transmissor da dengue (Aedes aegypti).

Nas áreas rurais, o óleo de andiroba tradicionalmente tem sido usado para fabricar sabão, um costume que agora foi incorporado pela indústria que abastece supermercados e farmácias com 
uma ampla diversidade de produtos de higiene pessoal, como cremes, xampus, e bálsamos. O óleo puro também pode ser encontrado nessas casas comerciais.

O óleo de andiroba é usado pelo amazonense desde o seu nascimento, quando é aplicado para cicatrizar o cordão umbilical, até a velhice, quando ele recorre ao óleo para combater doenças como a artrite. Para se ter uma idéia da sua popularidade, somente na cidade de Belém as vendas do óleo de andiroba e de copaíba combinadas atingiram 10 ooo litros no ano de 1994 e o triplo disso em 2002.

\section{Colhedores de remédio florestal}

A andiroba ocorre na Amazônia, América Central e África, preferencialmente nas margens de lagos e rios, mas também pode ser encontrada na floresta de terra firme. A abundância da espécie varia enormemente de região para região, podendo ser encontradas desde uma até oito árvores por hectare. A produção de frutos também é muito variável entre as árvores e de um ano para o outro. Os habitantes da região dizem que uma árvore "descansa" e não produz um fruto sequer em um ano, mas no ano seguinte pode produzir de 50 a 200 quilos de sementes.

Mulheres, homens e crianças, todos se juntam na tarefa de colher as sementes de andiroba nas florestas e várzeas assim que elas caem no chão. Nas praias ao longo do estuário* onde as águas do Amazonas encontram o oceano Atlântico, coletores à pé, de canoa, bicicleta e mesmo em carretas puxada por búfalos vasculham os rios, as praias e as florestas. Conhecendo como ninguém os locais onde os rios e as marés depositam as sementes, os coletores têm olhos treinados para encontrar as sementes entre os detritos e as conchas. Depois da coleta, alguns coletores vendem as sementes diretamente para os comerciantes que as despacham para processamento na vizinha cidade de Belém ou para outras tão distantes quanto São Paulo.

\section{O processamento doméstico na zona rural: o segredo do poder medicinal da andiroba?}

A extração tradicional do óleo é um processo elaborado e lento que varia entre locais e entre as pessoas que o extraem. Os principais passos são o cozimento das sementes e o seu amontoamento para que fermentem por cerca de 25 dias, e a extração da polpa. A polpa é então amassada em forma de bolas um pouco maiores do que uma bola de tênis, que são colocadas em uma superfície inclinada, no sol ou na sombra, durante algumas semanas para que o óleo escorra.

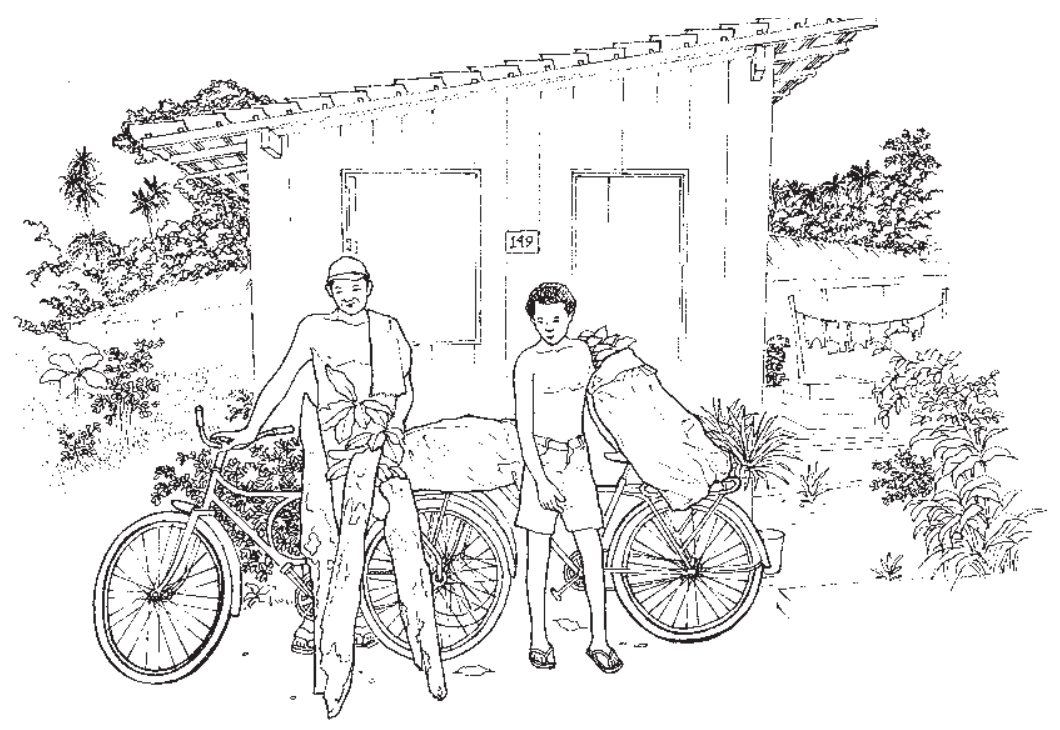

Os coletores da casca e sementes medicinais chegam a casa depois de um longo dia de trabalho. 


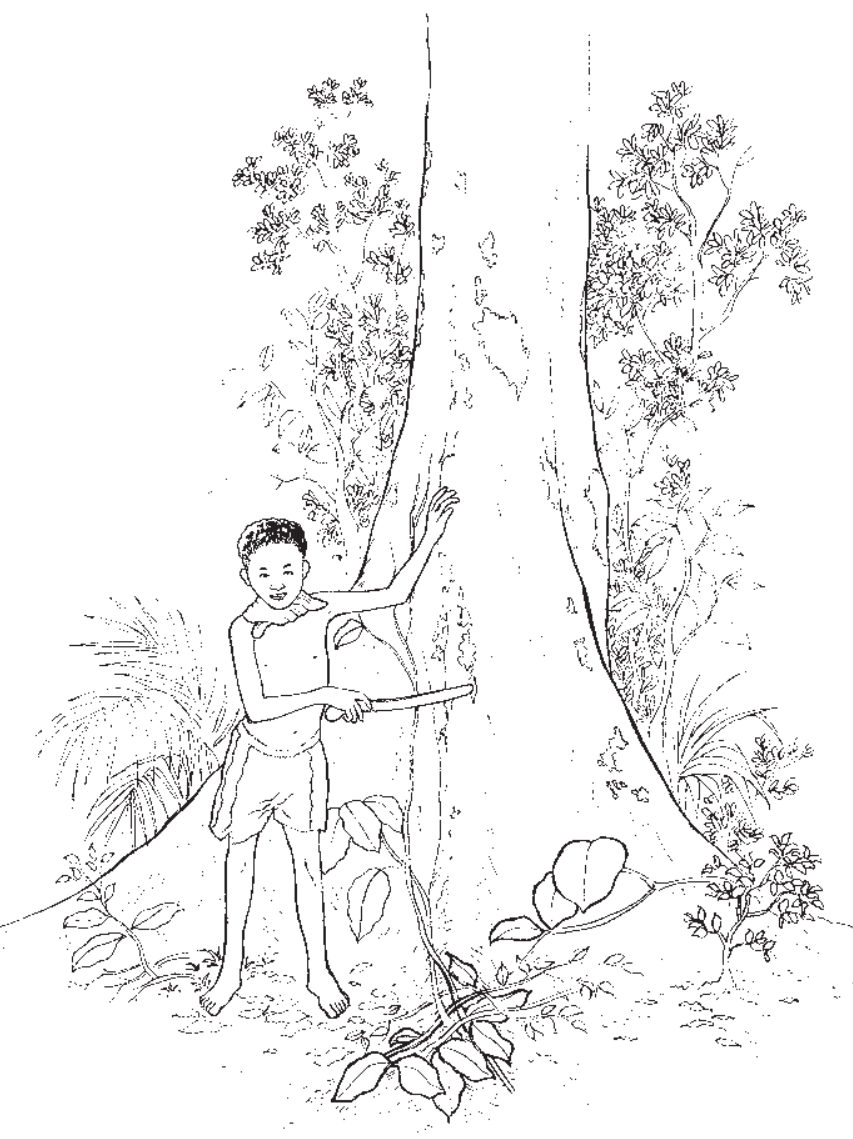

Nas regiões madeireiras, o número de árvores de andiroba está diminuindo drasticamente, limitando - acesso das famílias que usam óleo medicinal dessas árvores para os cuidados básicos da saúde.
Os processadores rurais de óleo dizem que 40 quilos de sementes rendem entre um e quatro litros de óleo. Por sua vez, o processamento industrial de 40 quilos de sementes pode render 8 a 12 litros de óleo. Enquanto o processamento tradicional demora cerca de 50 dias, pesquisadores da Universidade Federal do Pará garantem que, usando solventes e prensas, eles podem extrair óleo de andiroba em uma hora! Os astutos produtores domésticos de óleo, entretanto, questionam o poder de curar doenças do óleo processado industrialmente. Os pesquisadores, de fato, admitem que algumas das substâncias ativas obtidas durante o longo processo de fermentação não aparecem no óleo produzido rapidamente.

\section{Incompatibilidade de usos: madeira e óleo não se misturam}

A atrativa madeira marrom-avermelhada da andiroba não é atacada por cupins, provavelmente pela sua natureza amarga e oleosa. Por causa da beleza, qualidade e durabilidade da madeira, a andiroba é valiosa para a construcão de móveis finos, sendo por isso uma das primeiras espécies a serem derrubadas nas fronteiras do desmatamento. Entre os anos 1987 e 1997, a madeira de aproximadamente 30 ooo árvores de andiroba foi exportada a partir de Belém. Entretanto, a madeira exportada é somente uma pequena fração do volume total produzido - o consumo doméstico absorve 86 por cento de todas as toras produzidas no Brasil.

Pesquisas de campo sugerem que depois de 10 anos de crescimento a andiroba já produz sementes para a produç̃o de óleo e que após 18 a 25 anos já pode ser cortada para produzir a valiosa madeira. O crescimento do interesse pela produção tanto da madeira quanto do óleo medicinal está atiçando o interesse das comunidades no seu manejo.

Demonstrando visão e coragem exemplares, mulheres de Cametá, Gurupá, Porto de Moz e da Floresta Nacional do Tapajós estão se organizando para proteger do corte as árvores de andiroba, para assegurar que haverá sementes suficientes para produzir o óleo que cura para as suas famílias. 


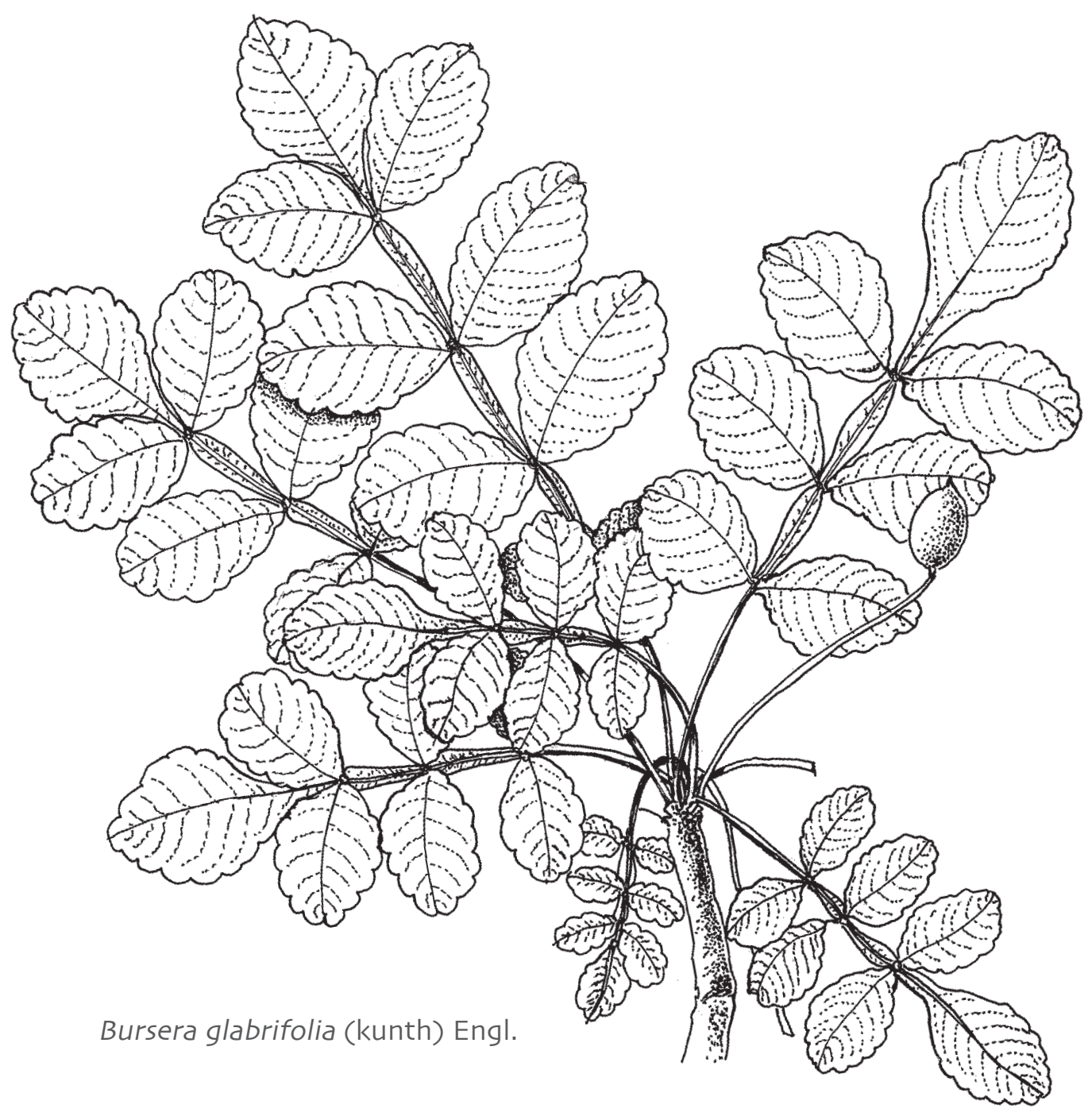

\section{Alebrijes, esculturas em madeira}

Caso mexicano apresentado por Silvia E. Purata, Berry J. Brosi e Michael Chibnik 


\section{Alebrijes: Figuras fantásticas esculpidas em madeira de copal}

O estado Mexicano de Oaxaca é famoso pela sua rica cultura e pelas tradições artísticas. Na região dos Vales Centrais, onde a cidade também de nome Oaxaca está localizada, uma nova forma de artesanato surgiu há pouco mais 20 anos atrás: os alebrijes, figuras coloridas de madeira esculpidas em forma de animais fantásticos, figuras míticas como sereias e dragões e seres meio humanos meio animais. A tradição informal de esculpir em madeira remonta a muitas gerasões, mas estas figuras são uma novidade criativa que não têm uma histórica significância cultural associada com as esculturas mais tradicionais. Em pouco tempo, entretanto, elas se tornaram uma das peças do artesanato mexicano mais

As figuras dos alebrijes surgem da imaginação dos vendidas nos Estados Unidos.

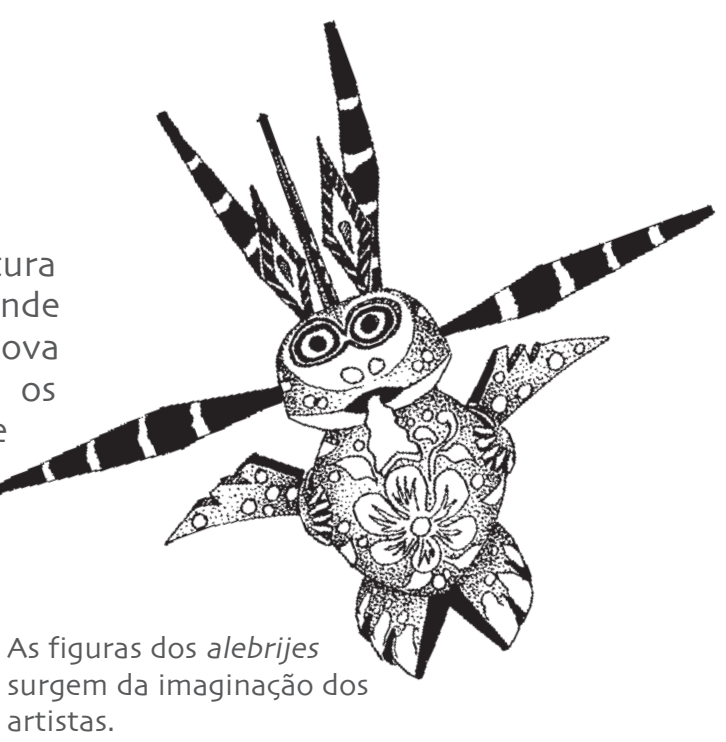

O artista Manuel Jimenez, da vila de San Antonio Arrazola, é considerado o criador do estilo de sucesso dos alebrijes. Seu estilo tem inspirado outros artesãos de vilas vizinhas, que agora produzem as esculturas em marcenarias familiares e as vendem diretamente para o público nas vilas de artesãos, mercados e lojas de artesanato de Oaxaca e outras cidades mexicanas. Elas também podem ser encontradas em lojas dos Estados Unidos e do Canadá, bem como na Europa, em países como a França e a Espanha.

A escultura de alebrijes aumentou dramaticamente a renda de muitas famílias na região dos Vales Centrais. Por conta dessa nova fonte de renda essas famílias têm construído casas, comprado carros, geladeiras e televisões. Muitas delas agora também podem mandar suas crianças para a escola secundária e usufruir de melhores serviços de saúde. Entretanto, a crescente demanda por madeira exige que mais e mais árvores de copal sejam cortadas nas áreas ao redor dos Vales Centrais, onde se encontram as principais comunidades de artesãos.

\section{A madeira da expressão artística}

A Madeira usada para esculpir alebrijes vem de árvores de várias espécies do gênero Bursera, da mesma família do incenso e da mirra (Burseraceae). As principais são Bursera glabrifolia, Bursera submoniliformis, e Bursera linaloe, conhecidas localmente como copales ou copalillo, e que são encontradas nas florestas áridas tropicais de Oaxaca e Estados vizinhos. Até pouco tempo, toda a madeira usada para esculpir era extraída de populacõos silvestres*. A colheita da madeira geralmente é muito simples porque as árvores são relativamente 
pequenas e a sua madeira é macia. As árvores são derrubadas com machado ou moto serra e os galhos cortados com facão.

Quando as árvores de copal desapareceram de Arrazola e San Martín Tilcajete (as duas principais vilas de escultores) devido à sua superexploração, os artistas passaram a comprar madeira em vilas vizinhas, até que as autoridades locais criaram leis para regular a sua exploração. Apareceram então os chamados 'copaleros', pessoas dedicadas à venda de madeira de copal para os artesãos, que geralmente vêm de outras comunidades. À medida que a oferta de madeira foi diminuindo a nível local ou que a leis passaram a ser aplicadas, os copaleros entenderam a abrangência da sua colheita para áreas cada vez mais distantes, provocando um significativo aumento de presos para os artesãos e uma correspondente diminuição dos seus lucros. A comercialização da madeira sem um plano de manejo autorizado pelo governo é ilegal, de acordo com a lei florestal mexicana. Assim, a colheita e a venda são geralmente feitas de maneira clandestina, a maioria dos carregamentos de madeira é feita através de estradas secundárias, principalmente à noite ou de madrugada.

\section{Transformando galhos em figuras fantásticas}

A criação das figuras envolve várias etapas. Quando a madeira está suficientemente seca, os artistas selecionam ramos que têm mais ou menos a forma das figuras que eles já têm em mente. As peças são então cortadas no tamanho ideal e descascadas, e usando um facão os escultores dão o formato inicial das figuras. Para dar o acabamento às suas criacões eles usam uma ampla variedade de ferramentas como formões, cinzéis, facões e canivetes. Os artistas aprendem suas habilidades básicas com outros escultores, mas a sua escolha

Em algumas

comunidades

de Oaxaca,

as famílias de artesãos atraem

os turistas

com letreiros imaginativos do lado de fora de suas casas.

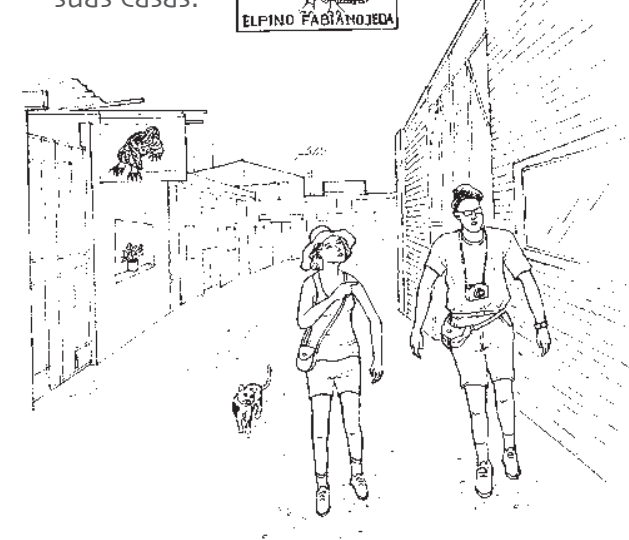
pessoal das ferramentas é principalmente resultado da sua experimentação individual.

Muitas das esculturas têm partes removíveis como orelhas, asas e caudas, feitas em peças separadas de madeira. Essas peças são fixadas às figuras com pregos ou cola, ou simplesmente encaixadas em ranhuras especialmente feitas para elas. Essa característica permite aos turistas desmontar e transportar facilmente as peças, particularmente as figuras complexas com muitas partes.

Quando a demanda por alebrijes aumentou na década de 1980, os escultores passaram a contar com a ajuda das suas esposas e filhos na tarefa de lixar e pintar as peças. Rapidamente, a escultura transformou-se numa atividade familiar, realizada em oficinas simples. Uma vez esculpidas, as figuras são secas ao sol para reduzir a umidade da madeira. Às vezes, elas são antes ensopadas com gasolina para protegê-las contra insetos. Após a secagem, as esculturas são lixadas para que fiquem bem lisas antes de serem pintadas. 
A maioria das figuras são pintadas em dois estágios. Primeiramente é aplicada rapidamente uma demão de fundo, usando-se uma esponja ao invés de um pincel. Depois, as esculturas são decoradas com pontos, linhas em forma de ondas, figuras geométricas e outras formas, usando pincéis de diferentes tamanhos. A aplicação de uma demão de fundo é uma tarefa fácil, às vezes realizada por crianças ou pelos aprendizes. A decoração, entretanto, é bem mais difícil e é deixada para os artesãos habilidosos. Até cerca de 1985, a maioria dos pintores usava anilina, um pigmento em pó que é misturado à água. Alguns escultores ainda usam esse produto, mas a maioria deles passou a usar tintas acrílicas (vinil), as mesmas usadas para pintar casas, que são mais brilhantes e espessas e escorrem menos.

\section{Tendências}

Como parte de um esforso para melhorar o manejo de espécies de Bursera em Oaxaca, os pesquisadores têm trabalhado com comunidades de artesãos e produtores, documentando as principais rotas de comercialização e estudando a demanda para estimar o volume de madeira que está sendo extraído. Ao mesmo tempo, se iniciou uma pesquisa sobre o manejo sustentável* das espécies na floresta na comunidade oaxacana de San Juan Bautista Jayacatlán. A pesquisa envolve um extenso trabalho de inventário e de estudos de crescimento (do diâmetro das árvores) que permitem calcular o volume de madeira que pode ser colhido periodicamente sem pôr em risco as espécies e a própria floresta.

Com a colaboração dos residentes de Jayacatlán, foi desenvolvido um plano de manejo florestal comunitário para promover a exploração sustentável* de Bursera. Esse foi o primeiro programa comunitário de manejo que os pesquisadores desenvolveram para uma floresta tropical árida no México, uma iniciativa que demonstra como a pesquisa científica responde a necessidades locais, com benefícios para as comunidades locais e para o meio ambiente. Felizmente, as árvores de copal apresentam um crescimento rápido e são relativamente abundantes nas florestas naturais de Jayacatlán. Com a exploração

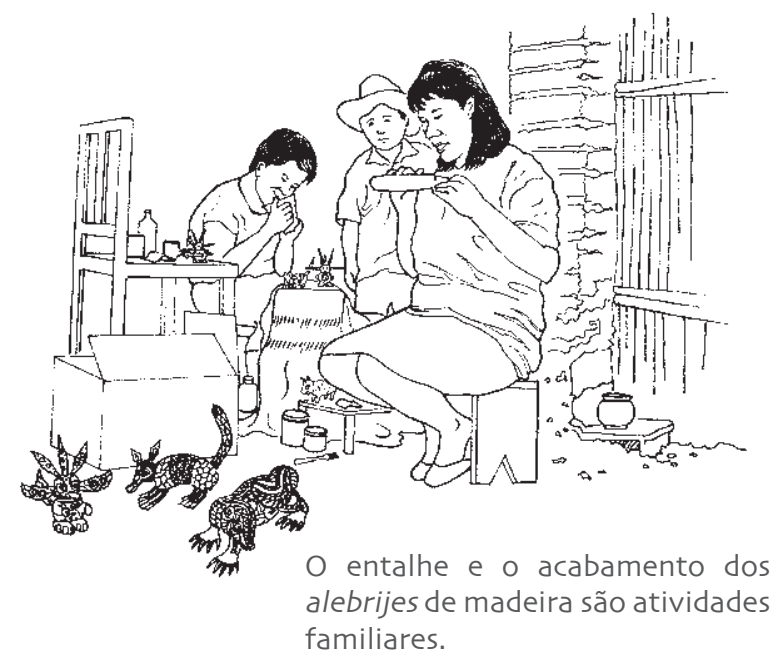
sustentável, a regeneração natural será suficiente para atender à demanda de madeira sem a necessidade de se recorrer ao plantio de árvores.

O plano de manejo está agora em seus primeiros estágios de implementação. Os pesquisadores esperam usar Jayacatlán como um modelo para outras comunidades produtoras, uma vez que a madeira que ali está sendo colhida não é suficiente para abastecer a todas as comunidades de escultores. Com outras comunidades se engajando na producão sustentável de madeira, os turistas que vêm ao México poderão continuar a desfrutar dos coloridos monstros, macacos e ratos enquanto passeiam pelos mercados e praşas. A esperança é que essas iniciativas de manejo permitam aos escultores continuarem a usufruir dos benefícios e do prazer da sua arte e que as espécies de Bursera continuem a crescer nas florestas locais. 


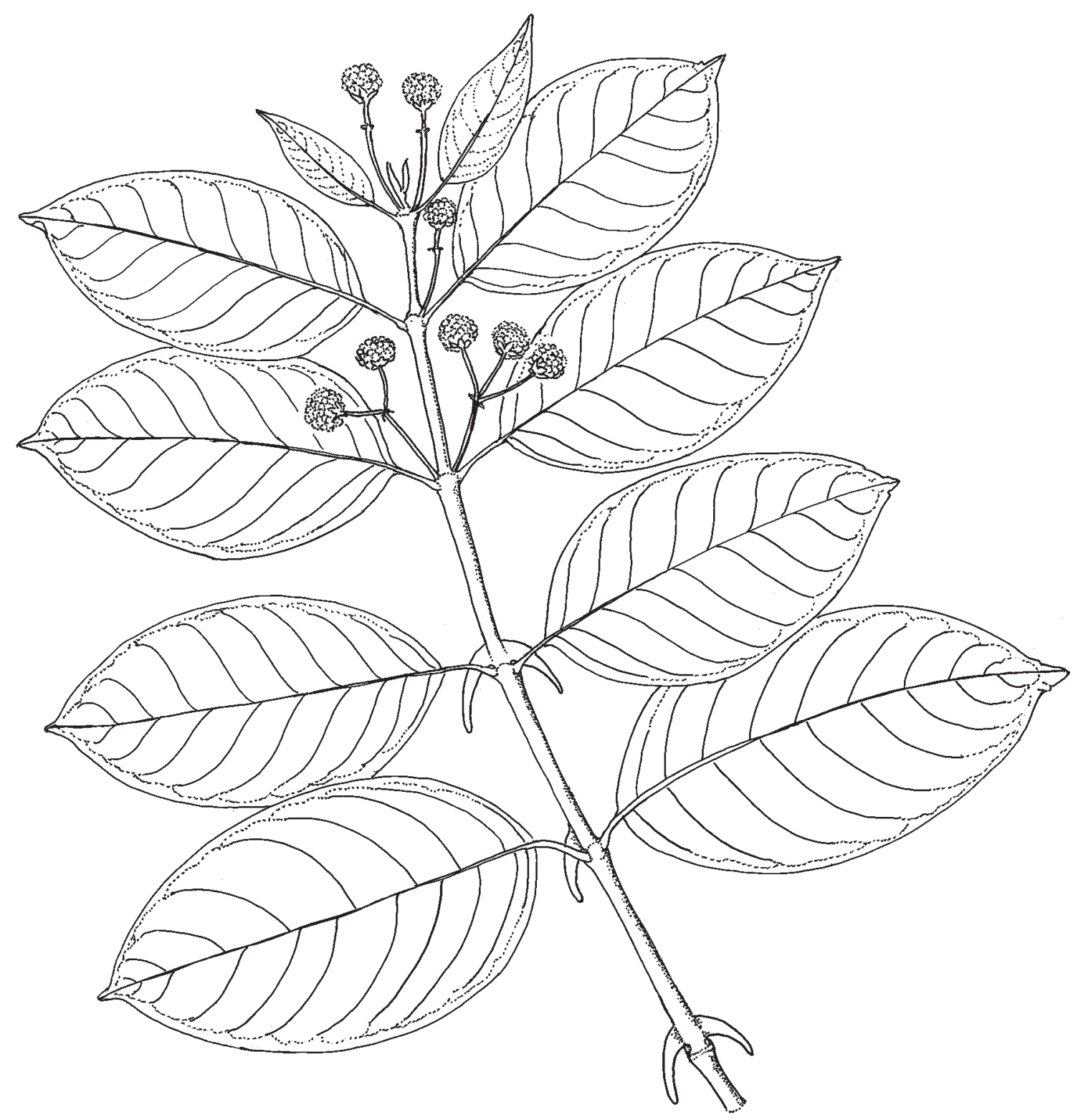

Uncaria tomentosa (Willd. ex Roem. \& Schult.) DC.

\section{Unha-de-gato, cipó medicinal}

Caso peruano apresentado por Wil de Jong e Walter Nalvarte 


\section{Unha-de-gato: Cipó medicinal amazônico}

Durante séculos, os povos indígenas* Cashibo, Conibo, Shipibo e Ashaninka do Peru utilizaram a casca de um cipó chamado unha-de-gato (Uncaria tomentosa) para preparar uma bebida medicinal. Hoje essa bebida ainda é consumida na forma decocsão*, fervendo a camada interior da casca do talo o das raízes. O líquido resultante é consumido por conta das suas propriedades curativas, ou misturado à aguardente. As decocsões da casca são consideradas como tendo um efeito antiinflamatório* e que atuam como estimulante do sistema imunológico*. Em comunidades rurais das florestas úmidas tropicais ou de áreas adjacentes a elas na América do Sul e Central, onde crescem, os especialistas em plantas medicinais afirmam que a unha-de-gato pode curar tumores.

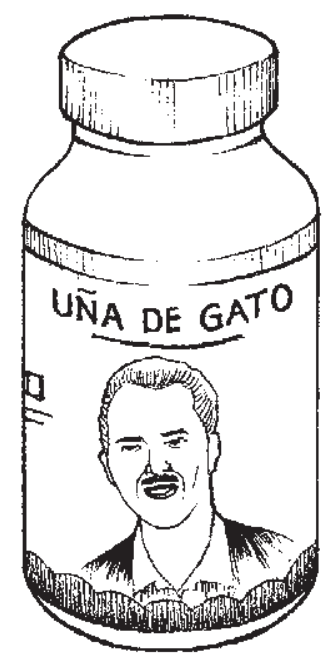

Hoje, a unha-de-gato é vendida em muitas formas diferentes no Peru e é exportada para mais de 30 países.

\section{A pesquisa e a publicidade}

O uso indígena da unha-de-gato atraiu a atenção de pesquisadores e cientistas do mundo ocidental que começaram a analisar suas propriedades medicinais no início da década de 1970. Os estudos realizados nos últimos 30 anos conseguiram identificar

70 compostos ativos e confirmaram suas propriedades antiinflamatórias e estimulantes do sistema imunológico. Outras propriedades medicinais ainda estão por ser estudadas. Entretanto, vários relatos do sucesso de tratamentos com essa planta têm estimulado o aumento do seu uso na Europa e América Latina, e até mesmo entre alguns grupos indígenas do Peru, que até pouco tempo desconheciam os seus benefícios terapêuticos.

A exportação de unha-de-gato do Peru comesou na década de 1970 e aumentou significativamente durante a década de 1990, depois da divulgação dos resultados de estudos referentes aos usos medicinais da planta. Em 1991, depois que um conhecido ator mexicano declarou que havia conseguido curar-se de um câncer de próstata através do uso da unha-de-gato, a popularidade dessa liana aumentou de forma dramática. Desde o início da década de 1990, a unha-de-gato tem sido utilizada tanto no Peru como em países europeus como um tratamento complementar na batalha contra o câncer e a AIDS, além de outras enfermidades que atacam o sistema imunológico. No final da década passada, a casca da planta era vendida nas principais cidades do Peru e exportada para outros 30 países, incluindo Áustria, Bolívia, Equador, Hong Kong, Itália e Estados Unidos. Em 1995, o valor das exportaşões superou os 3,3 milhões de dólares. 


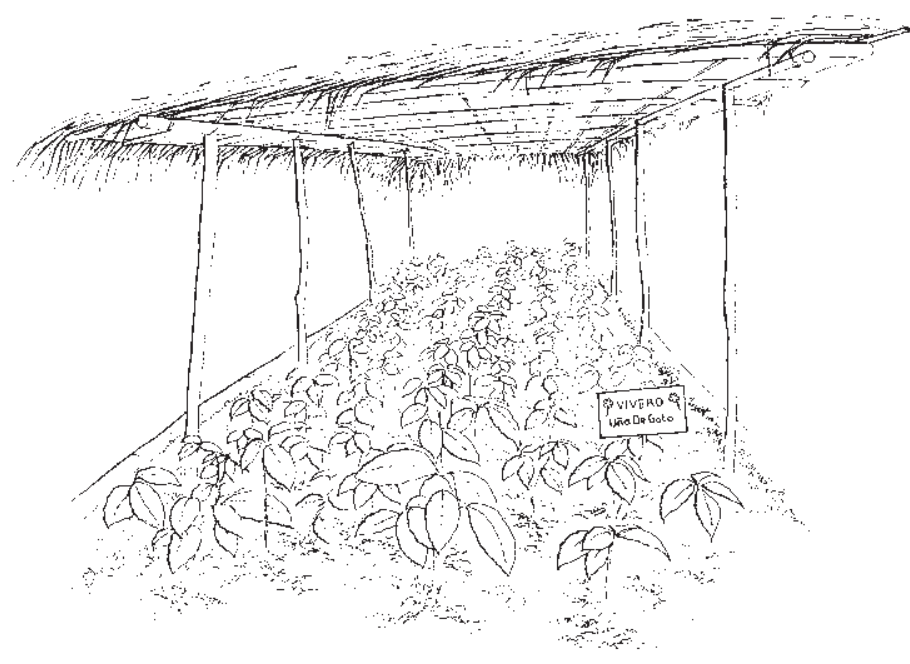

A unha-de-gato às vezes é cultivada para atender a demanda por esta casca medicinal.

\section{Silvestre* ou cultivada?}

A unha-de-gato cresce em florestas primárias* desde o Paraguai até Belize e geralmente ocorre em altitudes entre os 400 e 800 metros acima do nível do mar. A planta tem esse nome porque tem espinhos que parecem com as garras de um gato. Com elas, a planta consegue trepar até 30 metros de altura, atingindo o dossel*. Um cipó similar, chamado Uncaria guianensis, tem espinhos um pouco mais curvos e por isso não consegue se apoiar com tão bem nos ramos das árvores. Esse cipó, que cresce em áreas perturbadas próximas a rios e estradas, também tem propriedades curativas. Ambas as espécies são utilizadas e comercializadas e, com freqüência, são confundidas botanicamente.

Vários organismos governamentais do Peru, assim como empresas do setor público e Privado, têm se dedicado a pesquisar a reprodução da unha-de-gato. Os resultados têm demonstrado que a Uncaria tomentosa necessita desenvolver-se entre árvores que permitam o seu crescimento vertical. Entretanto, as plântulas* não crescem bem se há muita sombra, preferindo áreas da floresta aonde chegue a luz do sol. Essa é uma das razões pelas quais este cipó se reproduz mais vigorosamente em florestas perturbadas, onde clareiras são criadas. Os experimentos sugerem que a unha-de-gato necessita de aproximadamente 10 anos para chegar à maturidade, quando o talo atinge 10 centímetros de diâmetro. Quando cresce naturalmente nas florestas, sua densidade* é de duas a oito plantas por hectare.

A unha-de-gato é coletada em florestas primárias, quando se trata de Uncaria Tomentosa, e em matas secundárias*, no caso da Uncaria guianensis. Depois de uma explosão nas vendas na década de 1990, alguns agricultores na Amazônia peruana começaram a semeála em matas secundárias e hortas familiares para aumentar a oferta e, ao mesmo tempo, sua renda. Entretanto, a maior parte da produção ainda vem de populações silvestres da planta.

\section{A cadeia produtiva}

Os coletares de unha-de-gato cortam os cipós maduros, que são descascados e levados de para as suas casas. Ali fazem o processo de secagem, limpeza e corte dos ramos em pequenos pedaşos para venda. A casca pode ser encontrada na seção de plantas medicinais nos mercados de cidades como Iquitos, Pucallpa e Lima, a capital do Peru. O processamento mais avançado é feito em Lima, onde além de vender a casca os comerciantes a cortam 


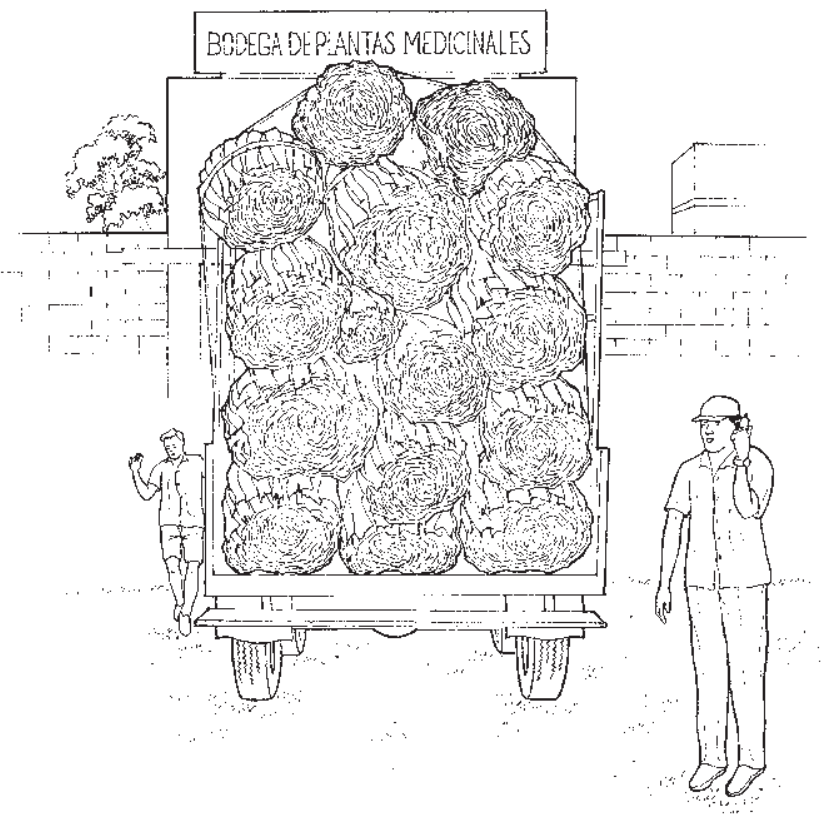

Após a coleta, a casca da unha-de-gato étransportada para os centros de recebimento.

em pedaços menores, que são moídos até serem convertidos em pó. Em seguida, o pó é colocado em saquinho tipo chá ou em cápsulas. Esses produtos são vendidos mais tarde em farmácias e supermercados em todo o país. Em nível internacional, a casca de unha-de-gato é comercializada na forma semiprocessada. Usualmente, um comerciante local compra a casca de diferentes coletadores para vendêla depois a outros compradores no exterior.

Empresas botânicas e medicinais em Lima têm desenvolvido uma série de produtos com base na unha-de-gato. Além de moer a casca seca, também congelam os extratos, facilitando assim a sua posterior exportação e garantindo a consistência de seus componentes ativos.

A maior parte dos coletadores de casca trabalha como diaristas. Normalmente, vêm de famílias indígenas ou migrantes que vivem no interior das florestas peruanas próximas aos rios, seu principal meio de transporte. Essas famílias praticam a agricultura, pesca, caça e coleta de recursos florestais como a unha-de-gato, tanto para consumo doméstico como para a sua comercialização em mercados locais.

\section{Tendências}

Entre 1995 e 1997, as vendas de casca de unha-de-gato aumentaram consideravelmente, embora desde essa época estejam diminuindo. Essa queda nas vendas pode estar relacionada com uma saturação do mercado. Entretanto, algumas pessoas consideram que o ingresso de produtos de baixa qualidade no mercado pode ter reduzido a confianşa dos consumidores. Por exemplo, além da Uncaria tomentosa, a espécie $U$. guianensis, que pode ser encontrada com maior facilidade, também foi coletada e em certas ocasiões ambas foram vendidas como unha-de-gato.

Apesar de uma diminuição nas vendas, a unha-de-gato continua sendo um produto importante tanto do ponto de vista médico como econômico. As análises químicas da planta têm confirmado a existência de compostos ativos e os mais entusiastas afirmam que a espécie tem potencial para o desenvolvimento de medicamentos modernos. Considerando que a unha-de-gato se regenera bem em matas secundárias e áreas degradadas, a produção poderia satisfazer a crescente demanda - caso o público se convença que ela realmente funciona. 


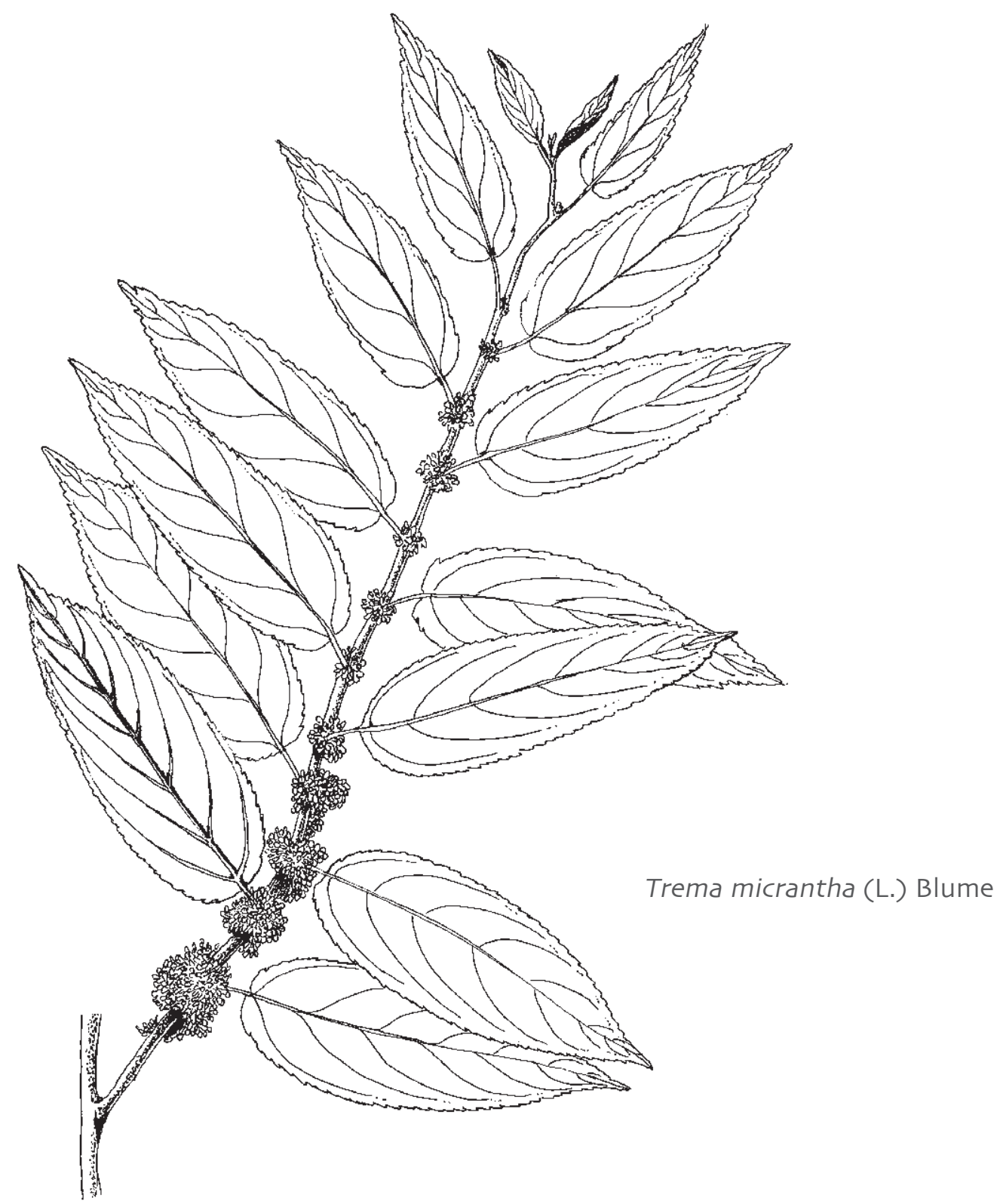

\section{Amate: papel de casca de árvore}

\section{Caso mexicano apresentado por Citlalli López}




\section{Amate: Um mercado moderno para}

um papel tradicional

Os turistas que visitam La Ciudadela, o maior mercado de artesanato da Cidade do México, passeiam entre as longas vielas abarrotadas de maravilhosos tecidos, cerâmicas, máscaras de madeira e pilhas de papel amate, feito de casca de árvore e ilustrado com pinturas coloridas de flores, pássaros e cenas da vida no campo. Para muitos turistas esse é um perfeito souvenir: leve, fácil de carregar, e mais barato que outras peças de artesanato. Mas é mesmo a beleza irresistível do amate que vai chamar a sua atenção.

O papel de casca de árvore tem uma longa história, havendo evidência da sua manufatura no México desde o ano 300 d.C. No século $X V$, antes da chegada dos espanhóis, sacerdotes usavam papel amate para confeccionar as vestes cerimoniais e nas oferendas aos deuses. Livros escritos em papel amate, conhecidos como 'códices', registravam a história e a mitologia, enquanto os calendários guiavam as atividades agrícolas e os rituais. O papel amate também era usado para pagar alguns tributos. A demanda por esse papel era tão grande que os habitantes de cerca de 40 comunidades dedicavam-se inteiramente a sua fabricaşão.

Como muitos outros aspectos da cultura indígena*, a produção do papel amate foi proibida pelos colonizadores espanhóis. Para impor a sua religião cristã, os espanhóis baniram as cerimônias rituais indígenas e o uso do papel, que era associado à capacidade de governar. Os espanhóis usavam o seu próprio papel feito de algodão, que vinha da longínqua Europa, cruzando o Oceano Atlântico para atender às demandas no novo mundo.

\section{A fusão de duas tradições indígenas}

A despeito da proibição, alguns grupos indígenas continuaram a fazer secretamente o papel amate, mantendo viva essa tradição. O povo Otomi, da vila de San Pablito de Puebla, até hoje manufatura o papel de maneira tradicional para cerimônias rituais. Cerca de 30 anos atrás, os Otomi juntaram a sua técnica de fabricação do papel com a tradição na decoração de peças de artesanato em cerâmica do povo Nahua do estado de Guerrero. Embora as suas comunidades estejam distantes uma da outra, os dois grupos produzem e decoram produtos amate para venda, combinando aspectos do seu trabalho artístico tradicional, mas sempre experimentando novos estilos, formatos e usos do papel. O papel de casca de árvore era originalmente feito somente em folhas lisas, de tamanho padrão $(60 \times 40 \mathrm{~cm})$, mas agora existe uma variedade de tamanhos e produtos finais, inclusive papel para escrever, brochuras e abajures. As folhas maiores podem ser usadas até mesmo como papel de parede ou para cobrir móveis.

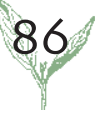




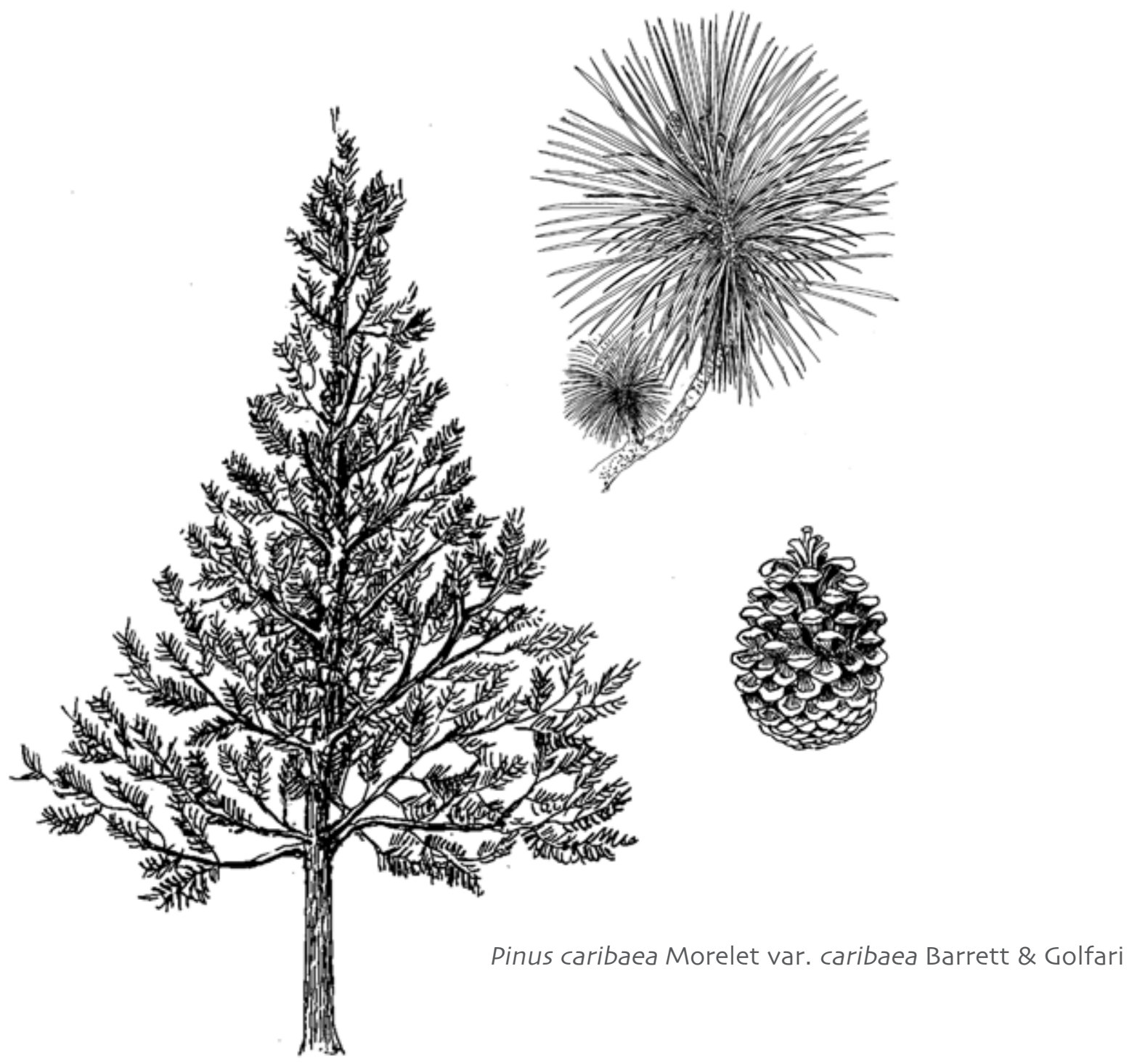

Resina de pínus

Caso cubano apresentado por Ynocente Betancourt Figueras e María Josefa Villalba Fonte 


\section{Resina de pínus: Terebintina, tintas e vernizes de árvores cubanas}

Da próxima vez que você usar terebintina para limpar a tinta acrílica de um pincel, lembre-se de agradecer às árvores de pínus pela resina que produzem! A terebintina é um dos produtos fabricados a partir da espessa e translúcida resina extraída dessa conífera*. Diferentes espécies do gênero Pinus ocorrem naturalmente no hemisfério norte e têm migrado para várias partes do mundo, incluindo a Europa e a Ásia. Hoje, as plantações de pinus ocupam milhares de hectares de terra em países onde nunca existiram, contribuindo para o desenvolvimento econômico e social dos seus povos.

Em Cuba, o Pinus caribaea, ali chamado de pínus ou pinheiro macho, é utilizado tanto pela sua madeira como pela sua resina. A madeira é empregada para muitos propósitos na construção de casas, da estrutura às portas e janelas, além de barcos, postes, entrada de minas e móveis. Na zona rural, os agricultores utilizam as toras para todos os tipos de construş̃os.

A partir da resina crua se obtém dois derivados: o colofônio e o óleo de terebintina ou aguarrás. Esses produtos têm alta demanda na indústria química, principalmente para a produção de tintas, vernizes, adesivos e desinfetantes. A maior parte da resina produzida em Cuba é exportada para vários países, incluindo o México, Índia e Espanha. Uma tonelada de resina crua tem um valor no mercado internacional de 350 dólares, quantia que chega a triplicar depois de processada.

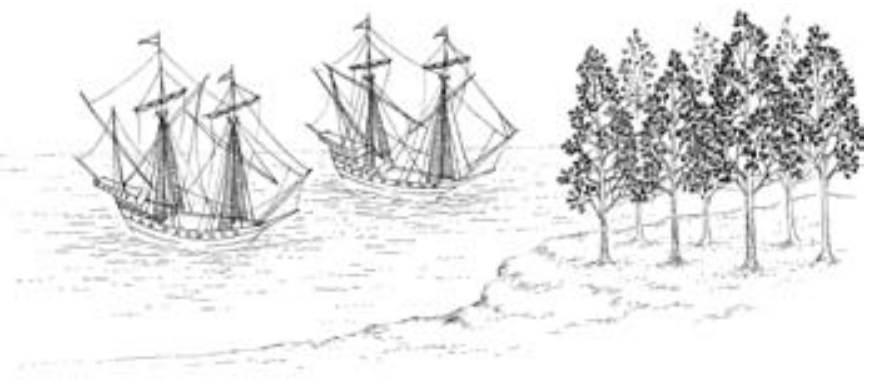

Cristóvão Colombo chegou à ilha de Cuba em 28 de outubro de 1492, durante a sua primeira viagem rumo ao oeste.
Uma ilha tropical cravejada de pinheiros

O uso das árvores de pínus em Cuba tem uma longa história, que se estende da era pré-colonial até os dias de hoje. Sabe-se que no Caribe, as paisagens salpicadas com pinheiros sempre verdes chamaram a atenção dos primeiros exploradores espanhóis. Durante a sua primeira viagem ao continente americano, Cristóvão Colombo fez as seguintes observaš̃es no seu diário de bordo:

"Os grumetes gritavam que podia ver pinheiros. Olhei para as montanhas, e vendo pinheiros tão grandes e maravilhosos, eu poderia somente estimar a sua altura e retidão ... certo de que se poderiam construir navios com um infinito número de pranchas e mastros para as maiores naus da Espanha."

Desde então, e durante cerca de 200 anos, os pinheiros cubanos foram utilizados para a construção dos barcos que integraram a famosa frota espanhola, que permitiu a expansão do império para a América e outras regiões do mundo. 
O Pinus caribaea é parte da vegetação natural de Cuba onde pode ser encontrado principalmente na província de Pinar del Río. Ali, há mais de 100 ooo hectares da espécie, 70 por cento dos quais são plantados. Nessa província, cerca de 200 famílias, organizadas em brigadas, participam efetivamente da coleta manual da resina de pínus. Atualmente, o salário médio em Cuba é de 300 pesos cubanos, mas os coletores de resina chegam a ganhara até três vezes mais. Um coletor pode produzir 1,5 a 2 toneladas de resina em um mês, recebendo 663 pesos cubanos por cada tonelada.

Olprocessamento industrial da resina comesou em meados de 1980. No primeiro ano, a produsắo foì de 70 toneladas, e cresceu ano após ano até alcançar a produção de 1 ooo toneladas. No anos 1990, uma forte crise econômica derrubou a produção para menos de 200 toneladas anuais. Entretanto, o setor se recuperou a partir do ano 2000 e a produção tem se mantido nas 1200 toneladas por ano. Até 2005, houve uma produção total de 16800 toneladas, das quais cerca de 80 por cento foi exportada.

As flutuaçóes na produção de resina e o desenvolvimento de nova tecnologia de processamento é parte da históría econômica e política recente de Cuba. O embargo de comércio imposto pelos Estados Unidos e o colapso do mercado soviético dificultaram a importação ou exportação de produtos e tiveram sérias conseqüências, principalmente nas áreas da saúde e nutrisão. Não obstante, graşas ao esforso dos cidadãos e ao apoio do governo, em especial no campo da pesquísa, Cuba conseguiu tornar as suas atividades agrícolas e industriais mais sustentáveis tanto social como ambientalmente. A indústria da resina de pínus é um exemplo desse sucesso.

Nos últimos anos, os esforços no campo da pesquisa se concentraram na aplicação de estimulantes orgânicos (levedura de cerveja) para aumentar a produtividade por árvore e por coletor bem como na obtencão de produtos derivados da resina para cobrir necessidades nacionais e para a exportação, utilizando tecnologias desenvolvidas no país. Como resultado, os níveis de produção têm aumentado, e a expectativa é de que se alcancem as 5000 toneladas anuais nos próximos cinco anos.

\section{Madeira e resina: Produção compatível}

Os pinheiros estão prontos para a extração da resina praticamente ao mesmo tempo em que atingem o diâmetro mínimo para serem aproveitados para a produção de madeira: 30 centímetros. Normalmente, se faz a 'resinagem' entre dois e quatro anos antes do corte para garantir uma boa colheita de resina e também de madeira.

O método de resinagem consiste em fazer um sulco central no tronco a uma altura de 1,6 metros do chão e outros sulcos menores, inclinados em forma de " $V$ ", que formam com o sulco central um desenho tipo espinha de peixe. Para que a árvore possa ser resinada, a cada ano é descascada uma secsão do tronco com aproximadamente 60 centímetros de comprimento, chamada painel de resinagem. A largura do painel depende do diâmetro da árvore; somente são resinados dois tersos da circunferência, deixando um terşo sem descascar, para que a árvore continue realizando as suas funções fisiológicas. Após aberto o painel de resinagem, 
a resina é extraída durante 45 semanas. Para estimular o fluxo de resina é feito um corte central, abaixo do qual é colocada uma bica de metal e uma vasilha coletora. A cada semana é feito um novo corte, com aproximadamente 5 milímetros de profundidade e que vai até o canal central. Feito o corte, a resina comesa a brotar do tronco, podendo fluir por até 25 horas, escorrendo pelo canal central até a vasilha coletora. Depois, a resina é depositada em tonéis de 200 quilos para ser transportada até o local de processamento ou até as empresas exportadoras.

Uma única árvore de Pinus caribaea pode render até 4 quilo de resina por ano, produção equivalente a duas toneladas de resina por hectare. Cada resinador é responsável por uma área de produção que varia de seis a dez hectares (de 2000 a 4000 pinheiros) dos quais serão coletados de 12 a 18 toneladas de resina anualmente.

\section{Uma indústria sustentável para o Pinus caribaea}

Todos os extratores têm vínculos diretos com a Empresa Florestal Estatal, encarregada do sistema de pagamento, e com a Empresa Comercializadora Cubana, que os mantêm informados sobre os preşos da matéria-prima, as condições de venda e o processo de comercialização. O aproveitamento contínuo e sustentável da madeira e da resina é baseado na correta aplicaşão de tecnologias e na conservação dos pínus. Os extratores têm se beneficiado com emprego estável e a sua capacitação garante a alta qualidade do trabalho. Manter essas condicões contribuirá para assegurar o futuro sustentável da indústria.
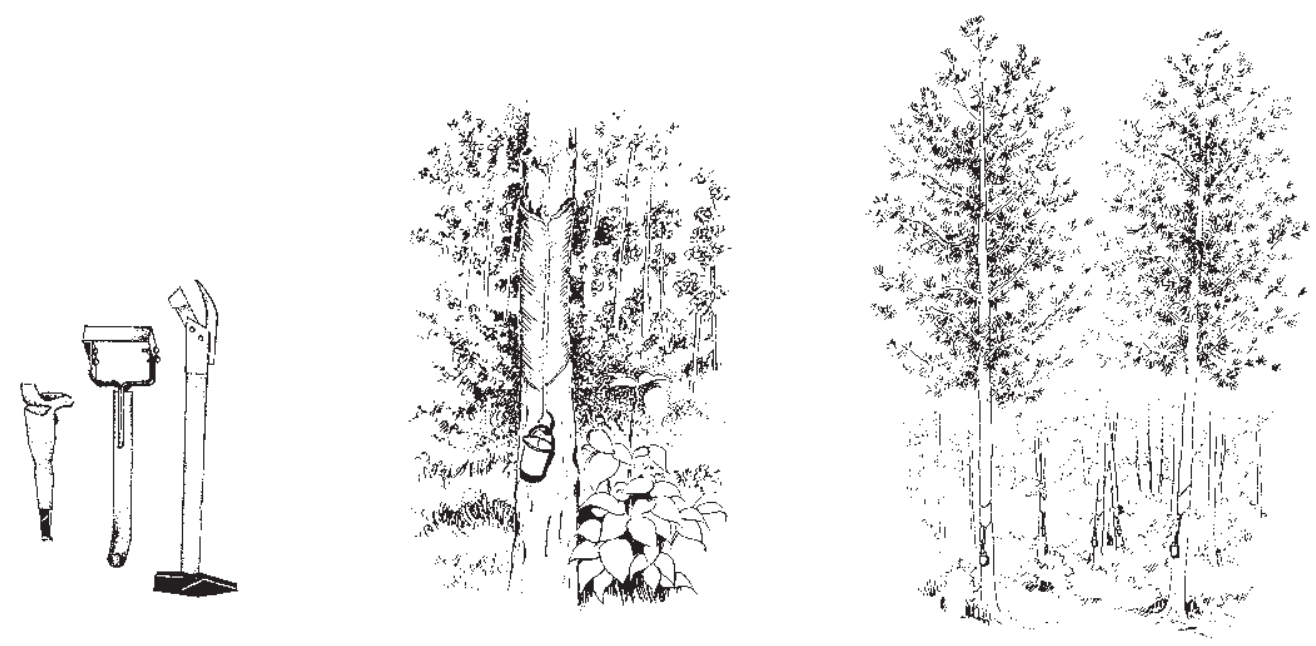

A extração da resina é realizada com ferramentas rudimentares, que incluem um descascador e facas com diferentes tamanhos e formatos para realizar as incisões no tronco. Esses cortes estimulam o fluxo de resina que escorre até a vasilha coletora. 


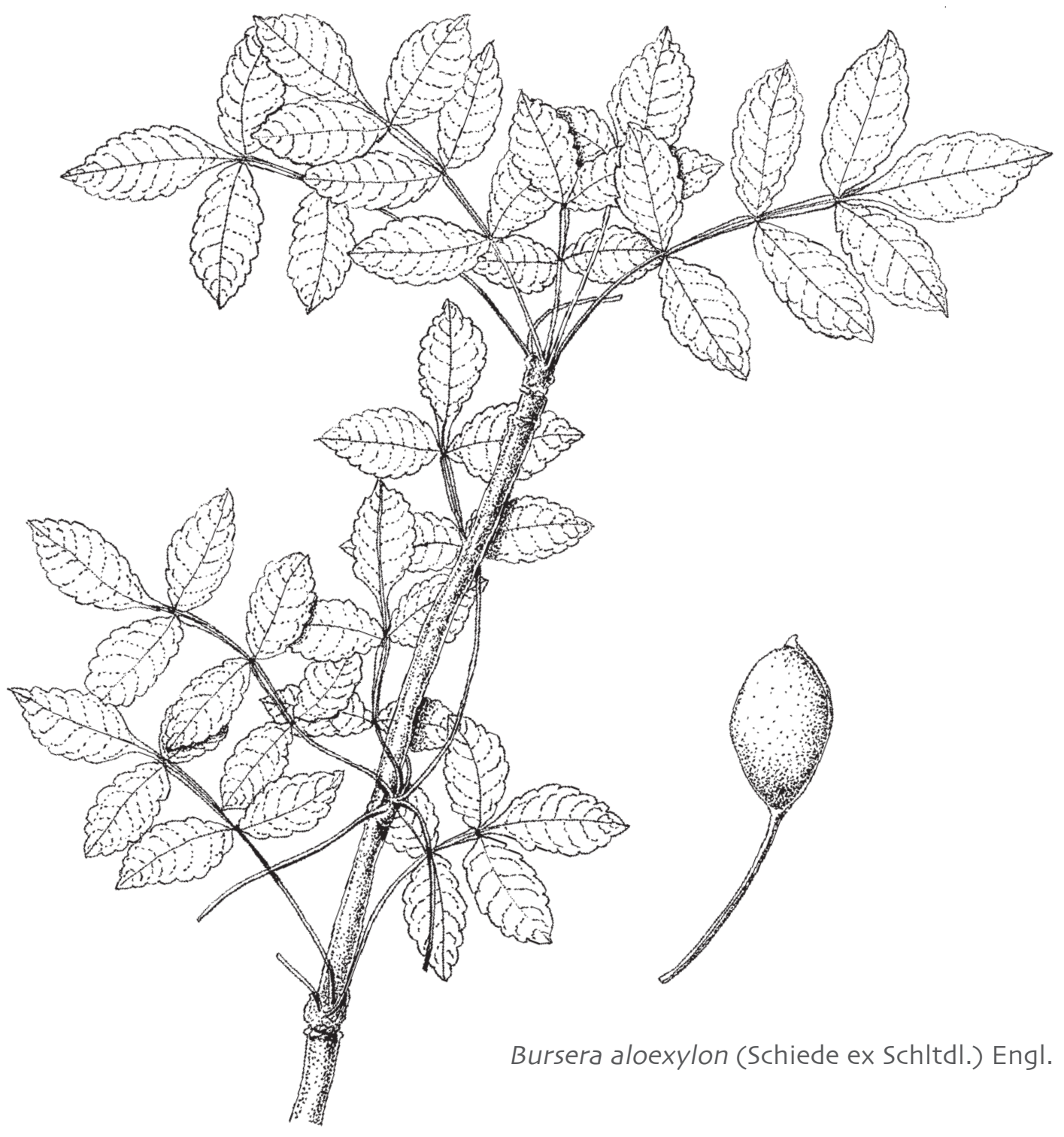

\section{Linalol, esculturas em madeira / óleo essencial}

Caso mexicano apresentado por Paul Hersch-Martínez 


\section{Linalol: Ferido, o lenho derrama lágrimas de perfume}

Quando você toma em suas mãos uma caixa de madeira feita no México, você está prestes a ter uma agradável surpresa. Ao abrir a tampa de uma dessas maravilhosas peças do artesanato mexicano, decoradas com desenhos coloridos de coelhos, pássaros e flores, você é envolvido pelo delicioso perfume da essência de linalol. Entretanto, por detrás dessa qualidade e delicadeza se encontra, em contraste, uma precária situação compartilhada por coletores, artesãos e árvores.

Essas caixas tão características são feitas com madeira da árvore do linalol, que pertence a um grupo de árvores conhecido como 'copales' (do gênero Bursera), muito valorizadas no México desde os tempos pré-hispânicos pelos seus agradáveis perfumes e usos em rituais. O segredo do linalol é que, ao contrário de muitas copales, ele quase não exsuda resinas quando o seu tronco é ferido. Ao contrário, os seus óleos aromáticos se acumulam dentro da madeira, mantendo a sua fragrância. Essa característica torna o linalol valioso tanto pela sua madeira quanto

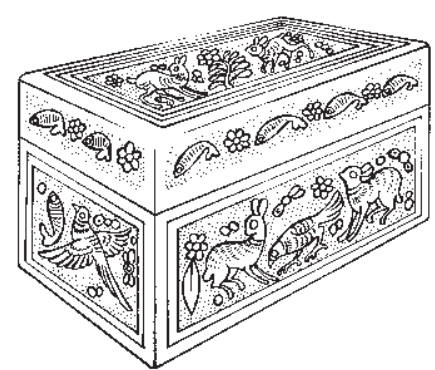

Caixas de madeira ricamente decoradas, feitas com a madeira do linalol ou impregnadas com esse óleo essencial, perfumam suavemente o seu conteúdo. pelo seu óleo essencial.

Em Olinalá, no estado do Guerrero, onde o artesanato tradicional em madeira é fabricado, o óleo essencial de linalol é passado dentro de caixas de madeira para dar-lhes um agradável perfume. O óleo também é usado para perfumar roupas assim como para tratar dor de cabeça e picadas de escorpião. Como a fragrância também repele traças, baús feitos com essa aromática madeira têm sido tradicionalmente usados para guardar roupas especiais, como vestidos de noiva.

No século XIX, a madeira de linalol era vendida para a França e para a Inglaterra, onde o seu óleo era destilado. Desde então e durante a primeira metade do século XX, o México passou a destilar o óleo e a exportá-lo para as indústrias de perfume da Europa e dos Estados Unidos. Isso era possível por conta da existência de uma rede de destiladores em diversas comunidades do vale do rio Balsas. Desses, restam hoje não só a memória dos que eram crianças e testemunharam aquela indústria, mas também vestígios dos alambiques em diversas comunidades dos estados de Guerrero, Puebla, Morelos, Oaxaca, Michoacán e Colima.

A producão do óleo de linalol, entretanto, implicava o corte das árvores ao utilizar a madeira como matéria-prima e os programas de reflorestamento desenvolvidos na metade do século passado não foram suficientes para compensar a intensiva exploração iniciada anteriormente. Assim, diante da enorme demanda de óleo, o número de árvores declinou drasticamente.

Em 1911, uma companhia inglesa introduziu o linalol na região ocidental da Índia, estabelecendo plantasões em Bangalore e Kerala. Depois de alguns anos, óleo produzido nessa região substituiu o do México no mercado mundial de óleo de linalol.

\section{A extração tradicional}

No México, o preparo da madeira para a colheita envolvia uma técnica conhecida como cala, que consistia em fazer incisões diagonais com 3 a 5 centímetros de profundidade no tronco e galhos 
mais grossos da árvore. Tradicionalmente, esse processo era feito durante a lua cheia, no final da estação chuvosa, para reduzir a possibilidade do apodrecimento dos troncos por excesso de umidade. Nos meses que se seguiam, os cortes faziam a resina oleosa se acumular dentro da madeira. Apareciam então manchas avermelhadas conhecidas como 'mapa' ou 'coração' e seis a sete meses mais tarde a árvore era cortada para extrair a madeira perfumada.

Hoje, entretanto, esses procedimentos raramente são seguidos; a necessidade de dinheiro dos campesinos os leva a cortarem as árvores para venda em Olinalá antes de formarem o "coração". Mesmo assim, devido às pressões do mercado e dos decrescentes estoques de linalol as caixas estão sendo feitas com madeira de outras espécies de copales ou mesmo de pinus, aromatizadas às vezes com óleo essencial obtido de árvores de linalol derrubadas sem autorização florestal, e frequentemente adulterado.

\section{Artesanato sem igual}

A madeira do linalol vendida para as carpintarias em Olinalá é transformada em caixas e baús de diferentes tamanhos dentro de oficinas familiares. As peças recebem primeiramente uma base de cor chamada de 'maque', utilizando minerais arenosos, tecoxtle, aplicados com uma cola de veado, além do óleo de sálvia (Salvia hispanica), agora substituído por óleo de linhaça (Linum usitatissimum), de menor qualidade. A cor do maque vem de um pó mineral chamado tlapilol, preta quando este é misturado com carvão de azinheira (Quercus ilex) ou carmim, quando misturado com a cochonilhacarmim (Caccus cacti). Quando esta camada está seca e polida, são aplicadas várias demãos de tolte, outro mineral branco moído e misturado a corantes. Depois de secar por dois ou três dias, a peça é polida novamente com pedras de superfície lisa e uniforme que são transferidas nas famílias de artesãos, de geração em geração.

Para a decoração final é usada a técnica do rayado ou a do dourado. Na primeira, a base de cor é coberta com várias camadas do mesmo tipo, antes de serem decoradas com desenhos tradicionais usando-se pontas

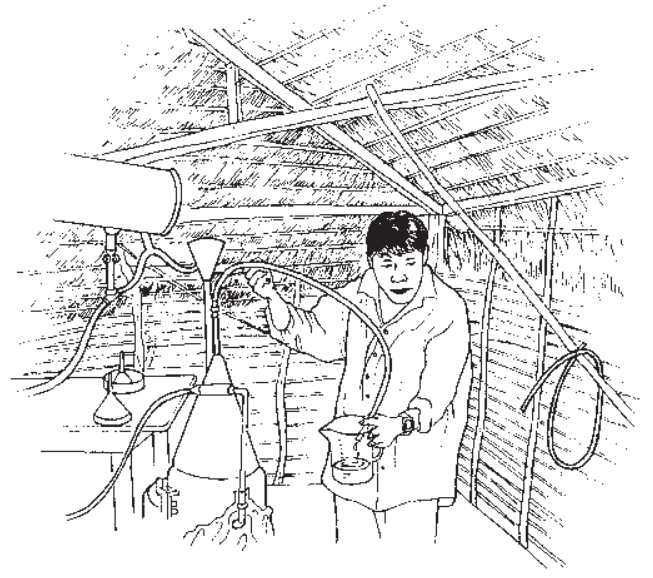

Atualmente, a destilaşão do óleo no México é feita somente por um pequeno número de produtores de Puebla e Guerrero, usando tecnologia muito rudimentar. de uma planta de babosa ou espinhos de acácia montados em penas de uma ave chamada guajolote. O rayado dá textura e cor às caixas. Por sua vez, a técnica do 'dorado' consiste em pintar desenhos - geralmente de animais ou de flores - com pincel de pelo de gato sobre a base de maque. Sem dúvida, ambos os processo têm raízes pré-hispânicas; têm sido encontrados vestígios muito antigos de rayado em xícaras. Mais tarde, as técnicas sofreram a influência estética européia e asiática durante a época colonial espanhola.

\section{Colhedores, artesãos e vendedores}

Hoje em dia, somente um pequeno número de pequenos produtores nos estados de Puebla e Guerrero destila o óleo essencial de linalol, que é vendido para os artesãos de Olinalá. A indústria de extração do óleo de linalol declinou dramaticamente desde a metade do último século. Os equipamentos e a tecnologia de destilação são muito rudimentares no México e implicam um alto custo energético e ambiental. O México não tem conseguido avanşos 


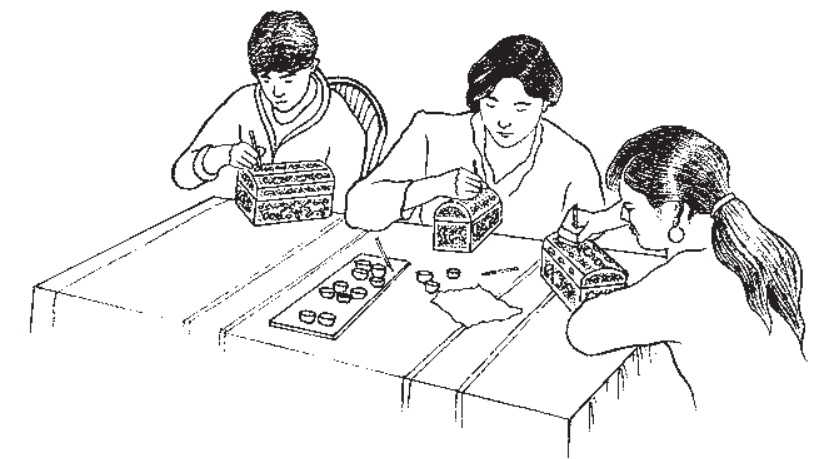

As mulheres preparam e aplicam as várias demãos de laca, dão polimento e retraçam os contornos dos desenhos. em relação à tecnologia utilizada nem no necessário suporte do governo e sequer no reconhecimento da importância dos produtos florestais não-madeireiros como é o caso do linalol. Por isso, não tem sido capaz de regularizar, atualizar, nem expandir o processo de destilaşão, o qual implica utilizar como matéria-prima o fruto ou a madeira calada produzidos a partir de plantasões ou da colheita sustentável*. Ainda persiste a derrubada ilegal para obter madeira calada para extrair o óleo, e como não tem sido incentivado nem o cultivo nem o replantio, e tampouco a proteção das plântulas* nos sistemas silvopastoris, as populações de plantas de linalol continuam declinando. Entretanto, estimuladas pela sua relevância, algumas comunidades de Guerrero, Morelos e Puebla iniciaram um processo de produção sustentável de óleo de linalol apoiado pelo Governo.

A maioria dos pequenos produtores que cortam linalol tem essa atividade como ocasional, e ela geralmente contribui com menos de 10 por cento da sua renda, mas é uma renda em dinheiro. Grande parte daqueles que abastecem a madeira são indígenas Nahua, enquanto os artesãos são principalmente mestizos*. A confecsão e comercialização do artesanato envolvem cerca de 600 famílias de forma permanente em Olinalá. Os seus produtos finais são vendidos em feiras regionais, mercados de produtos para turistas e centros urbanos, ou são exportados por intermediários para a Europa e Estados Unidos.

Os presos aumentam ao longo da cadeia de produção. A madeira de linalol é comprada por cerca de 9 dólares por seção de tronco de aproximadamente 60 centímetros de comprimento, suficiente para produzir três peças de tamanho médio. Os artesãos em Olinalá recebem cerca de 8 dólares por peça. Em uma feira regional, a mesma peça alcançaria o valor de 11 dólares, aumentando para 28 dólares nas cidades e até 37 dólares nos centros turísticos ou nos mercados de outros países.

\section{Para além do botânico, um potencial humano}

O grande potencial do artesanato de madeira e óleo essencial de linalol demanda uma oferta sustentável de matéria-prima legítima. Para assegurar a continuidade da habilidade dos artesãos e da qualidade dos seus produtos, é necessário resgatar o perfil original do artesanato, assim como a sua inovasaão. Além disso, é necessário conquistar novos mercados para o óleo de linalol e melhorar os processos para a sua obtenção. O linalol é parte do patrimônio cultural mexicano. Por isso, mais que os processos técnicos em si, são os campesinos e os artesãos envolvidos no seu aproveitamento quem devem ser reconhecidos e apoiados em seu trabalho com a espécie. Nesse sentido, o potencial dos produtos florestais não-madeireiros tem uma raiz social e cultural determinante: expressa e sintetiza os conjuntos de populaşões que têm desenvolvido esse potencial e para os quais há uma dívida. 


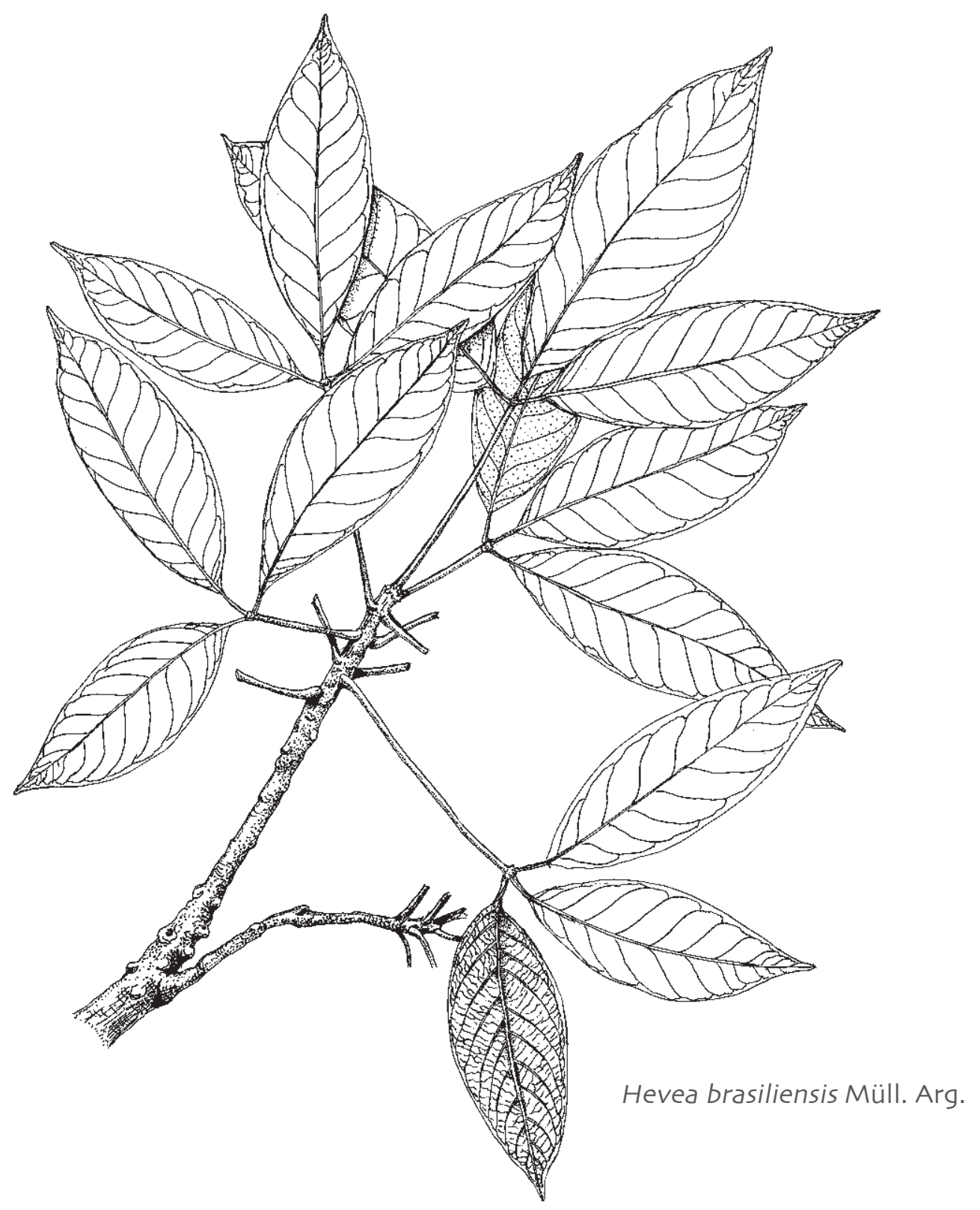

\section{Seringa, couro vegetal}

Caso brasileiro apresentado por Mariana Ciavatta Pantojaa 


\section{Couro vegetal: Do coração da amazônia ao mundo da moda}

Viaje durante horas de avião ou de ônibus. Em seguida, tome um barco rio acima. Finalmente, caminhe floresta adentro até que não possa dar mais um passo. Aí está você: no coracão da Amazônia brasileira, totalmente maravilhado pela exuberância e beleza da vegetação. Mas viver aqui não é fácil, como rapidamente descobriram os imigrantes que chegaram, ao final do século XIX. Longe de tudo que Ihes era familiar, se deram conta que para sobreviver teriam que recorrer ao que a mata Ihes oferecia. Assim, em meio a encontros e desencontros com os povos indígenas*, eles aprenderam muito sobre a mata e seus recursos: começaram a plantar e caçar, e viram-se obrigados a usar a imaginação para criar tudo o que necessitavam no seu dia-a-dia. Entre os muitos objetos que produziram, o saco encauchado passou a ser um dos mais importantes.

Com o tempo, o material utilizado para confeccionar estes sacos foi melhorando, convertendo-se no 'couro vegetal', como é hoje conhecido. Carteiras finas, vestido e muitos outros artigos vendidos em lojas famosas de vários países ao redor do mundo são manufaturados com esse material único que teve origem nessas remotas florestas.

\section{O "leite da mãe" sustenta as famílias}

A matéria-prima utilizada para produzir o couro vegetal é o látex* da árvore de seringa (Hevea brasiliensis), assim chamada no Brasil e conhecido nos países de língua hispânica como árvore de 'siringa', 'hule' ou 'caucho'. Por séculos, tais árvores foram o centro da vida na Amazônia. De fato, a colonizaşão comesou a se expandir com o início da sua extração comercial no fim do século XIX, transformando para sempre o perfil econômico, social e político da região. Em um determinado momento, o caucho passou a ser o produto de exportaça mais importante, mas à medida que o cultivo expandiu para outras partes do mundo e foram desenvolvidos substitutos sintéticos, a atenção em torno do caucho tradicional declinou, assim como a renda que gerava. Entretanto, nos últimos 10 anos têm sido criadas alternativas ao uso do látex através de produtos derivados do caucho, como é o caso do couro vegetal.

A Hevea brasiliensis cresce nas florestas amazônicas. No estado do Acre, a densidade* é de uma árvore por hectare. Os seringueiros chamam de 'leite' o látex branco que exsuda dessas árvores e com freqüência o comparam com admiração ao "leite da mãe que sustenta a família". Existem diferentes tipos de árvores e plantações de seringa fora da Amazônia, mas se considera que essa espécie em particular é a apropriada para a elaboração do couro vegetal. No Acre e no sul do

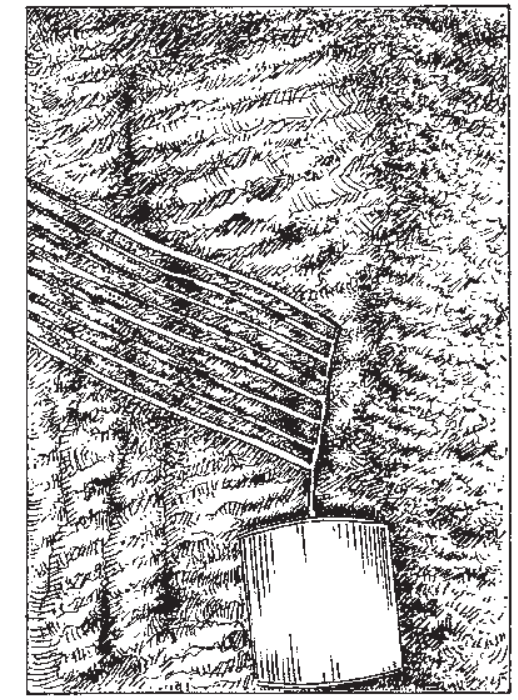

Os seringueiros dizem que o látex coletado das árvores é o "leite da mãe", que dá o sustento para as suas famílias. 
estado do Amazonas, existem cerca de 40 unidades de produção nas quais participam cerca de 70 famílias, beneficiando um total de 300 pessoas. Nas épocas de produção, todos os membros da família são envolvidos, especialmente os homens, às vezes com ajuda de vizinhos e parentes. As unidades de produção estão localizadas dentro de áreas de conservação florestal, como a Reserva Extrativista do Alto Juruá, a Floresta Nacional de Maipiá-Inauini e a Terra Indígena Kaxinawá do Rio Jordão.

\section{Da extração do látex à moda na Europa}

O primeiro passo na produção do couro vegetal é 'cortar uma estrada de seringa'. Quer dizer, extrair o látex de um grupo de árvores de seringa (cerca de 120) que crescem ao longo de um trecho de floresta. Com uma faca especial, o seringueiro "sangra" a árvore fazendo um corte no tronco. Cada corte produz somente uma pequena quantidade de látex, mas quando o seringueiro chega ao final da trilha, é muito provável que tenha conseguido coletar dez litros ou mais. O látex é misturado com um anticoagulante* para evitar seu espessamento. Depois, panos de algodão são impregnados com o látex, usando-se aproximadamente dois litros por peça, e em seguida são "curados" com a fumaşa vinda da chaminé de um forno em forma de vulcão. O calor e a fumaşa fixam o látex no tecido.

O tecido curado é colocado em um forno à lenha e 'assado', como dizem os seringueiros. Nesse processo, o tecido é "vulcanizado", ou seja, tratado com um composto de enxofre e aquecimento controlado à temperatura moderada, no qual é transformado em couro

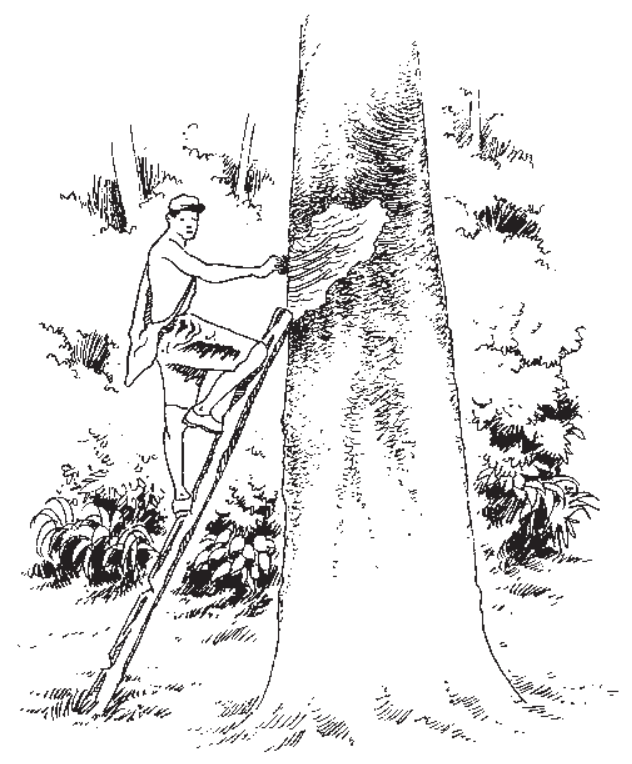

O seringueiro "sangra" tronco da árvore fazendo cortes com uma faca especial e coleta o látex que brota. vegetal. Essa etapa é importante porque ela determina a qualidade do produto. Se a vulcanização é feita sem cuidado, o couro não terá a consistência adequada e aparência pouco atrativa. Finalmente, cada peça é cortada em duas lâminas de couro vegetal e embalada para o seu transporte até o Rio de Janeiro.

A viagem se realiza em várias etapas: primeiro por rio até a cidade mais próxima, que no caso da Reserva Extrativista do Alto Juruá, pode demorar até três dias. Dali, o couro vegetal é despachado para a associação a que pertence o seringueiro, onde são feitos os arranjos necessários para o seu transporte até o destino final. Cada par de lâminas de couro vegetal é vendida pela associação por 8 reais (4 dólares). Essa quantia não inclui os gastos com materiais e transporte até o destino final, os quais são cobertos pela empresa compradora. A maior proporsão da renda, 3 reais (1,50 dólares), é paga ao produtor de látex. O látex utilizado para produzir o couro vegetal gera uma renda aos seringueiros praticamente cinco vezes maior que a venda de látex. Tanto é que a manufatura do couro vegetal tem ajudado a aumentar a renda de alguns seringueiros da Reserva Extrativista do Alto Juruá em praticamente 22 por cento e em outros lugares, como o Floresta Nacional Mapiá-Inauini, em mais de 50 por cento.

No Rio de Janeiro, as lâminas de couro vegetal recebem um último tratamento para aumentar a sua durabilidade e dar-lhes uma aparência brilhante. O preşo de cada lâmina depende da qualidade, do 
tamanho e de características especificadas por seus compradores. Hoje, uma lâmina custa aproximadamente 24 reais (12 dólares). A empresa Couro Vegetal da Amazônia, tradicional compradora do produto, exporta lâminas de primeira qualidade para a Europa, onde são vendidas por 25 a 55 reais ( 13 a 28 dólares) cada uma e transformadas em vestidos, carteiras, bolsas, agendas, pastas, calçado e muitos outros produtos.

\section{Motociclistas, ambientalistas e consumidores}

Durante a feira Flora, um evento dedicado à promoção de produtos amazônicos que acontece uma vez ao ano na cidade de Rio Branco, no estado do Acre, o estande do couro vegetal é um dos mais visitados. Embora o mercado de couro vegetal ainda tenha que ser consolidado, o produto já é muito bem recebido e tem conseguido atrair a atenção e apoio dos consumidores. Grupos de motociclistas, por exemplo, se mostram interessados em se tornarem "verdes", trocando alguns de seus produtos de couro por outros "mais voltados para a mata". As jovens que querem andar na moda adquirem carteiras e roupas, e as criancas compram suas mochilas escolares feitas de couro vegetal.

Em relação às exportaşões, novas possibilidades têm sido exploradas, especialmente no mundo da moda. Nos estados do Acre e do Amazonas, também se produz outro produto similar ao couro vegetal conhecido como 'couro ecológico'. A diferença em relação ao couro vegetal é que para produzir o couro ecológico são utilizados produtos químicos para fixar o látex ao tecido, em vez de submetê-lo ao processo de defumação. Com isso, não é necessário o corte de árvores para obtenção de lenha.

A pesar do êxito inicial do couro vegetal, ainda há algumas questões a serem resolvidas em relação à qualidade do produto. Outro desafio está relacionado ao estabelecimento de padrões técnicos, sociais e ambientais que garantam

o bem-estar dos seringueiros, assim como a sustentabilidade* do recurso natural. Com esse objetivo, na Floresta Nacional Mapiá-Inauini foram elaborados planos de manejo para árvores produtoras de seringa e lenha, que depois de submetidos ao Conselho de Manejo Florestal (FSC)* obtiveram a certificaşão florestal*, que garante o selo de origem* para o couro vegetal produzido. No há dúvida que os passos empreendidos pelos produtores constituem uma base sólida no sentido de assegurar a extração de látex social e ambientalmente sustentável.

Bolsas, mochilas, roupa e muitos outros produtos podem ser fabricados com o couro vegetal, muito em moda em várias cidades européias. 


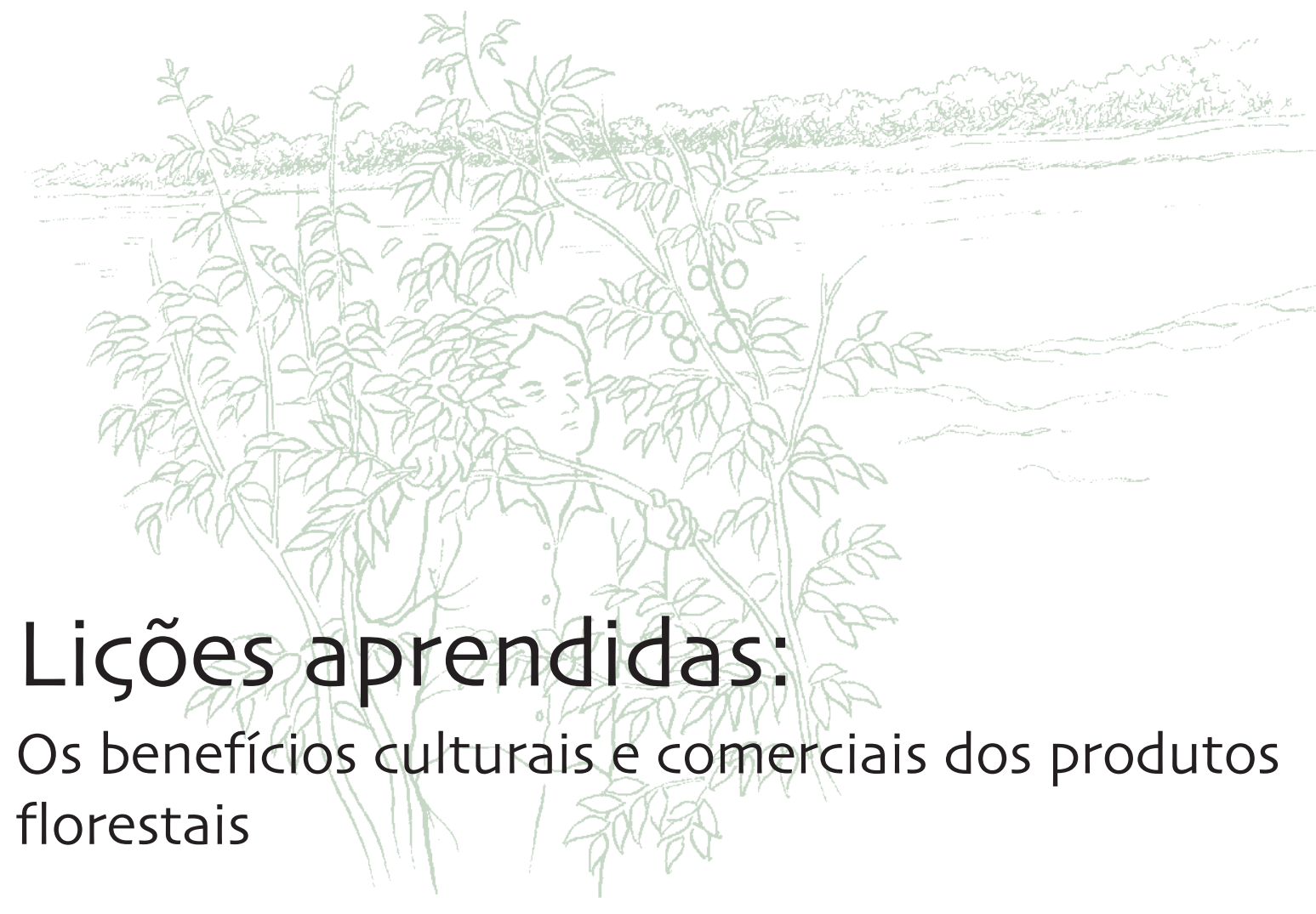

Os produtos florestais não-madeireiros (PFNMs) desempenharam um papel importantíssimo na forja da história da América Latina, particularmente das regiões de florestas tropicais. À medida que a cobertura florestal diminuia e um crescente número de habitantes da zona rural se mudava para as cidades, tornava-se cada vez mais importante para os coletores e consumidores de produtos florestais refletirem sobre o papel desses produtos nas suas vidas diárias. Um número estimado de 1,2 bilhões de pessoas ainda se vale da floresta e de seus arredores para encontrar comida, abrigo, remédios e utensílios para a sua sobrevivência diária (White et al. 2002). Alguns dos produtos florestais que eles coletam atingem os mercados de todo o mundo e são comercializados como pílulas energéticas, bebidas, temperos ou móveis de jardim. Nas cidades, uma rápida passada pelo posto de gasolina, supermercado ou shopping coloca a nossa disposição os produtos do dia-a-dia e os artigos de luxo. Mas os produtos da floresta que encontramos hoje nos mercados continuarão a existir amanhã?

Como mostram os casos apresentados neste volume, é difícil prever o futuro dos produtos florestais. Milhares desses produtos são comercializados em todo o mundo, incluindo uma grande variedade de plantas, fungos, insetos e carne de caça. Mas pouco se sabe sobre a sustentabilidade e o comércio mesmo daquelas espécies mais utilizadas. Isto é particularmente verdade para as espécies que têm vida longa e crescimento lento. Pouco também é conhecido sobre os muitos coletores de produtos florestais, que estão distantes das lojas e outros locais de venda onde os consumidores urbanos encontram seus artigos desejados. 
Os casos apresentados neste volume mostram a grande diversidade da coleta, manejo e comercialização, mas também surpreendentes similaridades entre eles. Através da comparação entre os casos nós podemos ter um melhor entendimento das características do manejo de recursos naturais em pequena escala e do contexto sócio-econômico mais amplo do uso de recursos florestais na América Latina.

\section{Diversidade de usos}

Os casos apresentados neste livro ilustram como os produtos florestais são usados diretamente para subsistência, como as frutas tropicais e plantas medicinais, até os usos de luxo como os chapéus panamá e os bordados com fibra de pita. Mostram também como uma única planta pode ter uma infinidade de usos. O babasu é um exemplo excepcional, com seus frutos, tronco e folhas usados para como combustível, brinquedos, telhado de casas, óleo e sabão. A madeira da andiroba, uma árvore também para múltiplos usos, serve como material de construção, enquanto o seu óleo é usado como repelente de insetos e no tratamento da artrite e da irritação da pele, além de combater verminoses. Diferentes partes da palmeira pupunha são usadas para construir pontes e casas e para confeccionar utensílios e bijuterias, além de produzir tira-gostos, bebidas, farinha e bolos. Quando existe tal variedade de usos para uma única espécie, a diminuição das suas populaşões ou a perda de seu material genético pode ter múltiplas conseqüências para a saúde e bem-estar das famílias que dependem dos recursos ou dos produtos prontos da floresta.

Usos para subsistência (alimentos, remédios, matérias-primas para utensílios domésticos e para a agricultura, material de construcãa, etc.)
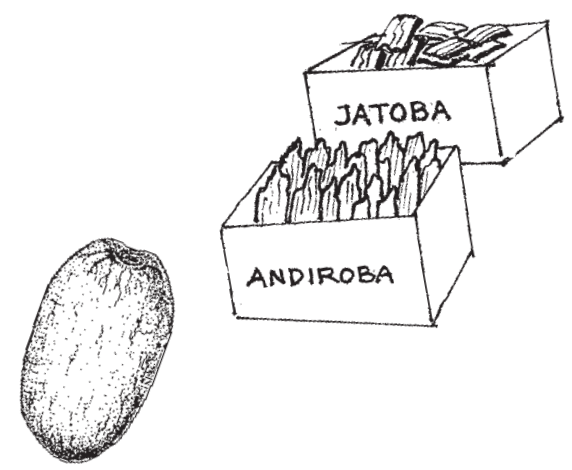

Usos comerciais (alimentos exóticos, remédios, matéria-prima para artesanato, componentes de produtos industriais, etc.)
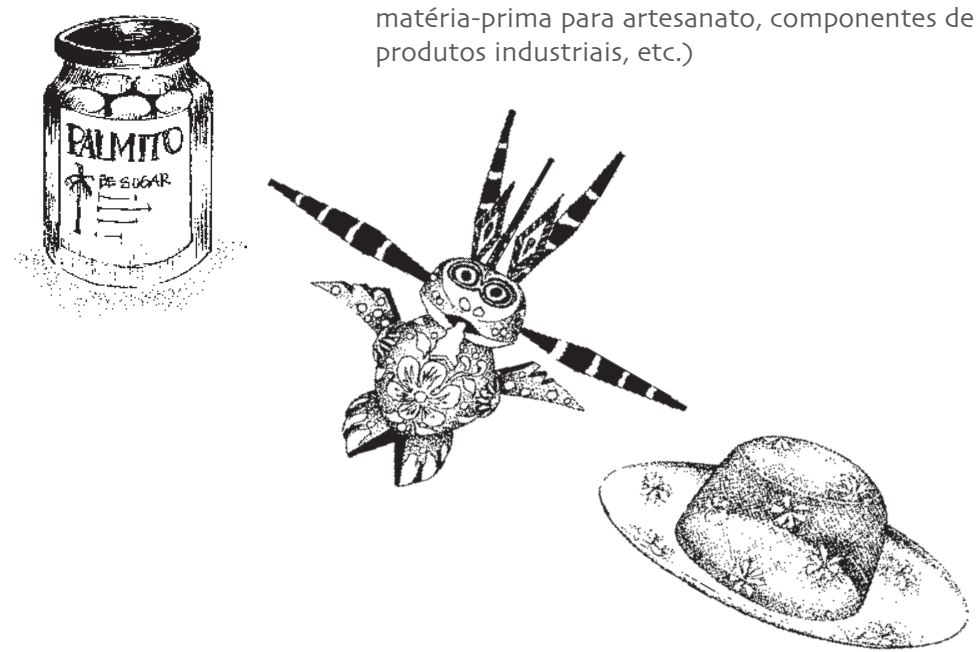

Os produtos florestais são usados tanto para suprir as necessidades de subsistência como para gerar renda 
Os produtos florestais não-madeireiros também desempenham um papel crítico na identidade local, mitos e práticas espirituais. Mesmo quando as políticas nacionais ou internacionais indicam que a colheita e o manejo de alguns produtos florestais são anti-econômicos, famílias podem persistir na atividade de coleta - geralmente tendo as árvores como uma espécie de poupança. Ainda que práticas locais possam parecer inviáveis aos olhos de pessoas de fora da comunidade, os laços culturais com a terra e com os sistemas de manejo determinam a sobrevivência dessas práticas.

\section{Diversidade de práticas de manejo}

Para se protegerem das flutuasões na oferta e demanda, muitas famílias rurais coletam e manejam vários recursos e mantêm um mosaico de usos da terra, incluindo roças, quintais, campos e florestas de diferentes idades misturadas na paisagem. O manejo de diferentes recursos e usos da terra geralmente é o resultado de séculos de experiência e conhecimento bem como de contínua inovação pelos agricultores. Em um dos extremos do gradiente de manejo estão as plantas cultivadas, como a ipeca e as plantasões de pinheiros para a coleta de resina. No outro extremo estão os recursos que são extraídos das florestas com pouco ou nenhum manejo, como a madeira para esculpir os alebrijes e a borracha (Quadro 2).
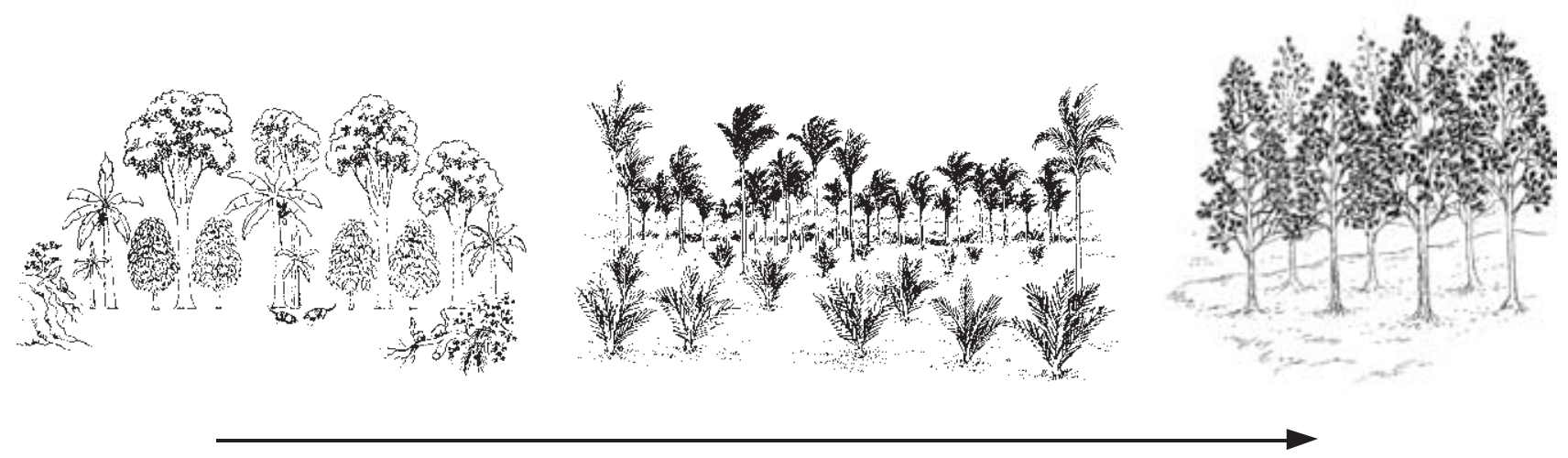

Em ordem crescente de intensidade de manejo do recurso

O manejo de muitos PFNMs situa-se entre a extração direta da floresta e o cultivo. Eles são moderadamente manejados nas áreas florestais, como a pimenta-da-jamaica e as árvores para produzir o papel amate que crescem nas plantações de café sombreado, e as palmeiras babaçu e xa'an nos campos agrícolas. Tolerar certas plantas dentro das lavouras e pastagens, lançar sementes comestíveis ao longo de trilhas e fazer uma cobertura morta em torno de árvores frutíferas no quintal são algumas das práticas realizadas para garantir que as espécies favorecidas regenerem nas 


\begin{tabular}{|c|c|}
\hline Manejo & Produto/Espécie \\
\hline Coletadas de populaşões silvestres, sem manejo & $\begin{array}{l}\text { folhas de camedor (Chamaedorea elegans) } \\
\text { fibra de pita (Achmea magdalenae) } \\
\text { látex (Hevea brasiliensis) } \\
\text { palmito (Euterpe edulis) }\end{array}$ \\
\hline $\begin{array}{l}\text { Estimuladas, protegidas ou manejadas em } \\
\text { florestas naturais }\end{array}$ & uxi (Endopleura uchi) \\
\hline $\begin{array}{l}\text { Manejadas juntamente com outras espécies } \\
\text { nativas úteis na vegetação natural }\end{array}$ & $\begin{array}{l}\text { gingseng brasileiro (Pfaffia glomerata) } \\
\text { bacuri (Platonia insignis) } \\
\text { carqueja (Baccharis trimera) } \\
\text { espinheira-santa (Maytenus ilicifolia) }\end{array}$ \\
\hline $\begin{array}{l}\text { Toleradas em campos agrícolas (não eliminadas, } \\
\text { permitindo-se que creş̧am naturalmente) }\end{array}$ & $\begin{array}{l}\text { pimenta-da-jamaica (Pimenta dioica) } \\
\text { papel amate (Trema micrantha) } \\
\text { babasu (Orbignya phalerata) } \\
\text { palmeira xa'an (Sabal yapa) }\end{array}$ \\
\hline $\begin{array}{l}\text { Cultivadas em florestas naturais } \\
\text { Cultivadas em campos agrícolas em combinaşão } \\
\text { com outras espécies }\end{array}$ & $\begin{array}{l}\text { ipeca (Psychotria ipecacuanha) } \\
\text { pupunha (Bactris gasipaes) }\end{array}$ \\
\hline Cultivadas em plantasões monoculturais & resina de pínus (Pinus caribeae) \\
\hline
\end{tabular}

proximidades das casas. Para satisfazer as preferências dos consumidores e produzir suficiente carne para atender à demanda do mercado, os agricultores podem não somente intensificar o manejo, mas também modificar as características de certas espécies. Por exemplo, durante séculos os indígenas da América Latina selecionaram frutas que tinham uma maior percentagem de polpa e favoreceram palmeiras sem espinhos, como no caso da pupunha. A próxima tabela indica a amplitude da intensidade com que algumas espécies apresentadas neste volume são manejadas.

O gradiente de práticas de manejo descritas se reflete no grau de dependência dos recursos da floresta. Algumas famílias dependem quase que completamente dos recursos silvestres, enquanto outras diversificam suas atividades, incluindo a coleta e a venda de vários produtos florestais. Tanto homens quanto mulheres colhem produtos florestais, embora os homens dominem a colheita de certos produtos, como as folhas da palmeira camedor, palmito, fibra pita e látex, enquanto as mulheres têm um papel muito importante no processamento dos produtos, como as esculturas alebrijes, papel amate e folhas medicinais de carqueja.

\section{O valor dos PFNMs para diversos setores da sociedade}

Estimativas de que 80 por cento da população mundial usem recursos da floresta para suprir suas necessidade de cuidado com a saúde (Farnsworth et al. 1985) indicam a importância crítica desses recursos para a subsistência e uso direto. Os produtos da floresta também ajudam a muitos a sobreviverem às dificuldades sazonais e a resistirem durante os períodos de guerra. Em muitos 
casos, os recursos da floresta provêem uma renda suplementar àquela gerada pela agricultura ou outras fontes. Por exemplo, a colheita de bacuri, mamey e uxi podem ser escalonadas com outras demandas por mão-de-obra e época de frutificaşão. Os casos do babaçu, camu-camu e palmito mostram que mesmo quando os colhedores recebem relativamente pouco, os podem representar a sua fonte de renda em dinheiro mais importante. As famílias rurais podem usar a renda gerada pela venda de matéria-prima ou produtos para cobrir importantes gastos como as despesas escolares ou tratamentos médicos.

O comércio de PFNMs é feito em mercados locais, regionais ou internacionais. Muito do comércio local e regional de recursos florestais ocorre durante a escuridão da madrugada em barcos, ao longo de rios e em ruelas dos mercados de rua da periferia. Os mercados locais oferecem às populações rurais e urbanas oportunidades de venda que são mais acessíveis, estáveis e mais fáceis de negociar e menos arriscados que o comércio internacional. Esse imenso canal de comércio informal, entretanto, não é contabilizado nas estatísticas nacionais.

Estatísticas sobre a exportação de PFNMs existem, mas geralmente subestimam os volumes e incluem somente alguns produtos muito valiosos como o palmito. A despeito da falta de pesquisas sobre o comércio de PFNMs em todos os níveis, as estatísticas disponíveis indicam um crescimento do comércio global. Essa tendência é particularmente notável na comercialização de produtos de plantas medicinais, que está crescendo vertiginosamente. Em 1999 o comércio de fitoterápicos e ervas alcansou a cifra de 20 bilhões de dólares (Gruenwald 2000).

Na América Latina, as condições atuais que favorecem o comércio de PFNMs incluem o rápido crescimento das populasões urbanas, o crescimento do acesso aos mercados e o incremento do turismo. Alguns produtos que eram usados para consumo doméstico em áreas rurais, recentemente passaram a ser mais amplamente comercializados. Antes usadas para construir os telhados das casas Maias, as folhas da palmeira xa'an tornaram-se usadas comercialmente como materiais de construção, para dar uma aparência rústica aos hotéis turísticos do Caribe Mexicano. O papel amate, no passado usado para fins cerimoniais no México, é agora vendido como souvenir. A borracha da Amazônia é agora processada para criar bolsas caras, encontradas em lojas da moda de Paris e Nova lorque.

\section{Respostas à crescente demanda}

Como os coletores respondem ao crescimento das oportunidades de mercado? Os exemplos neste volume mostram que quando a espécie alvo se torna escassa os coletores usam várias estratégias para atender à crescente demanda. Em alguns casos eles passam a procurá-la em locais mais distantes, caminhando distâncias cada vez maiores para encontrarem os recursos (alebrijes, ginseng brasileiro, linalol). No caso do palmito, na Mata Atlântica brasileira, a superexploração de plantas silvestres levou à sua extinção em muitos locais. Em outros casos, os coletores procuram por plantas ou animais que possam substituir os recursos originais. Com o desaparecimento do palmiteiro (Euterpe edulis), originalmente usado para extrair o palmito na Mata Atlântica, outras espécies de palmeira (Euterpe oleracea e Bactris gasipaes) estão sendo usadas como novas fontes de matéria-prima. Nas últimas três décadas no México, os artesãos que produzem papel amate e caixas de linalol substituíram as suas espécies de árvores preferidas, Ficus e Bursera spp., respectivamente, por outras espécies. Para aumentar o peso e o volume, coletores podem ludibriar compradores inexperientes substituindo a casca e as folhas de espécies raras por espécies mais comuns, como no caso da espinheira-santa. 
Outra resposta ao aumento da escassez é a intensificação do manejo da espécie. Na Ásia, séculos de comércio levaram ao aumento do manejo de muitos recursos da floresta comumente comercializados, incluindo o bambu, o cardamomo e o ratan. Na África e na América Latina, muitos dos produtos mais comercializados da floresta ainda não são intensivamente manejados ou cultivados, mas ainda retirados das florestas. O cultivo é uma opsão mais viável para as espécies herbáceas e arbustivas de crescimento rápido do que para as árvores de crescimento lento. Os produtos da América Latina ilustram os vários graus de intensificação do manejo de algumas espécies, como o uxi, que passa por um processo de intensificaşão experimental pelos agricultores. A despeito das tentativas de cultivo, 15 dos 24 produtos pesquisados pelos colaboradores do CIFOR continuam a ser coletados de populaşões naturais de espécies não domesticadas, indicando que o extrativismo ainda é um importante modelo de produção na América Latina.

\section{Efeitos do comércio}

Ao contrário do que muitos consumidores podem pensar, a crescente demanda por produtos florestais nem sempre resulta em melhor renda para os coletores, processadores ou comerciantes rurais. Muitos recursos florestais são subvalorizados e os presos que os produtores recebem é extremamente baixo, mal compensando os seus custos de produção.

O aumento da demanda e do lucro da comercialização pode ter os seguintes efeitos:

- Redução do suprimento e do acesso aos recursos da floresta pelas famílias que dependem dos produtos florestais para seu próprio uso;

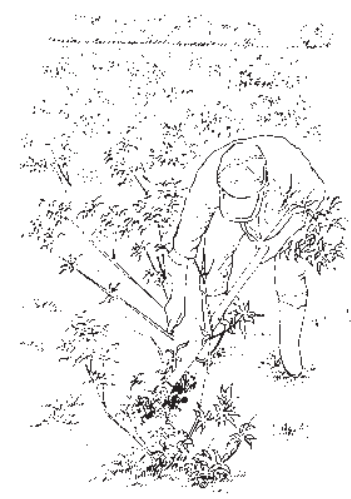

Pressão sobre os recursos Técnicas de colheita Manejo do recurso

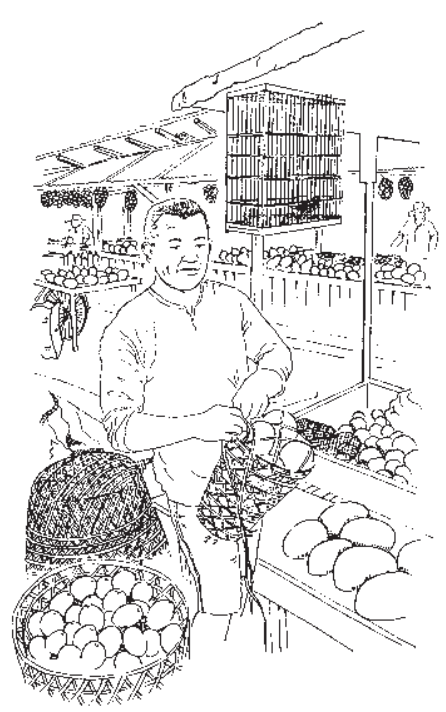

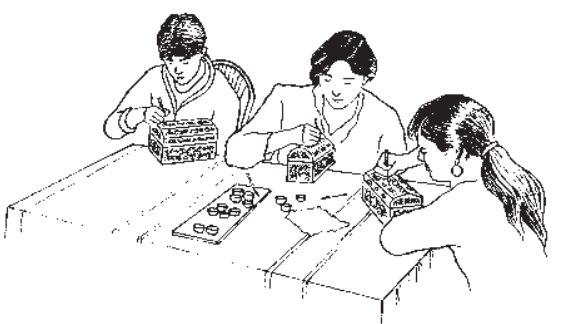

Mudanças na tecnologia de processamento

Divisão do trabalho

Qualidade e quantidade da produção

Transporte e comercializaşão

Quando a demanda por uma a produto florestal aumenta, muitas mudanças podem ocorrer em relação à colheita, processamento e comercialização 
- Diminuição do acesso às terras com florestas ou a recursos específicos da floresta pelos pequenos agricultores que não têm a propriedade da terra ou condições financeiras para realizarem investimentos;

- Favorecimento de práticas de manejo novas e mais intensas que tendem a envolver um novo grupo de agricultores com melhor acesso a terra e tecnologias, expulsando, portanto, os usuários originais;

- Aumento na divisão de tarefas e possível abandono das técnicas tradicionais de colheita e processamento.

Por outro lado, o aumento do comércio também tem resultado em benefícios como:

- Maior renda para algumas famílias rurais e urbanas;

- Melhoria na educação e saúde;

- Aumento do orgulho cultural e auto-estima;

- Ampliasão das opsões econômicas, que podem permitir às famílias permanecerem nas áreas rurais.

\section{O que sabemos sobre os produtos florestais não-madeireiros}

Os estudos de caso apresentados neste livro demonstram que os produtos florestais são importantes pelo seu papel na subsistência, comércio e sentimento de lugar e identidade cultural que eles oferecem as centenas de milhões de famílias rurais e urbanas em todo o mundo. A possibilidade de um recurso florestal continuar a satisfazer essas necessidades, entretanto, depende da colheita sustentável e das práticas de manejo a ele aplicadas.

Por causa da complexidade e das conseqüências potencialmente negativas do aumento do comércio de produtos florestais pelos pequenos agricultores, planos para aumentar a comercialização ou para intensificar a sua produção devem levar em conta a grande gama de impactos potenciais. Os produtos florestais são geralmente colhidos de maneira não sustentável e seu valor raramente é apropriado de maneira eqüitativa por todas as pessoas envolvidas na sua coleta, processamento e comércio.

O acesso à informação sobre o manejo, uso e comercialização de produtos florestais é uma parte importante das campanhas de conscientização e pode ajudar a garantir o futuro tanto dos produtos florestais como dos povos que deles dependem. Em nível internacional, muito ainda há que ser feito para promover o sinergismo entre as organizações dentro e fora do setor florestal e para melhorar a capacidade das organizações nacionais para incluírem a contribuição multidimensional das florestas nos seus programas de pesquisa e desenvolvimento. A complexidade dos PFNMs implica a dificuldade para se fazer generalizacõoes sobre eles. Entretanto, com base nos casos da América Latina apresentados neste volume, algumas observasões podem ser feitas:

\section{Comércio}

- O interesse global nos produtos florestais tem flutuado desde a era colonial, com alguns produtos perdendo importância (barbasco, chicle, borracha) e outros ganhando importância (artesanato, frutas, plantas medicinais). Os europeus descobriram o Novo Mundo por causa do seu grande 
interesse na busca e no domínio do comércio dos produtos florestais tais como as especiarias e os condimentos.

- Ciclos de auge e declínio são característicos para alguns PFNMs comercializados internacionalmente (barbasco, chicle, borracha). Os produtos florestais com grande volume exportado são geralmente superexplorados, levando à sua substituição por produtos similares naturais ou industriais ou substituídos pelo cultivo. Este não é o caso da maioria dos produtos comercializados local e regionalmente, que tendem a ter uma oferta e uma demanda mais estáveis e continuam a ser extraído diretamente da natureza.

- O interesse global nas ervas e produtos florestais está aumentando e a expectativa é de que continue a aumentar ao longo do século XXI. Poucos produtos têm sido adequadamente estudados e muitos deles podem ser ameaçados pela perda do seu habitat.

- Os efeitos potenciais da comercialização deveriam ser previstos antes de se promover o comércio dos produtos florestais. Entre outros grandes problemas, o aumento da demanda pode marginalizar os que já têm menor poder - mulheres, crianças e idosos - que podem receber poucos benefícios ou mesmo perder o acesso aos recursos da floresta.

\section{Cultura e subsistência}

- Troca de conhecimento. O comércio de produtos florestais na América Latina envolveu séculos de trocas de experiências e conhecimento em relação ao seu processamento e manejo.

- Valores não-comerciais são críticos, particularmente para a saúde e bem-estar das populacões rurais e urbanas pobres, mas os governos, organizações de pesquisa e doadores frequentemente se esquecem dessas necessidades.

- Usos culturais de recursos florestais têm um papel proeminente na vida das pessoas de todas as classes tanto em ambientes rurais quanto urbanos. Quando os recursos ganham valor, eles são geralmente apropriados por interesses mais poderosos. Valores culturais associados aos produtos florestais são geralmente forças motrizes para o seu uso e manejo e merecem muito maior atenção.

\section{Ecologia}

- A principal ameaça à maioria dos PFNMs da América Latina estudados não é a superexploração pelos coletores mas o desmatamento (expansão agrícola, extraşão da madeira, mineração, criação de gado).

- As inovaç̃̃es no manejo dos recursos forjadas localmente são geralmente o resultado de experimentasão de longo prazo pelas populasões rurais e poderiam desempenhar um papel central na oferta sustentável, uso e comércio de produtos florestais.

- A falta de conhecimento sobre a ecologia, uso, comércio e valoração dos PFNMs pode coibir a sua inclusão significativa no manejo da floresta, redução da pobreza e programas relacionados. 


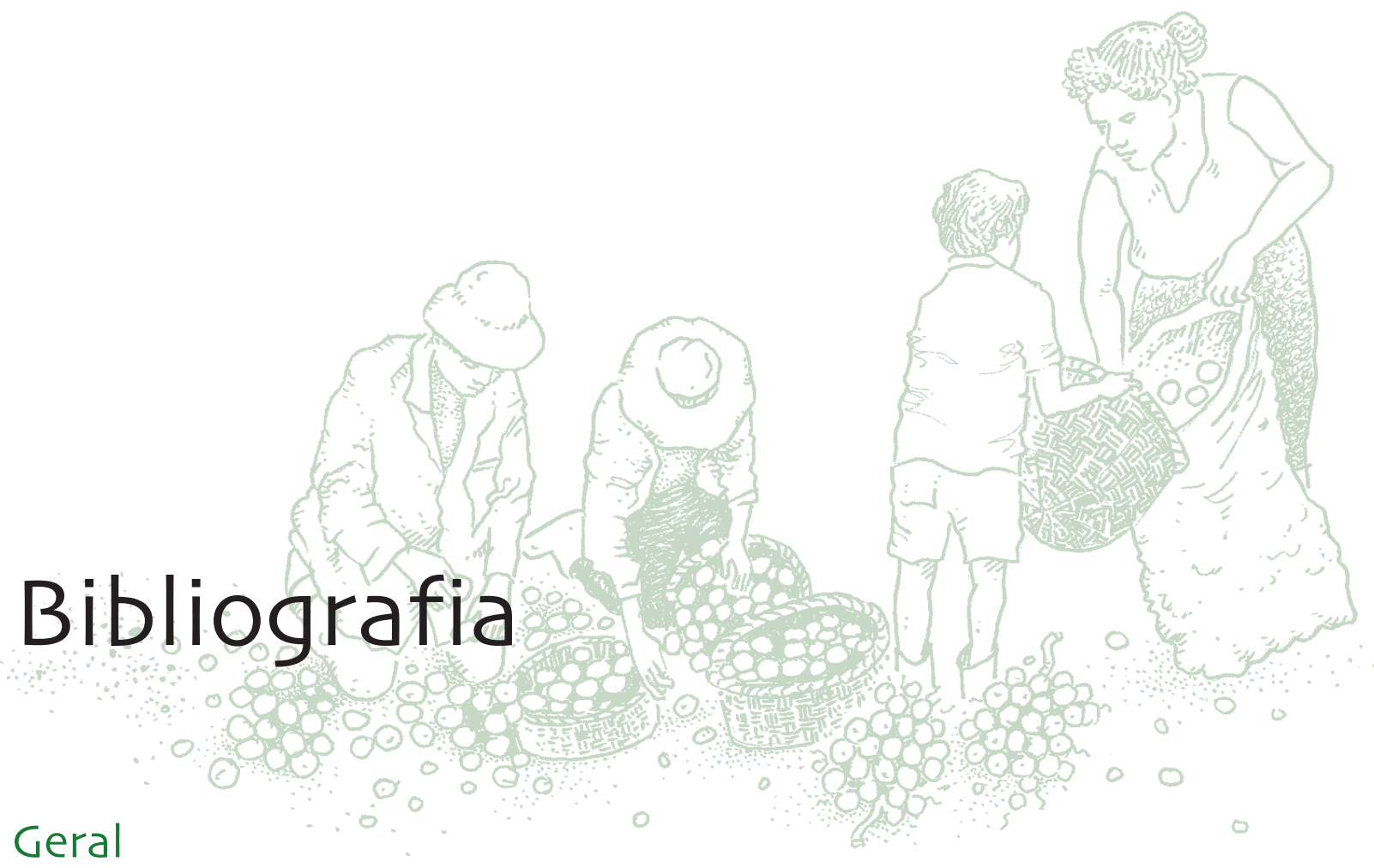

Alexiades, M. N. e Shanley, P. 2004 Productos forestales, medios de subsistencia y conservación: Estudios de caso sobre sistemas de manejo de productos forestales no maderables.

Balée, W. 1994 Footprints of the forest: Ka'apor ethnobotany. The historical ecology of plant utilization by an Amazonian people. Columbia University Press, New York.

Bennett, B.C. 1992 Plants and people of the Amazonian rainforests: The role of ethnobotany in sustainable development. Bioscience 42: 599-607.

Campbell, B.M. e Luckert, M. (eds.) 2002 Uncovering the hidden harvest: Valuation methods for woodland and forest resources. People and Plants Conservation Series. Earthscan, UK and USA. $262 p$.

Cunningham, A.B. 2001 Applied Ethnobotany: People, plant use and conservation. People and Plants Conservation Manuals. Earthscan, UK and USA. 300p.

Duke, J.A. e Vasquez, R. 1994 Amazonian ethnobotanical dictionary. CRC Press, USA. 215P.

Farnsworth, N.R., Akerele, O., Bingel, A.S., Soejarto, D.D e Guo, Z. 1985 Medicinal plants in therapy. Bulletin of the World Health Organization $63(6)>965: 981$. 
Heywood, V.H. 1978 Flowering plants of the world. Oxford University Press, Oxford, UK.

Laird, S. (ed.) 2002 Biodiversity and traditional knowledge: Equitable partnerships in practice. People and Plants Conservation Series. Earthscan, UK and USA. 504P.

Langman, I. 1964 A selected guide to the literature on the flowering plants in Mexico. The University of Pennsylvania Press, Philadelphia, PA., USA.

Pennington, T.D. y Sarukhán, J. 1998 Árboles tropicales de México. Manual para la identificación de las principales especies. Universidad Nacional Autónoma de México (UNAM)/Fondo de Cultura Económica (FCE), México.

Pio Corrêa, M. 1984 Dicionário das plantas úteis do Brasil. Distrito Federal, Ministério da Agricultura, Instituto Brasileiro de Desenvolvimento Florestal (IBDF).

Ruiz-Pérez, M. e Byron, N. (eds.) 1999 A methodology to analyze divergent case studies of nontimber forest products and their development potential. Forest Science 45(1): 1-14.

Shanley, P. e Medina, G. (eds.) (in press) Frutíferas e plantas úteis na vida Amazônica. CIFOR e Instituto do Homem e Meio Ambiente da Amazônia (IMAZON). 278p.

Shanley, P., Pierce, A.R., Laird, S. e Guillén, A. (eds.) 2002 Tapping the green market: Certification and management of non-timber forest products. People and Plants Conservation Series. Earthscan, UK and USA. 456P.

White, A. e Martin, A. 2002. Who owns the world's forests? Forest tenure and public forests in transition. Forest Trends/Center for Internacional Environmental Law. 30p.

\section{Frutas}

Balick, M.J. e Pinheiro, C.U.B. 1993 Babassu. In: Clay, J.W. e Clement, C.R. (eds.) Selected species and strategies to enhance income generation from Amazonian forests. Food and Agricultural Organization of the United Nations (FAO), Italy, Rome.

Cavalcante, P.B. 1991 Frutas comestíveis da Amazônia. Edições Cejup, Belém, Pará. 279p.

Clement, C.R. e van Leeuwen, J. 2004 Sub-utilização da pupunha (Bactris gasipaes Kunth) na Amazônia Central: História, cadeia de produsão, e implicasões para o desenvolvimento e conservaşão. In: Alexiades, M.N. y Shanley, P. (eds.) 2004 Productos forestales, medios de subsistencia y 
conservación: Estudios de caso sobre sistemas de manejo de productos forestales no maderables. Volumen 3 - América Latina. Centro para la Investigación Forestal Internacional (CIFOR), Bogor, Indonesia.

May, P.H. 1990 Palmeiras em chamas: Transformação agrária e justiça social na zona de babaşu. Empresa Maranhense de Pesquisa Agropecáuria (EMAPA), Finaciadora de Estudios e Projetos (FINEP) e Fundação Ford. São Luís, Maranhão, Brasil.

Medina, G. e Ferreira, S. 2004 Bacuri (Platonia insignis Martius): O fruto Amazônico que virou ouro. In: Alexiades, M.N. y Shanley, P. (eds.) 2004 Productos forestales, medios de subsistencia y conservación: Estudios de caso sobre sistemas de manejo de productos forestales no maderables. Volumen 3 - América Latina. Centro para la Investigación Forestal Internacional (CIFOR), Bogor, Indonesia.

Ministério da Indústria e Comércio/Secretaria de Tecnologia Industrial (MIC/STI) 1982 Mapeamento do potencial das ocorrências de babaçuais. Estado do Maranhão, Piauí e Goiás. Brasília, Brasil.

Mora-Urpí, J., Weberand, J.C. e Clement, C.R. 1997 Peach palm Bactris gasipaes Kunth. Promoting the conservation and use of underutilized and neglected crops. Publication No. 20. International Plant Genetic Resources Institute (IPGRI)/Institute of Plant Genetics and Crop Plant Research (IPK), Rome, Italy. 83p. (http://www.ipgri.cgiar.org/publications/pdf/155.pdf)

Morten, B.H. 2001 The natural extraction of the native fruit from Myrciaria dubia (camu camu) e its potential for cultivation in the Peruvian Amazon. The Royal Veterinary and Agricultural University, Copenhagen, Denmark. 59p.

Morton, J.F. 1987 Fruits of warm climates. Published by Julia F. Morton, Miami, USA.

Nava-Cruz, Y. y Ricker, M. 2004 El Zapote Mamey (Pouteria sapota (Jacq.) H. Moore y Stearn), un fruto de la selva Mexicana con alto valor comercial. In: Alexiades, M.N. y Shanley, P. (eds.) 2004 Productos forestales, medios de subsistencia y conservación: Estudios de caso sobre sistemas de manejo de productos forestales no maderables. Volumen 3 - América Latina. Centro para la Investigación Forestal Internacional (CIFOR), Bogor, Indonesia.

Oyen, L.P.A. 1991 Pouteria sapota (Jack) H.E. Moore \& Stearn. In: Verheij, E.W.M. y Coronel, R.E. (eds.) Plant resources of South-East Asia 2: Edible fruits and nuts, P. 259-262. Pudoc Scientific Publishers-DLO, Wageningen, The Netherlands.

Pennington, T.D. 1990 Flora Neotropica Monograph 52: Sapotaceae. The New York Botanical Garden, New York, USA. 
Peters, C.H.M. y Vásquez, M.A. 1987 Estudios ecológicos de camu-camu (Myrciaria dubia). Producción de frutos en poblaciones naturales. Acta Amazónica, Manaus, Brasil (16/17): 161-173.

Pinedo, P.M. 2002 Variación del contenido de vitamina C de camu-camu silvestre en Loreto, Perú. Instituto de Investigaciones de la Amazonía Peruana. Programa de Ecosistemas Terrestres. 7p.

Pinedo, P.M. y de Jong, W. 2004 Camu-camu (Myrciaria dubia McVaugh (H.B.K)) un arbusto Amazónico de áreas inundables con alto contenido de vitamina ( en Loreto, Perú. In: Alexiades, M.N. y Shanley, P. (eds.) 2004 Productos forestales, medios de subsistencia y conservación: Estudios de caso sobre sistemas de manejo de productos forestales no maderables. Volumen 3 - América Latina. Centro para la Investigación Forestal Internacional (CIFOR), Bogor, Indonesia.

Pinheiro, C.U.B. 2004 A palmeira babaçu (Orbignya phalerata Martius) e sua exploração na região dos cocais, Maranhão, nordeste do Brasil. In: Alexiades, M.N. y Shanley, P. (eds.) 2004 Productos forestales, medios de subsistencia y conservación: Estudios de caso sobre sistemas de manejo de productos forestales no maderables. Volumen 3 - América Latina. Centro para la Investigación Forestal Internacional (CIFOR), Bogor, Indonesia.

Pinheiro, C.U.B. e Frazão, J.M.F. 1995 Integral processing of babassu palm (Orbignya phalerata, Arecaceae) fruits: Village level production in Maranhão, Brazil. Economic Botany 49(1): 31-39.

Ricker, M., Mendelsohn, R.O., Daly, D.C. e Angeles, G. 1999 Enriching the rainforest with native fruit trees: An ecological and economic analysis in Los Tuxtlas (Veracruz, Mexico). Ecological Economics 31: $439-448$.

Ricker, M., Siebe, C., Sanchez, S.B., Shimada, K., Larson, B.C., Martinez-Ramos, M. e Montagnini, F. 2000 Optimizing seedling management. Pouteria sapota, Diospyros digna and Cedrela odorata in Mexican rainforest. Forest Ecology and Management 139: 63-77.

Shanley, P. e Gaia, G. A fruta do pobre se torna lucrativa: A Endopleura uchi Cuatrec. em áreas manejadas próximo a Belém, Brasil. In: Alexiades, M.N. y Shanley, P. (eds.) 2004 Productos forestales, medios de subsistencia y conservación: Estudios de caso sobre sistemas de manejo de productos forestales no maderables. Volumen 3 - América Latina. Centro para la Investigación Forestal Internacional (CIFOR), Bogor, Indonesia.

Weiss, D.K. 1998 Un estudio del mercado mundial para el camu-camu. Winrock International. Proyecto de Desarrollo Alternativo USAID/CONTRADROGAS. Convenio United States Agency for International Development USAID-Instituto Nacional de Desarrollo (INADE). 18p. 


\section{Folhas}

Aguilar de Tamariz, M. 1988 Tejiendo la vida. Las artesanías de la paja toquilla en el Ecuador. Centro Interamericano de Artesanías y Artes Populares (CIDAP), P 4, 22, 23 y 27.

Ahmed, M.S., Fong, H.H.S., Soejarto, D.D., Dobberstein, R.H. e Waller, D.P. 1981 High-performance liquid chromatographic separation and quantitation of maytansinoids in Maytenus ilicifolia. Journal of Chromatography 213: 340-344.

Alarcón, R. y Burbano, M.F. 2004 Uso de la paja toquilla (Carludovica palmata Ruiz \& Pavón), en la elaboración de sombreros en tres comunidades de la provincia de Manabí, Ecuador. In: Alexiades, M.N. y Shanley, P. (eds.) 2004 Productos forestales, medios de subsistencia y conservación: Estudios de caso sobre sistemas de manejo de productos forestales no maderables. Volumen 3 - América Latina. Centro para la Investigación Forestal Internacional (CIFOR), Bogor, Indonesia.

Alarcón, R. y Londoño, T. 1997 Manejo en vivero de la paja toquilla, Carludovica palmata (R\&P), en la zona de influencia del Parque Nacional Yasuní. In: Mena, P.A., Soldi, A., Alarcón, R., Chiriboga, C. y Suárez, L. (eds.) 1997 Estudios Biológicos para la Conservación, Diversidad, Ecología y Etnobiología, EcoCiencia, Quito, Ecuador, p. 376-381.

Araujo, J.E. da S. e Lucas, V. 1930 Catálogo de extractos fluidos dos Laboratórios Silva Araujo, Rio de Janeiro. Silva Araujo \& Cia Ltda 185: +XXIX.

Bennet, B., Alarcón, R. e Cerón, C. 1992 The ethnobotany of Carludovica palmata (Ruiz \& Pavón) (Cyclanthaceae) in Amazonian Ecuador. Economic Botany 46: 233-240.

Bernardi, H.H. e Wasicky, M. 1959 Algumas pesquisas sobre a "Espinheira Santa" ou "Cancerosa" Maytenus ilicifolia, Martius, usada como remédio popular no Rio Grande do Sul. Universidade Federal do Rio Grande do Sul, Santa Maria, Brasil. 46p.

Buchet, M. 1990 Panama - A legendary hat. Ediciones Libri Mundi. Quito, Ecuador.

Caballero, J. 1991 Use e management of Sabal palms among the Maya of Yucatán: A case of technological innovation based on the folk biological knowledge. In: Rhoades, R. E., Sandoval, V.N. e Bagalanon, C.P. (eds.) Best Paper Awards 1990. Manila Philippines International Potato Center and User's Perspective with Agricultural Research and Development (UPWARD), p. 13-23.

Caballero, J., Pulido, M.T. y Martínez-Ballesté, A. El uso de la palma de guano (Sabal spp.) en la industria turística de Quintana Roo, México. In: Alexiades, M.N. y Shanley, P. (eds.) 2004 Productos forestales, medios de subsistencia y conservación: Estudios de caso sobre sistemas de manejo de 
productos forestales no maderables. Volumen 3 - América Latina. Centro para la Investigación Forestal Internacional (CIFOR), Bogor, Indonesia.

Carrillo Trueba, C. 2002 Las plantas en la vida de los pueblos de la Chinantla Baja. Tesis profesional. Universidad Nacional Autónoma de México (UNAM), México.

Challenger, A. 1998 Utilización y conservación de los ecosistemas terrestres de México. Pasado, presente y futuro. Comisión Nacional para la Biodiversidad (CONABIO), Universidad Nacional Autónoma de México (UNAM), Agrupación Sierra Madre, México.

Domínguez, M. 1991 El sombrero de paja toquilla. Historia y Economía, Banco Central del Ecuador.

Eccardi, F., Carrillo Trueba, C., Musalem, N. y Ramos, C. 2001 La palma camedora en México. Estudio elaborado para la Comisión para la Cooperación Ambiental del Tratado de Libre Comercio de Norteamérica. Enero-junio de 2001 (manuscrito).

Edouard, F. y Tickin, T. 2001 Hacia un manejo sostenible de la pita o ixtle (Aechmea magdalenae), Colección Manejo Campesino de Recursos Naturales de la red RAISES. 94P.

Herrera, N.D. 1994 Los huertos familiares Mayas en el Oriente de Yucatán. Etnoflora Yucatanense, No. 9. Universidad Autónoma de Yucatán, Mérida.

Hodel, D.R. 1992 Chamaedorea Palms. The International Palm Society/Allen Press, Lawrence, Kansas.

Marquesini, N.R. 1995 Plantas usadas como medicinais pelos índios do Paraná e Santa Catarina, sul do Brasil. Tese, Universidade Federal do Paraná, Curitiba.

Martinez-Crovetto, R. 1981 Las plantas utilizadas en medicina popular en el noroeste de Corrientes (República Argentina). Tucuman, Ministerio de Cultura y Educación/Fundación Miguel Lillo. Miscelanea No. 69.

Oyama, K. 1984 Biología comparativa entre individuos masculinos y femeninos de Chamaedorea tepejilote (Palmae). Tesis profesional. Facultad de Ciencias, Universidad Nacional Autónoma de México (UNAM), México.

Oyama, K. 1990 Variation in growth and reproduction in the neotropical dioecius palm Chamaedorea tepejilote. Journal of Ecology 78: 648-663. 
Oyama, K. e Mendoza, A. 1990 Effects of defoliation on growth, reproduction and survival of a neotropical dioecius palm, Chamaedorea tepejilote. Biotropica 22(2): 119-123.

Sanjuán, R., Gonzalez, J.M. y Huerta, M. 2000 Fuente y arte del piteado Oaxaca, Jalisco. Gobierno del Estado de Jalisco/Secretaría de Promoción Económica, México. 227p.

Santos, E.J. 1996 La pita o Ixtle, Aechmea magdalenae (André) André ex Baker, en las selvas de la Chinantla, Oaxaca. Inédito, México. 15p.

Scheffer, M.C. 2004 Produção de espinheira-santa (Maytenus ilicifolia Mart. ex Reiss) na região metropolitana de Curitiba, Paraná, Brasil. In: Alexiades, M.N. y Shanley, P. (eds.) 2004 Productos forestales, medios de subsistencia y conservación: Estudios de caso sobre sistemas de manejo de productos forestales no maderables. Volumen 3 - América Latina. Centro para la Investigación Forestal Internacional (CIFOR), Bogor, Indonesia.

Schultes, R.E. 1941 Plantae Mexicanae IX: Aechmea magdalenae and its utilization as a fiber plant. Botanical Museum leaflets 9(7): 117-122.

Steenbock, W. 2000 Medicinal plants: Popular knowledge survey, alternative therapeutics, option of income and environmental conservation in the centre of Paraná State, Brazil. Revista da Sociedade de Olericultura do Brasil 13 (Suplemento): 137-140.

Steenbock, W. 2004 Em busca do manejo sustentável da carqueja (Baccharis trimera Lers) na região central do Paraná, sul do Brasil. In: Alexiades, M.N. y Shanley, P. (eds.) Productos forestales, medios de subsistencia y conservación: Estudios de caso sobre sistemas de manejo de productos forestales no maderables. Volumen 3 - América Latina. Centro para la Investigación Forestal Internacional (CIFOR), Bogor, Indonesia.

Stellfeld, C. 1934 A espinheira-santa: Contribuição ao estudo farmacognóstico. Boletim da Associação Brasileira de Pharmacia 15: 551-571.

Tickin, T. 1999 Etnoecology de Aechmea magdalenae. Tesis de Doctorado. Universidad McGill de Montreal, Canada.

Toledo, V.M., Carabias, J., Mapes, C. y Toledo, C. 1985 Ecología y autosuficiencia alimentaria. Siglo XXI editores, México.

Zona, S. 1990 A monograph of Sabal (Arecaceae: Coryphoideae). Aliso 12(4): 583-666. 


\section{Sementes/Raízes/Brotos}

Atal, C.K. e Kapur, B.M. (eds.) 1982 Cultivation and utilization of medicinal plants. Regional Research Laboratory, Jammu-Tawi-India.

Barros Henriques, R.P. e Elias Girnos de Sousa, E.C. 1989 Population structure, dispersion and microhabitat regeneration of Carapa guianensis in northeastern Brazil. Biotropica 21(3): 204-209.

Brown, H.A., Minott, D.A., Ingram, C.W. e Williams, L.A.D. 1998 Biological activities of the extracts and constituents of Pimiento, Pimenta dioica L. against the southern cattle tick, Boophilus microplus. Insect Science and its Application 18: 9-16.

Clay, J.W., Sampaio, P. de T.B. e Clement, C.R. 1999 Biodiversidade Amazônia: Exemplos e estratégias de utilização. Instituto Nacional de Pesquisas da Amazonia (INPA) e Serviço Brasileiro de Apoio a Micro e Pequenà Empresa (SEBRAE). Manaus, Brasil. 409p.

Corrêa Júnior, C. e Ming, L.C. 2004 Fáfia (Pfaffia glomerata (Spreng.) Pedersen): O ginseng Brasileiro. In: Alexiades, M.N. y Shanley, P. (eds.) 2004 Productos forestales, medios de subsistencia y conservación: Estudios de caso sobre sistemas de manejo de productos forestales no maderables. Volumen 3 - América Latina. Centro para la Investigación Forestal Internacional (CIFOR), Bogor, Indonesia.

Fantini, A.C. 1999 Palm heart (Euterpe edulis) production and management in the Brazilian Mata Atlântica. Tese de Doutorado, University of Wisconsin, USA. 127P.

Fantini, A.C., Guries, R.P. e Ribeiro, R.J. 2004 Palmito (Euterpe edulis Martius) na Mata Atlântica Brasileira: Um recurso em declínio. In: Alexiades, M.N. y Shanley, P. (eds.) 2004 Productos forestales, medios de subsistencia y conservación: Estudios de caso sobre sistemas de manejo de productos forestales no maderables. Volumen 3 - América Latina. Centro para la Investigación Forestal Internacional (CIFOR), Bogor, Indonesia.

FAO (Food and Agriculture Organization of the United Nations) 1990-2001 FAO Statistical Databases - Agriculture. (www.apps.fao.org/page/collections/subset=agriculture)

Higbee, E.C. e Kelly, J.W. 1950 Possibilities of improving ipecac root by selection. American Journal of Pharmacology 122: 184-188.

Macia, M.J. 1998 La pimienta de Jamaica (Pimenta dioica (L.) Merril, Myrtaceae) en la Sierra Norte de Puebla (México). Anales del Real Jardín Botánico, Madrid 56: 337-349. 
Magalhães, P.M. 2000 Agrotecnología para el cultivo de fáfia o ginseng Brasileiro. In: Fundamentos de agrotecnología de cultivo de plantas medicinales Iberoamericanas. Ciencia y Tecnología para el Desarrollo (CYTED), Bogotá, Colombia.

Martínez, M.A, Evangelista, V., Mendoza, M.C., Basurto, F. y Mapes, C. 2004 Estudio de la pimienta gorda, Pimenta dioica (L.) Merrill, un producto forestal no maderable de la Sierra Norte de Puebla, México. In: Alexiades, M.N. y Shanley, P. (eds.) 2004 Productos forestales, medios de subsistencia y conservación: Estudios de caso sobre sistemas de manejo de productos forestales no maderables. Volumen 3 - América Latina. Centro para la Investigación Forestal Internacional (CIFOR), Bogor, Indonesia.

Martínez, M.A., Evangelista, V., Mendoza, M.C., Morales, G., Toledo, G. y Wong, A. 2001 Catálogo de plantas útiles de la Sierra Norte de Puebla, México. Cuadernos 27. Instituto de Biología, Universidad Nacional Autónoma de México (UNAM), México.

Merril, E.D. 1947 The technical name of allspice. Contributions from the Gray Herbarium of Harvard University CLXV: $30-38$

Ming, L.C. e Corrêa Júnior, C. 2001 Collection of fáfia (Pfaffia glomerata (Spreng.) Pedersen) in the northwest region of Paraná State, Brazil. World Conference on Medicinal and Aromatic Plants. Budapest, Hungary. 242p.

Montanari Jr., I., Magalhães, P.M. e Queiroga, C.L. 1997 Influences of plantation density and cultivation cycle in root productivity and tenors of becdysone in Pfaffia glomerata (Spreng.) Pedersen. In: Proceedings of the II World Congress on Medicinal and Aromatic Plants for Human Welfare. International Council for Medicinal and Aromatic Plants (ICMAP), International Society for Horticultural Science (ISHS), Sociedad Argentina Para la Investigación de Productos Aromáticos (SAIPA). Mendoza, Argentina, p. 10-15.

Ocampo, R.A.S. 2000 Agrotecnología para el cultivo de ipecacuana o raicilla. In: Fundamentos de Agrotecnología de cultivo de plantas medicinales Iberoamericanas. Santa Fe de Bogotá D.C., Colombia: Convenio Andrés Bello y Ciencia y Tecnología para el Desarrollo (CYTED).

Ocampo, R.A.S. 2004 Ipecacuana, Psychotria ipecacuanha (Brotero) Stokes: Un producto no maderable cultivado bajo el bosque en Huetar Norte, Costa Rica. In: Alexiades, M.N. y Shanley, P. (eds.) 2004 Productos forestales, medios de subsistencia y conservación: Estudios de caso sobre sistemas de manejo de productos forestales no maderables. Volumen 3 - América Latina. Centro para la Investigación Forestal Internacional (CIFOR), Bogor, Indonesia.

Palma, T. y Hidalgo, N. 1994 Biotecnología elemento importante en la domesticación de plantas medicinales. In: Domesticación de plantas medicinales en Centroamérica. Centro Agronómico 
Tropical de Investigación y Enseñanza (CATIE). Serie Técnica, Informe Técnico No. 245. Turrialba, Costa Rica, p. 17.

Purseglove, J.W. 1974 Tropical Crops. Dicotyledons. Longman, London, UK.

Reis, A. 1995 Dispersão de sementes de Euterpe edulis Martius - (Palmae) em uma floresta ombrófila densa montana da encosta Atlântica em Blumenau, SC. Tese de Doutorado, Universidade Estadual de Campinas, Brasil. 154P.

Reis, M.S. 1996 Distribuição e dinâmica da variabilidade genética em populaşões de palmiteiro (Euterpe edulis Martius). Tese de Doutorado, Escola Superior de Agricultura Luiz de Queiroz, Piracicaba, Brasil. 210p.

Reis, M.S. e Reis, A. (eds.) 2000 Euterpe edulis Martius (Palmiteiro) biologia, conservação e manejo. Herbário Barbosa Rodrigues, Itajaí. 335P.

Shanley, P. e Luz, L. 2003 The impacts of forest degradation on medicinal plant use and implications for health care in eastern Amazonia. Bioscience Vol. 53(6): 573-584.

Teran, E. 1990 Plantas de interesse em cosmetologia. Cosmetics and Toiletries 2(5): 18-23.

\section{Casca/Madeira}

Arce, J. 1996 Manejo de bosques para producción sostenible de uña de gato: la experiencia del valle del Palcazú. Presentación en el curso: Identificación, producción, propagación y manejo de uña de gato. Universidad Nacional Agraria La Molina. 13-15 Noviembre 1996, Lima.

Chibnik, M. 2003 Crafting tradition. The making and marketing of Oaxacan wood carvings. University of Texas Press, Austin, USA. 266p.

de Jong, W., Melnyk, M., Alfaro Lozano, L., Rosales, M. e García, M. 1998 Uña de gato: Fate and future of a Peruvian forest resource. Center for International Forestry Research (CIFOR) Occasional Paper No. 18. Bogor, Indonesia.

de Jong, W., Melnyk, M., Alfaro, L., Rosales, M. e García, M. 2000 A concerted approach to uña de gato development in Peru. International Tree Crop Journal 10(4): 321-337.

Lenz, H. 1973 El papel indígena Mexicano. Serie Cultura Sep Setentas No. 65. Editorial Cultura Sep Setentas, México. 186p. 
López, C. 1992 El papel amate. Sagrado, profanado y proscrito Ciencias (28): 31-36. Revista de la Facultad de Ciencias, Universidad Nacional Autónoma de México (UNAM), México.

López, C. 2004 "Amate" papel de corteza Mexicano (Trema micrantha (L.) Blume): Nuevas estrategias de cosecha para enfrentar las demandas de mercado. In: Alexiades, M.N. y Shanley, P. (eds.) 2004 Productos forestales, medios de subsistencia y conservación: Estudios de caso sobre sistemas de manejo de productos forestales no maderables. Volumen 3 - América Latina. Centro para la Investigación Forestal Internacional (CIFOR), Bogor, Indonesia.

Moguel, P. e Toledo, V.M. 1999 Biodiversity conservation in traditional coffee systems of Mexico. Conservation Biology 13(1): 11-21.

Nalvarte, W. y de Jong, W. 2004 Uña de gato (Uncaria tomentosa (Willd. Ex Roem. \& Schult) DC. y Uncaria guianensis (Aubl.) Gmel.): Potencial y esperanzas de un bejuco Amazónico del Perú. In: Alexiades, M.N. y Shanley, P. (eds.) 2004 Productos forestales, medios de subsistencia y conservación: Estudios de caso sobre sistemas de manejo de productos forestales no maderables. Volumen 3 - América Latina. Centro para la Investigación Forestal Internacional (CIFOR), Bogor, Indonesia.

Peters, C.M., Purata, S.E., Chibnik, M., López, A.M., Brosi, B.J. e Ambrosio, M. 2003 The life and times of Bursera glabrifolia (H.B.K.) Engl. in Mexico: A parable for ethnobotany. Economic Botany 57(4): 431-441.

Peters, C.M., Rosenthal, J. e Urbina, T. 1987 Otomi bark paper in Mexico: Commercializaton of a preHispanic technology. Economic Botany 41(3): 424-432.

Purata, S.E., Chibnik, M., Brosi, B., y López, A.M. 2004 Figuras de madera de Bursera glabrifolia H.B.K. (Engl.) en Oaxaca, México. In: Alexiades, M.N. y Shanley, P. (eds.) 2004 Productos forestales, medios de subsistencia y conservación: Estudios de caso sobre sistemas de manejo de productos forestales no maderables. Volumen 3 - América Latina. Centro para la Investigación Forestal Internacional (CIFOR), Bogor, Indonesia.

Purata, S.E., Peters, C.M., Ambrosio, M., Brosi, B.J. y López, A.M. 2004 Los alebrijes de Oaxaca y el manejo de las selvas secas. Ciencia y Desarrollo 30(174): 52-60.

Vázquez-Yanes, C. 1998 Trema micrantha (L.) Blume (Ulmaceae): A promising neotropical tree for site amelioration of deforested land. Agroforestry Systems 40: 97-104. 
Zavala Carillo, C.A. y Zevallos Pollito, P. 1996 Taxonomía, distribución geográfica y status del género Uncaria en el Perú: Uña de gato. Universidad Nacional Agraria La Molina, Facultad de Ciencias Forestales, Lima, Perú.

\section{Exsudatos}

Altamirano, F. 1904 Datos para el estudio del árbol de Lináloe y su esencia. Anales del Instituto Medio Nacional México 6: 69.

Betancourt, Y. 1980 Investigaciones fundamentales para la determinación de las tecnologías de resinación de Pinus caribaea var. caribaea. Tesis en opción al grado de Doctor en Ciencias Forestales. Dresden, Alemania. 220p.

Betancourt, Y. y Villalba, M.J. 2000 El uso de los estimulantes como la vía más inmediata para incrementar los rendimientos de resina en los pinos Cubanos. I SIMFOR. Universidad de Pinar del Río.

Betancourt, Y., Bustamante, J.F., Villalba Fonte, M.J. y Nuñez, S.G. 2004 Aprovechamiento de la resina en Pinus caribaea Morelet var. caribaea Barrett y Golfari. In: Alexiades, M.N. y Shanley, P. (eds.) 2004 Productos forestales, medios de subsistencia y conservación: Estudios de caso sobre sistemas de manejo de productos forestales no maderables. Volumen 3 - América Latina. Centro para la Investigación Forestal Internacional (CIFOR), Bogor, Indonesia.

Bustamante, J.F. 1999 Procesamiento de la resina de Pinus caribaea, var. caribaea y sus componentes para la obtención de productos resinosos. Tesis al Grado Científico de Dr. en Ciencias Forestales, Universidad de Pinar del Río, Cuba. 180p.

de Andrade, A.G. 1998 Um novo produto florestal não-madeireiro: O "couro vegetal". Estudo de uma situação extrativista. Relatório de pesquisa Fundação de Amparo à Pesquisa do Estado de São Paulo (FAPESP), São Paulo, Brasil.

Emperaire, L. 1997 L'exploitation des héveas dans la Réserve Extractiviste du Haut Juruá (Acre, Amazonie Brésilienne). In: Journal d'Agriculture Traditionnel et de Botanique Applique (JATBA), Revue d'Ethnobiologie 39: 109-132.

Emperaire, L. e de Almeida, M.B. 2002 "Seringueiros e seringas". In: Carneiro da Cunha, M. e de Almeida, M.B. Enciclopédia da Floresta. Alto Juruá: Conhecimentos e práticas das populações. São Paulo, Companhia da Letras, p. 285-309. 
Hersch-Martínez, P., Glass, R. y Fierro, A.A. 2004 El linaloe (Bursera aloexylon (Schiede) Engl.): Una madera aromática entre la tradición y la presión económica. In: Alexiades, M.N. y Shanley, P. (eds.) 2004 Productos forestales, medios de subsistencia y conservación: Estudios de caso sobre sistemas de manejo de productos forestales no maderables. Volumen 3 - América Latina. Centro para la Investigación Forestal Internacional (CIFOR), Bogor, Indonesia.

Medina, I. 1997 Maque prehispánico: Una antigua discusión. In: Lechuga, R. et al. (eds.) Lacas Mexicanas. Museo Franz Mayer y Artes de México, p. 21-27.

Pantoja, M.C. 2004 Couro vegetal: O látex (Hevea brasiliensis Müll. Arg.) na moda. In: Alexiades, M.N. y Shanley, P. (eds.) 2004 Productos forestales, medios de subsistencia y conservación: Estudios de caso sobre sistemas de manejo de productos forestales no maderables. Volumen 3 - América Latina. Centro para la Investigación Forestal Internacional (CIFOR), Bogor, Indonesia.

Rzedowski, J. 1998 Diversidad y orígenes de la flora fanerogámica en Mexico. In: Diversidad biológica de México. Orígenes y distribución. Ramamoorthy, T.P. et al. (eds.) Universidad Nacional Autónoma de México (UNAM), México.

Samek, V. y Del Risco, E. 1989 Los pinares de la provincia de Pinar del Río, Cuba. Estudio Sinecológico, Editorial Academia, La Habana.

Silberling, L., Pantoja, M.C. e Anderson, A. 2002 Couro vegetal: Desenvolvimento de um produto artesanal para o Mercado. In: Anderson, A. e Clay, J. 2002 Esverdeando a Amazônia: Comunidades e empresas em busca de práticas para negócios sustentáveis. Peirópolis, São Paulo, p. 105-119.

Toledo Manzur, C.A. 1982 El género Bursera (Burseraceae) en el Estado de Guerrero (México). Facultad de Ciencias, Universidad Nacional Autónoma de México (UNAM), México. 


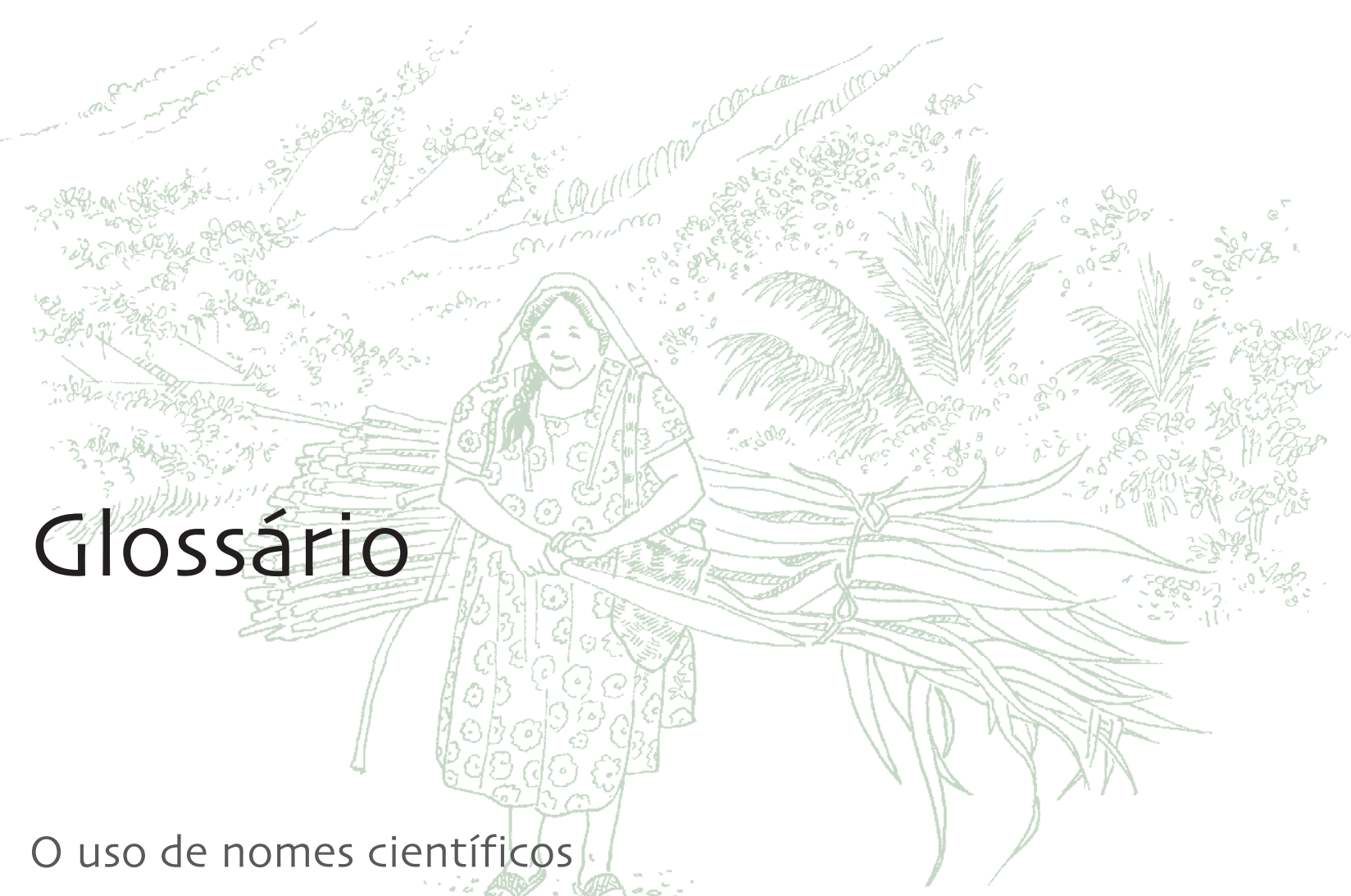

No início de cada caso deste livro você encontrará os nomes científicos das diferentes plantas (e animais) florestais apresentadas. A classificação biológica nos ajuda a entender o mundo natural e a estruturar nosso conhecimento. Ela permite às pessoas identificar e registrar espécies, fornecendo uma linguagem universal de comunicaşão e servindo como uma importante ferramenta para a conservação da natureza.

Cada espécie tem um nome científico composto por duas palavras latinas. A primeira refere-se ao gênero, enquanto a segunda refere-se à espécie propriamente dita. Além disso, aparecem o nome ou iniciais da pessoa (ou pessoas) que publicou a primeira descrição científica daquela espécie (por exemplo: Ruiz \& Pavón). Quando nos referimos a plantas, usamos o sistema de 'nomenclatura botânica' para distinguir e identificar as diferentes espécies, pelas seguintes razões:

\section{Reconhecimento universal}

Uma planta pode ser identificada em qualquer país do mundo usando o seu nome botânico, eliminando assim a barreira das diferentes línguas.

\section{Relações}

A relação entre plantas pode ser facilmente determinada pelo exame da classificaşão botânica. 


\section{Identificação}

Os nomes comuns são problemáticos e variam muito entre localidades. Por exemplo, o nome 'fáfia' poderia se referir a qualquer uma das mais de 70 espécies dentro do gênero Pfaffia.

\section{Origens}

A origem das plantas pode ser estabelecida pelo seu nome. Por exemplo, indicando se a espécie é um híbrido (isto é, produto do cruzamento de duas espécies ou variedades diferentes de plantas).

\section{Gênero}

Os nomes dos gêneros sempre são escritos em itálico e comesam com letra maiúscula. Eles podem ser derivados do nome de um famoso botânico ou de nomes latinos clássicos relacionados a uma importante planta. Por exemplo, o nome do gênero Bursera foi dado em homenagem a J. Burser, um botânico do século XVII. Em outros casos, são também utilizadas formas latinizadas de nomes mais comuns de línguas como o francês e o inglês.

\section{Espécie}

O nome de uma espécie é formado pelo nome do gênero e por um epíteto (adjetivo ou modificador) particular para a espécie, como por exemplo: Orbignya phalerata. O nome da espécie nos permite distinguir exatamente a planta a qual nos referimos dentro de um dado gênero. Os nomes de espécies são sempre escritos em itálico e com letras minúsculas, e são normalmente descritivos. Por exemplo, eles podem informar a origem da planta, como no caso do Pinus caribaea (proveniente do Caribe) e Hevea brasiliensis (proveniente do Brasil). Podem também descrever a planta ou animal, como o nome Uncaria tomentosa, cunhado em 1830 do latim uncus, que quer dizer unha, garra, e tomentosa, que quer dizer pêlo fino. Finalmente, quando o nome da espécie tem o sufixo -i ou -ii, significa que a escolha do nome da planta ou animal é uma homenagem a alguém. Por exemplo, Cassipourea flanaganii é um nome dado em homenagem a Henry George Flanagan, um botânico sul-africano do século XIX.

\section{Subespécie}

Às vezes, dentro de uma espécie há significativa variação, mas não suficiente para se estabelecer uma outra espécie. Nesse caso, a classificação 'subespécie' é usada. Da mesma forma que os nomes das espécies, os nomes de subespécies são sempre escritos em itálico, com letras minúsculas, e são geralmente descritivos, como, por exemplo, Hevea guianensis subsp. marginata e Hevea guianensis subsp. occidentalis. 


\section{Variedade}

Dentro de uma espécie ou subespécie, pode haver, ainda, moderada variaşão, tornando-se necessária a classificasão mais sutil de 'variedade'. Os nomes das variedades são sempre escritos inteiramente com letras minúsculas em itálico e, novamente, geralmente são descritivos. Exemplos: Pinus caribaea var. caribaea, Pinus caribaea var. hondurensis e Pinus caribaea var. bahamensis.

Acahuales (pousio, em português) - Termo usado em áreas tropicais do México, e se refere à terra anteriormente usada para agricultura e que está novamente sendo convertida em vegetasão florestal.

Adstringente - Substância que tem propriedades refrescantes, pegajosas ou secantes quando aplicadas à pele. Na medicina, o termo se refere a uma substância que tem propriedades de provocar contração ou encolhimento, ou, em termos de paladar, um sabor desagradável, seco (por exemplo, como nos vinhos, devido à presença do tanino).

Alcalóides - Uma classe de compostos orgânicos nitrogenados básicos que ocorrem nas plantas (tais como a nicotina ou a morfina).

Análogo - Material que pode ser usado como substituto de outro, devido à sua estrutura ou aparência similar. Um exemplo é a fáfia (Pfaffia glomerata), que por apresentar aparência e propriedades similares ao ginseng asiático é usada como um substituto deste popular fitoterápico.

Anticoagulante - Substância que reduz ou previne a coagulaşão de fluidos como o sangue ou o látex de plantas, isto é, reduz a transformação desses fluidos em uma massa espessa.

Antiinflamatório - Medicamento ou substância com propriedades que ajudam a reduzir a inflamaşão e inchaşo associados a certas doenças.

Apical - Região da ponta de cada broto e raiz das plantas, onde as divisões celulares estão ocorrendo continuamente para produzir novos tecido do caule e da raiz, respectivamente.

Bainha - Base da folhas que forma uma capa protetora em volta do caule.

Biodiversidade - Diversidade biológica. A variedade de vida em todas as suas formas, níveis e combinasões - incluindo a diversidade de ecossistemas, de espécies e a diversidade genética.

Cabasa - O fruto de qualquer das várias plantas da família das cucurbitáceas ou similares. Este termo se relaciona especialmente às abóboras, cujas duras cascas são usadas para fazer ornamentos, cuias, etc.

Caboclos - Refere-se aos mestiços de indígenas e europeus. Milhões de brasileiros têm algum tipo de ancestral índio nativo, geralmente pelo lado de seus avós ou bisavós, o que acontece especialmente na região amazônica. 
Café sombreado - Plantações nas quais os pés de café crescem à sombra de árvores. As árvores ajudam a reter e aumentar a concentração de nutrientes do solo, e atenuam o calor e a luz que atinge as plantas de café. Além de fornecer sombra, as árvores geralmente têm outros usos para os agricultores (tais como madeira, casca ou frutas), e também fornecem alimento e abrigo para a vida silvestre.

Campos nativos/Pastagens naturais - Área onde a vegetação natural consiste principalmente de gramíneas perenes, com árvores limitadas aos vales ou bem esparsas; características dos climas sub-úmidos e semiáridos.

Certificação - O processo de autorizasão oficial. Em termos de manejo da floresta, envolve a verificação, por exemplo, de que os produtos sejam produzidos organicamente (sem o uso de agroquímicos) e de que sejam coletados de maneira sustentável, obedecendo a certos padrões e requisitos pré-determinados.

Cobertura morta - Material orgânico (como palha ou composto) que é enterrado no solo ou espalhado na superfície em volta da base das plantas. Serve para proteger as plantas, conservar a umidade do solo, reduzir as ervas daninhas e fornecer nutrientes para as plantas.

Colheita/Exploraşão sustentável - É alcançada seguindo-se normas de manejo ou colheita que permitem a extraşão do produto ao mesmo tempo em que promove a regeneraşão da espécie colhida em determinada área. Medidas são adotadas para assegurar que a extração de um tipo particular de produto vegetal ou animal não afete negativamente a capacidade de recuperaşão dos estoques remanescentes.

Coníferas - Árvores sempre verdes que produzem cones (como os pinheiros e os ciprestes).

Conquistadores - Este termo se refere aos conquistadores espanhóis ou aventureiros, especialmente no contexto da exploração do México, Peru ou América Central no século XVI.

Conselho de Manejo Florestal (sigla em inglês: FSC) - organizasão internacional que apóia a administração ambientalmente correta, com benefício social e economicamente viável da floresta. Quando um produto florestal apresenta o logotipo da FSC, é uma indicação de que inspetores independentes atestam que ele vem de uma floresta bem manejada, de acordo com rígidos critérios ambientais, sociais e econômicos.

Cristais de oxalato de cálcio - Longos e finos cristais microscópicos (rafídeos) ricos em cálcio, encontrados nos tecidos de plantas. São muito comuns em espinafre, nas aráceas e nas palmeiras.

Cultivar - Uma variedade de plantas que tem sido produzida somente sob cultivo.

Decocsão - Preparasão obtida pela fervura de uma substância (como uma erva) em água, para extrair seus ingredientes ativos.

Densidade - Número de plantas por unidade de área (normalmente hectare, que corresponde a uma área de $100 \times 100 \mathrm{~m}$ ).

Diurético - Medicamento ou substância que aumenta o volume de urina produzida. 
Diversidade Genética - A diversidade biológica, decorrente dos diferentes arranjos do código genético em diferentes espécies e em diferentes indivíduos da mesma espécie.

Domesticado/Domesticaşão - Processo pelo qual plantas ou animais silvestres são retidos ou integrados aos sistemas agrícolas ou quintais, às vezes envolvendo cruzamento seletivo por muitas gerasões para melhorar características desejadas para o benefício humano.

Dossel - A camada superior de copas das árvores de uma floresta, que proporciona uma camada de luz filtrada para as árvores e plantas do sub-bosque.

Ecologia - Estudo das interações entre os seres vivos e destes com o meio físico.

Ecossistema - Uma comunidade de seres vivos interagindo entre si e com o meio físico em que vivem.

Ejidatário - Um membro de um ejido (veja o próximo verbete), isto é, um indivíduo que tem interesses nos benefícios de uma terra comunitária do tipo ejido.

Ejido - Uma área de terra agrícola de propriedade comunitária mas cultivada em lotes familiares individuais. Os Ejidos emergiram como uma forma mexicana particular de redistribuir grandes áreas de terra no início do século XIX.

Endocarpo - A parede das frutas mais próxima das sementes. Em algumas frutas, como o uxi, ela se torna dura e "petrificada".

Enzima - Qualquer proteína capaz de facilitar uma reaşão química necessária para uma célula ou organismo.

Estacas - Pequenas seções de uma planta, normalmente tomadas dos ramos, usadas para propagação. São cultivadas em uma solução ou solo até que novos brotos ou raízes apareçam. Uma vez estabelecidas, essas estacas podem ser transplantadas.

Estuário - Desembocadura de um rio no mar, sujeita aos efeitos das marés.

Fertilização cruzada - O processo de fertilizacão em que o pólen de outras plantas (da mesma espécie) é necessário para fertilizar uma flor. É o oposto da autofecundação, onde tanto o óvulo quanto o pólen pertencem à mesma flor ou planta.

Flavonóides - Pigmentos de plantas. São os mais importantes pigmentos envolvidos na coloração das flores e provavelmente ocorrem em todas as plantas com flores.

Florestas com araucária - Florestas que ocorrem no hemisfério sul, dominadas por árvores coníferas pertencentes a esse gênero. No Brasil, essas florestas são dominadas pelo pinheiro brasileiro ou pinheirodo-paraná (Araucaria angustifolia).

- Vegetação florestal formada por árvores e arbustos que crescem ao longo ou próximos a um rio, lago ou charco. Em alguns casos os sistemas radiculares estão debaixo da água. Também é conhecida como 'floresta ripária'. 
Floresta primária - Floresta madura, em clímax.

Floresta secundária - Floresta que se desenvolve depois de um grande distúrbio da vegetacão original. A nova vegetasão geralmente difere em estrutura e composiç̃o de espécies em comparação à floresta primária.

Fotossíntese - Processo pelo qual as plantas convertem energia luminosa em energia química. Ela ocorre nos 'cloroplastos', dentro das células vegetais, onde a energia da luz solar é usada para converter água e dióxido de carbono em carboidratos.

Frondes - Folhas finamente divididas, geralmente grandes, dos xaxins, das samambaias e de algumas palmeiras.

Gênero - Na classificasão biológica, o gênero representa a forma comum de subdivisão dentro de uma família ou subfamília. Geralmente contém mais de uma espécie, essencialmente muito similares entre si e consideradas como proximamente aparentadas. A designaşão gênero é a primeira parte de um nome científico, como em Endopleura uchi, a árvore do uxi.

Geneticamente idênticos - Organismos que compartilham o mesmo código genético. Por exemplo, plantas que se originam de brotações das plantas parentais.

Genético - Relacionado ao código genético: o arranjo dos cromossomos, genes e ácido desoxirribonucléico (ou DNA) encontrado nas células vivas. Esse código carrega o material hereditário dos organismos vivos e é passado dos pais para os descendentes.

Germinar - Rebentar, comeşar a desenvolver (a semente).

Gringos - Termo pejorativo usado na América Latina para se referir às pessoas brancas, que falam inglês, geralmente dos Estados Unidos, e especialmente no contexto da sua suposta interferência econômica, cultural e política na América Latina.

Habitat - O ambiente de um organismo ou espécie; o lugar onde ele normalmente vive.

Herbácea - Planta não-lenhosa; do tipo erva.

Híbrido - A reprodução de descendentes como resultado do cruzamento entre dois pais geneticamente distintos. Em termos de cruzamento de plantas, as duas plantas parentais diferem nas características que exibem. Por exemplo, uma variedade selvagem e uma domesticada podem ser combinadas na tentativa de melhorar as qualidades dos frutos ou da casca das plantas.

Igapó - Zona de transição entre a terra firme e os corpos d'água permanente ou sazonalmente inundadas com água doce, salobra ou do mar. Varia de pequenos lagos temporários rasos a pântanos e brejos mais permanentes. 
Indígena - Originário ou ocorrendo naturalmente em uma região particular ou país, nativo de uma área.

Madeira dura/Folhosa - Espécie arbórea pertencente à classe 'dicotiledônea' das angiospermas (plantas com flores), caracterizadas por apresentarem duas folhas quando as sementes germinam, e partes das flores em múltiplos de quatro ou cinco. É uma denominação geral para as madeiras mais duras das dicotiledôneas, em oposição ás coníferas.

Manejo sustentável - Manejo local de uma determinada espécie que envolve o planejamento e o estabelecimento de normas para evitar a superexploraşão e garantir que ocorra a regenerasão natural ou artificial da espécie, assegurando a disponibilidade futura do recurso.

Matéria orgânica - Material biológico, rico e fértil presente no solo e sobre este, composto principalmente de folhas e madeira em decomposição, juntamente com outros elementos biológicos e microrganismos.

Mestiço (Mestizo, em espanhol) - Pessoa de ancestralidade combinada, com pais ou ancestrais de diferentes origens raciais. Esse termo se refere particularmente aos latino-americanos com ancestrais indígenas e europeus. Os mestiços formam a maior parte da população em muitos países da América Latina.

Milpa - Esse termo, da língua indígena mexicana Nahuatl, se refere a uma extensão de terra usada para cultivar milho e outras culturas, como tomate e feijão.

Monocultura/Monocultivo - O uso da terra para cultivar apenas uma espécie de planta, apenas uma cultura.

Mucilagem - Secreção pegajosa ou gelatinosa presente em algumas plantas, normalmente recobrindo as sementes.

Nativo - Originário ou que ocorre naturalmente em uma região particular ou país; indígena de uma área.

Pecíolo - Eixo que liga a lâmina da folha ao caule da planta.

Pectinas - Moléculas compostas principalmente de asúcares ácidos (carboidratos), que podem ser encontrados na parede celular das plantas. Normalmente as pectinas estão presentes em uma forma insolúvel, mas em frutos maduros elas mudam para uma forma solúvel em água.

Perene - Planta cujo ciclo de vida dura mais que dois anos.

Perenifólias - Árvores e arbustos que retêm as folhas durante todo o ano. As folhas da estação passada não caem até que a nova folhagem esteja completamente formada. É o oposto das plantas 'decíduas', que perdem suas folhas durante certa estação do ano. 
Polinização - Processo pelo qual o pólen da flor masculina (ou parte masculina de uma flor hermafrodita) fertiliza uma flor feminina (ou parte feminina de uma flor hermafrodita) da mesma espécie. Ela pode ocorrer, no caso da autofecundação, dentro da mesma flor ou entre flores diferentes numa mesma planta, ou na fecundação cruzada, entre flores diferentes de diferentes plantas, dependendo das circunstâncias e espécie. A polinização pode ser facilitada pelo vento e a água, ou por agentes como os pássaros e outros animais.

Polinização artificial - Processo pelo qual o pólen é introduzido manualmente para fertilizar as flores de determinadas plantas, facilitando o seu cruzamento ou a produção de frutos. (Ver também 'polinização')

Polinizadores - Agentes que polinizam as flores, isto é, auxiliam o processo de fertilização das plantas, incluindo pássaros, morcegos, abelhas e outros insetos.

Polpa - Porsão carnosa, geralmente macia de um fruto.

Potreiro - Porção de terra coberta por pastagens e usada para criar animais.

Pousio - Área que foi anteriormente cultivada e que é deixada sem cultivo ou não semeada por uma ou mais estacões. A terra pode ser arada e então deixada para descansar.

Produtos orgânicos - Produtos agrícolas e florestais cultivados e produzidos sem a aplicação de compostos químicos industrializados (fertilizantes artificiais, pesticidas, etc.).

Reflorestamento - Plantio de árvores em áreas onde a floresta havia sido devastada ou colhida.

Rizoma - Um grosso caule horizontal, que geralmente cresce debaixo da terra, de onde brotam o caule, para cima, e as raízes, para baixo.

Sinusite - Inflamação dos sinus (cavidade dentro de um osso ou outro tecido, especialmente em relação aos ossos faciais que conectam com as cavidades nasais).

Sistemas agroflorestais - Diversos sistemas de cultivo da terra onde árvores e plantas de lavoura são cultivadas ou manejadas em associação para aumentar a produção e também os benefícios sociais e ambientais.

Sistemas florestais seminaturais - Partes de floresta que retêm elementos de seu estado e vegetação natural, mas que têm sido usadas para cultivar plantas que podem crescer sob o dossel da floresta, ou que têm sido manipuladas de outras maneiras.

Sub-bosque - Conjunto ou estrato de plantas que crescem sob o dossel da floresta.

Sustentável / sustentavelmente - Colheita de plantas ou produtos vegetais de uma forma que não ameaça a capacidade reprodutiva ou o potencial regenerativo de uma determinada espécie dentro de uma área (e que não tem um impacto negativo sobre organismos vivos e o seu ambiente, ou à estrutura social daqueles que colhem e processam os produtos). 
Taninos - Grupo de compostos vegetais adstringentes, encontrados, por exemplo, na casca de certas espécies de acácia, ou na casca, talo e sementes de uva, (que conferem o gosto distintivo de tanino a alguns vinhos).

Testes de campo - Estudos conduzidos no campo, planejados para testar se uma particular hipótese é válida, ou se os resultados de pesquisa em laboratório serão efetivos no campo.

Tiquisque - O nome local de Xanthosoma sagittifolium (L.) Schott na Costa Rica, uma espécie da floresta tropical. Essa planta tem sido usada tradicionalmente como uma cultura de subsistência, e é muito cultivada nos trópicos americanos. As partes da planta aproveitadas são os caules tuberosos subterrâneos (que têm alto conteúdo de carboidratos e proteínas) e as folhas jovens, que se parecem com as do espinafre.

Transplante de plântulas - Replantio de mudas, originárias de sementes, para viveiros, onde podem ser monitoradas e cuidadas, ou para local definitivo.

Tuberoso / tubérculo - Que apresenta tubérculos, caules subterrâneos como a batata.

Vărzeas - Planícies localizadas em um ou em ambos os lados de um rio e que estão sujeitas à inundação quando o nível da água se eleva. 


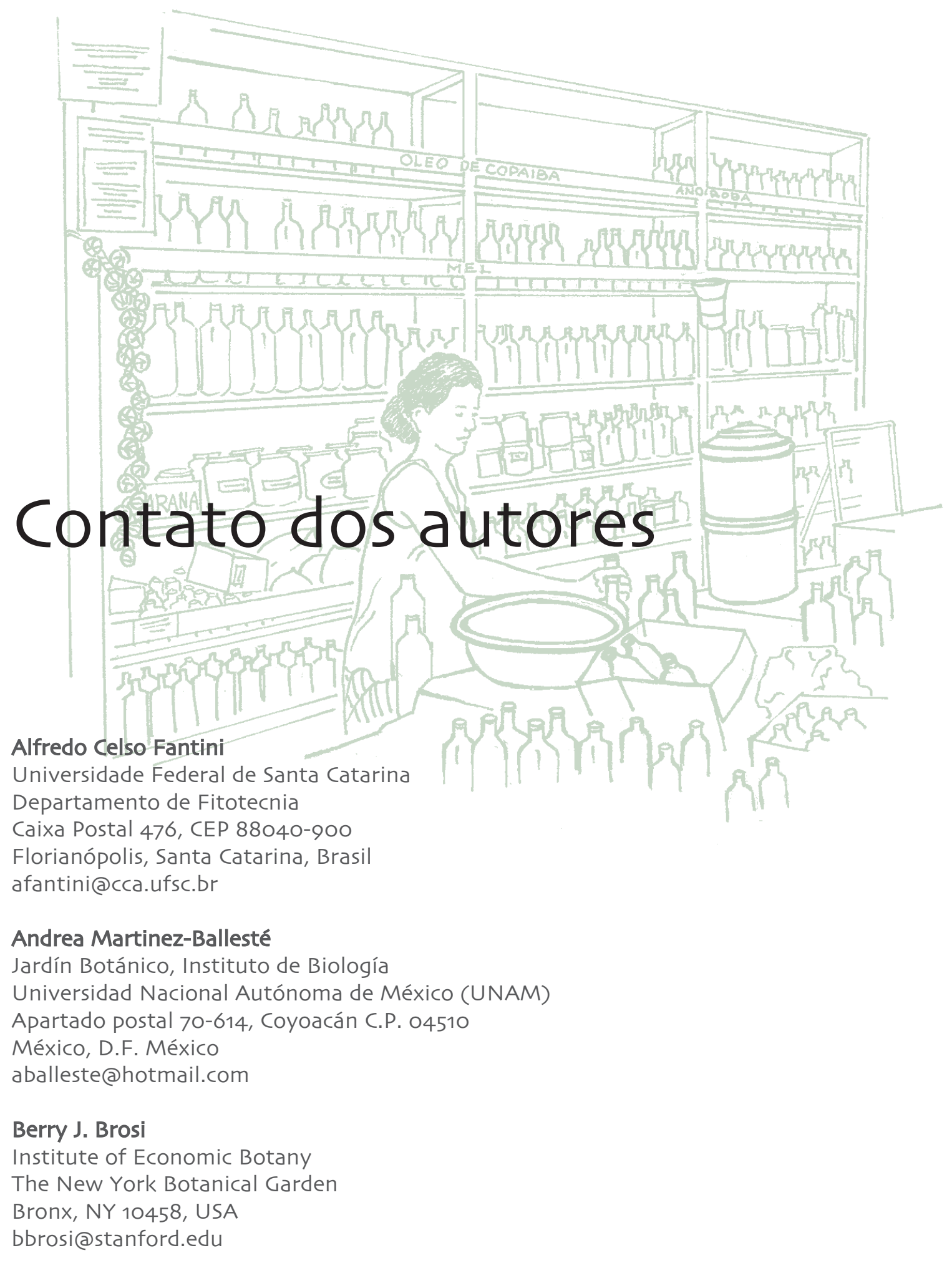




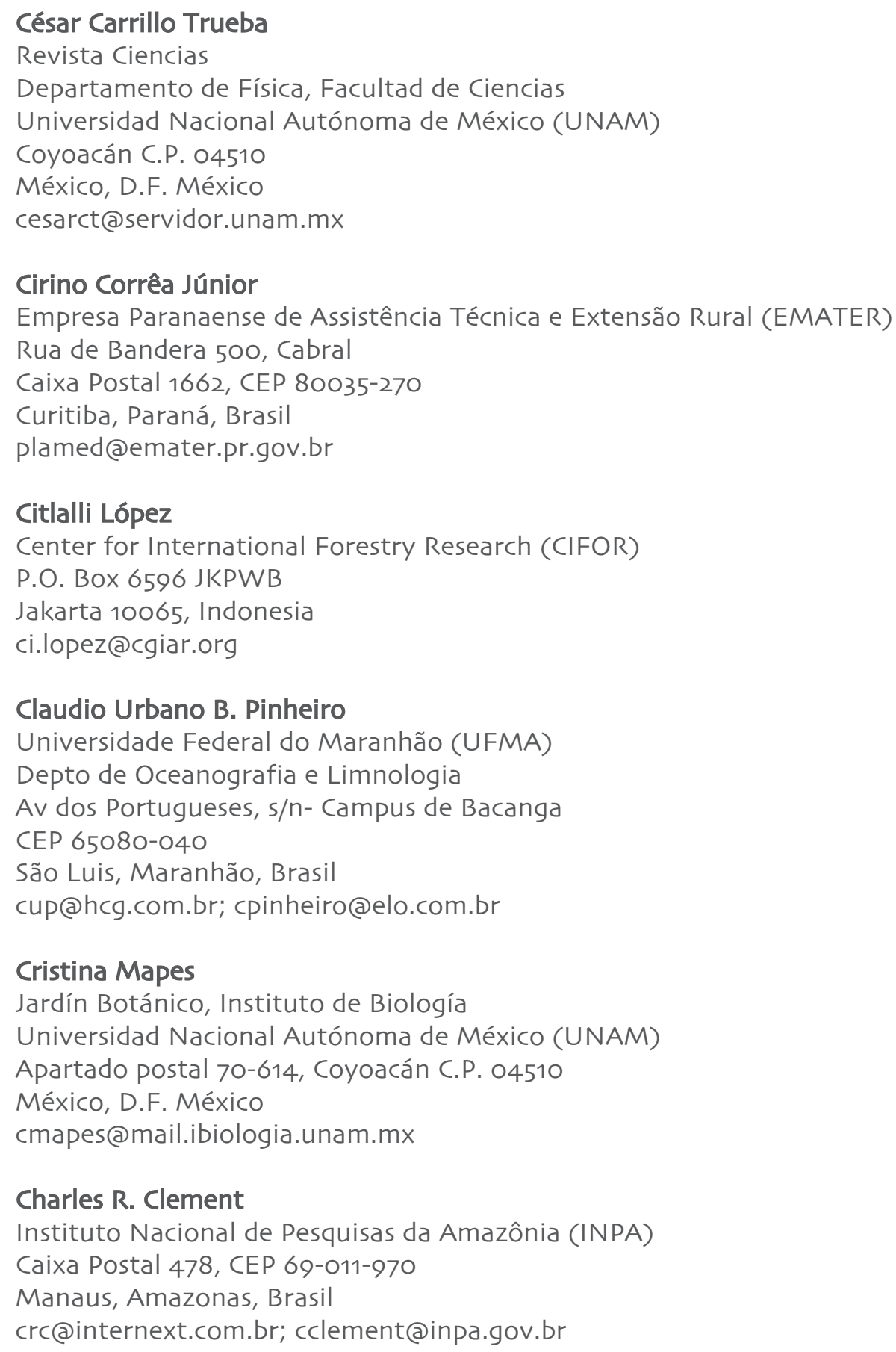

Cristina Mapes

Jardín Botánico, Instituto de Biología

Universidad Nacional Autónoma de México (UNAM)

Apartado postal 70-614, Coyoacán C.P. 04510

México, D.F. México

cmapes@mail.ibiologia.unam.mx

\section{Charles R. Clement}

Instituto Nacional de Pesquisas da Amazônia (INPA)

Caixa Postal 478, CEP 69-011-970

Manaus, Amazonas, Brasil

crc@internext.com.br; cclement@inpa.gov.br 


\section{Erik Arancibia}

United Nations Environment Programme/

World Conservation Monitoring Center (UNEP WCMC)

Casilla de correo 10326

La Paz, Bolivia

eharancibia@hotmail.com

\section{Fausto López}

Consultor independiente

Ave. 16 de Julio \#1490

Edif. Avenida, Planta Baja, Oficina 9

La Paz, Bolivia

tarakaraja@yahoo.es

\section{Fabrice Edouard}

Methodus Consultoras S.C.

Calle de Crespo 520-A

Col. Centro, C.P. 68000

Oaxaca, Oax, México

fabrice@raises.org

Sitio web: www.raises.org

\section{Francisco Basurto Peña}

Jardín Botánico, Instituto de Biología

Universidad Nacional Autónoma de México (UNAM)

Apartado postal 70-614, Coyoacán C.P. 04510

México, D.F. México

abasurto@mail.ibiologia.unam.mx

\section{Gabriel Medina}

Convênio Empresa Brasileira de Pesquisa Agropecuária (EMBRAPA)/

Center for International Forestry Research (CIFOR)

Embrapa Amazônia Oriental

Trav. Enéas Pinheiro S/N

CEP 66.905-780

Belém, Pará, Brasil

g.medina@cigar.org

\section{Gloria Gaia}

Mulheres da Mata

Instituto do Homem e Meio Ambiente da Amazônia (IMAZON)

Caixa Postal 1015, CEP 66017-000

Belém, Pará, Brasil

imazon.bel@zaz.com.br 


\section{Javier Caballero}

Jardín Botánico, Instituto de Biología

Universidad Nacional Autónoma de México (UNAM)

Apartado postal 70-614, Coyoacán C.P. 04510

México, D.F. México

jcnieto@servidor.unam.mx

\section{Lin Chau Ming}

Universidade Estadual Paulista (UNESP)

Campus Botucatu

Dep. Produção Vegetal, Setor de Horticultura

Caixa Postal 237, CEP 18603-970

Botucatu, São Paulo, Brasil

linming@fca.unesp.br

Maria Josefa Villalba Fonte

Universidad de Pinar del Río

Calle Martí No. 270, C. P. 20100

Pinar del Río, Cuba

villalba@af.upr.edu.cu

\section{María Teresa Pulido}

Jardín Botánico, Instituto de Biología

Universidad Nacional Autónoma de México (UNAM)

Apartado postal 70-614, Coyoacán C.P. 04510

México, D.F. México

mpulido@ibiologia.unam.mx

\section{Mariana Ciavatta Pantoja}

Instituto Nawa

Rua Senador Eduardo Asmar, 1111

Edifício Jerusalém - Bairro 6 de Agosto

CEP 69.901- 160

Rio Branco, Acre, Brasil

maripantoja@uol.com.br

\section{Marianne C. Scheffer}

Universidade Federal do Paraná

Caixa Postal 5336, CEP 80040-990

Curitiba, Paraná, Brasil

marianne@cce.ufpr.br 


\section{Mario Pinedo Panduro}

Calle Napo 619 Apartado Postal 471

Iquitos, Perú

mariopp@meganet.com.pe

\section{Martin Ricker}

Estación de Biología Tropical "Los Tuxtlas"

Universidad Nacional Autónoma de México (UNAM)

Apartado Postal 94, C.P. 95701

San Andrés Tuxtla, Veracruz, México

mricker@servidor.unam.mx

\section{Michael Chibnik}

Department of Anthropology, University of Iowa

114 Macbride Hall

lowa City, IA 52242-1322, USA

michael-chibnik@uiowa.edu

\section{Miguel Angel Martínez Alfaro}

Jardín Botánico, Instituto de Biología

Universidad Nacional Autónoma de México (UNAM)

Apartado postal 70-614, Coyoacán C.P. 04510

México, D.F. México

malfaro@mail.ibiologia.unam.mx

\section{Miguel N. Alexiades}

Department of Anthropology, University of Kent Canterbury $\mathrm{CT}_{2} 7 \mathrm{NS}$, United Kingdom

m.n.alexiades@kent.ac.uk

\section{Myrna Mendoza Cruz}

Jardín Botánico, Instituto de Biología

Universidad Nacional Autónoma de México (UNAM)

Apartado postal 70-614, Coyoacán C.P. 04510

México, D.F. México

myrna@mail.ibiologia.unam.mx

\section{Patricia Shanley}

Center for International Forestry Research (CIFOR)

P.O. Box 6596 JKPWB

Jakarta 10065, Indonesia

p.shanley@cgiar.org 


\section{Paul Hersch-Martínez}

Instituto Nacional de Antropología e Historia (INAH)

Matamoros 14, Acapantzingo C.P. 62440

Cuernavaca, Morelos, México

leon@buzon.uaem.mx

\section{Rafael A. Ocampo Sánchez}

Jardín Agroecológico Bougainvillea

San José, Costa Rica

quassia@racsa.co.cr

\section{Rocío Alarcón Gallegos}

Corporación de Gestión y Derecho Ambiental Ecuador (ECOLEX)

Brookfield Road, Market Harborough

Leicestershire LE16 9DU, United Kingdom

r.viteri@btopenworld.com

\section{Silvia E. Purata}

Instituto de Ecología, A.C.

km. 2.5 Antigua Carretera a Coatepec

C.P. 91070

Xalapa, Veracruz, México

silvia@ecologia.edu.mx

\section{Socorro Ferreira}

Embrapa Amazônia Oriental

Trav. Enéas Pinheiro S/N

CEP 66.905-780

Belém, Pará, Brasil

socorro@cpatu.embrapa.br

\section{Virginia Evangelista Oliva}

Jardín Botánico, Instituto de Biología

Universidad Nacional Autónoma de México (UNAM)

Apartado postal 70-614, Coyoacán C.P. 04510

México, D.F. México

voliva@mail.ibiologia.unam.mx

\section{Ynocente Betancourt Figueras}

Universidad de Pinar del Río

Calle B. Edif. 13. Apto A-3

Calero. Pinar del Río, Cuba

rolando@geo.upr.edu.cu; rolando@tele.upr.edu.cu;

betancourt@af.upr.edu.cu 


\section{Yolanda Nava-Cruz}

Estación de Biología Tropical "Los Tuxtlas"

Universidad Nacional Autónoma de México (UNAM)

Apartado Postal 94, C.P. 95701

San Andrés Tuxtla, Veracruz, México

ynava@ate.oikos.unam.mx

\section{Walter Nalvarte}

Centro para la Investigación Forestal Internacional (CIFOR)

Oficina Regional en Perú

Carretera Federico Basadre km 4,200

Pucallpa, Perú

wnalvarte@wayna.rcp.net.pe

\section{Walter Steenbock}

Fundação para o Desenvolvimento Econômico Rural da Região

Centro-Oeste do Paraná (RURECO)

Rua Jesuino Marcondes 1161

CEP 85100-970

Guarapuava, Paraná, Brasil

rureco@gol.psi.br

\section{Wil de Jong}

Center for International Forestry Research (CIFOR)

P.O. Box 6596 JKPWB

Jakarta 10065, Indonesia

w.dejong@cgiar.org 


\section{Fonte do material usado para as ilustrasões}

capa

vi

vii

ix

Página 1

página 5

Página 7

Página 8

página 9

Página 10

Página 11

Página 13

Página 14 Página 17

Página 18 Página 19 Página 20 Página 21 Página 23 Página 24 Página 25

Página 26 Página 27 Página 29

Página 30
Redesenhado de uma ilustração de Anabelle Maffioli (in ANAI Serie de Boletines Técnicos para el Agricultor, Boletín Técnico No. 3, El Pejibaye, 1986)

Baseado em foto de César Carrillo Trueba

Baseado em foto de César Carrillo Trueba

Baseado em foto de Gabriel Medina

Baseado em foto de Gabriel Medina

Platonia insignis, desenhado de uma amostra viva, Empresa Brasileira de Pesquisa Agropecuária (EMBRAPA), Belém, Brasil

Baseado em foto de Patricia Shanley

Baseado em foto de Patricia Shanley

Bactris gasipaes, desenhado de uma amostra viva, Empresa Brasileira de Pesquisa Agropecuária (EMBRAPA), Belém, Brasil

Redesenhado de uma ilustração de Anabelle Maffioli (in ANAI Serie de Boletines Técnicos para el Agricultor, Boletín Técnico No. 3, El Pejibaye, 1986)

Redesenhado de uma ilustração de Anabelle Maffioli (in ANAI Serie de Boletines Técnicos para el Agricultor, Boletín Técnico No. 3, El Pejibaye, 1986)

Myrciaria dubia, desenhado de uma amostra viva, Empresa Brasileira de Pesquisa Agropecuária (EMBRAPA), coleção de plantas medicinais, Belém, Brasil

Baseado em foto de Mario Pinedo Panduro

Orbignya phalerata, desenhado de uma foto de Harri Lorenzi (in Lorenzi, H. 1996 Palmeiras No Brasil: Nativas e Exóticas, Editora Plantarum Ltda., Brasil)

Baseado em foto de Cláudio Urbano B. Pinheiro

Baseado em foto de Alfredo C. Fantini

Baseado em foto de Cláudio Urbano B. Pinheiro

Pouteria sapota, Baseado em foto (de amostras vivas) de Martin Ricker

Baseado em foto de Martin Ricker

Baseado em foto de Martin Ricker

Endopleura uchi, desenhado de uma amostra viva, Empresa Brasileira de Pesquisa Agropecuária (EMBRAPA), Belém, Brasil

Desenhado de uma amostra

Acima: Baseado em foto de Patricia Shanley

Maytenus ilicifolia, desenhado de uma amostra viva, Empresa Brasileira de Pesquisa Agropecuária (EMBRAPA), coleção de plantas medicinais, Belém, Brasil

Esquerda: Baseado em foto de Marianne C. Scheffer 
Página 30

Página 31

Página 32

Página 33

Página 35

Página 36

Página 37

Página 39

Página 41

Página 42

Página 43

Página 44

Página 45

Página 47

Página 48

Página 49

Página 50

Página 51

Página 52

Página 53

Página 54

Página 55

Página 56

Página 57

Página 60

Página 61

Página 63

Página 64

Página 65

Página 66

Página 67
Direita: Redesenhado de fotos em: Anuário Brasileiro da erva-mate de 1999. Editado pela Gazeta Grupo de Comunicaşões, Santa Cruz do Sul, Rio Grande do Sul, Brasil (fotos de Inor Assmann/ Agência Assmann and Sílvio Ávila)

Baseado em foto de Marianne C. Scheffer

Baseado em foto de Marianne C. Scheffer

Chamaedorea elegans, desenhado de uma amostra viva, Museu Paraense Emílio Goeldi, Belém, Brasil

Baseado em foto de César Carrillo Trueba

Baseado em foto de César Carrillo Trueba

Carludovica palmata, desenhado de uma amostra viva, Praça de Belém, Brasil

Acima: Baseado em foto de Rocío Alarcón Gallegos

Abaixo: Baseado em foto de Rocío Alarcón Gallegos

Carludovica palmata, Baseado em foto (de amostras vivas) de Rocío Alarcón Gallegos

Baseado em foto de Elaine Marshall

Baseado em foto de Elaine Marshall

Baseado em foto de Elaine Marshall

Achmea magdalenae, desenhado de um espécime botânico, Instituto de Ecología A.C. Herbarium, Xalapa, México

Acima: Baseado em foto de Elaine Marshall

Abaixo: Baseado em foto de Fabrice Edouard

Redesenhado de uma ilustração fornecida pelo autor do caso, Fabrice Edouard

Baccharis trimera, desenhado de um espécime botânico, Empresa Brasileira de Pesquisa Agropecuária (EMBRAPA), Herbário, Belém, Brasil

Baseado em foto de Walter Steenbock

Baseado em foto de Walter Steenbock

Baseado em foto de Walter Steenbock

Sabal yapa, Baseado em foto (de amostras vivas) de Javier Caballero

Baseado em foto de Carlos Martorell

Baseado em foto de Javier Caballero

Baseado em foto de María Teresa Pulido

Pimenta dioica, desenhado de um espécime botânico, Instituto de Ecología A.C. Herbarium

Acima: Baseado em foto de Myrna Mendoza Cruz

Abaixo: Baseado em foto de Francisco Basurto Peña

Pfaffia glomerata, desenhado de uma amostra viva, Empresa Brasileira de Pesquisa Agropecuária (EMBRAPA), coleção de plantas medicinais, Belém, Brasil

Baseado em foto de Cirino Corrêa Júnior

Baseado em foto de Cirino Corrêa Júnior

Psychotria ipecacuanha, desenhado de uma amostra viva, Empresa Brasileira de Pesquisa Agropecuária (EMBRAPA), coleção de plantas medicinais, Belém, Brasil

Baseado em foto de Rafael A. Ocampo Sánchez

Baseado em foto de Rafael A. Ocampo Sánchez 
Página 69

Página 70

Página 71

Página 72

Página 73

Página 74

Página 75

Página 77

Página 78

Página 79

Página 80

Página 81

Página 85

Página 86

Página 87

Página 88

Página 89

Página 92

Página 93

Página 94

Página 95

Página 96

Página 97

Página 98

Página 99

Página 101

Página 109

Página 122

Página 131

Última capa
Euterpe edulis, desenhado de uma foto de Harri Lorenzi (in Lorenzi, H. 1996 Palmeiras No Brasil: Nativas e Exóticas, Editora Plantarum Ltda.

Baseado em esbosos de Alfredo C. Fantini

Baseado em esbosos de Alfredo C. Fantini

Da esquerda para a direita: Baseado em esbosos de Alfredo C. Fantini

Carapa guianensis, desenhado de uma amostra viva, Empresa Brasileira de Pesquisa Agropecuária (EMBRAPA), coleção de plantas medicinais, Belém, Brasil

Baseado em foto de Patricia Shanley

Baseado em foto de Patricia Shanley

Bursera glabrifolia, desenhado de um espécime botânico, Instituto de Ecología A.C. Herbarium, Xalapa, México

Desenhado de uma amostra

Baseado em foto de Silvia E. Purata

Baseado em foto de Silvia E. Purata

Uncaria tomentosa, desenhado de um espécime botânico, Empresa Brasileira de Pesquisa Agropecuária (EMBRAPA), Herbário, Belém, Brasil

Trema micrantha, desenhado de um espécime botânico, Instituto de Ecología A.C. Herbarium, Xalapa, México

Desenhado de uma amostra

Baseado em foto de Citlalli López

Baseado em foto de Citlalli López

Pinus caribeae, Baseado em foto (de um espécime botânico e amostras vivas) de Ynocente Betancourt Figueras

Da esquerda para a direita: Baseado em foto de Ynocente Betancourt Figueras

Bursera aloexylon, desenhado de um espécime botânico, Instituto de Ecología A.C. Herbarium, Xalapa, México

Desenhado de uma amostra

Baseado em foto de Paul Hersch-Martínez

Baseado em foto de Paul Hersch-Martínez

Hevea brasiliensis, desenhado de uma amostra viva, Empresa Brasileira de Pesquisa Agropecuária (EMBRAPA), Belém, Brasil

Baseado em foto de Mariana Ciavatta Pantoja

Baseado em foto de Mariana Ciavatta Pantoja

Baseado em foto de Mario Pinedo Panduro

Redesenhado de uma ilustração de Anabelle Maffioli (in ANAI Serie de Boletines Técnicos para el Agricultor, Boletín Técnico no. 3, El Pejibaye, 1986)

Baseado em foto de Elaine Marshall

Baseado em foto de Patricia Shanley

Platonia insignis, desenhado de uma amostra viva, Empresa Brasileira de Pesquisa Agropecuária (EMBRAPA), Belém, Brasil 

Os capítulos deste livro contam ao mesmo tempo uma só e muitas histórias sobre o destino entrelaçado de plantas e povos da floresta.

À medida que os vínculos entre pessoas e plantas se tornam mais complexos, aumenta também a importância de reconhecermos a nossa dependência das plantas para a nossa sobrevivência e bem-estar físico, cultural e espiritual. Os leitores deste livro podem tirar importantes lições, advertências e inspiração a partir de uma grande variedade de plantas e

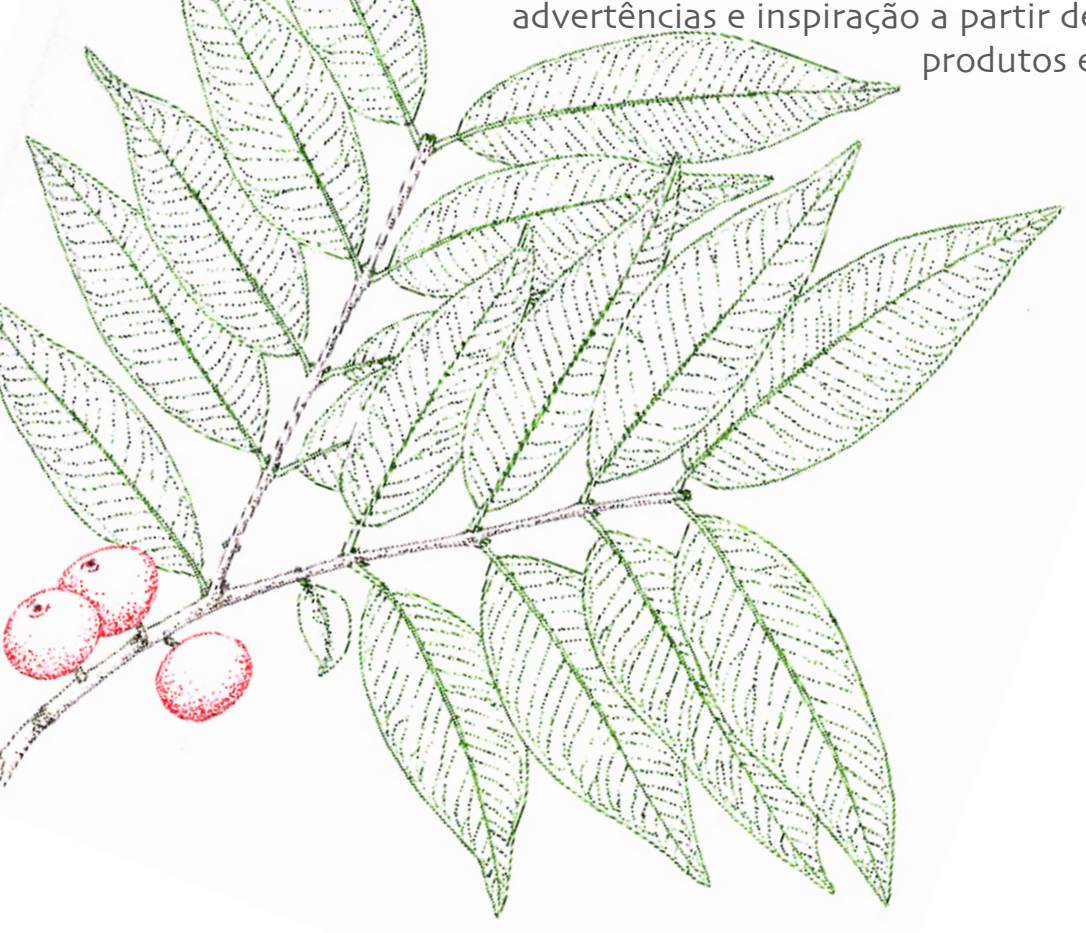

Miguel Alexiades Department of Anthropology University of Kent Cantebury, U.K.
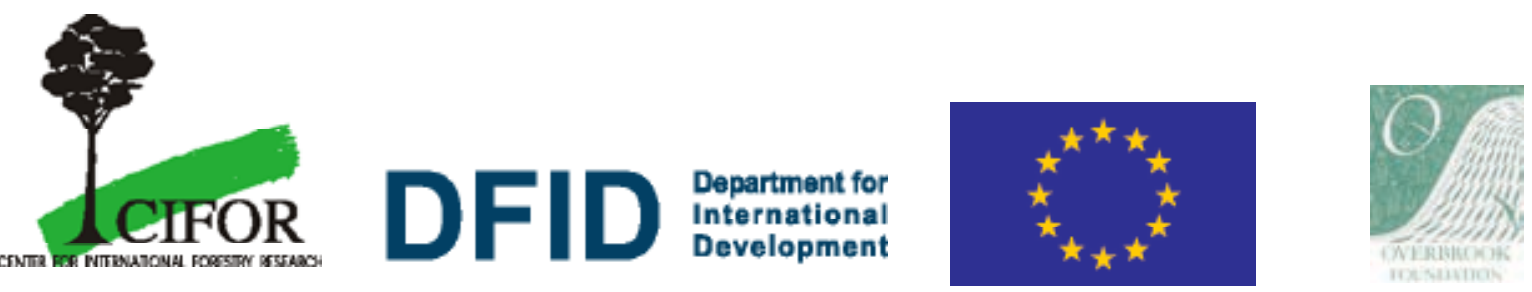